MATHIAS GLENS

\title{
ÓRFÃOS DE PAIS VIVOS: UMA ANÁLISE DA POLÍTICA PÚBLICA DE ABRIGAMENTO NO BRASIL
}

Dissertação apresentada à Faculdade de Psicologia da Universidade de São Paulo para obtenção do Título de Mestre.

SÃO PAULO 


\section{ÓRFÃOS DE PAIS VIVOS: UMA ANÁLISE DA POLÍTICA PÚBLICA DE ABRIGAMENTO NO BRASIL}

Dissertação apresentada à Faculdade de Psicologia da Universidade de São Paulo para obtenção do Título de Mestre.

Programa de Pós-Graduação em Psicologia da Aprendizagem, do Desenvolvimento e da Personalidade.

Orientador: Prof. Dr. Paulo César Endo. 
À minha avó Elda, que despertou em mim a paixão pelo conhecimento.

À minha esposa, querida companheira de todos os momentos, que hoje compartilha comigo essa paixão. 


\section{AGRADECIMENTOS}

Agradeço à Faculdade de Psicologia da Universidade de São Paulo pela oportunidade de aprendizagem e amadurecimento intelectual.

Agradeço a todos que colaboraram para a realização desta dissertação, e de forma especial ao Prof. Dr. Paulo César Endo, meu orientador no sentido mais amplo da palavra, que não desistiu desta pesquisa mesmo quando eu próprio já havia desistido.

Aos colegas do grupo de orientação em pesquisa, Paulo, Polyana, Karina, Rose, Helena, Maikel, Luís, Rafael, Lívia, Daniel e Rita, parceiros na difícil arte da escrita e da produção de conhecimento.

Aos colegas de trabalho nos abrigos de Guarulhos, que compartilharam comigo as angústias e inquietações que deram origem a este trabalho.

Aos meus pais, pelo amor que sempre me dedicaram. 


\section{RESUMO}

O objetivo desta dissertação é analisar o desenvolvimento da política pública de acolhimento institucional no Brasil atual. Para isso, inicialmente, apresenta-se um breve histórico das políticas dirigidas à infância e juventude em situação de vulnerabilidade, tendo como foco a questão da internação de crianças e adolescentes. Em seguida, abordam-se as mudanças trazidas pelo Estatuto da Criança e do Adolescente (ECA) referentes às ações e aos projetos de atendimento dirigidos a esse público. Por fim, por meio da análise de três grandes pesquisas quantitativas a respeito do tema, propõe-se um exercício de comparação entre o que está determinado em lei e nos documentos oficiais de orientação e normatização da política pública e a realidade concreta das instituições de abrigamento, tal como apontada pelas referidas pesquisas.

Palavras-chave: Abrigamento. Política Pública. Acolhimento Institucional. Crianças e Adolescentes em Situação de Vulnerabilidade Social. 


\begin{abstract}
The aim of this study is to analyze the development of the public policies of institutional care in Brazil in the present day. To do so, initially, this work presents a brief history of the policies directed to the childhood and youth under situation of vulnerability, focusing the matter of institutionalized children and adolescents. After that, the changes brought by the Children and Adolescents Code regarding the actions and projects directed to institutionalized children and adolescents are brought to discussion. Finally, analyzing three great quantitative researches regarding the subject, this work presents a comparison between what is determined by the law and the public policies official orientation documents and the reality of the residential care institutions that is shown by the above mentioned researches.
\end{abstract}

Keywords: Residential Care. Public Policy. Institutional Care. Children and Adolescents under situations of social vulnerability. 


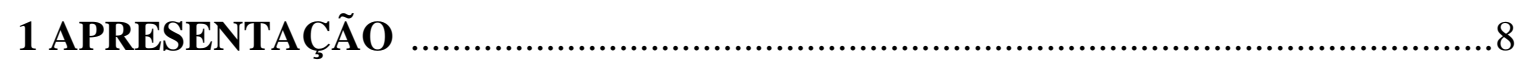

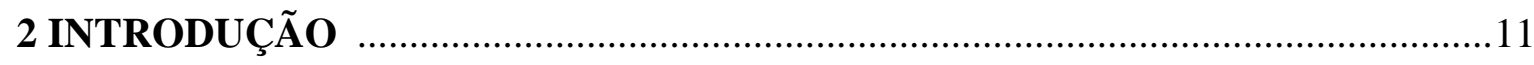

2.1 Objetivos e método …………………………………………………………....11

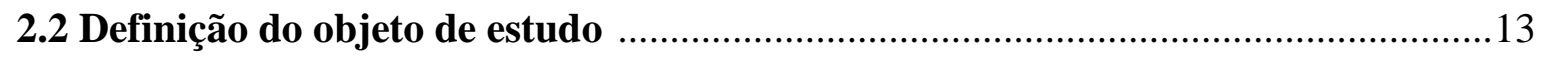

3 BREVE HISTÓRICO DOS ABRIGOS NO BRASIL ……………………………...16

4 O DIREITO À CONVIVÊNCIA FAMILIAR E COMUNITÁRIA: OS AVANÇOS DO ECA EM RELAÇÃO À MEDIDA DE ABRIGAMENTO ………………………......39

5 ANÁlise da ATUal POLítica pública de abrigamento No

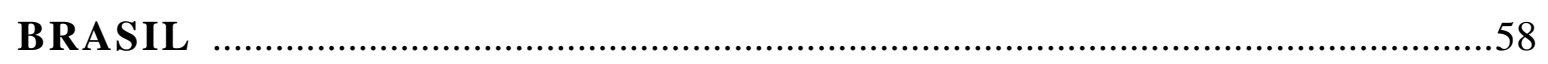

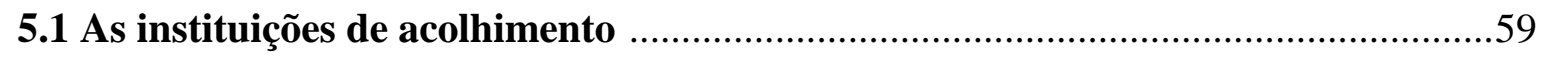

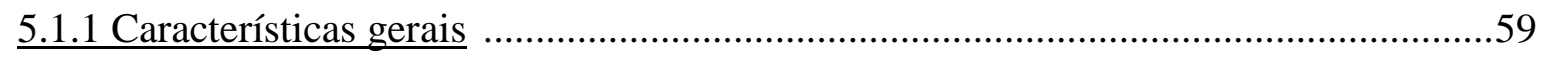

5.1.2 $\mathrm{O}$ atendimento oferecido ……………………………………………………....6

5.1.2.1 Não-especialização no atendimento, coeducação e faixa etária ampliada: três princípios contra a exclusão . .68

5.1.2.2 Modalidades e tipos de abrigos: dividir para segregar ou dividir para

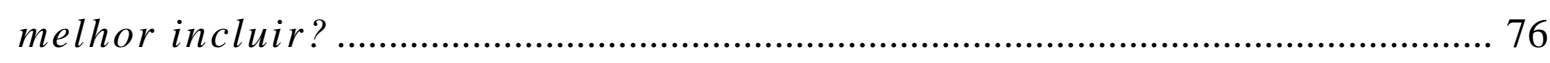

5.1.2.3 O número de vagas: um posicionamento contra o atendimento massificado .........87

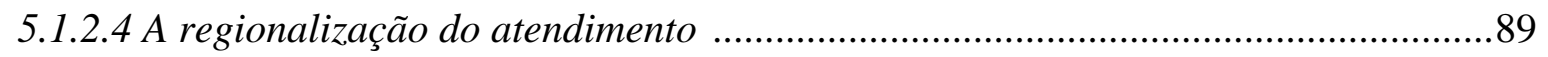

5.1.3 A relação do abrigo com a comunidade ………………………………………......93

5.1.3.1 Sob a sombra das instituiçôes totais ...................................................................93

5.1.3.2 A participação de pessoas da comunidade no processo educativo .........................97

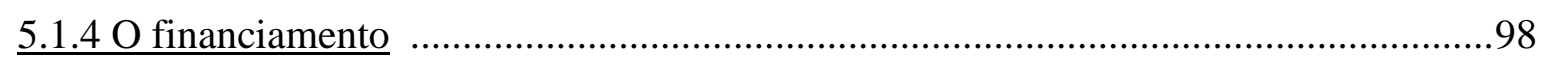

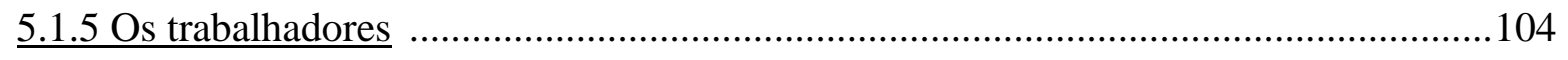

5.1.5.1 O papel de educador: um "profissional do vínculo" ................................................104

5.1.5.2 O perfil dos profissionais ................................................................................... 108

5.1.6 A preservação dos vínculos familiares ……………………………………….....122

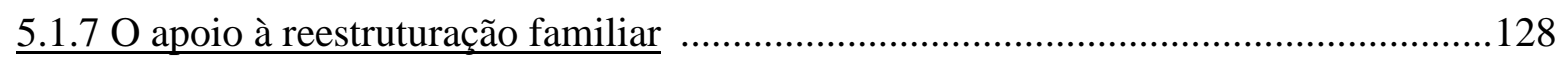

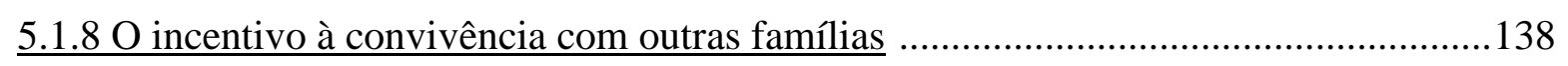

5.1.9 A organização do abrigo como uma residência …………………………………......143

5.2 A demanda das instituições de acolhimento ……………………………………....150

5.2.1 As crianças e adolescentes abrigadas ....................................................................150 
5.2.1.1 O perfil de quem vive nos abrigos: o rosto das vítimas da violência contra crianças $e$ adolescentes 150

5.2.1.2 Os motivos de abrigamento: a excepcionalidade em questão 156

5.2.1.3 O tempo de abrigamento: a provisoriedade em questão 172

5.2.1.4 Algumas características psicológicas da criança ou adolescente abrigado: esboço de uma psicodinâmica do abandono 175

5.2.2 As famílias das crianças e adolescentes abrigados .179 6 CONSIDERAÇÕES FINAIS .200

6.1 Indicativos para a política pública de proteção à criança e adolescente vítima de violência: apontamentos para próximas pesquisas ...................................................206

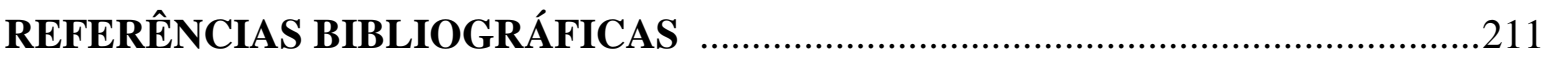




\section{APRESENTAÇÃO}

“Nem toda agressão é ódio. E nem toda alegria é felicidade." (Inscrição de uma adolescente acolhida deixada em uma das paredes do abrigo.)

O estudo da questão do abrigamento surgiu-nos a partir de um interesse profissional, uma vez que, desde 2007, venho trabalhando com essa realidade, inicialmente a partir da função de educador social na cidade de Guarulhos (São Paulo).

A descrição das tarefas e competências desse profissional é ampla, abrangendo trabalhos com idosos esquecidos ou violentados por suas famílias, geração de renda para trabalhadores pobres e desempregados, meninos e meninas em situação de rua, mulheres vítimas de violência por parte de seus maridos e erradicação do trabalho infantil.

A multidisciplinaridade também está em questão quando o assunto é educação social, já que, dentre as exigências para se candidatar ao cargo normalmente se exige o nível superior na área de psicologia, pedagogia ou serviço social.

No entanto, apesar das amplas possibilidades de ação, todos esses profissionais estavam sendo contratados para trabalhar em um único lugar: os abrigos municipais. O concurso para educadores sociais era, na realidade, uma tentativa de resposta dos gestores à época para a situação caótica em que se encontravam os abrigos da prefeitura, serviços totalmente sucateados, sem as mínimas condições de trabalho.

Era impressionante, para mim, a cada dia de trabalho, presenciar como aquelas crianças e adolescentes haviam sobrevivido a tantas dificuldades e ainda permaneciam "em pé”. Vítimas de espancamentos, abusos sexuais, estupros, abandonados, viciados em crack ou em maconha, infratores, vítimas da prostituição infantil. Foi com essa realidade dura e cruel que me deparei quando iniciei meu trabalho.

Tinha em minhas mãos uma tarefa igualmente dura: proteger, cuidar e educar essas pessoas tão surradas pela vida e que, em alguns casos, estavam dispostas a surrar a vida de volta. Foram muitos os conflitos, as angústias e as decepções. No entanto, também foram 
inúmeros os momentos de alegria e realização. Broncas, conselhos e conversas que varavam madrugada adentro e que eu, brincando, chamava de "psicanálise da meia-noite".

Inicialmente, o que mais me impressionou foi a agressividade desses meninos e meninas. Eles eram muito violentos tanto com os funcionários como uns com os outros. Uma violência que emergia, na maioria das vezes, de forma inesperada e incompreensível. Era extremamente difícil para os educadores dos abrigos entenderem os porquês dessa raiva direcionada a tudo e a todos. Para a maioria das pessoas que com eles conviviam, essa situação de violência generalizada era naturalizada por meio de discursos que creditavam a agressividade como algo inerente àquelas crianças e adolescentes.

Como educador, por meio do vínculo que consegui constituir com eles, fui percebendo que muito mais violento era o sistema de atendimento no qual eles estavam inseridos, sem mencionar os abusos sofridos no tempo antes de serem abrigados. Percebi que o passado os assolava e que as instituições que deveriam protegê-los no presente não possuíam condições mínimas para isso. Por meio das histórias que me contavam sobre suas vidas, fui me conscientizando de que a violência que atualmente expressavam também tinha uma história: a violência de hoje era fruto da violência que sofreram ontem. Socializados na linguagem da agressão, eles apenas devolviam ao mundo o que dele receberam. Meu percurso como educador social me permitiu concluir que a violência das crianças e adolescentes abrigados é, quase sempre, uma contraviolência.

Depois de cerca de um ano nessa tarefa, fui convidado a assumir a coordenação de um dos abrigos da prefeitura: a temida Casa Abrigo I. "Temida" porque era a casa para a qual, ao longo de muitos anos, eram enviados os adolescentes "mais complicados". Tal postura, fruto de uma triagem mal-feita e até preconceituosa, acabou gerando um lugar de "malditos", onde os meninos e meninas se identificavam com as imagens de "bandidos" e "perdidos" que a própria rede de abrigamento lhes impunha. Era uma espécie de profecia autorrealizadora.

Os desafios cresceram. $\mathrm{E}$ as responsabilidades também. Mas eu continuei acompanhando o dia a dia dessas crianças e adolescentes. Só que o trabalho, naquele momento, apesar das muitas semelhanças, também possuía algumas diferenças importantes.

Como educador, entrei em contato com as histórias de vida dessas crianças e adolescentes, contadas por eles mesmos. Como coordenador do abrigo, pude conhecer essas histórias, tal como registradas pelas instâncias oficiais, por seus processos e prontuários.

Comecei a ter uma visão mais ampla do que é um abrigo. Passei a me interessar não só pelas vidas daqueles que ali viviam, mas também pelo abrigo pensado como política pública, 
enxergando meu trabalho a partir do contexto maior no qual ele estava inserido. Foi quando me dei conta de que sem uma mudança nesse contexto nunca aconteceriam as mudanças que eu, como educador, tanto sonhava que se realizassem na vida daqueles meninos e meninas. A resposta para a situação caótica que encontrei no início de meu trabalho estava na concepção e na infraestrutura do serviço de acolhimento que era oferecido, o que, em larga medida, determinou o caminho que percorri ao longo desse trabalho.

Frente aos problemas que aumentavam, eu mergulhava cada vez mais em estudos e pesquisas que pudessem me auxiliar a compreender melhor aquela realidade que me envolvia.

Comecei a perceber que, além de poucos, os conhecimentos existentes estavam bastante dispersos. Foi quando se desenvolveu a ideia desse trabalho nos moldes aqui expostos: um estudo amplo e com a pretensão de congregar, em um único texto comentado, a maioria ou, pelo menos, as principais referências e estudos disponíveis sobre a política pública de abrigos. 


\section{INTRODUÇÃO}

Inicialmente, a tarefa que nos cabe é delimitar nosso tema de pesquisa, bem como os meios de que lançaremos mão para alcançarmos nossos objetivos.

\subsection{Objetivos e método}

O objetivo desta pesquisa é analisar o desenvolvimento e o grau de implementação da política pública de acolhimento institucional no Brasil. Não foi colocado como pretensão reunir o debate em torno do tema ou, ainda, fazer um estado da arte. Deseja-se, outrossim, congregar e analisar os dados e as informações disponíveis, principalmente as informações quantitativas existentes a esse respeito e, a partir delas, desenvolver reflexões próprias sobre os temas. A breve historiografia realizada no início deste estudo tem como intuito apenas contextualizar a situação atual do abrigamento no Brasil, sendo esta última o maior foco de interesse.

Está-se consciente de que a diversidade dos temas abordados muitas vezes inviabiliza um maior aprofundamento sobre cada tópico. No entanto, essa é, justamente, a opção e a especificidade do presente estudo. Apesar de considerar que nenhum dos itens abordados foi tratado de modo superficial ou leviano, este trabalho prezou pela visão da política de abrigamento de um modo mais global, arcando com as limitações dessa escolha, mas, ao mesmo tempo, acreditando firmemente que o trabalho com a política em seus múltiplos aspectos viabilizará uma compreensão importante das interações entre suas partes, bem como uma visão integradora da mesma para todos os seus trabalhadores, estudiosos e operadores.

Para concretizar esses objetivos, esta pesquisa optou por, além da retomada histórica, esboçar um amplo panorama da situação dos abrigos no Brasil, a partir do estudo detalhado e de comentários das três maiores pesquisas quantitativas de larga abrangência existentes sobre o assunto: o "Levantamento Nacional de Abrigos para Crianças e Adolescentes da Rede SAC", "Por uma política de abrigos em defesa de direitos das crianças e adolescentes na

\footnotetext{
${ }^{1}$ Serviços de Ação Continuada.
} 
cidade de São Paulo: motivos de demanda e qualidade de oferta de serviços de atenção à criança e adolescente sob medida de abrigo" e "Famílias de crianças e adolescentes abrigados: quem são, como vivem, o que pensam, o que desejam".

A primeira pesquisa, realizada pelo Instituto de Pesquisa Econômica Aplicada (IPEA) e promovida pela Secretaria Especial dos Direitos Humanos (SEDH), é, em termos quantitativos, o maior estudo desse tipo existente no Brasil e talvez a única de abrangência nacional, ainda que não se constitua em um censo exaustivo de todos os abrigos do país.

O Levantamento Nacional tem grande importância na história das instituições que acolhem crianças e adolescentes, pois, além de seu caráter pioneiro, ele vem no bojo de um movimento atual de reordenamento dos abrigos no país, que se preocupou em conhecê-los para transformá-los. Pela primeira vez, tem-se a possibilidade de visualizar de modo mais completo essa problemática.

O mesmo vale para a segunda pesquisa citada, mas com abrangência territorial menor, já que o objeto de seu estudo é a cidade de São Paulo. É uma parceria entre a Associação dos Assistentes Sociais e Psicólogos do Tribunal de Justiça do Estado de São Paulo (AASPTJ/SP), o Núcleo de Estudos e Pesquisas sobre a Criança e o Adolescente da Pontifícia Universidade Católica (NCA/PUC-SP), a Fundação Orsa e a Secretaria de Assistência Social do Município de São Paulo (SAS).

É importante salientar que nas duas pesquisas de referência citadas acima (IPEA, 2003; AASPTJ-SP/NCA-PUCSP/SAS/Fundação Orsa, 2003) foi possível perceber a tonalidade característica dos discursos oficiais, poupando o Poder Público de certas críticas possíveis de serem a ele dirigidas. Essa situação está intimamente relacionada à vinculação governamental de ambos os estudos, sem a qual, por outro lado, teria sido impossível sua realização com a abrangência pretendida. Diante de tal situação, tentou-se, nos comentários e na própria forma de apresentação dos dados, uma interpretação mais crítica da política de abrigamento.

A terceira pesquisa selecionada para servir de eixo estruturante do presente trabalho é uma parceria entre o mestrado em Políticas Sociais da Universidade Cruzeiro do Sul, a Associação de Pesquisadores de Núcleos de Estudos e Pesquisas sobre a Criança e o Adolescente (NECA) e o Núcleo da Criança e do Adolescente (NCA) da PUC-SP, sob a coordenação das professoras Eunice Teresinha Fávero, Maria Amália Faller Vitale e Myrian Veras Baptista. Também abordando a realidade da cidade de São Paulo, essa pesquisa foi selecionada para este estudo por ter a vantagem de, além de não ser uma pesquisa "oficial" no 
sentido de estar intimamente vinculada à gestão pública, traz a voz das famílias das crianças e dos adolescentes em situação de abrigamento, geralmente ausentes dos estudos e pesquisas sobre o tema, contextualizando suas falas e visões a respeito da institucionalização de seus filhos.

Essas pesquisas servirão como eixos estruturantes para as reflexões propostas neste trabalho, um grande dispositivo para colocar em contexto os achados, as críticas e os pensamentos desta pesquisa. Além disso, suas estatísticas e porcentagens funcionarão como contraponto para a análise da política pública de abrigos, na medida em que possibilitarão a comparação entre o ideal e o real, ou seja, entre o que está definido na legislação e demais marcos regulatórios e o que de fato se apresenta na realidade dessas instituições. Em outras palavras, pretende-se captar o grau de implementação da política pública de abrigamento.

A escolha dessas pesquisas como eixos norteadores da análise justifica-se pela abrangência das mesmas e pela pluralidade de dados quantitativos, importantes para os propósitos do trabalho. Através de comentários, espera-se atribuir um sentido mais vivo e concreto aos números e percentuais apresentados nos estudos citados, tentando, sempre que possível, interligar os dados sobre a política pública e os avanços e dilemas do cotidiano dos abrigos.

Nesse sentido, a estruturação da pesquisa evitou a apresentação cronológica e estanque das leis e marcos regulatórios, optando por uma organização em torno de temas. Assim, os artigos do Estatuto da Criança e do Adolescente (ECA) e as normativas dos documentos oficiais vão sendo apresentadas e discutidas na medida em que são demandados pelos temas e não da forma como estão registrados nos textos oficiais.

\subsection{Definição do objeto de estudo}

Uma vez expostos os objetivos e o método deste trabalho, segue-se a tarefa de definir o objeto de estudo. Afinal, o que é um abrigo? Para Silva e Mello (2003),

[...] no Estatuto da Criança e do Adolescente, o abrigamento em entidade é definido como uma medida de proteção. A interpretação estrita dessa definição conduz ao raciocínio de que as instituições que oferecem programas de abrigo atendem crianças e adolescentes que tenham seus 
direitos violados e que, em razão disso e pela especificidade do caso, necessitem ser temporariamente afastados da convivência com suas famílias. Funcionam, assim, como moradia alternativa até o retorno à família de origem ou até a colocação em família substituta. (IPEA, 2003, p. 37)

Os abrigos são, portanto, instituições que acolhem crianças e adolescentes que sofreram algum tipo de violência e que, por causa da violência sofrida, tiveram que ser retirados de suas famílias. Visam o atendimento de pessoas menores de 18 anos que sofreram violência intrafamiliar.

Sob uma ótica mais descritiva, a ideia de "moradia alternativa" parece dar conta da questão. No entanto, para compor uma caracterização dos abrigos, tem-se, em síntese, dois eixos em torno dos quais gira a definição desses serviços: o da violência intrafamiliar e a da separação do convívio familiar. É somente nas tensões, contradições e ambiguidades inerentes à relação desses dois eixos que se pode situar as questões relativas a essa instituição tão polêmica: a separação do convívio interrompe a violência ou revitimiza todos os envolvidos no processo? O abrigo pode efetivamente proteger ou, ao contrário, apenas contribui para a desagregação familiar? Afinal, ele é um bem? Um mal? Um mal necessário? Qual é a proteção que ele efetivamente oferece?

Todas essas questões, essenciais ao estudo dos abrigos, servirão como objetivos específicos, perpassando este trabalho em praticamente todos os momentos, não podendo ser compreendidas tomando-se em separado apenas um dos dois eixos identificados acima. Ao contrário, elas colocam-se justamente na tensão entre a violência intrafamiliar, que por si só já é sintoma de uma segregação interna à família, e a separação do convívio familiar que, por sua vez, também é uma violência.

Entretanto, durante as leituras, pôde-se perceber que, em muitas pesquisas, a questão da violência parece ficar em segundo plano. Por exemplo: “o critério principal para que uma entidade tenha sido considerada como abrigo foi o afastamento da criança ou do adolescente da convivência familiar, em tempo contínuo ou parcial" (AASPTJ-SP/NCAPUCSP/SAS/Fundação Orsa, 2003, p. 20). Quando isso acontece, não se consegue distinguir com exatidão os abrigos de instituições nos moldes de "colégios internos", serviços de ensino que têm a peculiaridade de acolher crianças e adolescentes durante a semana, sendo que, nos finais de semana ou, ainda, na época de férias, elas retornam à convivência com seus familiares. Nessas instituições, por exemplo, o eixo do afastamento se coloca claramente, mas o da violência não se impõe de modo explícito. 
O Levantamento Nacional trata simplesmente de "programa de abrigo para crianças e adolescentes em situação de risco pessoal ou social” (cf. IPEA, 2003). Tal definição é demasiadamente vaga: "situação de risco pessoal e social" abrangeria, por exemplo, a situação de pobreza, que não é um motivo de abrigamento.

Outra definição possível seria: programa de abrigo para crianças e adolescentes vítimas de violência e que, por causa da violência sofrida, tiveram que ser retiradas de suas famílias. A definição encontrada no Levantamento Nacional é ampla demais. A que propõese, no entanto, talvez exclua os abrigos que, por exemplo, recebem filhos de empregadas domésticas que são obrigadas a dormir na casa dos patrões durante a semana e só podem ficar com seus filhos nos finais de semana. Mas, por outro lado, a primeira, por ser abrangente demais, acabaria por incluir toda e qualquer criança ou adolescente pobre, já que a pobreza é, por si só, um risco social.

Em nossa opinião, é a questão da violência que traz a especificidade que caracteriza a demanda de abrigamento. Mesmo assim, ainda não estaria resolvida plenamente a questão da inclusão da pobreza entre os motivos de abrigamento, pois, para se pensar de modo ampliado, também poder-se-ia dizer que o pobre é uma vítima a priori de uma violência estrutural: a desigualdade social e a negligência do Estado frente a essa injustiça. Nesse modo ampliado de pensar, até a incorporação da questão específica da violência na definição da população que demanda uma instituição de abrigo ainda não traz a caracterização necessária para a referida população. Precisa-se especificar qual violência gera demanda de abrigamento.

Para resolver esse problema, talvez se pudesse arriscar uma diferenciação entre violência direta e violência indireta, caracterizando a segunda nos moldes expostos acima para violência advinda da desigualdade social, ou seja, o que se denomina de "violência estrutural". Desse modo, poder-se-ia afirmar que a demanda específica de abrigamento é aquela que é vítima de violência direta e, ainda, uma violência direta grave, tão grave a ponto de justificar o rompimento da convivência familiar como único meio para sua interrupção imediata.

A grande dificuldade quando se pensa em abrigos é que a violência é, ao mesmo tempo, sua causa e sua consequência: ela foi o motivo do encaminhamento, mas a própria separação familiar, essência desses serviços, é novamente uma violência. 


\section{BREVE HISTÓRICO DOS ABRIGOS NO BRASIL}

Quando se analisa a história da assistência à infância ao longo dos séculos XIX e XX no Brasil percebe-se que:

[...] as crianças nascidas em situação de pobreza e/ou em famílias com dificuldades de criarem seus filhos tinham um destino quase certo quando buscavam apoio do Estado: o de serem encaminhadas para instituições como se fossem órfãs ou abandonadas. (RIZZINI \& RIZZINI, 2004, p. 13)

Um olhar sobre a história revela que a institucionalização era o procedimento-padrão para a grande maioria dos casos relacionados à infância pobre, sendo praticamente onipresente para aqueles que buscavam auxílio oficial.

Essas instituições eram, até o final da década de 1980, denominadas "internatos de menores" ou "orfanatos" e "funcionavam nos moldes de asilos, embora as crianças, em sua quase totalidade, tivessem famílias" (RIZZINI \& RIZZINI, 2004, p. 14). Percebe-se que os orfanatos carregam em seu próprio nome a negação de que seus "internos" possuíam família. Mesmo quando as situações de orfandade e abandono não faziam parte da história de vida dessas crianças e adolescentes, uma vez dentro dessas instituições, eles eram "transformados" em órfãos e abandonados. Desenvolvendo uma política de resposta única, podemos afirmar que, sob certo aspecto, esses meninos e meninas eram realmente órfãos e abandonados: não pelos seus pais, mas sim pelo Estado.

Ironicamente, “desde os idos de 1900, a internação de crianças aparece na literatura jurídica como o último recurso a ser adotado" (RIZZINI \& RIZZINI, 2004, p. 14). O Brasil parece ter uma longa história de leis que existem somente no papel. A institucionalização "como último recurso" é um dos principais avanços do ECA na sua tentativa de superar o que Pilotti \& Rizzini (1995) denominam “cultura da institucionalização". Nesse sentido, não é sem espanto que se percebe que, ao contrário do que possa inicialmente parecer, o atual "avanço" é uma recomendação antiga. Fica-se tentado a supor que o verdadeiro passo à frente será transformar essa recomendação em realidade. É isso que se tentará avaliar ao longo deste trabalho. 
A partir da ideia de uma "cultura da institucionalização", fica claro que a "opção histórica da sociedade brasileira pelo modelo asilar de assistência à infância pobre" (RIZZINI \& RIZZINI, 2004, p. 21), ou seja, da institucionalização como mecanismo de proteção, é apenas um representante de uma escolha mais ampla da institucionalização como forma de educação e cuidados com os filhos de modo geral.

Desde o período colonial, foram sendo criados no país colégios internos, seminários, asilos, escolas de aprendizes artífices, educandários, reformatórios, dentre outras modalidades institucionais surgidas ao sabor das tendências institucionais e assistenciais de cada época. (RIZZINI \& RIZZINI, 2004, p. 22)

A institucionalização não era algo reservado somente aos pobres. Era um fenômeno que atravessava todas as classes sociais, embora com diferenças significativas. ${ }^{2}$ Ainda que, tanto em relação aos pobres como aos ricos eram as intenções educativas que subsidiavam essas práticas, no que se refere aos primeiros a motivação pedagógica inseria-se fortemente em um objetivo de controle social. A "educação" dos filhos das classes pauperizadas fornecia a justificativa ideológica para seu encarceramento nos internatos.

Não parece coincidência que o início dessa história teve como protagonistas aqueles que, "por opção", institucionalizaram suas próprias vidas: no Brasil, os padres e as freiras católicas.

As instituições para a educação de meninos surgiram no Brasil colonial com a ação educacional jesuítica, que implantou escolas elementares (de ler, escrever e contar) para crianças pequenas das aldeias indígenas e vilarejos, e criou colégios, para a formação de religiosos e instrução superior de filhos das camadas mais privilegiadas da população. Os jesuítas constituíram os principais agentes educacionais até meados do século XVIII. (RIZZINI \& RIZZINI, 2004, p. 23)

\footnotetext{
${ }^{2}$ Atualmente, parece-nos que o fenômeno específico da institucionalização perdeu um pouco de sua inserção nas classes com maior poder aquisitivo. Entretanto, sua essência permanece inalterada em novos processos que se colocam na sociedade contemporânea, já que a "terceirização" da educação e dos cuidados com os filhos apenas adquiriu novas facetas. Uma delas é a que se expressa a partir do lugar social ocupado pelas "babás" nas famílias de classes mais altas, por exemplo. Outra faceta que se poderia levantar é a massiva e imperiosa veiculação da ideia da educação como algo que deve ser restrito e apenas realizado por especialistas. Está-se referindo, por exemplo, à crescente quantidade de livros de autoajuda pedagógica do tipo “como educar seus filhos?", dirigidos a pais que não se sentem detentores do conhecimento necessário às funções educativas e que deixam de assumir um lugar de autoridade frente a seus filhos.
} 
Mencionou-se anteriormente que a educação fornecia a justificativa para o controle social. No caso da Igreja, esse controle se dava nos moldes da cristianização da população brasileira, bem como da constante busca por novos fiéis.

Mas,

[...] diante da resistência do índio à doutrina cristã, os jesuítas investiram na educação e catequese das crianças indígenas. Eram consideradas "almas menos duras", isto é, mais propensas a aceitar a doutrinação católica. No sistema de catequese eram deliberadamente afastadas de suas tribos: entre 1550 e 1553 foram criadas as "Casas de Muchachos", onde eram abrigados os "curumins" ou "meninos da terra". Essas casas eram custeadas pela Coroa Portuguesa, que também autorizava a entrega de alimentos e outros produtos. (MARICONDI, 1997)

As "Casas de Muchachos" são a pré-história dos atuais abrigos. No entanto, já era possível perceber o procedimento intencional de separação de pais e filhos a serviço dos interesses da classe dominante. A "civilização" se impôs sob a base da destruição sistemática das famílias pré-existentes no território brasileiro. Em outras palavras, pode-se afirmar que a cristianização dos índios se fez à custa do direito à convivência familiar e comunitária.

$\mathrm{Na}$ verdade, desde o início da colonização brasileira e ao longo de sua história, a destruição da família foi utilizada como forma de dominação social.

Toda a atividade do tráfico negreiro e, depois, a venda de escravos em praça pública e sua distribuição por todo país foram sempre orientadas pela prática sistemática de não colocar juntos marido e mulher, pais e filhos ou pessoas da mesma tribo e da mesma família, com o único propósito de eliminar todas as possibilidades de reorganização e de resistência dos negros. (SILVA, 1997, p. 48)

A preocupação com a instrução do povo, assim como a assistência aos "pobres e desvalidos", foram áreas delegadas pelo Estado à Igreja, e esta as desenvolvia a partir de seus próprios interesses. A educação e a assistência social são políticas que possuem em sua história a ausência do Estado como um dos elementos centrais, pelo menos até meados do século XVIII.

$\mathrm{O}$ regime de funcionamento das instituições seguia o modelo do claustro e da vida religiosa. As práticas religiosas e o restrito contato com o mundo exterior eram características fundamentais dos colégios para meninos órfãos e dos recolhimentos femininos, sendo que, no segundo caso, a clausura era imposta com mais rigor. (RIZZINI \& RIZZINI, 2004, p. 24) 
A Igreja é uma instituição sexista, ou seja, homens (padres) e mulheres (freiras) são separados e tratados de maneira completamente diferente. Tal modelo de separação e tratamento diferenciado entre os sexos migrou para os internatos que eles coordenavam.

$\mathrm{Na}$ realidade, são muitos os exemplos de práticas que se deslocaram do mundo religioso para o campo educacional e de assistência à infância. Talvez o mais importante deles seja a própria opção pelas instituições fechadas.

É nesse sentido que se pode compreender uma das modalidades mais características do atendimento à infância pobre: o sistema das Rodas dos Expostos. "Surgido no período colonial por iniciativa da Santa Casa de Misericórdia e somente extinto na República" (RIZZINI \& RIZZINI, 2004, p. 24), tinha como característica manter no anonimato o autor do abandono. Em outras palavras, tal modelo, em si mesmo, desvalorizava a convivência familiar, incentivando a desresponsabilização dos pais em relação a seus filhos.

Silva (1997) denomina o período de 1500 até 1874 de fase filantrópica do pensamento assistencial brasileiro sobre a infância e adolescência, caracterizado principalmente pela implantação do modelo português, centralizado nas santas casas de misericórdia, no qual o sistema de rodas é o seu maior símbolo. "Não havia a prática da internação de crianças por tempo prolongado, sendo elas encaminhadas para famílias beneméritas, que as criavam e as mantinham como agregadas" (p. 34). Em outras palavras, as grandes famílias extensas e patriarcais, características desse momento histórico, absorviam uma parcela significativa dos abandonados da sociedade colonial como seus agregados. Segundo Mesgraves (1976 apud SILVA, 1997, p. 41), além do poder econômico e dos privilégios políticos, o senhor colonial detinha também o poder militar e a responsabilidade de defender a colônia. Assim, tanto para as atividades rurais como para os serviços de guerra, o latifundiário beneficiava-se ao manter sob seus domínios um grande número de dependentes.

Desse modo, percebe-se que um sistema como o das rodas era profícuo em alimentar esse modo de produção. Além disso, ele parece estar intrinsecamente vinculado aos valores morais da época de seu surgimento no que se refere às relações familiares, ou seja, um sistema como o das rodas é essencial para dar conta de uma figura indesejada socialmente, que eram os filhos ilegítimos. Com a instituição do matrimônio como algo sagrado e o peso dos valores conservadores sobre as relações sexuais, um modelo que permitia manter no anonimato aqueles que fracassavam no cumprimento de tais exigências sociais era extremamente interessante. 
A Roda dos Expostos também foi muito utilizada por famílias pobres, que abandonavam seus filhos por considerarem que não possuíam condições de criá-los. Em outras palavras, tal modelo de atendimento era utilizado como forma de enfretamento da pobreza. Inicia-se, aqui, uma trajetória de atuar nas consequências (o abandono) de um problema (a pobreza) ao invés de combater suas causas que chegará até os dias atuais como uma questão para a política de proteção à criança e ao adolescente.

Além disso, "a criação coletiva de crianças pequenas nas Casas de Expostos, em um período anterior às descobertas de Pasteur e da microbiologia, resultava em altíssimas taxas de mortalidade" (RIZZINI \& RIZZINI, 2004, p. 23), chegando a índices de mortalidade que giravam em torno de $90 \%$ (cf. SILVA, 1997, p. 37).

"Muitas Rodas de Expostos surgiram no Brasil quando na Europa estavam sendo combatidas pelos higienistas e reformadores, pela alta mortalidade e pela suspeita de fomentar o abandono de crianças" (RIZZINI \& RIZZINI, 2004, p. 24).

Ainda que essa

[...] discussão não fosse desconhecida no Brasil, foi somente no século XX, com o processo de organização da assistência à infância no país e pela interferência da ação normativa do Estado, que o atendimento aos abandonados sofreria mudanças significativas. (RIZZINI \& RIZZINI, 2004, p. 24)

Silva (1997) identifica a passagem do século XIX para o século XX (1874-1922) como o segundo período do pensamento assistencial dirigido ao atendimento da criança e do adolescente órfão ou abandonado, cuja especificidade é justamente o início da ação estatal nesse campo, especialmente na veiculação das políticas higienistas em voga na época. "Nesse período deu-se a supremacia do médico sobre o jurista no tratamento dos assuntos referentes ao amparo da criança” (p. 35).

É possível atribuir ao higienismo a acentuação da política de afastamento e isolamento dos internatos dos centros urbanos, como uma tentativa de controle de doenças (cf. SILVA, 1997, p. 42-43), mentalidade que permanece até os dias atuais no senso comum sobre abrigos.

Além disso, a partir do final do século XIX, o Estado passa paulatinamente a participar da questão do cuidado aos abandonados preocupado com os mesmos interesses que lhe moviam no questionamento do domínio católico no campo educacional: questiona-se o ensino religioso em detrimento do ensino "útil a si e à Pátria" (cf. RIZZINI \& RIZZINI, 2004, 
p. 24). Assumir as políticas dirigidas à infância, fragilizando o poder da Igreja Católica, é politicamente importante ao Estado brasileiro em sua tarefa de se afirmar como República.

Especialmente nos estabelecimentos governamentais masculinos, a ênfase passa a ser a instrução elementar e de ofícios mecânicos ao invés da instrução religiosa, apesar desta última nunca ter deixado de fazer parte dos programas educacionais.

$\mathrm{Na}$ realidade, reproduzindo a mentalidade sexista da época, essa inserção estatal inicialmente limitou-se aos meninos. "As meninas órfãs e desvalidas dos séculos XVIII e XIX podiam contar com a proteção dos recolhimentos femininos, criados por religiosos" (Ibid., p. 25). Aqui também é possível perceber que as instituições e os modelos de atendimentos apenas reproduziam os preconceitos sociais mais amplos. Ao homem, entendido como naturalmente pertencente ao mundo do trabalho, foram criadas escolas com ensino profissionalizante. Além disso, era essencial ao Brasil, que iniciava sua industrialização, garantir a formação de mão de obra. Às mulheres, destinadas ao mundo doméstico, eram necessárias instituições que garantissem às meninas, no futuro, o lugar social mais valorizado para as mulheres: um bom casamento, através do dote.

O asilo substitui a tutela do pai, oferecendo os meios necessários para as futuras mães de família reproduzirem na sociedade, tais como a educação para o lar, o enxoval de casamento e o dote. O moço interessado em casar-se podia escolher a órfã e devia ser aceito pela direção da instituição ou pelo presidente da província quando o dote era pago pelo governo. (RIZZINI \& RIZZINI, 2004, p. 26)

Essas instituições serviam como mecanismos de reprodução do lugar inferiorizado da mulher. No entanto, não eram todas as meninas órfãs que estavam destinadas a esse tipo de tratamento especial.

As irmandades e ordens religiosas que planejaram e fundaram tais instituições não se esqueceram das indigentes, as filhas naturais de mães pobres ou órfãs desvalidas. Asilos foram criados para acolhê-las, inicialmente separados dos recolhimentos para órfãs legítimas. (RIZZINI \& RIZZINI, 2004, p. 26)

O divisor social que concedia legitimidade às crianças era serem filhos concebidos em regime de matrimônio. O modo como eram concebidas era determinante do tipo de proteção que "mereciam". Para diferentes tipos de concepção, diferentes tipos de proteção. Sob o mesmo processo de exclusão social estavam submetidas as meninas negras, as quais foram 
destinadas a internatos especialmente constituídos para elas. Por meio dos sistemas de proteção que inventaram, fica claro que o Estado e a Igreja só se interessavam por tipos específicos de crianças.

"Cada categoria ocupando seus espaços físicos e sociais, de acordo com a rígida hierarquia social da época, com suas distinções entre livres e escravos, brancos e negros, homens e mulheres" (RIZZINI \& RIZZINI, 2004, p. 27).

As segregações sociais foram transformadas em segregações espaciais. A subdivisão da demanda que batia às portas das instituições era reflexo do modo como a desigualdade estava organizada socialmente. Os internatos se caracterizam como lugares de reprodução do status quo. ${ }^{3}$

No fim do século XIX, a problemática da infância se configura da seguinte maneira:

[...] se a grande questão do Império brasileiro repousou na ilustração do povo, sob a perspectiva da formação da força de trabalho, da colonização do país e da contenção das massas desvalidas, no período republicano a tônica centrou-se na identificação e no estudo das categorias necessitadas de proteção e reforma, visando ao melhor aparelhamento institucional capaz de "salvar" a infância brasileira no século XX. (RIZZINI \& RIZZINI, 2004, p. 28)

Imbuído da meta de construção da nação republicana, esse é um período de forte presença do Estado nas políticas de atenção à infância, tanto em seu planejamento como em sua implementação.

Os meios especializados cobravam dos poderes públicos a centralização da assistência, acusada de não passar de uma "caridade oficial", sem uma orientação unificada e dentro dos moldes preconizados pelos avanços das ciências. (RIZZINI \& RIZZINI, 2004, p. 29)

É a partir desses "estudos" e categorizações que se molda o conceito de "menor". A categoria que mais nos interessa nesse estudo é a de "menor abandonado", "definida tanto pela ausência dos pais quanto pela incapacidade da família de oferecer condições apropriadas de vida à sua prole” (RIZZINI \& RIZZINI, 2004, p. 29). Ou seja, a resposta que o Estado

\footnotetext{
${ }^{3}$ Um dos objetivos desse trabalho é dirigir essa mesma pergunta aos atuais abrigos: são possibilidades de emancipação ou são os mesmos instrumentos de reprodução da desigualdade social, apenas com uma nova roupagem? Tentar-se-á responder a essas perguntas com os subsídios desenvolvidos em "Análise da atual política pública de abrigamento no Brasil’”.
} 
começava a ensaiar para a questão das crianças abandonadas, que começavam a crescer exponencialmente nas cidades brasileiras, era a culpabilização de suas famílias.

As discussões em torno das práticas de institucionalização e do abandono de filhos estavam intrinsecamente associadas ao debate a respeito dos direitos reprodutivos e das concepções construídas historicamente sobre a família.

As conceitualizações sobre as famílias pobres sempre foram tributárias do que poderíamos denominar de "teoria do desvio":

[...] a noção de desvio decorre da presunção de ser o modelo de família nuclear o padrão por excelência de organização familiar e social que, no Brasil, sempre coexistiu com modelos de organização familiar próprios das comunidades indígenas preexistentes e também com modelos de organização familiar e tribal dos negros africanos. (SILVA, 2003, p. 289)

O fato é que essa convivência entre os diferentes modelos de organização familiar nem sempre foi harmoniosa, existindo não somente uma diferenciação de bases étnicas, como aponta a citação acima, mas também uma segregação de bases sociais, ou seja, idealizações e preconceitos entre as diferenças de ricos e pobres.

Foi com a edição do Código Civil Brasileiro de 1916 que o modelo de família nuclear encontrou sua legitimação jurídica, deixando claro que o lugar da mulher e dos filhos só se sustentava socialmente a partir da instituição do casamento.

\footnotetext{
A imposição da obrigatoriedade do exercício dos direitos reprodutivos apenas no âmbito do casamento transformou em tipos jurídicos os tipos sociológicos já existentes na cultura familiar brasileira, institucionalizando as figuras da mãe solteira, da concubina, da amante e do filho ilegítimo, constituindo então base para um processo de discriminação social que classifica homens, mulheres e filhos a partir da forma como se organizam socialmente e de como são gerados. (SILVA, 2003, p. 289)
}

Para essa sociedade, a forma como as crianças eram geradas parecia configurar uma espécie de marca moral, a qual o filho era condenado eternamente a carregar. No caso das concepções realizadas fora dos parâmetros idealizados da família nuclear, os filhos pareciam herdar uma dívida originada na amoralidade dos atos de seus pais. Era como se uma origem "desviante" determinasse todo o percurso posterior do indivíduo. 
No entanto, essa mesma sociedade também se esmerou em criar mecanismos para tentar "consertar" aqueles que ela própria concebeu como "anormais". A internação tinha esse objetivo latente.

Como consequência desse objetivo reformatório, é importante se atentar para outro aspecto dessa história. No início do século XX, internação e adoção dirigiram-se a tipos diferentes de crianças carentes e abandonadas.

Em relação às práticas de internação, tem-se visto que elas foram historicamente praticadas no Brasil,

[...] não como medida transitória, de caráter reparatório, com o objetivo final de restituir a normalidade da organização familiar, mas como medida definitiva, excludente e corroboradora da situação de desvio sociofamiliar. Isso ocorreu, sobretudo, em virtude do perfil da criança abrigada - afrodescendente e masculina - incompatível com o modelo de família patriarcal fomentado pelo Código Civil Brasileiro. (SILVA, 2003, p. 290)

Assim, vê-se que ao modelo de família nuclear se agregam outros preconceitos, como $o$ de gênero e, principalmente, o racial. $O$ internato era o lugar que a sociedade reservava principalmente aos meninos negros que foram abandonados por suas famílias. Já as meninas brancas, por exemplo, muitas vezes recebiam outro tipo de tratamento, sendo prioritariamente destinadas às famílias substitutas.

O caso em que o reenquadramento da criança ao modelo de família nuclear pode restituir a ela a situação de normalidade sociofamiliar configurou-se pela adoção, especialmente, de meninas brancas e recém-nascidas, mais adequado ao perfil da família padrão. Meninas e meninos afro-descendentes foram e ainda são condenados a viver em abrigos até a maioridade, assumindo o abrigo a função de um substituto para a família. (SILVA, 2003, p. 290)

A adoção era uma prática principalmente destinada àquelas crianças que podiam facilmente se adequar, por suas características físicas, aos preconceitos vigentes. Era a medida para os pobres que podiam se passar por ricos, "apagando" sua origem. Aos pobres que não se camuflavam entre a elite branca, era-lhes reservada a internação. Eram escondidos do mundo. Em resumo: às crianças pobres e brancas existia a possibilidade de adoção, principalmente às meninas. Às pobres e negras, o internato era a medida costumeiramente adotada, principalmente quando se travava de meninos. 
Com a aprovação do Código de Menores em 1927, o Estado criava não só outra instância jurídica que denegria a imagem das famílias pobres, responsável pela chamada Doutrina do Direito do Menor, mas também um sistema de assistência social e proteção à criança e ao adolescente abandonados.

[...] consagrou um sistema dual no atendimento à criança, atuando especificamente sobre os chamados efeitos da ausência [...]. Os chamados direitos civis, entendidos como os direitos pertinentes à criança inserida em uma família padrão, em moldes socialmente aceitáveis, continuaram merecendo a proteção do Código Civil Brasileiro, sem alterações substanciais. (SILVA, 2003, p. 291)

Dois códigos para duas crianças concebidas de modos muito diferentes. Dependendo de seu passado, algumas crianças possuíam um futuro e outras, não. As razões para se passar da jurisdição do Código Civil para o Código de Menores giravam em torno tanto do descumprimento das obrigações estipuladas aos pais como de conduta antissocial da própria criança ou adolescente.

A aprovação do primeiro Código de Menores é a principal realização de uma nova fase no pensamento assistencial brasileiro sobre a infância. Denominada por Silva (1997) de período assistencial (1924-1964), essa fase tem como suas principais características, além da aprovação do referido Código, a desativação da maioria das Casas dos Expostos, criação do Juizado de Menores, com forte hegemonia do Poder Judiciário no trato das questões da infância e definição legal do Estado como responsável pela tutela da criança ou adolescente órfão ou abandonado. Nesse momento "diminui sensivelmente o abandono anônimo e a mortalidade dos expostos, mas acentua-se a tutela sobre o exposto até os 18 anos de idade" ( $p$. $35)$.

Pode-se apontar, nas próprias palavras utilizadas no Código de Menores para caracterizar seu público, os sintomas de sua concepção moralista e individualizante:

O Código de Menores denominou essas crianças de expostas (menores de sete anos), abandonadas (as menores de 18 anos), vadias (os atuais meninos de rua), mendigas (as que pedem esmolas ou vendem coisas nas ruas) e libertinas (que freqüentam prostíbulos). (SILVA, 2003, p. 291)

São palavras preconceituosas porque atribuem intenção àqueles que pretendem caracterizar, afirmando que uma criança apresenta determinada conduta (vadiagem, 
libertinagem, mendicância etc.) simplesmente porque assim o deseja. A condição social assim reduzida às motivações e inclinações de ordem pessoal é característica não apenas desse conjunto jurídico, mas de toda uma pseudociência social, fortemente influenciada pela psicologia positivista, que buscou, no fim do século XIX e início do XX, explicar as diferenças sociais (a existência de pobres e ricos, por exemplo) reduzindo-as a características supostamente inerentes a cada indivíduo.

Outra característica do sistema inaugurado pelo Código de Menores de 1927 é a centralização.

O Juízo de Menores, na pessoa de Mello Matos, estruturou um modelo de atuação que se manteria ao longo da história da assistência pública no país até meados da década de 1980, funcionamento como um órgão centralizador do atendimento oficial ao menor no Distrito Federal. (RIZZINI \& RIZZINI, 2004, p. 29)

O juiz concentrava tantos poderes que, de fato, extrapolava o campo judiciário, acumulando também funções executivas e legislativas.

Pelo seu artigo 55, o Código de 1927 conferiu ao juiz plenos poderes para devolver a criança aos pais, colocá-la sob a guarda de outra família, determinar-lhe o abrigamento até os 18 anos de idade e determinar qualquer outra medida que julgasse conveniente. (SILVA, 2003, p. 292)

O destino de muitas famílias pobres era colocado nas mãos de um homem que pouco sabia a respeito de suas mazelas e dificuldades. O juiz era sempre um filho da elite, herdeiro de uma visão preconceituosa a respeito das camadas mais pauperizadas da sociedade. E, no entanto, era essa figura distante e com um olhar descontextualizado que era chamada para decidir a respeito das vidas dessas pessoas.

O juízo tinha diversas funções relativas à vigilância, regulamentação e intervenção direta sobre esta parcela da população, mas é a internação de menores abandonados e delinquentes que atraiu a atenção [...] abrindo espaço para diversas matérias [na imprensa] em sua defesa, o que, sem dúvida, contribuiu para a disseminação e aceitação do modelo. (RIZZINI \& RIZZINI, 2004, p. 29)

Parece que o modelo que se identificou nos séculos anteriores e que se denominou de "resposta única" insiste em se perpetuar ao longo do século XX. Além disso, percebe-se que 
em muitas situações os "abandonados" e os "delinquentes" eram internados nas mesmas instituições, imprimindo a esse sistema outra característica importante que se poderia denominar de indiferenciação da demanda.

Misturada com a problemática da delinquência infantil, o abandono de crianças passou por um período de extrema influência de práticas policialescas.

Em poucos anos, esse sistema saturou-se, pois não chegou a dar conta da demanda que ele próprio criou. Os juízes não conseguiam internar todos os casos que chegavam às suas mãos, a despeito de não recusarem a internação de crianças retiradas das ruas. (RIZZINI \& RIZZINI, 2004, p. 30)

Assistia-se a uma associação entre criminalidade e abandono. O termo "menor" designava indistintamente "abandonados" e "delinquentes", sendo não uma categoria linguística mais ampla que abarcava os casos, mas, de fato, uma denominação que promovia a indiferenciação deliberada entre os dois casos. Isso porque o "abandonado" passa a visto como perigoso em potencial, um futuro delinquente.

"Nesse período, a infância abandonada era entendida pelos juristas simplesmente como um caso de polícia e de repressão urbana" (MARICONDI, 1997). A partir do se identifica como criminalização do abandono não de se estranhar que as instituições dirigidas ao atendimento a essa população tivesse como inspiração o modelo prisional.

Outro dos artigos mais sintomáticos das concepções subjacentes ao Código de 1927 é o artigo 48, que

[...] estabeleceu que passados 30 dias após a notificação do recolhimento da criança sem que o pai, a mãe ou tutores se manifestassem, qualquer pessoa idônea podia requerer diante do juiz os direitos de pátrio poder sobre a criança. (SILVA, 2003, p. 292, grifo nosso)

Sem levar em consideração a questão do vínculo e do afeto, a criança mais parecia um objeto, sem vontade própria nem direito de ficar onde ou com quem fosse mais adequado a ela, e não aos adultos. Pode-se perceber na história dos direitos de crianças e adolescentes um "adultocentrismo" exacerbado, ou seja, os interesses que estavam em jogo eram quase sempre o dos adultos, e não o das crianças.

O estudo do período "menorista" de assistência à infância levanta algumas peculiaridades da ação do Estado na área. 
Se no século XIX, o silêncio era a tônica predominante em relação à família, e mesmo com relação ao educando, ao menor - cujas designações já pretendiam dizer o suficiente - com a consolidação da assistência oficial, famílias e menores estarão exaustivamente inseridos nas práticas discursivas das instituições produtoras de saberes sobre essa população. (RIZZINI \& RIZZINI, 2004, p. 30)

No período em que o Estado se ausentava das políticas de assistência à infância, o esquecimento daqueles que eram internados era a melhor consequência que o modelo desenvolvido pela Igreja poderia gerar. No entanto, conforme a presença estatal aumentava, ou seja, passava a ser o próprio Estado o responsável pela internação das crianças e adolescentes, ele necessitou construir justificativas para suas ações.

Trata-se de um esforço de construção de saberes que tentam dar conta das causas da delinquência e do abandono de crianças, dos comportamentos dos menores e das famílias, além de dar publicidade às ações institucionais e justificar ideologicamente a necessidade de intervenção junto a esse grupo social. (RIZZINI \& RIZZINI, 2004, p. 30)

Para dar conta desses propósitos, foram incorporadas à prática assistencial as contribuições de ciências como a psiquiatria, a psicologia e a medicina higienista.

A produção discursiva de todo o período de forte presença do Estado no internamento de menores é fascinante pelo grau de certeza científica com que as famílias populares e seus filhos eram rotulados de incapazes, insensiveis e uma infinidade de outros rótulos. (RIZZINI \& RIZZINI, 2004, p. 31)

Essas ciências foram utilizadas para culpabilizar a demanda ao invés de questionarem o serviço que o Estado estava oferecendo. Tornaram-se os instrumentos estatais de convencimento da população e de si mesmo em relação às políticas que desenvolvia. Criaramse "políticas sociais especiais destinadas às crianças e adolescentes provenientes de famílias desestruturadas, com o intuito de reduzir a delinquência e a criminalidade" (PASSETTI, 2008, p. 348). O abandono era visto como causa da delinquência. Seguindo esse raciocínio, se o Estado desejava prevenir a delinquência, bastava intervir no abandonado. Nesse sentido, o encarceramento de milhares de crianças e adolescentes órfãs, abandonadas ou simplesmente pobres nos internatos, ou seja, de todos aqueles que não pertenciam a uma família tida como ideal, passou a ser "cientificamente" legitimado como medida preventiva à criminalidade. 
Segundo Passetti (2008), as políticas concebem a criança pobre como potencialmente perigosa. Nesse sentido, o objetivo do Estado é retirá-la da vida delinquencial utilizando-se de instituições que visam incutir a obediência, domesticando as individualidades e garantindo assim os preceitos de uma prevenção geral (cf. p. 355). Nas palavras de Garcia Mendez e Costa (1994), “a preservação da integridade das crianças está subordinada ao objetivo de proteção da sociedade contra os futuros delinqüentes" (p. 17).

No entanto, apesar da grande quantidade de informações produzidas no período, "os dados relativos à internação de desvalidos são exíguos; o interesse investigativo repousava quase totalmente nos tidos por delinquientes" (RIZZINI \& RIZZINI, 2004, p. 31). A indiferenciação da demanda permanece, ou seja, não se consegue pensar na especificidade de cada caso.

Em 1941, o governo ditatorial de Getúlio Vargas, em resposta aos almejos de uma assistência à infância verdadeiramente centralizada, criou o SAM (Serviço de Assistência a Menores).

Instalado o SAM, o esforço de identificar os problemas e carências das instituições volta-se para o menor e sua família. As dificuldade de viabilizar as propostas educacionais do Serviço são depositadas no assistido, considerado "incapaz", "sub-normal de inteligência e de afetividade", e sua "agressividade", superestimada". (RIZZINI \& RIZZINI, 2004, p. 33)

Na realidade, o SAM apenas herda e amplia o modelo e a estrutura de atendimento dos Juízos de Menores criados a partir do Código de Menores de 1927, acrescentando-se o objetivo de se tornar um órgão de real alcance nacional.

No entanto, tal meta

[...] revelou-se um fiasco [...]. Os escritórios instalados tornaram-se cabides de empregos para "afilhados políticos" [...]. No processo de "expansão nacional" do SAM, a finalidade de assistir aos "autênticos desvalidos", ou seja, àqueles sem responsáveis por suas vidas, foi desvirtuada, sendo o órgão tomado pelas relações clientelistas, pelo uso privativo de uma instituição pública. "Falsos desvalidos", cujas famílias tinham recursos, eram internados nos melhores educandários mantidos pelo Serviço, através de pistolão e até corrupção. (RIZZINI \& RIZZINI, 2004, p. 34)

Órgãos tão grandes são de difícil fiscalização. No entanto, 
[...] foi em relação aos chamados transviados que o SAM fez fama, acusado de fabricar criminosos. [...] o órgão federal frequientou as páginas de jornais e revistas anunciando os escândalos que ocorriam por detrás dos muros de seus internos. (RIZZINI \& RIZZINI, 2004, p. 34)

Agressões, violência, corrupção e clientelismo fizeram os internatos de SAM passar a ser conhecidos como "sucursais do inferno".

Ao escolher políticas de internação para crianças e adolescentes abandonadas e infratoras, o Estado escolhe educar pelo medo. Absolutiza a autoridade de seus funcionários, vigia comportamentos a partir de uma idealização de atitudes, cria a impessoalidade para a criança e o jovem vestindo-o uniformemente e estabelece rígidas rotinas de atividades, higiene, alimentação, vestuário, ofício, lazer e repouso. Mas neste elogio à disciplina nada funciona primorosamente. Antes mesmo do dia terminar, todo o proibido já está em funcionamento articulando internos entre si, internos e seus superiores, superiores e familiares dos prisioneiros numa engenhosa economia da ilegalidade pela qual circulam mercadorias roubadas, corpos, drogas e lucros. (PASSETTI, 2008, p. 356)

Desde meados da década de 1950 já havia se iniciado um movimento de pessoas que condenavam o SAM e propunham a criação de uma nova instituição. Em 1964 surgiu a Fundação Nacional de Bem-Estar do Menor (FUNABEM).

As propostas que surgem para a instauração de um novo órgão nacional centram-se na autonomia financeira e administrativa da instituição e na rejeição aos "depósitos de menores", nos quais se transformaram os internatos para crianças e adolescentes das camadas populares. (RIZZINI \& RIZZINI, 2004, p. 35) ${ }^{4}$

A criação da FUNABEM marcou o início de nova fase no pensamento assistencial brasileiro, que Silva (1997) denomina de institucional pós-64 (1964-1990). Além dela, criaram-se também as FEBEMs no nível estadual e o espírito da Doutrina da Segurança Nacional tomou conta da área da infância e juventude. Além do Código de Menores de 1979, a introdução da disciplina militar dentro dos internatos e o encaminhamento dos ex-menores para o serviço militar e trabalho em órgãos públicos foram características marcantes dessa fase (cf. SILVA, 1997, p. 35).

\footnotetext{
${ }^{4}$ Ao longo deste trabalho, essa crítica feita ao SAM será retomada como uma questão para os abrigos atuais, indagando se, na entrada do século XXI, tais "depósitos" já foram superados.
} 
A FUNABEM nasceu com "boas intenções". Foi com ela que se iniciaram algumas características no sistema de atendimento que serão retomadas e ampliadas na década de 1990, a partir do ECA.

A tônica era a da valorização da vida familiar e da "integração do menor na comunidade". O mote "internar em último caso" figuraria com insistência na produção discursiva da instituição. Como órgão normativo, o seu objetivo não era o atendimento direto. $\mathrm{O}$ planejamento e a coordenação da ação assistencial e do estudo do menor eram a sua missão. (RIZZINI \& RIZZINI, 2004, p. 36)

No entanto, apesar dos avanços no campo propositivo, as mudanças esperadas não aconteceram. A FUNABEM, assim como as FEBEMs, herdaram do órgão antecessor toda a infraestrutura física e, sobretudo, os recursos humanos e sua cultura organizacional. "A despeito da política explícita da não internação, o grande modelo difundido no período foi o internato de menores" (RIZZINI \& RIZZINI, 2004, p. 37). Além disso, "a antiga prática do recolhimento de crianças das ruas foi intensificada" (RIZZINI \& RIZZINI, 2004, p. 37), afinal, estava-se em tempos de ditadura militar e a "limpeza" das ruas, protegendo as crianças da ameaça "subversiva", era importante fator de propaganda do regime.

Os estudos e estatísticas produzidos pela FUNABEM também tomaram esse rumo:

[...] está claro que os números desempenham um papel determinado nos textos publicados pela FUNABEM: o de valorizar a ação da instituição pela demonstração da gravidade do "problema". Milhares de necessitados requerem ações grandiosas, capazes de serem propagandeadas e de justificar a manutenção das instituições e suas equipes. (RIZZINI \& RIZZINI, 2004, p. 37)

Bem ao gosto da propaganda militar, desejosa de grandes feitos, mesmo que estes apenas mascarassem os problemas, alguns estados, como São Paulo, por exemplo, adotaram uma política de

[...] exílio para o interior dos menores da capital, agravando a "problemática da internação", ao afastar o menor da família [...] [Tal situação] revela uma política deliberada não só de "limpar" as ruas da cidade dos elementos indesejáveis, mas de punição, pelo afastamento familiar e de desarticulação, ao retirá-los de seu meio social. (RIZZINI \& RIZZINI, 2004, p. 38) 
Fica claro que a desregionalização do atendimento nos internatos agrega uma característica à política de proteção, que a transforma em algo bastante ambivalente: não se sabe ao certo se se está protegendo ou punindo essas crianças e esses adolescentes.

O exemplo da desregionalização é convincente, mas ampliando nosso olhar, toda a história da assistência à infância abandonada nos faz pensar o quanto os conceitos de proteção e punição estão intimamente misturados, sendo impossível separá-los.

Segundo Garcia Mendez \& Costa (1994), "não se fala mais em política social como um fim em si, mas como um meio para atingir outras finalidades. $\mathrm{O}$ atendimento às necessidades sociais passa a ser feito em nome dos efeitos econômicos ou da racionalidade tecnocrática (p. 126).

Em termos da política pública, ainda segundo os autores supracitados, esse período é especialmente marcado pela ocorrência de paralelismos, desperdícios, superposição e mesmo antagonismos entre programas de origens diversas, centralismo burocrático, transformando estados e municípios em executores de programas sobre os quais não tinham qualquer poder de decisão, claro sentido de controle social das políticas sociais do governo, não-coincidência entre a pauta de prioridades do Estado e as necessidades objetivas das comunidades pobres, desuniformidade de critérios na distribuição de verbas, baseados essencialmente em jogos políticos e de interesse etc. (cf. p. 127).

\begin{abstract}
O enfoque correcional-repressivo, eu via o menino como ameaça social, é substituído pelo enfoque assistencialista, que passa a percebê-lo como um carente. Assim, a noção de periculosidade cede espaço central na estratégia de atendimento para a noção de privação. $\mathrm{O}$ assistencialismo dirige-se à criança e ao jovem perguntando o que ele não é, pelo que ele não sabe, pelo que ele não tem, pelo que ele não é capaz. Daí que, comparado ao menino de classe média, tomado como padrão de normalidade, o menor marginalizado para a ser visto como carente bio-psico-social, ou seja, um feixe de carências. (GARCIA MENDEZ \& COSTA, 1994, p. 128)
\end{abstract}

Em conjunto com o furor estatal pela internação, também nesse período as famílias das crianças e adolescentes institucionalizadas foram culpabilizadas pelo "estado de abandono do menor". "A idéia de proteção à infância era antes de tudo proteção contra a família" (RIZZINI \& RIZZINI, 2004, p. 39). “O reconhecimento de que 'a falta de recursos é um dos determinantes das internações' não impediu a disseminação da concepção de que os pais queriam se ver livres dos filhos" (RIZZINI \& RIZZINI, 2004, p. 41). 
Quem olha para essas concepções sob a ótica atual percebe a clara contradição na qual elas incorrem. Pelo menos no campo discursivo, a institucionalização foi questionada antes da incapacidade familiar. A contradição repousa no fato de ambas as ideias possuírem um desenvolvimento independente, afinal, para desinstitucionalizar não é necessário apoiar as famílias ao invés de mantê-las na exclusão social por meio da culpabilização?

O novo Código de Menores de 1979, que instituiu a Doutrina da Situação Irregular, não muito diferente do antigo Código de 1927 e sua Doutrina do Direito do Menor, expunha as famílias populares à ação institucionalizante do Estado pelo simples fato delas serem pobres. O conceito jurídico que viabilizava tal prática era o de "menor em situação irregular", situação basicamente caracterizada pelas condições de vida das camadas mais pauperizadas ${ }^{5}$ (cf. RIZZINI \& RIZZINI, 2004, p. 41). O conceito de "situação irregular" era tão amplo que, na realidade, abarcava toda e qualquer criança ou adolescente em situação de pobreza. Como estar “em situação irregular” era a condição jurídica que permitia e justificava a internação, tal conceito, na prática, construiu a legitimação das internações por pobreza.

\begin{abstract}
A política de segurança nacional empreendida no período da ditadura militar colocava a reclusão como medida repressiva a todo e qualquer sujeito que ameaçasse a ordem e as instituições oficiais. $O$ silêncio e a censura eram poderosos aliados oficiais no sentido de manter a política de internação, nas piores condições que fossem, longe dos olhos e ouvidos da população. (RIZZINI \& RIZZINI, 2004, p. 46)
\end{abstract}

Ao longo dos anos anteriores a 1979, principalmente na década de 1960, já se tinha iniciado um movimento "no sentido de especificar a natureza do tratamento necessário ao menor infrator, distinguindo-o do órfão e do abandonado, ainda que todos fossem caracterizados como em situação irregular" (Silva, 2003, p. 293).

Assim se iniciava um processo de rompimento com o que se tem chamado ao longo deste texto de indiferenciação da demanda, uma das marcas essenciais da área de proteção à infância e à adolescência. A questão da criança e do adolescente vítima de violência começou a se descolar da problemática dos infratores. No entanto, o conceito de situação irregular ainda fornecia uma incômoda unidade às

[...] crianças privadas das condições essenciais de sobrevivência, mesmo que eventuais; às vítimas de maus-tratos e castigos imoderados; às que se encontrassem em perigo moral, entendidas como as que viviam em

\footnotetext{
${ }^{5}$ Conforme pode ser visto no artigo $2^{\circ}$ da Lei $n^{\circ} 6697 / 79$.
} 
ambientes contrários aos bons costumes e as vítimas de exploração por parte de terceiros; às privadas de representação legal pela ausência dos pais, mesmo que eventual; às que apresentassem desvios de conduta e as autoras de atos infracionais. (SILVA, 2003, p. 293)

Foi essa unidade, que se traduzia concretamente em indiferenciação e que começou a ser forjada antes mesmo do Código de 1979, que deu legitimidade conceitual e jurídica para o atendimento conjunto, ou seja, em uma mesma instituição, de todos os perfis descritos acima, viabilizando os grandes complexos da FUNABEM e das FEBEMs. As demandas e as necessidades específicas de cada situação começaram a se diferenciar timidamente na lei, mas, na prática, o atendimento oferecido a essa população continuava indiferenciado e massificado.

Apesar do início da diferenciação apontada acima, em meados do século XX,

[...] o menor passou a figurar em lugar de destaque na Doutrina da Segurança Nacional, sendo efetivamente tratado como um problema de ordem estratégica, saindo da esfera de competência do Poder Judiciário e passando diretamente à esfera de competência do Poder Executivo. (SILVA, 2003, p. 295)

Assim, é importante perceber que a descentralização do poder da esfera judiciária nas questões que envolvem a criança e o adolescente teve o início de sua história justamente a partir da criminalização do "menor".

Esse movimento criminalizador das questões em torno do "menor" fornece uma das bases simbólicas à cultura da institucionalização indiscriminada presente no ideário nacional. Seguindo o modelo prisional, quando uma criança ou adolescente trazia em sua história de vida forte discriminação social, o Estado respondia isolando essa criança ou adolescente, agora transfigurado em "menor", desse mesmo social que o segregou. Novamente pode-se perceber que "esse sistema levou à criação de uma visão cultural contraditória da sociedade brasileira, presente ainda hoje, de proteção-punição" (OLIVEIRA, S. D., 2003, p. 367). Na doutrina da situação irregular não fica claro se o intuito era proteger ou punir. Na realidade, a política de atendimento mobilizada por ambos os Códigos de Menores padecia dessa ambiguidade: proteger punindo, punir protegendo.

A história do controle social formal da infância como estratégia específica constitui um exemplo paradigmático de construção de uma categoria de indivíduos débeis para quem a proteção, muito mais do que constituir um 
direito, consiste numa imposição. (GARCIA MENDEZ \& COSTA, 1994, p. 14)

De maneira genérica, a legislação anterior ao ECA, por meio de seu sistema dual, que ora subordinava as crianças e adolescentes ao Código Civil ora ao Código de Menores, promovia efetivamente um tratamento diferenciado em razão da forma como foram concebidos, de sua origem social ou composição familiar (cf. SILVA, 2003, p. 298), transformando-se em uma máquina de discriminação social.

Tal postura segregacionista acabou por gerar dois "direitos": os direitos da criança e os direitos do menor. E também criou grande confusão em relação às competências de cada um dos poderes.

A posição majoritária [...], que redundou na adoção da Doutrina da Situação Irregular, era no sentido de a Justiça de Menores limitar-se à aplicação do Direito do Menor, relegando os Direitos da Criança à competência do Poder Executivo. (SILVA, 2003, p. 297)

Tal posicionamento entendia que não era função do Poder Judiciário assegurar à criança e ao adolescente direitos tão amplos quanto o direito à saúde, à educação, ao lazer etc.

Nas décadas de 1960 e 1970, Juizados de Menores, como o de São Paulo, atuaram hegemonicamente na área da criança, legislando, normatizando e criando as estruturas de atendimento. No Rio de Janeiro, o Juizado não assumia as funções executivas e em todos os estados brasileiros havia essa indefinição quanto ao que era da competência do Direito da Criança e do Direito do Menor, misturando-se nos Juizados funções executivas e judiciárias. (SILVA, 2003, p. 297)

Como se pode ver, a história da área de proteção à infância e à adolescência nesse período é marcada pela indefinição das funções e competências entre os poderes e, consequentemente, uma grande desarticulação entre os órgãos e instituições.

No entanto, ao longo da década de 1980, toda essa situação começou a mudar. A cultura da institucionalização foi novamente questionada. Assim como qualquer política oficial, a crítica aos internatos só foi possível no bojo do processo mais amplo de redemocratização do país. 
A presença de movimentos sociais fortes e organizados, como, por exemplo, o Movimento Nacional de Meninos e Meninas de Rua, ${ }^{6}$ e o grande interesse de pesquisa que se desenvolveu em torno do tema foram, sem dúvida, fatores que muito influenciaram no questionamento das políticas de proteção baseadas na internação.

Ao invés dos grandes complexos, começava-se a apostar em formas alternativas de atendimento à criança e adolescente, que se realizavam em seus próprios contextos (muitas vezes e rua) e comunidades.

Crescia o entendimento de que o tema era cercado de mitos, como o de que as crianças denominadas de menores - institucionalizados ou nas ruas eram abandonadas; o mito de que se encontravam em "situação irregular" (Código de Menores, 1979), ou de que a grande maioria fosse composta por delinqüentes (RIZZINI \& RIZZINI, 1991). E tomava corpo a compreensão de que o foco deveria recair sobre as causas estruturais ligadas às raízes históricas do processo de desenvolvimento político-econômico do país, tais como a má distribuição de renda e a desigualdade social. (RIZZINI \& RIZZINI, 2004, p. 47) ${ }^{7}$

Pela primeira vez, a crítica pela falência do sistema voltava-se para o seu organizador (o Estado) ao invés de seu destinatário (a criança e o adolescente). A questão da infância e adolescência em situação de vulnerabilidade social deixava "de ser vista como uma questão de filantropia benemérita, de higienização médica, de assistencialismo ou de segurança nacional, para passar a ser vista e enfocada como uma "questão social"” (SILVA, 1997, p. 47).

Vislumbrava-se que quem estava em "situação irregular" não eram os chamados menores, mas sim a política a eles dirigida.

O menino deixa de ser visto como um feixe de carências e passa a ser percebido como sujeito de sua história e da história de seu povo, como um feixe de possibilidades abertas para o futuro. Agora se pergunta o que ele é, o que ele sabe, o que ele traz e do que ele é capaz. (GARCIA MENDEZ \& COSTA, 1994, p. 129)

A "descoberta" de que nem todos que se encontravam institucionalizados eram “abandonados", recolocava a questão da compreensão da família desses meninos e meninas, bem como dos motivos que os levaram a serem internados. Vimos acima que, cada vez mais,

\footnotetext{
${ }^{6}$ Movimento social fundado em 1985 que congregou uma série de experiências alternativas de atendimento à criança e ao adolescente em situação de rua, promovendo a articulação dos diversos projetos, bem como dos próprios meninos e meninas atendidos.

${ }^{7}$ Ao longo deste trabalho perceber-se-á que alguns desses mitos sobre a população abrigada permanecem e outros foram substituídos por novos mitos.
} 
percebia-se que a pobreza era o condicionante principal da institucionalização de crianças e adolescentes no país, situação para a qual deveriam ser construídas novas alternativas de trabalho.

Até então, a lógica subjacente ao sistema de assistência à infância era a de que

[...] internando-se o menor carente, evitava-se o abandonado e, por sua vez, o infrator, [o que] resultou na internação em massa de crianças que passaram por uma carreira de institucionalização, pela pobreza de suas famílias e pela carência de políticas públicas de acesso à população, no âmbito de suas comunidades. (RIZZINI \& RIZZINI, 2004, p. 41)

Além disso, a desmistificação de que todos os que estavam internados eram delinquentes também foi importante no processo de diferenciação das demandas de ambos os grupos e na construção de propostas específicas para cada um.

Obviamente, a FUNABEM não passou incólume por esse processo de mudança. Promoveu uma grande revisão interna de suas ações, durante a qual se destacou

[...] um aspecto que comprometia a ação do Estado: a centralização da política versus a descentralização da execução. Os efeitos se fizeram sentir em todo o país: os estados não tinham autonomia para definir suas ações e alocações de recursos. (RIZZINI \& RIZZINI, 2004, p. 47)

Nesse sistema centralizado, criava-se uma cisão intransponível entre planejamento e execução. Essas duas áreas da política pública não se conversavam. Quem planejava não sabia se as ações propostas faziam sentido dentro de cada realidade local. Por outro lado, quem executava, simplesmente cumpria ordens vindas de uma instância que não o representava, ou seja, que não estava ciente de suas necessidades específicas. Obviamente que, a partir de um planejamento em escala nacional, poda-se a possibilidade de se pensar em soluções que fujam da resposta padrão vinda dos altos escalões.

Ao final da década de 1980, na tentativa de atender às demandas por mudanças, a FUNABEM transformou-se em Centro Brasileiro para a Infância e Adolescência (CBIA), com a missão de apoiar a nova legislação que já se anunciava no país.

Foi uma década de calorosos debates e articulações em todo o país, cujos frutos se materializariam em importantes avanços, tais como a discussão do tema na Constituinte e a inclusão do artigo 227, sobre os direitos da criança, na Constituição Federal de 1988. Mas o maior destaque da época foi, sem dúvida, o amplo processo de discussão e redação da lei que viria substituir o 
Código de Menores (1927, 1979): o Estatuto da Criança e do Adolescente (1990). (RIZZINI \& RIZZINI, 2004, p. 46)

Foi no bojo do Movimento Nacional Constituinte e de seu grande objetivo, no que tange ao reordenamento jurídico, de "remoção do entulho autoritário", que existiram condições favoráveis ao questionamento da Doutrina da Situação Irregular e à adoção da Doutrina da Proteção Integral, já sinalizada em diversos pactos internacionais de direitos humanos desde a Declaração dos Direitos da Criança, adotada pela ONU em 1959.

O artigo 227 da Constituição Federal incorporou todas as garantias legais das cartas internacionais e, ao exigir uma lei específica que o regulamentasse, abriu caminho para o ECA, aprovado em 13 de julho de 1990, e que garantiu direitos amplos e universais, com prioridade absoluta, a todas as crianças e adolescentes em um único código, acabando com o sistema dual e segregacionista vigente até então.

O ECA inaugura outra fase do pensamento assistencial brasileiro sobre crianças e adolescentes, denominada por Silva (1997) de desinstitucionalização (1990-?). Suas principais realizações foram a criação de uma série de dispositivos legais de proteção ao cidadão dos arbítrios do Estado, além de abrigar sob sua tutela não mais apenas a criança em situação de risco social, mas toda pessoa "em fase de desenvolvimento". Ainda, vale ressaltar que o ECA tentou reequilibrar as responsabilidades em relação às crianças e aos adolescentes, tanto com a sociedade civil (com a criação dos Conselhos Tutelares) como com o Poder Judiciário (com a criação das Varas da Infância e Juventude) (cf. SILVA, 1997, p. 35-36). 


\title{
4 O DIREITO À CONVIVÊNCIA FAMILIAR E COMUNITÁRIA: OS AVANÇOS DO ECA EM RELAÇÃO À MEDIDA DE ABRIGAMENTO
}

O ECA nasceu como uma legislação que se contrapõe a séculos de história. Iniciamos o "Breve histórico do abrigamento no Brasil" com uma afirmação que também poderia ser sua conclusão: a de que, ao longo da história, a resposta padrão do Estado para as questões que envolviam a infância pobre e famílias com dificuldades para criarem seus filhos era a institucionalização. Vimos que os internatos foram utilizados equivocadamente como estratégias de enfrentamento da pobreza.

Contrapondo-se a isso, o ECA estabelece o que se considera ser um de seus maiores avanços contra a institucionalização de crianças e adolescentes: a proibição do abrigamento por pobreza.

Tal marco encontra-se fixado em seu artigo 23:

\begin{abstract}
A falta ou a carência de recursos materiais não constitui motivo suficiente para a perda ou suspensão do pátrio poder. Parágrafo Único: Não existindo outro motivo que por si só autorize a decretação da medida, a criança ou adolescente será mantido em sua família de origem, a qual deverá ser obrigatoriamente incluída em programas oficiais de auxílio. (BRASIL, 1990)
\end{abstract}

O Estatuto retoma a questão da "institucionalização como última medida", mas com algumas diferenças essenciais. Em primeiro lugar, devemos colocar a seguinte pergunta: a institucionalização é a última medida para quê? Anteriormente ao ECA, a institucionalização poderiam ser levantada como a última medida em situações de pobreza, por exemplo. Essa era uma espécie de hipocrisia jurídica, que viabilizou a internação de muitas crianças e adolescentes cujo único "pecado" que cometeram foi terem nascido pobres. O Estatuto desfaz essa hipocrisia colocando que, mesmo sendo a institucionalização o último recurso para alguns casos, dentre eles não está a pobreza.

Isso não significa que a criança ou o adolescente que se encontre em situação de pobreza não necessite de proteção. Significa, contudo, que, nesses casos, a institucionalização não pode ser levantada como uma possibilidade de medida, nem que seja a última delas.

Para os casos de pobreza, conforme consta no artigo citado acima, é o núcleo familiar como um todo que deve ser apoiado por meio de sua inclusão em programas sociais. Ainda, 
fica claro que, se a família deve ser apoiada, pois é em seu interior que toda criança e adolescente deve crescer, é porque essas famílias não mais são vistas como incapazes. O que elas necessitam simplesmente é de melhores condições de vida. Além disso, uma vez que o ECA definiu a convivência familiar e comunitária como um direito fundamental de toda criança e adolescente, os abrigos passaram a ter como obrigação trabalhar pela reintegração familiar.

Nesse sentido, quando o ECA retoma o paradigma da institucionalização como última medida é preciso nos perguntar para quais situações ela continua a ser recomendada. $\mathrm{O}$ artigo 98 responde a essa questão:

As medidas de proteção à criança e ao adolescente são aplicáveis sempre que os direitos reconhecidos nesta lei forem ameaçados ou violados: I - por ação ou omissão da sociedade ou do Estado; II - por falta, omissão ou abuso dos pais ou responsável; III - em razão de sua conduta. (BRASIL, 1990)

De modo inédito, o Estado e a própria sociedade constam entre os possíveis violadores de direitos de crianças e adolescentes. Estes, juntamente com a família, formam a tríade incumbida pelo ECA em seu artigo $4^{\circ}$ de assegurar tais direitos. O Estatuto, também de maneira inovadora, surge com a proposta de corresponsabilidade entre essas três instâncias.

Mas a presença do Estado, que historicamente se ausentava de suas responsabilidades no que se refere à assistência à infância e à adolescência, é, sem dúvida, a mudança mais relevante.

No entanto, deve-se lembrar que, mesmo $n$ esses casos que demandam medidas de proteção, o abrigamento é levantado como a última medida a ser considerada. Outro avanço trazido pelo ECA é que ele estabelece uma lista bastante objetiva de ações que devem ser tomadas antes da institucionalização. Essa listagem encontra-se no artigo 101:

Verificada qualquer das hipóteses previstas no art. 98, a autoridade competente poderá determinar, dentre outras, as seguintes medidas: I encaminhamento aos pais ou responsáveis, mediante termo de responsabilidade; II - orientação, apoio e acompanhamento temporários; III - matrícula e freqüência obrigatórias em estabelecimento oficial de ensino fundamental; IV - inclusão em programa comunitário ou oficial de auxílio à família, à criança e ao adolescente; $\mathrm{V}$ - requisição de tratamento médico, psicológico ou psiquiátrico, em regime hospitalar ou ambulatorial; VI inclusão em programa oficial ou comunitário de auxílio, orientação e tratamento a alcoólatras e toxicômanos; VII - abrigo em entidade; VIII colocação em família substituta. Parágrafo Único: O abrigo é medida 
provisória e excepcional, utilizável como forma de transição para a colocação em família substituta, não implicando em privação de liberdade. (BRASIL, 1990)

Percebe-se que toda a rede de apoio é convocada para atuar antes do abrigo: educação (cf. inc. III), saúde (cf. inc. V e VI) e assistência social (cf. inc. IV), sem prejuízo do apoio da própria sociedade civil, por meio de Organizações Não Governamentais (ONGs) ou associações de bairro ou comunitárias (cf. inc. IV).

A atuação em rede é a resposta do ECA para a questão que levantamos em "Breve histórico do abrigamento no Brasil" a respeito da resposta padrão do Estado frente aos casos que necessitam de proteção. $O$ artigo 101 se levanta contra a padronização da institucionalização como forma de atendimento universal proposta pelo Estado. Ali está colocado que o abrigamento é a sétima das medidas de proteção a serem levadas em consideração. E, mesmo assim, o parágrafo único desse artigo estabelece dois importantes princípios que devem reger as práticas dos abrigos: a provisoriedade e a excepcionalidade. $\mathrm{O}$ segundo lança a prerrogativa do que se vinha abordando até o momento. $\mathrm{O}$ abrigamento somente será excepcional quando for a última das medidas possíveis a serem pensadas para um determinado caso. Deve ser utilizado quando todas as demais já fracassaram.

Já a provisoriedade implica em, mesmo quando a institucionalização for necessária, ela deverá ser o mais breve possível. O ECA aboliu o instituto existente nos antigos Códigos de Menores que permitia a "internação até os dezoito anos de idade". Tal medida soa muito mais como uma condenação do que como uma proteção. Além disso, com base em quais critérios o juiz tinha a certeza de que o caso demandaria internação até a maioridade? Atualmente, a provisoriedade implica também que a convivência familiar é algo de que nunca se deve desistir, mesmo para os casos mais difíceis, pois, afinal, cada caso é um caso, e as situações sempre podem mudar.

Os princípios da provisoriedade e da excepcionalidade trazem a marca da "remoção do entulho autoritário" do período ditatorial, movimento iniciado na Constituição Federal, na qual foram condenadas as práticas de custódia do Estado sobre o cidadão. Daí ambos serem mecanismos que salvaguardam as crianças e os adolescentes da institucionalização, histórica prática de custódia do Estado, que pode ser caracterizada como parte desse "entulho autoritário".

No entanto, vale ressaltar que os princípios de provisoriedade e de excepcionalidade ainda estão carentes de regulamentação específica. Isso significa que a legislação precisa 
definir prazos e parâmetros mais objetivos que normatizem os programas de atendimento em abrigos, bem como facilitem sua fiscalização.

Ainda, é importante um esclarecimento a respeito do trecho do parágrafo único deste artigo, o qual versa que o abrigo não implica em privação de liberdade. De fato, ninguém se encontra preso dentro das instituições de abrigamento. No entanto, as saídas das crianças e dos adolescentes devem ser organizadas do mesmo modo como elas ocorrem em toda família: por meio de acordos com os responsáveis. Aonde vai? A que horas volta? Com quem vai?

A postura do abrigo deve ser a mesma da educação de um filho na família. Não é porque todos têm o direito de ir e vir que o abrigo vai permitir saídas de crianças desacompanhadas no período noturno, por exemplo. Não ser uma medida de privação de liberdade não implica que o abrigo deve permitir saídas livres. Isso seria, inclusive, algo contra a própria proteção da criança. Tudo deve ocorrer por meio de acordos e pactos, que costumeiramente os pais realizam com seus filhos.

Com a aprovação do ECA, houve uma mudança inclusive no público-alvo dos abrigos. Os antigos orfanatos atendiam crianças e adolescentes órfãos ou em situação de abandono familiar. Além disso, sabemos que recebiam maciçamente meninos e meninas que tinham parentes, e que lá permaneciam porque suas famílias não tinham condições de criá-las.

Com a proibição do abrigamento por pobreza, o abrigo passa a receber crianças e adolescentes em "situação de risco pessoal ou social". Além do caso dos órfãos e abandonados, estão incluídos, aqui, os casos das vítimas de violência doméstica. A mudança de orfanatos para abrigos engendrou uma redefinição da demanda sob a égide do conceito de violência. $\mathrm{O}$ pano de fundo dessa transformação foi o próprio amadurecimento do conceito de direitos das crianças e dos adolescentes. Afinal, ao se acompanhar o desenvolvimento histórico das políticas de atendimento à infância institucionalizada, vimos que a proteção colocada em pauta era a da sociedade em relação à criança, ou seja, com a institucionalização, visa-se proteger a sociedade de elementos que ela considerava incômodos ou potencialmente perigosos. Nesse contexto, a noção de violência contra a criança ou adolescente simplesmente não possui condições de existência. Ao contrário, elas precisavam ser encarceradas, pois elas é que eram consideradas como violadoras da ordem pública.

O ECA inverteu essa equação: é a criança e o adolescente que devem, quando for necessário, ser protegidos da sociedade, e não o inverso. Sob essa nova base é que se processa a transformação do público-alvo dos abrigos. Essas constatações são importantes para desmistificarmos a ideia de que os atuais abrigos desenvolvem o mesmo atendimento que os 
antigos orfanatos, só que em unidades menores. Os abrigos nascem com uma proposta que questiona a essência do trabalho realizado até então pelos orfanatos. A evolução dos internatos para os abrigos possui a marca da descontinuidade. Trata-se de uma história de ruptura e não de continuidade.

Ao longo de nosso percurso histórico, vimos que os internatos eram um modelo de atendimento que destruía os vínculos, muitas vezes já fragilizados, existentes entre pais e filhos, propunham a concentração de grande número de crianças e adolescentes em um mesmo espaço com atendimento massificado, herdaram dos primeiros internatos católicos o tabu em relação à sexualidade, o que levou à separação entre meninos e meninas, praticavam o isolamento em relação ao mundo externo e ainda foram muito influenciados pelas políticas de segurança pública, o que imprimiu uma característica prisional a muitos desses estabelecimentos.

A resposta do Estatuto a esse percurso histórico vem principalmente sintetizada em seu artigo 92:

\footnotetext{
As entidades que desenvolvam programas de abrigo deverão adotar os seguintes princípios: I - preservação dos vínculos familiares; II - integração em família substituta, quando esgotados os recursos de manutenção na família de origem; III - atendimento personalizado e em pequenos grupos; IV - desenvolvimento de atividades em regime de co-educação; V - nãodesmembramento de grupos de irmãos; VI - evitar, sempre que possível, a transferência para outras entidades de crianças e adolescentes abrigados; VII - participação na vida da comunidade local; VIII - preparação gradativa para o desligamento; IX - participação de pessoas da comunidade no processo educativo. (BRASIL, 1990)
}

A família é colocada em lugar de destaque, como o primeiro e mais importante dos princípios, pois é o que vai garantir a saída da criança e do adolescente do abrigo, ou seja, sem um trabalho de preservação dos vínculos familiares, o desabrigamento se torna impossível.

O inciso II se coloca contra o "modelo da carrocinha", o qual se identifica nas antigas legislações, nas quais, passados 30 dias do recolhimento da criança sem que os pais se manifestassem, esta poderia ser entregue a qualquer pessoa idônea que a desejasse levar.

Contra o atendimento massificado se ergue o inciso III, enquanto o IV garante que meninos e meninas não mais precisarão viver separados. Além disso, a coeducação é uma proposta audaciosa de convivência da diversidade, coibindo a criação de guetos e lugares para determinados perfis identificados como "malditos" (loucos, deficientes, portadores de doenças 
crônicas, negros, filhos ilegítimos etc.). Não mais se farão espaços destinados a cada tipo de criança, pois não haverá mais "tipo de crianças". Ao longo da história, ficou nítido que o conceito de proteção foi sendo ampliado para abarcar dentro de si todas as crianças e adolescentes, sem restrições. Todas são "merecedoras" de proteção. ${ }^{8}$

A valorização da família aparece novamente no inciso V. No VI identifica-se a tentativa de propiciar aos abrigados um ambiente minimamente estável em que possam construir vínculos saudáveis. A presença da comunidade nos incisos VII e IX, bem como a preparação gradativa para o desligamento, são instrumentos para o que o abrigo deixe de cultivar essa cultura isolacionista herdada dos orfanatos.

Neste momento, não haverá aprofundamento no estudo e nas implicações dos princípios que regem o atendimento em abrigos, pois eles serão a base para as análises desenvolvidas em "Análise da atual política pública de abrigamento no Brasil”.

É válido, entretanto, destacar, neste momento, um princípio sobre o qual não se tratará no decorrer do texto, o que justifica sua inserção mais aprofundada nesse momento.

Quando se fala em se evitar, sempre que possível, as transferências de um abrigo para outro (inc. VI), além da mínima estabilidade necessária para a sensação de acolhimento e o desenvolvimento saudável, é importante situar esse princípio dentro de um movimento histórico mais amplo de diferenciação dos abrigos do modelo prisional. Ainda persiste, em muitas instituições de acolhimento, um procedimento de transferência contínua dos casos considerados mais difíceis, tal como se faz com presos que não apresentam bom comportamento dentro das penitenciárias ou ainda que exercem uma liderança negativa sobre os demais.

É esperado que crianças e adolescentes encaminhados aos abrigos tenham alguns traços em comum, como, por exemplo:

[...] histórias marcadas pela descontinuidade de vínculos e trajetórias, por muitas mudanças e constantes rompimentos de seus elos afetivos, além de uma grande demanda por atenção e cuidados que poucas vezes é correspondida. Com frequiência, a urgência de serem ouvidas e terem suas necessidades atendidas são os mais fortes elementos que surgem em suas falas. (RIZZINI \& RIZZINI, 2004, p. 52)

\footnotetext{
${ }^{8}$ Atualmente, as maiores dificuldades encontram-se no campo da operacionalização da proteção. Determinadas ambivalências e dificuldades advindas desse processo de ampliação da proteção serão tratadas quando, em "Análise da atual política pública de abrigamento no Brasil", forem analisadas as atuais propostas de divisão da demanda de abrigamento.
} 
Essa "urgência" é muitas vezes compreendida como indisciplina e mau comportamento. Frente a crianças e adolescentes com comportamento “difícil”, a prática das transferências é algo que necessita ser podado.

Sendo assim, além de estar imbuído de um pensamento de preservação dos vínculos comunitários que a criança ou o adolescente pode construir com a comunidade do entorno do abrigo, o princípio de se evitar as transferências compõe um capítulo importante dentro do processo de reordenamento institucional proposto pelo Estatuto, que engloba a recusa à continuidade de práticas como a descrita anteriormente.

Em relação às famílias das crianças e dos adolescentes institucionalizados, vimos que as concepções variam do anonimato à culpabilização. No primeiro caso, relacionado ao sistema das rodas dos expostos, a família era tão sem importância que não se fazia questão sequer de identificá-la. Ao contrário, conforme o Estado assumiu uma posição central na condução da política de assistência à infância, a instituição familiar adquiriu relevância, mas pelo valor negativo. Sobre ela pairavam as culpas a respeito da situação de seus filhos, discurso que serviu ao Estado para esconder suas próprias responsabilidades sobre a questão. Verificou-se que o Estatuto trouxe uma nova visão em relação às famílias, já que instituiu a convivência familiar como um dos direitos fundamentais de todas as crianças e adolescentes e impõe que, em caso de dificuldades, essas famílias devem ser apoiadas, ao invés de terem seus filhos retirados. ${ }^{9}$

Mas, o que fazer quando se está diante de uma situação de violência doméstica, na qual a convivência da criança ou do adolescente com seu agressor pode lhe trazer prejuízos e o trabalho psicossocial de apoio a essa família com certeza se estenderá por um longo tempo? Sendo coerente com a lógica da "institucionalização como último recurso", o Estatuto, de maneira inovadora, determina em seu artigo 130 que "verificada a hipótese de maus-tratos, opressão ou abuso sexual impostos pelos pais ou responsável, a autoridade judiciária poderá determinar, como medida cautelar, o afastamento do agressor da moradia comum" (BRASIL, 1990).

Novamente, o Estatuto propõe uma inversão na lógica que se impunha até então: a saída do agressor e não da vítima. A ideia não é culpabilizar quem agride, pois sabe-se que também ele, com o devido apoio, pode superar essa situação. A intenção é a de responsabilização. Se, de fato, uma criança está sendo vítima de violência, por que deve ser

\footnotetext{
${ }^{9}$ Desenvolveremos em detalhes o tema das famílias de crianças e adolescentes abrigados em um item especialmente dedicado ao assunto em "Análise da atual política pública de abrigamento no Brasil".
} 
ela a sair de sua casa? Por que é a vítima que deve ser revitimizada para ter seus direitos garantidos? O artigo 130 é mais uma das medidas que devem ser levadas em consideração antes de se efetuar um abrigamento.

Contudo, a grande quantidade de crianças e adolescentes que ainda se vê nos abrigos atualmente é prova de que esse é um artigo pouco cumprido na prática. Como ver-se-á ao longo deste trabalho, esse é mais um exemplo de um avanço legislativo que nunca saiu do papel.

Poderíamos acrescentar, ainda, a dificuldade de que, muitas vezes, o agressor é também o provedor da residência, de modo que afastá-lo do lar implicaria também em retirar daquela família sua fonte de renda. Contudo, esse não seria um problema, caso o Estado conseguisse cumprir com suas obrigações de apoiar aqueles que se encontram em situações como essa, para que essas famílias não tenham a violência como o preço a ser pago pela sua sobrevivência material.

Abordou-se em "Breve histórico dos abrigos no Brasil" que o sistema de proteção desenvolvido antes do ECA apresentava a característica de possuir seu centro de poder extremamente concentrado no Judiciário, especialmente na figura do juiz. Pudemos perceber que esse acúmulo de poder gerou um acúmulo de funções, tendo o Judiciário desenvolvido também atividades que seriam específicas dos outros poderes como o Executivo e o Legislativo.

Para fazer frente a essa situação, o Estatuto cria novos órgãos, redefine as atribuições de cada ator, desenvolvendo um novo sistema de atendimento:

[...] o ECA normatizou a atuação do Poder Judiciário na defesa desses direitos, atribuiu ao Ministério Público e aos Conselhos Tutelares a fiscalização dos mesmos direitos, e aos Conselhos Nacional, Estadual e Municipal a formulação das políticas nacional, estadual e municipal para a criança e o adolescente. (SILVA, 2003, p. 298).

Vemos que o Estatuto organizou a desordem em que se encontrava a área da infância e adolescência, redistribuindo funções e competências entre as esferas de poder, estabelecendo uma nova concepção e gestão das políticas de atenção a esse segmento, originando o que se convencionou chamar de "sistema de garantia de direitos".

Do ponto de vista da concepção, esse sistema destaca-se pelo caráter abrangente, pois incorpora tanto os direitos universais de todas as crianças e 
adolescentes brasileiros quanto a proteção especial a que fazem jus aqueles que foram ameaçados ou violados em seus direitos. Da perspectiva organizacional, o sistema ancora-se na integração interdependente de um conjunto de atores, instrumentos e espaços institucionais (formais e informais) que contam com seus papéis e atribuições definidos no estatuto. Quanto à gestão, o sistema de garantia funda-se nos princípios da descentralização político-administrativa e da participação social na execução das ações governamentais e não-governamentais de atenção à população infanto-juvenil brasileira. (AQUINO, 2003, p. 328)

O sistema construído pelo ECA é dirigido para garantir os direitos universais de todas as crianças e adolescentes, tanto aquelas que necessitam de uma proteção especial quanto as que não. Com isso, ele acaba com o sistema dual imposto pelo Código de Menores, que criava uma dupla jurisdição no interior do modelo de atendimento. A partir de 1990, temos uma lei para todas as crianças e adolescentes, que não mais são subdivididas em tipos sobre os quais incidiria uma legislação diferenciada.

O ECA ainda inovou pelo caráter sistêmico de seu modelo, o qual é impossível de ser compreendido pensando nos atores funcionando isoladamente. "Garantir" direitos de crianças e adolescentes passa a ser compreendido como algo que pode ser dividido em três frentes: a promoção, a defesa e o controle social.

O eixo da promoção é responsável por oferecer as condições concretas para que os direitos instituídos sejam garantidos e materializa-se por meio da formulação e execução das políticas públicas. Os órgãos nele envolvidos são aqueles responsáveis pelo atendimento em saúde, educação, assistência social, esporte, lazer, cultura etc., sejam governamentais ou nãogovernamentais, bem como os conselhos setoriais de deliberação sobre as políticas públicas e os Conselhos de Direitos da Criança e do Adolescente.

No âmbito da defesa estão as instituições que se prestam a garantir os direitos instituídos por meio da responsabilização daqueles que não os respeitam. Nesse caso, a rede congrega principalmente o Judiciário, o Ministério Público e os Conselhos Tutelares. Especificamente ao que se refere ao Judiciário, "apesar do ECA ter rompido com a lógica da concentração de poderes jurisdicionais e administrativos do modelo "menorista", este órgão preservou atribuições de extrema relevância no novo modelo" (AQUINO, 2003, p. 342). No que concerne aos abrigos, o Juizado da Infância e Juventude é o único órgão que pode efetivamente aplicar a medida judicial de abrigo. Outros órgãos, como o Conselho Tutelar principalmente, podem simplesmente encaminhar ao abrigo, devendo este comunicar o juiz no prazo de $48 \mathrm{~h}$ para referendar ou não a atitude realizada. 
Apesar disso, é possível afirmar que o ECA efetivamente fortaleceu o movimento de descentralização do poder da figura do juiz, tornando obrigatória sua assessoria por uma equipe multiprofissional, cuja consulta o Código de 1979 deixava ao arbítrio do magistrado.

\begin{abstract}
A equipe técnica (normalmente composta por um psicólogo e um assistente social, no mínimo) tem o mesmo status científico, pois tanto o juiz quanto o psicólogo e o assistente social são bacharéis. Contudo, o ECA ainda fez uma concessão ao Poder Judiciário, atribuindo maior autoridade ao juiz, quando ali devia estar configurada uma espécie de conselho de sentença, que impediria definitivamente que as decisões relativas à criança fossem tomadas por um único profissional. (SILVA, 2003, p. 298)
\end{abstract}

Segundo o autor, o ECA avançou na questão da descentralização do poder concentrado nas mãos do juiz, mas ainda não o suficiente. Nossa sociedade construiu um mito de que o saber jurídico é equivalente à verdade ou, pelo menos, o que mais se aproxima dela. Temos que compreender o conhecimento legal não como o saber, mas como mais um saber. Não podemos nos esquecer que as normas são construções humanas, tal como os conhecimentos acumulados pela psicologia ou assistência social. Os códigos não se tornam verdades incontestáveis só porque foram instituídos em lei. As leis servem para organizar a sociedade e devem ser rigorosamente cumpridas enquanto estiverem em vigor. No entanto, isso não significa que sejam inquestionáveis. $\mathrm{O}$ fato de que as leis devam ser cumpridas não implica que uma lei deva ser cumprida para sempre.

No entanto, talvez o melhor exemplo da descentralização do poder decisório do Judiciário sobre os destinos das crianças e adolescentes seja a criação dos Conselhos Tutelares, pelo ECA em 1990. É um órgão vinculado administrativamente ao Poder Executivo Municipal, mas de caráter autônomo e permanente (cf. art. 131 do ECA), cujos membros são eleitos pela população para o exercício de um mandato (cf. art. 132 do ECA). Segundo o artigo 136 do Estatuto, o Conselho Tutelar tem, entre outras, as seguintes atribuições: atender crianças e adolescentes com direitos ameaçados ou violados, bem como seus familiares, realizando os encaminhamentos cabíveis tanto à rede de proteção social quanto ao sistema de justiça. Ou seja, é responsável por atividades que, se executadas corretamente, têm a capacidade de evitar que alguns problemas cheguem até o Judiciário. Na realidade, segundo Garcia Mendez e Costa (1994), esta nova instituição "libera os juízes de um acúmulo de tarefas específicas de políticas sociais, e lhes permite concentrarem-se em suas específicas 
jurisdicionais" (p. 59). Nesse sentido, os Conselhos Tutelares têm um importante papel no processo de desjudicialização da atenção dedicada à infância e juventude.

No entanto, na prática cotidiana ainda essas questões permanecem carentes de uma definição mais precisa. Afinal, qual é o limite da atuação dos Conselhos Tutelares em relação ao papel das Varas da Infância e Juventude? O estudo da AASPTJ-SP/NCAPUCSP/SAS/Fundação Orsa (2003) levanta uma dúvida a respeito dessa relação no âmbito de nosso tema:

\begin{abstract}
De quem é a responsabilidade pelo acompanhamento da situação daquele que foi abrigado quando o encaminhamento ocorreu pelo Conselho Tutelar? O acompanhamento da situação de abrigamento é uma questão polêmica em São Paulo: se por um lado justifica-se a centralidade dessa ação por parte da instituição judiciária, dada a existência de um processo judicial e frente à necessidade da intervenção do profissional assistente social ou psicólogo, por outro, deixa-se de atender a finalidade essencial que gerou a criação dos Conselhos Tutelares - a desjurisdicionalização do atendimento de questões que revelam natureza social e não necessariamente legal. (p. 217).
\end{abstract}

Obviamente que uma postura sistêmica e de coparticipação de ambos os órgãos poderiam diminuir muito os impasses acima descritos. No entanto, isso apenas não basta, pois quando a cooperação falha é preciso ter muito bem definidas as atribuições, competências e responsabilidades de cada instância, sob pena, por exemplo, do Conselho Tutelar perder sua especificidade, transformando-se em mero "quintal do Judiciário", ou seja, uma simples extensão dos braços do juiz ou promotor, um mero órgão encaminhador de problemas ao sistema de justiça.

Além disso, o Conselho Tutelar ainda carrega uma série de ambiguidades, talvez devido à sua recente criação. Aquino (2003) aponta que "sua atuação na área da infância e adolescência está marcada por um sentido voluntarista e de busca de gratificação pessoal" (cf. AQUINO, 2003, p. 348), sentido próximo ao que encontramos entre os trabalhadores voluntários dos abrigos.

Para nós, o Conselho Tutelar é a maior inovação e ao mesmo tempo o ponto mais frágil de todo o sistema de garantia de direitos. Apesar do imenso avanço que significou a criação desse órgão em termos de política pública de defesa da criança e do adolescente (por exemplo, na descentralização de poder em torno do Judiciário), o equilíbrio entre as atribuições e responsabilidades dessa instituição ainda não está bem equacionado em relação à capacidade técnica de seus membros. Talvez o exemplo mais eloquente dessa situação seja a 
dificuldade em balancear a representatividade comunitária do conselheiro (a saudável necessidade do conselheiro ser alguém da comunidade e eleito por ela) e sua formação técnica, geralmente aquém das necessidades que sua função exige. Enfrentando situações extremamente complexas sem a devida retaguarda em termos de formação, o trabalho dos conselheiros tutelares tem sido alvo de frequentes decepções em relação ao que se esperava desse órgão quando de sua criação.

Devido ao modo eleitoral de constituição de seus membros, os Conselhos Tutelares "são alvos fáceis de manipulação política e partidarismos locais" (cf. AQUINO, 2003, p. 349). Em relação às discussões sobre o Conselho Tutelar, sob ponto de vista particular do autor deste trabalho, essa problemática da eleição é um dos aspectos principais. Por um lado, a eleição tende a garantir uma importante característica que todo conselheiro tutelar deve possuir: ser uma referência comunitária. Por outro lado, o mesmo procedimento eleitoral não tem garantido a necessária formação técnica desses profissionais que atuam com uma realidade tão complexa. O fato mesmo de serem eleitos, o que é, como já colocado, totalmente legítimo, acaba gerando a saída dos conselheiros justamente quando adquirem mais experiência.

Diante desse quadro, a maneira de ingresso dos conselheiros, bem como sua formação e capacitação para o trabalho é uma questão urgente para o sistema de garantia de direitos e que abre um importante caminho para futuras pesquisas na área. Aquino (2003) indica que “devido a esse tipo de questão, alguns CMDCA's (órgãos responsáveis pela eleição e capacitação dos conselheiros tutelares) vêm introduzindo critérios mais exigentes no processo de seleção dos candidatos, passando a cobrar níveis mais elevados de escolarização (em alguns casos, curso superior completo) e atuação comprovada na área da infância e adolescência, além de organizar cursos de capacitação mais longos e detalhados, buscando, inclusive, o apoio técnico das prefeituras" (AQUINO, 2003, p. 350, nota rodapé).

Outras soluções podem ser levantadas para melhorar essa situação: além da essencial necessidade de capacitação e de formação continuada dos conselheiros, a criação de equipes técnicas de apoio aos Conselhos Tutelares é uma das ações pensadas atualmente. A contradição dessa proposta é que uma ação que visa melhorar a qualidade das intervenções dos conselheiros pode, por outro lado, retirar-lhe autoridade e, consequentemente, sua representatividade.

No entanto, sugere-se que os Conselhos Tutelares possam se aproximar do funcionamento das equipes do Programa Saúde da Família, em que o agente comunitário de 
saúde (que possui representatividade) é sempre acompanhado por uma equipe multiprofissional.

A consequência para os abrigos do atual quadro do Conselho Tutelar, órgão com atribuição legítima de encaminhamento ao abrigo, é que

[...] o problema da ausência ou descontinuidade na capacitação em serviço dos conselheiros eleitos, associado às dificuldades enfrentadas para garantir o acesso de crianças e adolescentes sujeitos à proteção especial e às políticas sociais básicas, ajuda a explicar o fato de que, em muitos casos, os conselheiros se apressam em abrigar crianças e adolescentes em situação pessoal ou social de risco, antes mesmo de propor as demais medidas cabíveis. (AQUINO, 2003, p. 352)

Tal situação, a do abrigamento precoce sem encaminhamentos anteriores aos serviços de proteção básica e sem a aplicação das demais medidas protetivas - que incluem, segundo o artigo 101 do ECA, encaminhamentos às redes das políticas sociais, orientação e acompanhamento temporários e inclusão em programas de auxílio e apoio sociofamiliar - tem se constituído em um maiores problemas para os abrigos, uma vez que todas as medidas citadas podem ter a capacidade de evitar o abrigamento.

No entanto, o ônus de tal situação não deve ser cobrado somente dos Conselhos Tutelares, pois, se estes encaminham crianças e adolescentes aos abrigos, elas só permanecem nos serviços de acolhimento com o aval do Judiciário. Nesse sentido, podemos inferir que essa "mentalidade institucionalizante" não está presente somente entre os conselheiros tutelares, mas também entre os membros do Judiciário brasileiro, o que, muitas vezes, faz da postura individual do conselheiro tutelar ou do juiz o fator decisivo da opção pelo abrigamento em detrimento das demais medidas de proteção possíveis.

Finalmente, o eixo do controle social tem como objetivo garantir os direitos instituídos por meio da fiscalização e da aferição contínua dos serviços prestados às crianças e aos adolescentes. Esse é o eixo em que está prevista a maior participação da sociedade civil organizada, que pode se expressar por meio dos Fóruns de Direitos, bem como dos próprios Conselhos de Direitos e de políticas setoriais. O Ministério Público e os Conselhos Tutelares também podem exercer a fiscalização das instituições de atendimento.

É importante perceber que um mesmo órgão pode atuar em mais de uma frente. É justamente essa característica que oferece dinamismo e interconectividade ao sistema. Se cada um dos eixos de garantia de direitos (promoção, defesa e controle) fosse exercido por uma 
única instituição isoladamente, esse não seria um sistema, mas sim uma simples justaposição de instituições. Um dos casos interessantes que se pode citar é o dos conselhos de políticas setoriais que participam tanto da formulação das políticas públicas como de sua fiscalização, o que tende a evitar a segmentação do trabalho.

No entanto, essa mesma sobreposição de funções e tarefas tem, na prática, se transformado em desarticulação e trabalho isolado. É fato reconhecido em muitos municípios que, apesar dos avanços na legislação, a atuação das redes locais tem se dado de forma fragmentada (cf. AQUINO, 2003, p. 347).

Ainda, segundo o mesmo autor, alguns dos principais obstáculos à integração da rede são:

[...] a não-absorção das competências de cada organização estabelecidas no sistema de garantias e dificuldade de compatibilizar os "paradigmas" diferenciados das instituições envolvidas na proteção integral". (cf. AQUINO, 2003, p. 347)

No que se refere ao primeiro aspecto mencionado,

[...] o fato de que as competências estabelecidas não são desempenhadas pelos atores das redes locais, em muitos casos, deve-se à indefinição prática sobre quem vai desempenhar funções que estão legalmente sobrepostas entre os diferentes órgãos. (AQUINO, 2003, p. 347)

O autor exemplifica a questão citando a fiscalização das entidades de abrigo, função concorrente do Judiciário, Ministério Público e Conselho Tutelar. Se a rede não se articular e planejar conjuntamente suas atividades de fiscalização, é provável que nenhum desses três órgãos fiscalize os abrigos, contando que o outro o faça, ou ainda que fiscalizem de modo a não cobrir toda a rede de abrigos existente ou não divulgar coletivamente os resultados obtidos.

Na grande maioria dos casos, [a fiscalização] é feita de forma esporádica, como uma atividade ocasional, em virtude da quantidade de outras atribuições dos órgãos competentes e da escassez de recursos com que trabalham. É também comum que as fiscalizações aconteçam em caráter de urgência, como resposta a denúncias de violação de direitos nas entidades de abrigo. (AQUINO, 2003, p. 348) 
Em relação ao segundo aspecto, o da incompatibilidade entre as diferentes culturas organizacionais, Aquino exemplifica a questão trazendo o Juizado da Infância e Juventude e o Conselho Tutelar, o primeiro pertencente a uma estrutura de poder com raízes extremamente profundas no quadro institucional brasileiro e gozando de alto capital simbólico, muitas vezes assumindo, em razão disso, uma postura explicitamente corporativista e autoelogiosa; e o segundo, com uma estrutura novíssima e sem precedentes na organização pública brasileira, ainda sem a exata compreensão de seu papel e sem qualquer (ou quase nenhum) prestígio social (cf. AQUINO, 2003, p. 347). Ao contrário, o conselheiro tutelar é visto pela população em geral como aquele que "vem tirar as crianças dos pais".

Vimos também em nosso recuo histórico que, inicialmente, o Estado se eximiu da sua responsabilidade de coordenar o sistema de proteção à infância e à adolescência, deixando essa incumbência à Igreja. Quando essa situação começou a se transformar, o modelo proposto pelo Estado padecia de uma forte centralização, especialmente concentrada na esfera federal. Tal configuração distanciou a coordenação e o planejamento das ações da população que efetivamente necessitava dos serviços, criando um sistema cujas instituições promoviam um atendimento descontextualizado.

Como alternativa a tudo isso, o ECA promoveu uma nova divisão de tarefas no interior do Estado. Sua presença continuou forte no interior do sistema, afinal o Estado é corresponsável (cf. art. $4^{\circ}$ ) pela situação da criança e do adolescente no país. No entanto, a instância administrativa que é identificada como a que deve ser mais fortalecida passou a ser a municipal e não mais a federal que, ao longo do tempo e com o apoio financeiro e logístico dos estados e da federação, deve assumir a execução dos serviços.

No que se refere à política de atendimento, o ECA abriu caminho para as legislações e marcos regulatórios mais atuais (como a Lei Orgânica da Assistência Social - 1993 - e a Política Nacional de Assistência Social - 2004 -, por exemplo), que têm a municipalização como princípio para a execução das políticas públicas dirigidas à criança e ao adolescente, ficando a esfera federal responsável pela coordenação geral, estabelecimento de diretrizes de atuação e cofinanciamento, ou seja,

[...] no que se refere à gestão dos recursos repassados do fundo nacional para o fundo municipal de assistência social, prevê-se que os municípios terão autonomia para geri-los, segundo a realidade e as prioridades locais. (AQUINO, 2003, p. 334) 
O pressuposto baseia-se nos ganhos que

[...] a proximidade entre as instâncias gestoras e a população podem trazer em termos da maior atenção às especificidades de cada município, da otimização dos recursos financeiros envolvidos e da ampliação da eficiência e do impacto das ações. (AQUINO, 2003, p. 334)

No entanto, isso não significa que

[...] é apenas o município que deve assumir e responsabilizar-se pela solução de todos os problemas, eximindo o Estado e a União. A municipalização significa que o governo local, que está mais próximo da população, assume um papel central na formulação e implementação de políticas de atendimento, com o indispensável apoio técnico e financeiro do Estado e da União [...] (AASPTJ-SP/NCA-PUCSP/SAS/Fundação Orsa, 2003, p. 49)

Municipalização é muito diferente de "prefeiturização" que, evidentemente, não tem capacidade de gestão e execução dos serviços sem o apoio das demais instâncias federativas.

No entanto, segundo Aquino (2003), a descentralização ainda não possibilitou as mudanças previstas, pois a

[...] confusão/não-incorporação dos papéis de cada ente no modelo compartilhado de gestão, a "subordinação" dos municípios nas decisões sobre a política e a insuficiência de apoio na sua condução em nível local são problemas na articulação entre as três esferas de governo que incidem diretamente sobre a capacidade dos municípios de absorver novas demandas e reorganizar as redes de serviços, os programas e os projetos da área segundo as prioridades locais. (AQUINO, 2003, p. 339)

Um exemplo dessa situação na área dos serviços de acolhimentos institucional é que, apesar da maior parte do serviço ser prestada por ONGs, os Estados ainda possuem muitas unidades de abrigo, principalmente na região Nordeste. Um dos problemas que se pode levantar advindos dessa situação é a notória

[...] dificuldade das redes estaduais de penetrarem em grande número de municípios, tendendo a concentrar-se nos maiores, o que muitas vezes provoca o deslocamento de crianças e adolescentes de seus municípios de origem para aqueles onde se situam as entidades que irão abrigá-los. (AQUINO, 2003, p. 340) 
Tal situação dificulta o acesso dos familiares dos abrigados, violando o princípio do Estatuto, que prevê o incentivo à preservação dos vínculos familiares, bem como retira a criança ou o adolescente do ambiente que lhe era familiar, abalando seu direito à convivência comunitária.

Somente a rede municipal tem a capilaridade necessária para executar serviços que possuem a territorialização/regionalização como seu princípio de distribuição no espaço. Esse modelo preconiza que um serviço deve estar localizado no próprio espaço geográfico em que habita a população que ele pretende atender.

No entanto,

[...] tal constatação sugere a necessidade de cada região buscar as próprias soluções para o enfrentamento da questão, seja por meio da criação de abrigos, seja por meio de outras alternativas, evitando-se repassar sua demanda para o município de São Paulo, o que, dentre outras questões, desfavorece o processo de reintegração familiar. (AASPTJ-SP/NCAPUCSP/SAS/Fundação Orsa, 2003, p. 144)

Aquino (2003) ainda aponta a falta de engajamento da população local como mais um dos entraves que tem dificultado a efetivação da municipalização das políticas de assistência social, já que, nesse processo, a participação da sociedade civil é essencial para o seu desenvolvimento. "O sucesso da municipalização depende, entre outras coisas, de uma sociedade atuante nos espaços formais e informais de discussão" (AQUINO, 2003, p. 338). Nesse sentido, podemos apontar que concomitantemente aos desenvolvimentos na construção democrática das políticas públicas (mesmo que ainda distantes de estarem consolidados) devemos lutar também por avanços na educação política dos cidadãos brasileiros, condição sem a qual todo processo democrático estará condenado ao fracasso.

Outra característica histórica da rede de atenção à criança e ao adolescente abandonados ou vítima de violência é a indissociação de suas necessidades específicas de atendimento das demandas de outro grupo social caracterizado atualmente pelo nome de infratores. Chama-se essa característica de "indiferenciação da demanda".

A partir dessa conscientização, o ECA trabalha com duas categorias: as medidas de proteção, já listadas quando se apresentou o artigo 101, e as medidas socioeducativas, identificadas no artigo 112: 
Verificada a prática de ato infracional, a autoridade competente poderá aplicar ao adolescente as seguintes medidas: I - advertência; II - obrigação de reparar o dano; III - prestação de serviços à comunidade; IV - liberdade assistida; V - inserção em regime de semiliberdade; VI - internação em estabelecimento educacional; VII - qualquer uma das previstas no art. 101, I a VI. (BRASIL, 1990)

Não se aprofundará, aqui, nas questões que envolvem o ato infracional, pois isso mudaria totalmente os rumas da pesquisa. Além disso, como se pôde perceber pelo histórico que foi traçado, um dos maiores desafios quando se estuda crianças e adolescentes vítimas de violência é separar sua demanda daquela engendrada por aqueles que cometeram ato infracional. No entanto, vale apenas o comentário que é possível percebe que a diretriz da "institucionalização como última medida" permanece para as medidas socioeducativas e também a tentativa de, mesmo na medida de internação, diferenciá-la do modelo prisional, já que o texto do Estatuto especifica que a internação deve ocorrer em "estabelecimento educacional". Entende-se que esses estabelecimentos devam se assemelhar mais a uma escola fechada do que a um presídio. Ainda, vê-se que também não se coloca a ideia de culpabilização do adolescente autor de ato infracional, uma vez que lhe é garantido através do inciso VII o usufruto de todas as medidas de proteção, com exceção do abrigo e da adoção. Ou seja, aquele que está em conflito com a lei também merece ser protegido.

Retornando ao ponto de maior interesse para este estudo, o destaque da nova legislação, no que concerne aos serviços de acolhimento institucional, é a distinção estabelecida entre abrigamento e internação. "A institucionalização de crianças e adolescentes era indistintamente chamada de internação. Todavia, a partir do Estatuto da Criança e do Adolescente (ECA) as medidas de 'internação' e 'abrigo' tornam-se distintas (AASPTJSP/NCA-PUCSP/SAS/Fundação Orsa, 2003, p. 15).

Assim, o abrigamento foi concebido como a última das medidas de proteção, adotáveis quando uma criança ou adolescente encontra-se em situação de direitos violados. O abrigo é a última dessas medidas a ser listada no ECA, pois deve ser a última a ser adotada na prática. Isso se justifica devido ao caráter revitimizador do abrigamento, já que se afasta a criança ou o adolescente das pessoas e do ambiente que lhe eram familiares. No entanto, vê-se que, em muitos casos, o abrigamento não tem se configurado como a última das medidas protetivas a serem adotadas.

Já a internação foi caracterizada como a última das medidas socioeducativas aplicáveis no caso de adolescentes em conflito com a lei. A distinção entre medidas de proteção e 
medidas socioeducativas colabora com a ruptura da clássica indiferenciação da demanda que historicamente caracterizou a área das políticas públicas à infância e à adolescência, propondo serviços de atendimento diferenciados para crianças e adolescentes vítimas de violência e infratores.

Por fim, pode-se dizer de modo mais genérico que o ECA inova ao propor o rompimento desse modelo dos internados já que, a partir de sua promulgação, os abrigos devem necessariamente se voltar para fora dos muros institucionais e criar programas de atendimento que incorporem as famílias das crianças e dos adolescentes e que promovam, o mais rapidamente possível, o retorno destes para o convívio familiar. Os abrigos devem se tornar instituições muito peculiares: instituições que trabalhem pela desinstitucionalização. Devem ter como objetivo de seu trabalho o seu próprio fim enquanto serviço prestado. Será que isso é possível? Essa é uma contradição que deveria nos levar a defender o fim desse modelo de acolhimento? Ou, pelo contrário, tal contradição reúne condições para ser uma espécie de força motriz desse trabalho tão complexo. Espera-se ao longo deste estudo reunir alguns elementos que ajudem a responder tais questionamentos. 


\title{
5 ANÁliSE DA ATUAL POLÍTICA PÚBLICA DE ABRIGAMENTO NO BRASIL
}

\author{
"O Brasil é um país com tradição de responder com \\ institucionalização nos casos de situação \\ de vulnerabilidade de crianças e adolescentes." \\ (Plano Nacional de Convivência Familiar \\ e Comunitária, 2006, p. 59)
}

Este capítulo será dedicado ao estudo pormenorizado da atual política de abrigamento no país, por meio da análise dos números disponíveis sobre o assunto. O objetivo é avaliar se as deficiências e as limitações diagnosticadas em visita à história dos abrigos e supostamente sanadas no plano jurídico com o advento do ECA realmente impactaram as instituições de acolhimento do modo como se esperava. A pergunta que move este trabalho é: se os avanços que identificamos em "O direito à convivência familiar e comunitária: os avanços do ECA em relação à medida de abrigamento" de fato se concretizaram no modo como os serviços de abrigamento atualmente funcionam. Propõe-se um exercício de comparação entre o ideal fixado em lei e a realidade dessas instituições expressa pelos números das maiores pesquisas quantitativas existentes no Brasil sobre essa realidade.

Nesse ponto, é importante lembrar que "quanto à questão do atendimento em instituições, cabe destacar que um processo de diagnóstico e avaliação da situação atual apenas se inicia" (RIZZINI \& RIZZINI, 2004, p. 49). É nesse início de um movimento de conhecimento da realidade do abrigamento no Brasil de hoje que se gostaria de situar este trabalho.

Ao lembrar da pujança de estudos sobre o tema de crianças e adolescentes institucionalizados na década de 1980, atualmente, pelo menos "no que se refere à produção acadêmica, poucos estudos sobre a institucionalização de crianças nestes últimos anos foram detectados. O tema parece ter saído de foco” (RIZZINI \& RIZZINI, 2004, p. 49).

Paradoxalmente, o grande interesse de pesquisa sobre essa realidade silenciou-se com o advento do ECA. A hipótese, neste estudo, para esse fato relaciona-se à ilusão criada com o advento dessa lei tão progressista e avançada de que o problema estaria resolvido e que, portanto, não era mais preciso se preocupar com ele. 
Provavelmente, por isso, "o tema tem sido tratado com certa confusão e perplexidade diante das denúncias de maus-tratos e formas hediondas de violação dos direitos da criança e do adolescente em instituições por todo o país" (RIZZINI \& RIZZINI, 2004, p. 49).

Atualmente, percebe-se um momento de novo nascimento do interesse de pesquisa direcionado às crianças e aos adolescentes que vivem em abrigos, talvez motivado pela descoberta incômoda que os problemas associados à institucionalização ainda persistem no Brasil.

\subsection{As instituições de acolhimento}

Iniciar-se-á o estudo da atual política pública de abrigamento focalizando as próprias instituições responsáveis pela sua execução.

\section{$\underline{\text { 5.1.1 Características gerais }}$}

O Levantamento Nacional pesquisou 589 instituições que ofereciam programas de abrigo, em todas as regiões do Brasil, acolhendo por volta de 20.000 crianças e adolescentes. Destes, quase a metade localiza-se na região Sudeste $(49,1 \%)$ e mais de um terço em São Paulo (34,1\%), enquanto que o Estado com o segundo maior índice de abrigos (o Rio Grande do Sul) sequer chega a 10\% (cf. IPEA, 2003, p. 1). Em outras palavras, é possível afirmar que se está diante de uma realidade bastante desigual em termos regionais.

Em São Paulo, a pesquisa da AASPTJ-SP, NCA-PUCSP, SAS e Fundação Orsa (2003) constatou um total de 190 instituições, abrigando 4.847 crianças e adolescentes.

Dentre os abrigos pesquisados em âmbito nacional, a grande maioria localiza-se em áreas urbanas (90,3\%), sendo apenas 8,3\% na zona rural (MELLO, 2003, p. 143). Um dado como esse poderia indicar que as crianças e os adolescentes da cidade sofrem mais violência do que as do campo. Mas, a hipótese deste estudo não vai nesse sentido. Parece que a violência é um fenômeno que, em suas diferentes formas, atinge a todos, em todas as classes sociais, em todos os lugares. Sendo assim, considera-se que as crianças e os adolescentes 
campesinos estão sujeitos a tanta violência quanto aqueles que vivem nas cidades, embora estejam submetidas a processos diferentes. Certo é que uma parte da imensa discrepância encontrada entre as porcentagens de abrigos urbanos e rurais pode ser explicada pela diferença de concentração demográfica desses locais. No entanto, considera-se que outra parte dessa divergência pode ser compreendida a partir do fato de que a rede de proteção à infância e à adolescência (Conselhos Tutelares, Conselhos de Direitos, Varas da Infância e Juventude etc.) ainda não se estruturou em determinadas localidades afastadas do campo brasileiro. Quando as crianças e os adolescentes têm seus direitos violados, o fato é que simplesmente não se fica sabendo ou, mesmo quando se toma conhecimento, não se possui estrutura para intervir.

Outro apontamento importante é que uma criança ou um adolescente morador do meio rural que necessite de abrigamento, muito provavelmente será acolhido em uma instituição distante de sua região de origem, desrespeitando seu direito de ser protegido sem ser privado de suas referências comunitárias.

No entanto, tal situação também pode ser encontrada nas grandes cidades, como em São Paulo. Isso porque os serviços de acolhimento institucional costumam estar localizados em regiões distantes da moradia de seus atendidos. ${ }^{10}$

O Mapa da Exclusão ${ }^{11}$ retrata a segregação da periferia da cidade, onde se observam poucos equipamentos sociais. Dessa forma, a periferia foi sendo deixada de lado por inúmeros governantes, que não investiram em políticas públicas sociais e, quando muito, o fizeram em programas fragmentados e de pouca sustentação, sujeitos à descontinuidade com as mudanças de lideranças. (AASPTJ-SP/NCA-PUCSP/SAS/FUNDAÇÃO ORSA, 2003, p. 14)

Aliada à falta de interesse e planejamento dos gestores públicos, talvez a rápida expansão característica das grandes metrópoles brasileiras ajude a compor os argumentos explicativos da rarefeita presença dos equipamentos públicos nas periferias. A consequência de tal situação para os abrigos, que também seguem a tendência de concentrarem-se nas regiões centrais, é o forte desenraizamento vivenciado pelas crianças e adolescentes quando são abrigados, uma vez que normalmente estes se originam das regiões periféricas e são

\footnotetext{
${ }^{10}$ Dedicar-se-á um momento do texto para tratar especificamente sobre essa questão.

${ }^{11}$ SPOSATI, A. (coord). Mapa da exclusão/Inclusão social da cidade de São Paulo: dinâmica social dos anos 90. São Paulo: Educ, 2000.
} 
acolhidos nas regiões centrais, dificultando também a manutenção do vínculo com as famílias de origem.

Em São Paulo, por exemplo, as regiões onde existem mais abrigos são a Sul (32\%) e a Leste (29\%), fato que indica a coincidência da maior concentração de abrigos nas regiões com maiores índices de pobreza e demais fatores de risco social (cf. AASPTJ-SP/NCAPUCSP/SAS/FUNDAÇÃO ORSA, 2003, p. 68).

No entanto,

[...] apesar das regiões sul e leste, já indicadas na introdução como aquelas que têm os maiores índices de vulnerabilidade social, concentrarem maior quantidade de abrigos, é especialmente nos extremos dessas regiões que os equipamentos deixam de existir, observando-se maior concentração na direção da região central. (AASPTJ-SP/NCA-PUCSP/SAS/FUNDAÇÃO ORSA, 2003, p. 74)

Reunindo algumas informações podemos dizer que, apesar de grandes diferenças regionais, ${ }^{12}$ o perfil geral dos abrigos no Brasil é o seguinte: urbanos (90,3\%), nãogovernamentais (65\%), com grande influência religiosa $(67,2 \%)$ e com predomínio da religião católica (64,6\%) (cf. IPEA, 2003, p. 2).

Em relação à tradição religiosa dessas instituições, "De fato, o atendimento em serviços de abrigo para crianças e adolescentes sempre teve maior participação de instituições filantrópicas e religiosas do que de serviços governamentais" (SILVA \& MELLO, 2003, p. 28).

Esse quadro reflete a história dos cuidados à infância: ausência do Estado e domínio da Igreja Católica sobre a questão da assistência aos pobres e carentes.

Não é surpreendente esse grande número de abrigos que disseram manter algum vínculo ou orientação religiosa, uma vez que, no Brasil, os cuidados com os órfãos e abandonados foram assumidos desde o final do século XVIII pelas irmandades e Santas Casas de Misericórdia. Apenas no início do século XX essa questão passou a ser uma preocupação de Estado, quando foram criados os reformatórios ou institutos correcionais. Ainda assim, a ação estatal era mais voltada para os "infratores" do que para os "carentes e abandonados”. (SILVA \& MELLO, 2003, p. 77)

\footnotetext{
${ }^{12}$ O Nordeste é, na maioria dos índices analisados no Levantamento Nacional, a região mais atrasada em termos de política de abrigamento.
} 
Essa postura do Estado fez com que, além do atraso para conceber a pobreza e a miséria como assuntos de sua competência, a ação estatal tivesse como foco prioritário de intervenção a questão dos "infratores" em detrimento à problemática dos "carentes e abandonados", não enxergando que, muitas vezes, a carência e o abandono podem ser considerados como uma das causas da infração. O Estado, adotando uma postura mais correcional e repressiva do que preventiva, iniciou seus trabalhos na área da infância e da juventude pobre querendo sanar as consequências, mas sem se debruçar sobre as causas.

Em São Paulo, apesar da porcentagem de instituições que possuem vinculação religiosa permanecer bastante elevada (51\%) (cf. AASPTJ-SP/NCAPUCSP/SAS/FUNDAÇÃO ORSA, 2003, p. 63), a taxa é significativamente menor que a média nacional. Além disso, a religião católica responde por $31 \%$ dessas entidades, que apresentam um quadro mais diversificado de vinculações religiosas. Tal situação talvez possa ser compreendida a partir das próprias características da vida metropolitana: maior ecletismo cultural, menor religiosidade, maior estruturação do Estado e maior profissionalização das equipes de trabalho, influenciadas até pela maior proximidade com os grandes centros de ensino e pesquisa universitária.

Em relação ao que dispõe o ECA, pensamos que a existência de instituições com manifestação religiosa clara e definida deve ser considerada, no mínimo, como carregada de ambiguidades. Em seu artigo 16, é garantida à criança e ao adolescente a liberdade de crença e culto religioso. O tempo em que as crianças eram "obrigadas" a seguir a religião de seus pais ficou para trás, pelo menos no que se refere à sua legitimidade jurídica. Desse modo, no caso de crianças e adolescentes abrigados, é a instituição de acolhimento que deve lhes propiciar tal direito, incluindo em seu projeto pedagógico a oferta de uma pluralidade de experiências no campo religioso, sempre de acordo com o interesse da criança e do adolescente.

Os serviços de acolhimento devem propiciar, ainda, que a criança e o adolescente possam satisfazer suas necessidades de vida religiosa e espiritual. Nesse sentido, deve ser viabilizado o acesso às atividades de sua religião, bem como o direito de não participar de atos religiosos e recusar instrução ou orientação religiosa que não lhe seja significativa. (OTSACA, ${ }^{13}$ 2008, p. 9)

\footnotetext{
${ }^{13}$ Orientações Técnicas para os Serviços de Acolhimento para Crianças e Adolescentes, (2008), documento de orientação aos abrigos produzido pelo Conselho Nacional dos Direitos da Criança e do Adolescente (Conanda) e pelo Conselho Nacional de Assistência Social (CNAS).
} 
Isso significa também que os atendidos de um abrigo devem ter a possibilidade de experimentar diversos credos e cultos religiosos, garantindo que a instituição não exerça qualquer tipo de doutrinação nesse sentido: "Nenhuma criança ou adolescente deverá ser incentivado ou persuadido a mudar de orientação religiosa enquanto estiver sob cuidados em serviço de acolhimento" (OTSACA, 2008, p. 9).

No entanto, sabe-se que o interesse histórico das mais variadas igrejas pelas crianças está intimamente ligado à necessidade de se conseguir novos fiéis. Desse modo, têm-se muitas dúvidas a respeito de até que ponto um abrigo que seja institucionalmente definido como seguidor de uma determinada religião tem a capacidade de propiciar e incentivar essas vivências em outras religiões.

Em relação à prevalência de instituições privadas, em São Paulo, essa questão se acentua a ponto de se constituir como uma das mais importantes características dessa rede municipal, sendo que apenas $2 \%$ deles são públicos e, ainda assim, são instituições ligadas ao governo do Estado (cf. AASPTJ-SP/NCA-PUCSP/SAS/FUNDAÇÃO ORSA, 2003, p. 56).

A relação entre abrigos públicos e privados é permeada por vantagens e desvantagens em ambos os lados. Como exemplos, pode-se apontar que uma prevalência de abrigos privados pode criar algumas dificuldades de encaminhamento, principalmente dos casos tidos como "mais difíceis", ${ }^{14}$ já que essas instituições costumam trabalhar com número fechado de vagas e não é raro que elas escolham os perfis com os quais irão trabalhar, concentrando os perfis não escolhidos nos abrigos públicos. Isso acaba por desenhar nas redes de abrigos em que existe um grande número de instituições privadas um sistema muito pouco acolhedor. Por outro lado, os abrigos privados costumam ter mais facilidade no manejo de verbas, bem como na gestão de recursos humanos. Uma ONG tem muito mais facilidade para contratar pessoas com perfil para o trabalho, bem como para despedir aquelas que não apresentam o rendimento esperado.

A questão da manutenção das instituições é outro aspecto que se pode citar como uma vantagem dos abrigos privados. A burocracia para o gasto de recursos no setor público muitas vezes dificulta o atendimento em instituições altamente instáveis, como os abrigos. Estes são um serviço muito mais dinâmico do que a burocracia estatal consegue acompanhar. Essas instituições, por se constituírem em uma casa, têm uma característica bastante peculiar em relação às demais instituições públicas, principalmente em relação às pequenas necessidades

\footnotetext{
${ }^{14}$ Tal situação será mais bem descrita no item "O atendimento oferecido", quando se tratará especificamente das Casas de Passagem.
} 
do dia a dia: uma lâmpada queimada, um cadeado que precisa ser trocado, uma cortina rasgada etc. Esses e outros pequenos gastos costumam ficar por conta dos próprios funcionários. Considere-se, ainda, em uma escola, por exemplo. Se faltar luz ou se algum encanamento se romper e o serviço de manutenção demorar a executar o conserto, talvez a pior coisa que possa acontecer é dispensar os alunos e mandá-los de volta para suas casas. Mas o que se faz em um abrigo se o encanamento se rompe e a instituição fica sem água para cozinhar, tomar banho ou mesmo usar o banheiro? Mandar os atendidos de volta para suas casas?

Como possíveis desvantagens da rede privada, pode-se levantar que muitos abrigos particulares têm uma grande tendência ao isolacionismo de suas instituições, tanto em relação aos demais atores do sistema de garantia de direitos como em relação à aceitação e ao cumprimento da legislação em vigor. O ECA tem encontrado resistências à sua aceitação por muitas dessas instituições.

\begin{abstract}
A avassaladora mudança de cultura provocada pelo ECA na sociedade brasileira, entretanto, não foi ainda suficiente para demover de suas práticas de institucionalização prolongada os abrigos de filantropos e famílias, as instituições religiosas que mantêm grandes redes de abrigos, e organizações da sociedade civil que importaram e fomentaram no Brasil práticas estrangeiras de abrigamento, como Rotary e Lions Clube. Algumas das instituições desse tipo são auto-suficientes, não recebem recursos públicos e, por essa razão, não se sentem obrigadas ao registro da entidade e de seus programas no Conselho Municipal dos Direitos da Criança e do Adolescente local, não recebem encaminhamentos feitos pelo Conselho Tutelar, nem se submetem à fiscalização das autoridades judiciárias. (SILVA, 2003, p. 299)
\end{abstract}

Sendo assim, os abrigos particulares são uma das frentes em que o Estatuto ainda encontra dificuldades de inserção. Por sua independência financeira, julgam-se isentos das responsabilidades e diretrizes que tal lei estabelece. Esquecem-se de que o Estatuto garante direitos para todos os abrigados e não somente para aqueles que estão em instituições que recebem financiamento público. As instituições de abrigamento privado no Brasil são um verdadeiro mundo paralelo, no qual não se sabe muito bem o que se pode encontrar.

A pesquisa realizada em São Paulo pela AASPTJ-SP/NCA-PUCSP/SAS/Fundação Orsa (2003) mostra um pouco dessa realidade, indicando que "mais de 50\% dos abrigos não têm convênio com o poder público (p. 82). Apesar de alguns abrigos apontarem dificuldades para a obtenção do financiamento, "alguns dos entrevistados declararam não desejá-lo, em razão de preferirem autonomia para atender e gerenciar as questões do abrigo" (p. 82). 
No entanto, o que se deve entender como "autonomia para atender e gerenciar as questões do abrigo"? Será que não se está diante de instituições resistentes à fiscalização e à avaliação pública de seus serviços? Entidades com medo da transparência inerente a qualquer proposta de trabalho em rede?

Pode-se citar um exemplo, retirado da mesma pesquisa, que indica que

[...] embora o percentual de imóveis com a aparência de prédio escolar [inadequado, portanto, ao serviço de abrigo, pois se distancia da proposta de aparência residencial] tenha sido baixo em relação às outras modalidades encontradas, sinaliza-se que, dentre eles, as maiores percentagens recaíram nos abrigos não conveniados. (AASPTJ-SP/NCAPUCSP/SAS/FUNDAÇÃO ORSA, 2003, p. 79)

Cabe aqui combater alguns mitos presentes no imaginário social que vêm garantindo prestígio e legitimidade para muitas dessas instituições. Ainda existe no Brasil a ideia de que quanto maior o tempo de permanência da criança ou do adolescente dentro de um abrigo, mais eficiente é o trabalho dessas instituições, pois conseguem mantê-los por mais tempo longe das ruas. Outro mito é o de que quanto maior o terreno e as acomodações físicas de um abrigo, melhor o serviço que ele oferece. A partir do reordenamento proposto pelo ECA, vultosas cifras financeiras e grande capacidade de atendimento não mais são sinais de qualidade dos serviços, mesmo porque a maioria desses abrigos demasiadamente grandes não consegue cumprir com o princípio da semelhança residencial. E ainda, a idealização presente em torno da adoção internacional que, muitas vezes, adquire mais o caráter de mercantilização do que de filantropia, além de poder desrespeitar o princípio legal de que a colocação em família substituta deve ser feita quando já se esgotaram todos os recursos de manutenção da criança na família original e, mesmo quando isso é inviável, a adoção internacional deve sempre ser um recurso utilizado depois de esgotadas as possibilidades de adoção nacional.

No entanto, não são somente os abrigos privados que desrespeitam os direitos de crianças e adolescentes. Tem-se acompanhando ao longo de todo o trabalho os dados colhidos pelo Levantamento Nacional e fica muito claro que também os abrigos públicos e aqueles que recebem financiamento do Estado são grandes descumpridores da legislação em vigor. É por isso que se encontra em Silva (2003) a recomendação de "revisão, nos três níveis da administração pública, das políticas de convênios, para que o poder público não continue financiando práticas de violação dos direitos da criança e do adolescente" (IPEA, 2003, p. 297). Na cidade de São Paulo, por exemplo, o governo estadual possui 33,3\% de sua rede de 
abrigos conveniados atendendo um número de crianças e adolescentes por unidade de acolhimento que varia de 48 a 150 (AASPTJ-SP/NCA-PUCSP/SAS/FUNDAÇÃO ORSA, 2003, p. 90), o que explicitamente contraria o princípio consagrado pelo ECA de atendimento em pequenos grupos.

Apesar de se poder diagnosticar o começo de um movimento em direção ao conhecimento de sua própria rede de atendimento, o Estado, em suas três esferas administrativas, ainda possui poucas informações a respeito dos serviços que ele mesmo oferece e, consequentemente, de como poderia oferecê-lo melhor.

Ainda no que se refere às ONGs, sua presença expressiva na área indica uma tarefa importante, mas que não será tratada com profundidade nesse trabalho: quem quiser entender os abrigos, terá que compreender os avanços e retrocessos do terceiro setor. No entanto, vale somente ressaltar que o grande número de entidades não-governamentais não exime o poder público de suas responsabilidades. Ao contrário, as reforça ainda mais no sentido do

[...] cumprimento de seu papel de coordenar um sistema, com vistas à efetiva implementação de uma política de proteção especial conforme prevista no ECA, bem como na garantia de apoio técnico e financeiro necessário às ações realizadas pela sociedade civil. (SILVA \& MELLO, 2003, p. 75)

Contudo, diferenças regionais como, por exemplo, o fato da região Norte possuir $68 \%$ de abrigos públicos, indicam que o fenômeno da terceirização do serviço de acolhimento institucional é mais característico de determinadas regiões, principalmente a Sudeste, onde $79,9 \%$ dos abrigos são não-governamentais.

Em relação ao tempo de funcionamento dos abrigos, o Levantamento Nacional nos traz um dado preocupante: 58,6\% dos abrigos foram fundados a partir de 1990 (IPEA, 2003, p. 2), ano da promulgação do ECA. O aumento do número de abrigos após 1990 é, em parte, explicado pelo início do processo de desmonte dos grandes complexos e a consequente reordenação de sua demanda. Assim, o número de crianças e adolescentes que eram atendidos em um internato, passou a ser acolhido em várias instituições de abrigo. "Essa ampliação do número de equipamentos foi fruto, portanto, das diretrizes de reordenamento político (municipalização) e da personalização do atendimento em abrigos, estabelecidas pelo ECA" (AASPTJ-SP/NCA-PUCSP/SAS/FUNDAÇÃO ORSA, 2003, p. 209).

A aprovação do Estatuto representou um verdadeiro marco para a área da defesa dos direitos da infância e da adolescência, pois proveu o país do efetivo amparo legal para essa 
parcela da população. Assim, a partir de 1990, todas as instituições de assistência às crianças e aos adolescentes tiveram que se adequar ao novo marco jurídico, que propunha diversas alterações em seus regimes de atendimento.

No entanto, o que preocupa é que, se a maioria das entidades de abrigo foi criada após essa data, já deveriam funcionar de acordo com a nova legislação. Entretanto, não é o que as pesquisas apontam, como será mostrado ao longo do trabalho. Pode-se dizer que, em sua maioria, não são instituições muito antigas. Já nasceram sob a luz do ECA e, mesmo assim, não o cumprem.

Destaca-se que a herança dos internatos e o seu gradual desmonte estão na origem da inadequação e da heterogeneidade das atuais unidades de abrigamento.

Se, em princípio, o retrato desses abrigos seja incompatível com a proposta do ECA, historicamente contextualizado, constata-se que foi resultando de um processo de reordenamento que representou um avanço no sistema de atendimento que funcionava até então, tendo em vista que as unidades da FEBEM/SP, [por exemplo], chegavam a abrigar até 500 crianças. (AASPTJSP/NCA-PUCSP/SAS/FUNDAÇÃO ORSA, 2003, p. 210)

De fato, muitas foram as conquistas e os avanços ao longo de quase 20 anos de Estatuto. No entanto, ainda existe um longo caminho pela frente, como será apontado nessa parte de nosso estudo. O que precisa ficar claro é que se está no meio de um processo histórico, ou seja, apenas foi iniciado um movimento de luta contra um modelo antigo de atendimento à infância e à adolescência que ainda está longe de ser consolidado.

A partir do exposto, é possível estabelecer um balanço preliminar do impacto do ECA no esforço de adequação dos abrigos à nova forma de atendimento ali proposta. Percebe-se que o Estatuto ainda não teve a força esperada na modificação do quadro histórico de atendimento em abrigos. Como exemplos, pode-se citar as questões da concessão de registros para funcionamento das entidades (previsto no art. 90, parágrafo único) e de sua fiscalização. Se o impacto do ECA tivesse sido mais efetivo, não se teria permitido a abertura de instituições em desacordo com a nova legislação ou, então, pela via da fiscalização, ter-se-ia proibido a continuidade daquelas que não se adequassem. Encontra-se uma eloquente ilustração do que se está tratando em Silva \& Mello (2003, p. 86): "Entre as instituições que acolhem crianças e adolescentes de apenas um dos sexos é surpreendente verificar que 46,1\% foram criadas após a promulgação do ECA, sem atender ao princípio da co-educação". 
A lei no Brasil ainda é, em muitos casos, letra morta. Uma entidade nova pode atuar de modo antigo na maneira como atende sua demanda, ou seja, não é necessário que uma instituição tenha séculos de funcionamento para reproduzir séculos de história.

\section{$\underline{5.1 .2 \mathrm{O} \text { atendimento oferecido }}$}

A seguir destacam-se alguns indicadores essenciais do atendimento que as instituições de acolhimento oferecem.

5.1.2.1 Não-especialização no atendimento, coeducação e faixa etária ampliada: três princípios contra a exclusão

A maioria dos abrigos pesquisados $(85,9 \%)$ não oferece qualquer especialização no atendimento (cf. IPEA, 2003, p. 2), ou seja, acolhe toda e qualquer criança ou adolescente em situação de risco pessoal ou social, o que é de extrema importância para se evitar a segregação de certos grupos, como pessoas com deficiência ou portadoras do vírus HIV, por exemplo. Entretanto, apenas $12,6 \%$ das instituições têm um ambiente físico adaptado a pessoas com deficiências, por exemplo. É uma contradição bastante significativa, que exemplifica uma característica existente em muitos projetos e empreendimentos no campo social com os quais se tem entrado em contato: existe a "boa intenção", mas não a capacidade de realização.

São Paulo mantém aproximadamente a mesma porcentagem de abrigos com atendimento especializado (16,67\%), distribuídos em $41 \%$ para portadores de doença mental, $26 \%$ para portadores de HIV, $13 \%$ para crianças e adolescentes com vivência de rua e $10 \%$ para gestantes (cf. AASPTJ-SP/NCA-PUCSP/SAS/FUNDAÇÃO ORSA, 2003, p. 104).

Mesmo sendo uma minoria, a existência desses abrigos é preocupante, pois estão na contramão da atual proposta de inclusão:

Devem ser evitadas especializações e atendimentos exclusivos, tais como adotar faixas etárias muito estreitas, direcionar o atendimento apenas a 
determinado sexo, atender exclusivamente (ou não atender) crianças e adolescentes com deficiência ou portadores de HIV, entre outros. A atenção especializada, quando necessária, deverá ser proporcionada por meio da articulação com a rede de serviços, a qual poderá contribuir, inclusive, na capacitação específica dos cuidadores. (OTSACA, 2008, p. 29, grifo no original)

Por outro lado, constata-se que apenas 42,5\% dos abrigos paulistanos que não contam com atendimento exclusivo aceitam portadores de deficiência mental. Desses com atendimento supostamente inclusivo, apenas $43 \%$ acolhem portadores de HIV e 56,5\% recebem crianças e adolescentes com vivência de rua (cf. AASPTJ-SP/NCAPUCSP/SAS/FUNDAÇÃO ORSA, 2003, p.107, 109, 111). Em outras palavras, quase metade da rede de atendimento é excludente em relação aos três grupos acima analisados. Nesse sentido, o que se considera mais preocupante do que a existência de abrigos especializados é a recusa de determinados perfis por aqueles que deveriam acolher todos os tipos de demanda. Talvez se possa dizer que os abrigos especializados ainda existem, mesmo depois de seu desaconselhamento pelo ECA como uma resposta à falta de receptividade naqueles que deveriam ser inclusivos.

A recomendação da não-especialização no atendimento dá provas de um novo modelo que defende a inclusão como princípio de atendimento. Tanto o Estatuto como as demais leis reguladoras da área visam contribuir com a ruptura da histórica tendência segregadora no atendimento àqueles que diferem da norma. Aos diferentes (loucos, drogados, infratores, crianças abandonadas, deficientes etc.) era tradicionalmente reservado um espaço de clausura, sendo o regime prisional o modelo central a ser seguido pelas demais modalidades de atendimento.

A nova proposta para os abrigos é que estes sejam espaços de convivência da diversidade. Algo ousado e de difícil realização. Mas uma criança portadora de necessidades especiais ou com algum distúrbio psiquiátrico, por exemplo, tem o direito de permanecer em um abrigo, caso seja vítima de violência intrafamiliar. No entanto,

[...] a atenção especializada, quando necessária, deveria ser proporcionada por meio da articulação com outros serviços públicos e, talvez, a partir de pequenas adaptações no espaço e na organização do abrigo, como aconteceria em uma residência comum. (SILVA \& MELLO, 2003, p. 86) 
Deve ser um espaço de convivência dos diferentes, no formato de moradia, cujas necessidades específicas não devem ser atendidas somente dentro da instituição. Ao contrário, é essencial que tais necessidades sejam supridas pelas demais instituições da rede (saúde, educação, cultura etc.). A inclusão não significa que o abrigo terá que dar conta, sozinho, de todas as demandas daqueles que acolhe. Nesses casos, a divisão de responsabilidades da assistência social principalmente com as áreas da saúde e educação é essencial para o atendimento integral dessas crianças e adolescentes.

Existem, contudo, princípios consagrados pela legislação que encontraram um bom índice de concretização. Deve-se citar aqui a recomendação do atendimento em regime misto de coeducação (art. 92, inc. IV), efetivado em 78,1\% dos abrigos pesquisados. Na cidade de São Paulo, esse índice chega a $87 \%$ (cf. AASPTJ-SP/NCA-PUCSP/SAS/FUNDAÇÃO ORSA, 2003, p. 93).

O princípio do regime da coeducação é talvez o mais questionado pelo senso comum. Instituições que atendem a apenas um dos sexos é algo muito característico dos abrigos do passado e indicam uma extrema dificuldade desses serviços em lidar com a questão da sexualidade. ${ }^{15}$ Separar meninos e meninas é uma maneira ilusória de se convencer de que a sexualidade não emergirá. É varrer a "sujeira" para debaixo do tapete, fechando os olhos para o fato de que a sexualidade pode se expressar por muitas vias, como, por exemplo, a da homossexualidade ou ainda dirigida aos educadores/cuidadores das instituições, ainda mais nessa fase de constante transformação e experimentação, característica da sexualidade das crianças e dos adolescentes. Além disso, o objetivo de um abrigo é promover um ambiente o mais próximo possível do usual, ou seja, um ambiente em que meninos e meninas convivem. Se não for assim, quando saírem do abrigo, esses jovens poderão encontrar muitas dificuldades para se relacionar com o sexo oposto.

Devido ao passado religioso do atendimento à infância e à adolescência, o tema da sexualidade sempre foi, e ainda é, um tabu. Na realidade, o que o princípio da coeducação (art. 92, inc. IV) faz é "forçar" os serviços de acolhimento a encarar essa problemática, impedindo juridicamente soluções pretensamente facilitadoras sobre a questão. A doutrina defendida no Estatuto parte do pressuposto de que a convivência entre os sexos é sempre mais saudável, apesar dos "riscos", do que a segregação entre os mesmos. A ideia é que um serviço

\footnotetext{
${ }^{15}$ Seguindo o objetivo dessa pesquisa, não deter-se-á para tratar do tema da sexualidade no abrigo em profundidade, assunto que, por si só, mereceria um estudo à parte. Assim, limitar-se-á a apontar a diretriz do atendimento a essa questão, tal como pode ser depreendida da proposta subjacente ao ECA.
} 
de acolhimento, principalmente aqueles que atendem crianças ou adolescentes sem vínculos familiares e que, portanto, passarão muito tempo no abrigo, deve ser capaz de construir a autonomia de seus acolhidos em todos os seus sentidos, inclusive a autonomia sexual.

Outro princípio que também está sendo razoavelmente cumprido, como é o caso de $53 \%$ das instituições pesquisadas, é o das instituições que trabalham com faixa etária ampliada $^{16}$ (cf. IPEA, 2003, p. 2). Juntamente com o regime de coeducação, essa é uma característica importante para a diversificação da convivência dentro do abrigo, aproximandoo do que se encontra em situações não-institucionais, bem como para possibilitar que se cumpra o princípio de não-desmembramento de grupos de irmãos (art. 92, inc. V do ECA).

$\mathrm{Na}$ realidade, as recomendações mais atuais pregam que o atendimento de todo abrigo deveria ser de 0 a 17 anos e 11 meses, ou seja, todas as idades passíveis de abrigamento. De fato, qualquer segmentação do atendimento por faixa etária, por mais ampla que seja, tende a ser potencializadora da separação de irmãos. Nesse sentido, a constatação de que na cidade de São Paulo, por exemplo, mais da metade $(55,6 \%)$ dos abrigados são formados por grupos de irmãos, "indicando a existência de famílias dentro do próprio abrigo" (AASPTJ-SP/NCAPUCSP/SAS/FUNDAÇÃO ORSA, 2003, p. 147), só vem reforçar a importância da recomendação acima mencionada.

A faixa etária ampliada coloca algumas perguntas a respeito da possibilidade de se segmentar os abrigos em faixas de idade, tal como nas escolas ou creches, ainda mais quando se considera a importância, especialmente para as crianças, da convivência com pares coetâneos. Assim, poderiam existir abrigos especializados no atendimento às crianças e outros dirigidos ao acolhimento específico de adolescentes. Essa é, na realidade, uma das segmentações mais comuns da demanda de abrigamento.

No entanto, este estudo considera que tal proposta de divisão da demanda não leva em consideração a especificidade da instituição "abrigo" em relação às escolas e creches. É central lembrar que o abrigo não é uma instituição de ensino e que as categorias utilizadas para compreensão desses estabelecimentos muitas vezes não se adequarão harmoniosamente à análise das instituições de acolhimento. Se nas escolas e creches faz muito sentido a divisão por faixa etária como estratégia para aproximar os níveis de conhecimento dos alunos, no abrigo, como a questão dos conteúdos formais (curriculares) não se coloca, pois sua proposta

\footnotetext{
${ }^{16}$ Diferença superior a 10 anos entre a menor e a maior idade atendida por uma instituição.
} 
centra-se justamente na educação informal, ${ }^{17}$ talvez seja mais interessante apostar nas possibilidades de aprendizagem advindas da convivência entre as diferentes idades.

Os princípios da coeducação, da recomendação de não-especialização dos serviços e da faixa etária ampliada levantam uma questão que precisa ser melhor debatida: a necessidade de se trabalhar com a diversidade.

Tal discussão pode levar a algumas armadilhas. Uma delas é acabar se negligenciando que certas crianças e adolescentes necessitam realmente de atendimento extremamente específico e especializado, e que são poucas as instituições que têm uma equipe capacitada para atuar de modo coerente frente a toda essa diversidade. Outra armadilha é que crianças e adolescentes têm necessidades diferentes e específicas que não podem ser esquecidas. Muitas vezes, quando se fala simplesmente em "abrigo" acaba-se por encobrir todas essas peculiaridades.

É preciso ter claro que o abrigo é um lugar onde demandas extremamente diferentes se encontrarão. É plausível habitarem debaixo de um mesmo teto meninos que até o dia anterior moravam nas ruas, meninas que muitas vezes ainda saem à noite para se prostituírem, portadores de deficiências físicas e/ou mentais, usuários de drogas, vítimas de abuso sexual, de violência física, aqueles que passarão pouco tempo abrigados, aqueles que não possuem família e, portanto, passarão muito tempo abrigados, os que estão muito atrasados na escola ou ainda aqueles que possuem algum problema crônico de saúde. Cada uma dessas complexas situações demanda dos profissionais envolvidos em cada caso um estofo teórico-prático igualmente complexo. A vastidão de questões envolvidas exige dos trabalhadores dos abrigos uma formação que, na maioria das vezes, esses não a possuem. Nesses casos em que as diferenças não conseguem ser elaboradas, a tendência é que cada funcionário atue a partir dos conteúdos advindos de sua experiência pessoal, quase sempre repleta de preconceitos.

Tais argumentos deveriam levar ao questionamento da proposta atual baseada nos três princípios enumerados anteriormente? Este estudo pensa que não. Ao invés de segregar a demanda sob a justificativa de que as equipes que atualmente trabalham nos abrigos não têm a formação e nem a capacitação necessária para trabalhar com a complexidade que advém dessa proposta inclusiva, tem-se que assumir o desafio de formar e capacitar os trabalhadores dessas instituições, sob a pena de punir as crianças e os adolescentes com um atendimento compartimentalizado, atendendo a uma necessidade que é dos adultos e não deles. As crianças

\footnotetext{
${ }^{17}$ Retornar-se-á à questão da educação informal quando for tratado, no item sobre os trabalhadores do abrigo, sobre o educador social.
} 
e adolescentes não devem pagar por uma incompetência daqueles que deveriam estar preparados para o trabalho altamente complexo de cuidar de uma população tão vulnerável.

Um dos preconceitos mais comuns relacionados a essa questão da não-especialização, advindos da falta de formação dos funcionários dos abrigos é o poderíamos denominar de "teoria da laranja podre" para caracterizar o típico raciocínio que prega a segregação dos diferentes sob a justificativa de preservação daqueles que se consideram normais ou saudáveis. "Não podemos acolher um usuário de drogas, pois ele irá levar nossas crianças para as drogas". Tal ponto de vista desconsidera que o "diferente" também tem direitos e que sua situação, por mais complicada que seja, sempre pode ser compreendida a partir de um determinado contexto e, mais importante, sempre pode ser revertida. Se esse "contágio" negativo pode, de fato, ocorrer, costuma-se esquecer que o oposto também é verdadeiro (as influências positivas) e é o deve ser buscado.

Como exemplo dessa mentalidade segregacionista amplificada para toda a política pública, pode-se citar que

[...] dos abrigos pesquisados, $13 \%$ informaram que não admitem usuários de drogas, $4 \%$ não aceitam crianças ou jovens que tenham vivência de rua e $6 \%$ exigem que a criança ou o adolescente tenha boas condições de saúde. (AASPTJ-SP/NCA-PUCSP/SAS/FUNDAÇÃO ORSA, 2003, p. 102)

Restrições desse tipo são verdadeiros absurdos. Fica claro que existe um perfil que sobra: adolescente usuário de droga com vivência de rua. A pesquisa da AASPTJ-SP/NCAPUCSP/SAS/Fundação Orsa (2003) revelou que 38\% das crianças e adolescentes abrigados na cidade de São Paulo possuem algum tipo de problema de saúde (p. 173). É um índice alto, mas totalmente esperado, uma vez que essas pessoas não estavam submetidas a condições dignas de vida. Ora, se existem abrigos que, por exemplo, exigem boas condições de saúde como critério de entrada, tais instituições já excluem quase $40 \%$ da demanda que necessita de proteção, ou seja, nem a rede de proteção consegue ser inclusiva.

Na realidade, como uma espécie de síntese de todos os "perfis-problema" apontados acima, costuma sempre aparecer a figura do adolescente. É o adolescente que traz todos os vícios para dentro dos abrigos e se constitui como um mal a ser combatido. Essa situação pode claramente ser expressa nos números da política pública. Em São Paulo, por exemplo, "constatou-se que crianças acima de oito anos têm mais dificuldades para serem admitidas nos abrigos" (AASPTJ-SP/NCA-PUCSP/SAS/FUNDAÇÃO ORSA, 2003, p. 95). Compreende- 
se, agora, que a divisão da demanda seguindo uma lógica etária está muito mais imbuída de desejos de exclusão de uma determinada faixa de idade considerada problemática do que de boas intenções em relação à possibilidade de propiciar um atendimento que se conforme melhor às necessidades específicas de crianças e adolescentes.

A sociedade aceita que se cuide das crianças, mas parece segregar os adolescentes a um limbo de descuido. Nesse ponto, esses abrigos parecem reproduzir o mesmo preconceito daqueles que são pretendentes à adoção: querem se restringir às crianças pequenas para, por exemplo, terem a sensação de controle sobre sua educação, sensação esta que é sempre ilusória. De modo geral, fica claro que nosso conceito socialmente construído de proteção não engloba os adolescentes.

Ainda, outro problema em relação à existência de abrigos com restrição de atendimento é a concentração dos casos mais complexos e que demandam intervenções mais cuidadosas nas instituições com atendimento universal. Tal situação acaba sobrecarregando aqueles que optaram por cumprir integralmente a proposta da legislação vigente, como uma punição que se paga por cumprir a lei. Assim, é urgente que se repense a existência de abrigos com esses tipos de restrições e sugerem-se dois mecanismos para se levar a cabo esse reordenamento: proibição da renovação de seus registros nos CMDCAs de seus respectivos municípios e cancelamento do processo de conveniamento (para as cidades que trabalham com essa modalidade de atendimento) com essas instituições, de modo que se pare de penalizar aqueles que cumprem a lei, enquanto o Estado continua conivente com práticas de exclusão.

Poder-se-ia, ainda, contra-argumentar que a não-especialização parte de um pressuposto de que todos são iguais, ou seja, de uma uniformidade ilusória. Sob a camada de princípio inclusivo, repousaria, na verdade, uma tentativa disfarçada de negação da diferença. No entanto, considera-se que o desafio que está colocado é o de reconhecer cada um em sua diversidade, tanto de escolhas como de necessidades. E que a igualdade que está posta em lei é a igualdade de direitos.

No entanto, tais assertivas não significam que se deve negar as dificuldades que a nova proposta inaugurada pelo ECA implica.

Entretanto, apesar deste estudo defender a inclusão, não se pode ser ingênuo. Tanto a literatura especializada como os documentos oficiais reconhecem que as dificuldades desse processo são imensas e que, por isso, alguns critérios precisam ser estabelecidos. Maricondi (1997), por exemplo, recomenda que, no caso de deficientes mentais, o índice de portadores 
não ultrapasse $10 \%$ dos atendidos de um abrigo. A Norma Operacional Básica de Recursos Humanos do Sistema Único de Assistência Social - NOB-RH/SUAS (2006) também determina que abrigos que possuem atendidos que demandem atenção específica, tais como pessoas com deficiência, pessoas soropositivas, com idade inferior a um ano etc., devem possuir um quadro funcional maior (p. 15).

Em outras palavras, não se trata simplesmente de adotar uma postura triunfalista em torno das diretrizes avançadas da legislação e deixar de refletir sobre as possibilidades e os limites para sua implantação. O que o ECA estabelece é um ideal a ser atingido e não uma realidade que se encontra cotidianamente na maioria dos abrigos.

É preciso desconfiar desses altos índices encontrados pelo Levantamento Nacional a respeito da coeducação, não-especialização e faixa etária ampliada. Isso porque esses índices conseguem quantificar apenas o aspecto mais objetivo desses princípios: se os abrigos atendem meninos e meninas juntos e se fazem algum tipo de restrição aos perfis de atendimento. Não medem a qualidade das relações estabelecidas.

No início de minha atividade profissional, fui trabalhar em uma instituição que possuía uma heterogeneidade tão extremada que o abrigo se transformava em um imenso barril de pólvora, uma bomba-relógio sempre prestes a explodir. Essa experiência traumática teve o saldo positivo de extinguir em mim as ingenuidades de quem nunca havia trabalhado com uma demanda tão complexa, sempre acreditando que, em qualquer situação, toda diversidade é bem-vinda. Pude perceber que os conflitos, muitos deles extremamente violentos, aconteciam não tanto por conta das diferenças individuais entre aqueles que moravam no abrigo, mas principalmente pelas diferenças entre os grupos identitários que ali se estabeleciam. Eram os grupos que brigavam entre si e não as pessoas. Como conclusão, aprendi que não se deve desistir do ideal da convivência da diversidade, mas se esta não for bem trabalhada, transforma-se em diferença, segregação e, consequentemente, em violência. Nesse sentido, o abrigo vive, hoje, um dilema muito parecido com a escola: possui em seu interior uma heterogeneidade que passa a ser altamente explosiva, ou seja, geradora de conflitos, pois ambas as instituições ainda não conseguiram desenvolver condições de elaborar essa diversidade em termos produtivos.

Diante desse quadro, poder-se-ia perguntar como é possível não especializar se existem demandas tão diferentes? Por outro lado, a pergunta que decorre da primeira é: como então é possível especializar sem criar guetos e lugares de malditos? 
5.1.2.2 Modalidades e tipos de abrigos: dividir para segregar ou dividir para melhor incluir?

Tentar-se-á responder a essa questão com um documento elaborado conjuntamente pelo Conselho Nacional dos Direitos da Criança e do Adolescente (Conanda) e pelo Conselho Nacional de Assistência Social (CNAS) chamado Orientações Técnicas para os Serviços de Acolhimento para Crianças e Adolescentes - OTSACA (2008).

Em relação aos serviços de acolhimento institucional, as OTSACA (2008) fazem basicamente duas grandes subdivisões, mas que ainda não são especializações. São modalidades de abrigos: os abrigos institucionais e as casas-lares (cf. p. 29).

A diferença das casas-lares para os abrigos institucionais é que nestas "pelo menos uma pessoa ou casal trabalha como cuidador(a) / educador(a) residente - em uma casa que não é a sua" com o objetivo de "estimular o desenvolvimento de relações mais próximas do ambiente familiar" (OTSACA, 2008, p. 39).

A presença de um educador residente tem a vantagem de propiciar aos atendidos uma proposta de cuidado mais uniforme e estável, ocupando um lugar de referência afetiva constante, já que se extingue o modelo dos abrigos institucionais baseado em escalas de trabalho, ou seja, a pessoa que cuida da criança ou adolescente é sempre a mesma.

Outra característica desse sistema é que, como o número de educadores é menor (apenas um educador ou ainda um casal), o número de atendidos também deve ser necessariamente menor, o que possibilita um atendimento mais personalizado, uma rotina mais flexível e, portanto, menos institucional.

A desvantagem é que este é um sistema que esgota o educador que, apesar de estar previsto algum sistema de folgas, fica praticamente impossibilitado de desenvolver uma vida própria independentemente de seu trabalho. Comendo no trabalho, dormindo no trabalho, enfim, morando no trabalho, para essas pessoas o trabalho transforma-se em sua vida inteira.

O texto das OTSACA destaca que a casa-lar deve propiciar ao educador residente

[...] condições para a privacidade do trabalhador e construção de projetos pessoais. Para tanto, deve-se prever períodos livres diários e um esquema de folgas semanais que possibilite sua participação em atividades outras que não as da casa, além de férias anuais fora do ambiente da Casa Lar. (OTSACA, 2008, p. 40) 
No entanto, este pesquisador é um pouco cético quanto à possibilidade disso se concretizar na prática, sem qualquer prejuízo tanto ao trabalhador como aos atendidos. As próprias OTSACA parecem estar cientes dessas limitações quando ressaltam que

[...] especial atenção deve ser dada à clarificação do papel a ser exercido por este profissional, de modo que não se pretenda substituir o lugar e a função dos pais ou da família de origem. É de suma importância que o educador/cuidador tenha clareza quanto ao seu papel: deve vincular-se afetivamente e contribuir para a construção de um ambiente próximo ao ambiente familiar, evitando, porém, "apossar-se" da criança ou do adolescente, bem como competir ou desvalorizar a família de origem ou substituta, quando for o caso. (OTSACA, 2008, p. 40)

Caso isso não ocorra, pode acontecer da própria instituição de acolhimento, que deveria trabalhar no sentido da reintegração familiar, acabe incentivando na criança ou adolescente uma ideia de permanência indefinida no abrigo. É nesse sentido ainda que "se recomenda a substituição do termo largamente utilizado "mãe/pai social" por cuidador/educador residente, de modo a evitar a ambigüidade de papéis" (OTSACA, 2008, p. 40). Ainda que se convencione de nomear a pessoa que cuida das crianças e adolescentes abrigados de "educador residente", o perigo que se corre com essa proposta é o seu incentivo de que essa pessoa acabe se colocando no lugar da família de origem, obstruindo o processo de retorno familiar. É por isso que se recomenda esse modelo como adequado para crianças e adolescentes sem perspectivas de desabrigamento e que, portanto, terão uma longa permanência em medida de abrigamento. Para os casos de curta permanência, o "abrigo comum" talvez seja mais recomendado.

Ainda, prevê-se a existência de uma equipe técnica que, além do acompanhamento constante do educador residente, continua tendo como responsabilidade o atendimento às crianças e aos adolescentes abrigados e suas famílias, visando a reintegração familiar. ${ }^{18}$

Uma vez descrita essa modalidade de atendimento, interessa debater para quem ela seria interessante. As OTSACA fazem três recomendações.

A primeira delas é que a casa-lar seria um modelo mais adequado para "grupos de irmãos" (OTSACA, 2008, p. 41). Como não há explicações além desse direcionamento pontual, ficamos sem saber por que esse modelo seria mais interessante para um grupo de irmãos abrigados em conjunto do que para uma criança ou adolescente que foi abrigada

\footnotetext{
${ }^{18}$ Essas funções serão tratadas mais detidamente no item dedicado aos trabalhadores dos abrigos.
} 
sozinha. Afinal, ambos se beneficiariam de um modelo mais próximo ao ambiente familiar, com cuidados mais estáveis e individualizados.

A segunda recomendação parece fazer mais sentido. Diz o documento que a casa-lar seria uma modalidade mais interessante para

[...] crianças e adolescentes que necessitem de acolhimento por período mais prolongado, nas situações em que não podem voltar a morar com seus pais ou família extensa, porém existem fortes vínculos entre os mesmos, como nos casos de pais/mães/responsáveis em cumprimento de pena privativa de liberdade, em longos períodos de hospitalização ou com transtorno mental severo, que inviabilize a prestação de cuidados regulares, dentre outras situações. (OTSACA, 2008, p. 41, negrito no original)

Para este estudo, fica muito clara a intenção da proposta: crianças e adolescentes com perspectiva de longa institucionalização teriam muito a ganhar com um ambiente mais próximo do familiar, com maior estabilidade e cuidados individualizados, afinal, eles terão que permanecer muito tempo no abrigo. E a questão da existência de "fortes vínculos" com a família de origem entra no sentido de se contrapor à tendência de naturalização da institucionalização presente nessa modalidade de atendimento.

Imagine como seria viver por anos em um local onde, em todo momento, entram e saem pessoas novas. Pense que a cada novo atendido que entra ou sai, toda a dinâmica interna da instituição se modifica, inclusive os jogos de força e liderança entre as próprias crianças e adolescentes abrigados. O dispêndio de energia para se manter atento a essas constantes transformações e a necessidade de permanecer sempre alerta às novas configurações simbólicas, lideranças e forças locais faz do "abrigo comum” um lugar bastante inóspito para se viver de modo mais prolongado.

Além disso, imaginemos também a sensação de quem fica no abrigo ao ver seus colegas, um após o outro, serem desabrigados e retornarem para suas famílias. O sentimento de abandono é reatualizado a cada companheiro de abrigamento que parte. "Por que todos voltam para suas casas menos eu?".

É nesse sentido que se interpreta a terceira recomendação das OTSACA para a demanda das casas-lares: "crianças maiores ou adolescentes destituídos do poder familiar, que se encontram abrigados por longos períodos sem muitas perspectivas de adoção" (OTSACA, 2008, p. 41). São aqueles que provavelmente ficarão no abrigo até completarem 18 anos. Para estes, também não se coloca a tendência, mobilizada pela figura do educador residente, do 
abrigo se pôr no lugar da família. É, na realidade, uma vantagem ao invés de um problema já que eles não têm perspectiva de retorno familiar, seja a de origem, seja a substituta. Para estes casos, é importante que consigam encontrar no abrigo talvez não sua família, mas pelo menos uma família.

Em relação aos abrigos institucionais, as OTSACA apontam que

[...] caso haja demanda no município, e desde que haja na rede local abrigos para atendimento geral, podem ser desenvolvidos serviços especializados no atendimento a situações específicas, desde que tal atendimento não prejudique a convivência de crianças e adolescentes com vínculos de parentesco (irmãos, primos, etc.), não seja motivo de discriminação ou segregação, e se justifique pela possibilidade de atenção diferenciada a vulnerabilidades específicas. (OTSACA, 2008, p. 29)

Inicialmente, cabe salientar a proposta de "abrigos especializados no acolhimento de adolescentes sem vínculos familiares" (OTSACA, 2008, p. 29). As justificativas para um abrigo com essa especificidade são as mesmas que as da casa-lar:

[...] precisamos pensar e encontrar alternativas também para aquelas crianças que se tornam adolescentes nas instituições e precisam de um espaço mais privativo, podendo surgir dificuldades com a rotatividade acentuada de outras crianças e adolescentes na casa. (CARREIRÃO, 2003, p. 309)

Uma instituição com esse público teria como foco de trabalho o desenvolvimento da autonomia de seus atendidos, visto que estes provavelmente irão crescer dentro do abrigo e, quando completarem a maioridade, terão que sobreviver no mundo com os conhecimentos e as habilidades aprendidas no contexto da instituição.

Caracteriza-se pelo maior investimento no fortalecimento de vínculos comunitários, na ampliação do acesso à educação, qualificação profissional e progressiva autonomia do adolescente para o cuidado consigo mesmo e o cumprimento de suas responsabilidades. $\mathrm{O}$ atendimento deve favorecer a construção de projetos de vida e o fortalecimento do protagonismo, desenvolvendo gradativamente a capacidade do adolescente responsabilizarse por suas ações e escolhas. (OTSACA, 2008, p. 30)

Para este estudo, as instituições voltadas para esse público de longa permanência são o reconhecimento de que não se pode idealizar o retorno familiar. Afinal, precisa-se aceitar que a "volta para casa" não é uma opção para muitas crianças e adolescentes que vivem em abrigos. Apesar de ser o a prioridade para a maioria dos serviços de acolhimento institucional, 
não se pode esperar que ela tenha que ser obrigatoriamente a única resposta desses serviços para os casos que demandam sua intervenção.

Nesse sentido, como a questão do retorno familiar não se coloca com tanta ênfase nessas instituições, a equipe tem a possibilidade de desenvolver todos esses outros aspectos que, muitas vezes, se encontram ausentes nos abrigos com maior rotatividade de crianças e adolescentes.

Vale ainda destacar que esses serviços

[...] devem funcionar em estreita articulação com serviços de acolhida em República, visando a continuidade do apoio àqueles que após a maioridade precisarem de um serviço que os acolha e trabalhe a transição do abrigo para a autonomia e independência. Por meio de metodologia específica, esses serviços poderão manter Programas de Apadrinhamento Afetivo, com vistas à ampliação dos vínculos comunitários e construção de uma rede social de apoio para os adolescentes. (OTSACA, 2008, p. 31)

Com uma instituição voltada para essa especialidade, pode-se dar atenção àqueles que normalmente ficam esquecidos dentro dos abrigos convencionais por causa do constante foco desses últimos no desabrigamento.

Outro serviço especializado que este estudo considera essencial é a "casa de passagem", serviço que tem como objetivo

[...] oferecer acolhimento de caráter emergencial, com espaço adequado e profissionais preparados para receber a criança/adolescente em qualquer horário do dia ou da noite, diante de uma necessidade de acolhimento imediato e emergencial - como nos casos de internação hospitalar do único responsável pela criança, crianças perdidas, dentre outros - enquanto se realiza um estudo diagnóstico detalhado da situação de cada criança e adolescente. (OTSACA, 2008, p. 31)

Ora, se a proposta é possuir uma rede de serviços diferenciados para se adequarem melhor às especificidades de cada demanda, deve existir um local em que os casos que chegam são avaliados. Desse modo, considera-se que a casa de passagem não é somente uma instituição para o cuidado de casos que requerem uma proteção emergencial, ou seja, de curtíssima duração. Deve ser também a porta de entrada do sistema de abrigamento ${ }^{19}$, ou seja, o local para onde são encaminhados os casos com demanda de abrigo para, em "estudo

\footnotetext{
${ }^{19}$ Em relação ao conceito de "casa de passagem", é essencial salientar que, ainda que seja a porta de entrada para o abrigamento, a permanência abreviada nessas instituições não justifica o desrespeito a qualquer uma das exigências legais às quais os abrigos devem responder.
} 
diagnóstico detalhado", ser avaliada a possibilidade de manutenção do convívio familiar ou necessidade de afastamento do mesmo.

Ao longo da exposição dos tipos de abrigos, tem-se procurado marcar a ideia de "foco de trabalho" como um elemento justificador das segmentações propostas, partindo do pressuposto da dificuldade (ou mesmo impossibilidade) de uma única instituição de acolhimento ser capaz de dar conta de todas as complexidades que são de sua atribuição. Nessa linha, o foco de trabalho de uma casa de passagem deve, por exemplo, simplesmente deixar de lado a questão educacional (no sentido de buscar matricular seus atendidos e alocar esforços para acompanhar o seu desempenho), já que as crianças e os adolescentes que ali se encontram, apenas permanecerão por um curto período de tempo na instituição. ${ }^{20}$

Em compensação, todos os esforços e as energias devem se voltar para a família de origem (nuclear ou extensa) da criança ou do adolescente, ou, ainda, pessoas da comunidade que lhe sejam significativas, na tentativa de reverter o abrigamento. Estar na casa de passagem ainda não é estar abrigado. É um período de transição até que se defina o melhor encaminhamento para cada caso.

É importante perceber que, se nos abrigos de longa permanência, o trabalhador que se destaca como o mais importante para o bom desenvolvimento do trabalho é o educador/cuidador, na casa de passagem, esse foco se desloca para as equipes técnicas que realizarão de modo intensivo o contato com os familiares das crianças e adolescentes acolhidos. Deve-se pensar, inclusive, que o número de técnicos nesse equipamento deverá ser necessariamente maior.

Além desse foco na tentativa de reintegração familiar imediata, outro direcionamento essencial à equipe de uma casa de passagem é a metodologia de acolhimento inicial, ou seja, as intervenções que devem ser feitas no momento da chegada de um novo abrigado, levando em consideração que esse é um momento de peculiar situação de vulnerabilidade, devem incluir:

[...] i. destinar espaço físico especificamente para o acolhimento daqueles que estão chegando, uma vez que o acolhimento pode ocorrer a qualquer momento, inclusive no período noturno; ii. dispor de profissionais qualificados e capazes de dialogar sensivelmente com crianças e adolescentes nesse momento que envolve ruptura, incerteza, insegurança e

\footnotetext{
${ }^{20}$ Tomando por base a definição das próprias OTSACA que consideram "acolhimento emergencial" como o período de até um mês de abrigamento, sugerimos que o prazo máximo de permanência da criança ou adolescente na casa de passagem seja também de um mês.
} 
transição, auxiliando a significar a vivência do afastamento provisório. (OTSACA, 2008, p. 32)

Poderíamos ainda acrescentar: esclarecimentos a respeito do que é um abrigo, apresentação do espaço físico da casa e dos demais atendidos, um trabalho de acolhimento e apoio em relação à violência sofrida etc. Com esse sistema, a chegada e a saída constante de novos atendidos não atrapalha a rotina das crianças e dos adolescentes que se encontram acolhidos, como aconteceria em um "abrigo comum".

Por fim, vale destacar que

[...] a organização de serviços de acolhimento emergencial não significará, em nenhuma hipótese, negligência ao princípio da excepcionalidade, ao qual também devem se submeter, e que a criança e o adolescente só devem ser encaminhados para esse serviço quando não for possível realizar tal estudo mantendo-os com a família de origem (nuclear ou extensa) ou pessoas significativas da comunidade. (OTSACA, 2008, p. 32)

Ainda em relação às casas de passagem, alguns cuidados devem ser tomados. Principalmente nas redes de abrigos formadas majoritariamente por instituições privadas, como é o caso da cidade de São Paulo, por exemplo, percebe-se nitidamente que serviços de triagem têm sérias dificuldades de encaminhamento dos casos considerados mais difíceis. É o que fica claro a partir da experiência das Casas de Recepção e Encaminhamento da Febem/SP que apontou

[...] como maior dificuldade para o desenvolvimento de suas funções: a falta de vagas em abrigos da rede e o estabelecimento de critérios de elegibilidade que dificultam o encaminhamento de adolescentes, principalmente se tiverem histórico de vivência de rua, drogadição, homossexualismo, portadores de deficiência mental ou transtornos mentais. (AASPTJ-SP/NCAPUCSP/SAS/FUNDAÇÃO ORSA, 2003, p. 58)

Fica claro que, mesmo uma rede supostamente de proteção tem seus pontos de estrangulamento, representados pela exclusão de certos atendidos. Dessa experiência pode-se depreender que, para que uma casa de passagem faça sentido dentro da rede de abrigos mais ampla, os critérios de elegibilidade precisam ser pactuados coletivamente e não apenas pela instituição que vai receber a criança ou o adolescente. Caso contrário, 
[...] a permanência nas casas [de passagem], que deveria ocorrer por breve período, tendo em vista a função de recepção e encaminhamento e não de abrigamento, acaba se prolongando para os segmentos que encontram maior resistência de aceitação na rede de atendimento. (AASPTJ-SP/NCAPUCSP/SAS/FUNDAÇÃO ORSA, 2003, p. 58)

Na realidade, o oposto também não é desejável, ou seja, um sistema no qual apenas as instituições de triagem determinam os critérios de encaminhamento dos casos. Nessa situação inversa, as instituições de triagem transformam-se em lugares de poder, já que poderiam decidir soberanamente os encaminhamentos de cada caso.

O risco que se corre em ambos os processos é transformar certas instituições da rede no destino certo daqueles que são excluídos pelo restante do sistema, criando "lugares malditos".

No caso de São Paulo,

[...] observa-se que sendo um serviço direto do poder público, que não coloca critérios restritivos para receber crianças e adolescentes [...] [são as casas de triagem que] acabam concentrando uma população de difícil aceitação nos abrigos, sem muitas alternativas de resolução para um problema que pertence ao sistema de abrigamento como um todo. (AASPTJSP/NCA-PUCSP/SAS/FUNDAÇÃO ORSA, 2003, p. 59)

Como conclusão, para as casas de passagem funcionarem de modo adequado, impõese a necessidade da pactuação coletiva por toda a rede de abrigos do fluxo de encaminhamentos a ser estabelecido.

O texto das OTSACA coloca ainda como um tipo possível de abrigo aqueles "especializados no acolhimento de adolescentes grávidas ou com filhos" (OTSACA, 2008, p. 30), com uma metodologia que teria como foco de trabalho a vinculação mãe-criança, sem esquecer que propiciar às "mães adolescentes os direitos inerentes a ambas as condições: maternidade e adolescência" (OTSACA, 2008, p. 30).

O presente estudo não está certo a respeito da necessidade de um abrigo especificamente voltado para esse fim. Obviamente, poderia se pensar, como se sugere nas OTSACA, na necessidade de "oferecer orientação especializada nas questões referentes à sexualidade e aos direitos reprodutivos" (OTSACA, 2008, p. 30). Ou seja, esta seria uma instituição na qual o trabalho em torno da sexualidade deveria ser mais intenso.

No entanto, consideramos essa uma falsa questão. O fato de essas adolescentes estarem grávidas ou já terem seus filhos não significa que têm mais necessidade de orientação 
nos temas ligados ao exercício sadio da sexualidade do que aquelas que não têm filhos. $\mathrm{Na}$ realidade, todo adolescente demanda esse tipo de orientação, inclusive como forma de prevenção. Não vejo porque uma casa de longa permanência ou mesmo uma casa-lar, com seus ambientes mais próximos do modelo familiar e com maior estabilidade e personalização no atendimento, não poderiam dar conta das questões envolvidas em uma gravidez na adolescência ou mães adolescentes com filhos.

Deixou-se para o final, aquela que se considera a mais polêmica das recomendações a respeito de tipos diferenciados de abrigos: aqueles "especializados no atendimento a crianças e adolescentes em situação de rua" (OTSACA, 2008, p. 31).

Afirma-se ser essa proposta polêmica, pois ela parece seguir na contramão do que foi apresentado até o momento, elegendo um perfil supostamente mais problemático e que, por isso, não poderia ser misturado com os demais.

Segundo as OTSACA, este seria um serviço que atuaria

[...] junto ao processo de "saída da rua". Caracteriza-se por intenso fluxo de entrada e saída, incluindo até mesmo entradas no período noturno, que podem ser motivadas, inclusive, pela demanda espontânea da criança e do adolescente. Funciona como um serviço de transição entre a rua e a reintegração familiar ou encaminhamento para um serviço de acolhimento mais estável. (OTSACA, 2008, p. 31)

Este estudo seria totalmente contra uma proposta de um abrigo especializado em crianças e adolescentes em situação de rua. No entanto, parece-nos que a proposta que as OTSACA coloca não é propriamente a de um abrigo em seu sentido estrito, ou seja, o de moradia alternativa. Configura-se muito mais como uma "casa de passagem", na medida em que é um equipamento de transição entre a rua e a família ou um abrigo. Desse modo, este trabalho considera a proposta interessante, pois ela não parece criar um "lugar de malditos", um lugar feito para esconder determinado perfil indesejado, impedindo-o de se misturar com os demais. Ao contrário, parece uma instituição que trabalha para, ao final de um processo que se pode chamar de "saída da rua", incluir esses meninos e meninas nos abrigos convencionais ou, caso seja possível, diretamente em sua família.

Segundo a definição do Plano Nacional de Convivência Familiar e Comunitária (PNCFC), meninos e meninas de rua são definidos como "crianças e adolescentes que fazem ou estão em vias de fazer da rua um espaço de referência, seja para subsistência, trabalho ou moradia, mantendo ou não vínculo familiar” (2006, p. 55). A partir dessa definição, fica claro 
que a questão de crianças e adolescentes em situação de rua pode requerer a intervenção das instituições de abrigamento. Isso porque existem tanto meninos de rua que apresentam vínculo familiar como os que não o possuem. Esses cujos vínculos encontram-se rompidos seriam os casos com demanda de abrigo.

No entanto, apesar da necessidade de abrigamento diagnosticada, a ideia é que "tanto o trabalho de aproximação quanto o de acolhimento propriamente dito tenham como objetivo re-introduzir a criança e o adolescente gradativamente em uma rotina doméstica" (OTSACA, 2008, p. 31) sem a qual nem o encaminhamento à família nem ao abrigo obteriam sucesso. Mesmo a rotina e a dinâmica de um abrigo comum podem ser insuportáveis para alguém que já possui a rua como referência.

Acreditamos que sem essa etapa intermediária, a adaptação da criança ou adolescente ao abrigo, e vice-versa, é extremamente complicada. Nos termos acima descritos, ou seja, como transição e não como permanência, somos favoráveis a uma instituição especializada nesse atendimento, pois parece que a situação de rua demanda intervenções que estão fora das atribuições de um "abrigo comum" (como, por exemplo, ir atrás de uma criança ou adolescente quando ele foge e volta para as ruas).

Parece-nos muito com o trabalho realizado, por exemplo, pelo Projeto Meninos e Meninas de Rua (PMMR), mas com a possibilidade de se dormir na instituição por algum tempo, o qual também deve ser curto.

Ainda e

[...] diferentemente dos demais serviços de acolhimento, esse serviço costuma ofertar em suas dependências atividades lúdicas, culturais e outras, organizadas como oficinas, como parte integrante de uma estratégia para a aproximação gradativa e construção de um vínculo de confiança com a criança e o adolescente. (OTSACA, 2008, p. 31)

Defendemos que uma especialização como essa se justifica na medida em que a rotina proposta nessas instituições (oficinas etc.) seria totalmente diferente da de um "abrigo comum" e, na realidade, incompatível com ele. Imagine morar em um local onde todos os dias acontecem as mais diferentes aulas: dança, música, capoeira, grafite, teatro etc. Inclusive, essa configuração também não se coaduna com a "aparência residencial" que é exigida para os serviços de acolhimento institucional. ${ }^{21}$

\footnotetext{
${ }^{21}$ Mais adiante um item será especialmente dedicado a esse tema.
} 
Outra diferença essencial (e que seria impossível de se realizar no âmbito de um abrigo) é que essa instituição especializada em meninos e meninas em situação de rua teria como um de seus focos de trabalho a busca ativa de sua demanda e não apenas a passividade (no sentido de sempre receber encaminhamentos) que é característica dos "abrigos comuns". Em outras palavras, seria um serviço que deveria contar com educadores de rua que abordam as crianças e os adolescentes no ambiente onde elas estão, com o intuito de sensibilizá-las a irem até o "abrigo especializado" e darem continuidade ao trabalho.

De maneira geral, consideramos ter mostrado alguns modelos de especialização do atendimento em abrigos que não são motores de segregação, mas simplesmente vetores para o estabelecimento de diferentes focos de trabalho. Partindo do fato de que nenhuma instituição consegue dar conta de tudo, alguns recortes podem ser essenciais para a conquista de um trabalho produtivo. A inovação das propostas das OTSACA reside no fato de não mais se basear em perfis de crianças e adolescentes, mas principalmente no tempo de permanência na instituição, principalmente pensando em uma divisão entre abrigos para casos de curta e longa permanência. Nos primeiros, o foco se mantém rigorosamente na reintegração familiar, quando essa se constituir na melhor alternativa para a criança ou o adolescente. No segundo, constituído de abrigos para crianças e adolescentes sem vínculos familiares e que provavelmente permanecerão no abrigo até a maioridade, o foco passa a ser a construção da autonomia dessa criança e adolescente. É importante perceber que a ideia de "foco" não traz consigo uma restrição estanque das funções. Obviamente que um serviço de curta permanência inevitavelmente terá que atuar no sentido da construção da autonomia de seus atendidos e que um abrigo de longa permanência nunca desistirá da sua função de reintegração familiar. No entanto, com um foco bem definido, cada uma dessas instituições poderá desenvolver melhor o trabalho ao qual se propôs.

São diferenciações que não criam "guetos" ou "perfis malditos". Caracterizam melhor a demanda de acordo com certas necessidades específicas de cada subgrupo sem criar depósitos daqueles que ninguém quer, lembrando que, quando pensamos em política pública, devemos ter em mente que são as instituições que devem se adaptar à demanda e não a demanda às instituições já existentes.

Para finalizar, o presente estudo gostaria de indicar que o processo de "segmentar sem segregar" ainda não está completo. É importante lembrar que, principalmente nas grandes metrópoles, a regionalização do atendimento é um critério essencial a ser levado em consideração quando se depara com a questão: para onde devo encaminhar tal caso? Esse 
processo de regionalização será melhor discutido em um item especialmente dedicado ao assunto. No entanto, fica a sugestão de uma rede de abrigos que, particularmente, considera-se a ideal: casas divididas por território e com projetos de atendimento diferenciado, seguindo as propostas apontadas acima.

\subsubsection{O número de vagas: um posicionamento contra o atendimento massificado}

Outro ponto de extrema relevância que o Levantamento Nacional vem descortinar é que a baixa qualidade dos serviços oferecidos não poderia ser tributada principalmente ao fato dos abrigos atenderem a um alto número de crianças e adolescentes por unidade ou mesmo um número acima de sua capacidade. Isso porque $57,6 \%$ das instituições pesquisadas atendem até 25 pessoas e 64,2\% funcionam com um número de abrigados abaixo do número de vagas (cf. IPEA, 2003, p. 3).

Ainda que $41,9 \%$ dos serviços de acolhimento institucional ofereçam um atendimento massificado (acima de 25 abrigados por unidade), pelo menos em nível nacional, o que se pode depreender das estatísticas do Levantamento Nacional é que a superlotação não seria um problema da maioria dos abrigos, o que os aproxima da recomendação do Estatuto, que prevê (art. 92, inc. III do ECA) o atendimento personalizado e em pequenos grupos, ainda que o texto legal não especifique qual o número exato de abrigados que corresponderia a um "pequeno grupo". Contudo, embora essa regulamentação ainda não tenha sido legalmente fixada, existem alguns textos indicativos de que um pequeno grupo pode ser definido como algo que varie entre 20 a 25 atendidos por unidade de abrigo ${ }^{22}$.

No entanto, a porcentagem de $41,9 \%$ ainda corresponde a um elevado número de instituições, indicando que a capacidade de atendimento é uma importante característica a ser considerada no reordenamento dos abrigos.

Contudo, este estudo considera que a realidade estudada pelo Levantamento Nacional nesse ponto pode ser um pouco diferente da apontada pela pesquisa. Isso porque, quando analisamos a questão da quantidade de vagas, uma análise por unidade de acolhimento, como

22 MINISTÉRIO DA PREVIDÊNCIA E ASSISTÊNCIA SOCIAL. Subsídios para o ordenamento $e$ financiamento dos serviços de abrigo. Brasília, 2000; CONSELHO MUNICIPAL DOS DIREITOS DA CRIANÇA E DO ADOLESCENTE - RJ. Política de abrigo para crianças e adolescentes do município do Rio de Janeiro. Rio de Janeiro, setembro de 2001. 
a descrita acima, pode ser enganadora. Mesmo que a maioria dos abrigos atenda em pequenos grupos, isso não significa que a maioria das crianças e adolescentes abrigadas esteja acolhida em instituições de pequeno porte, pelo simples fato de que as grandes instituições reúnem muitos atendidos.

É o caso da cidade de São Paulo, onde $100 \%$ dos abrigos conveniados com a SAS, 54,2\% dos conveniados com a Secretaria Estadual de Assistência e Desenvolvimento Social (SEADS) e 76,9\% dos não conveniados são de pequeno porte (cf. AASPTJ-SP/NCAPUCSP/SAS/FUNDAÇÃO ORSA, 2003, p. 90) e, no entanto, mais da metade (por volta de $56 \%$ ) das crianças e adolescentes abrigados encontram-se em instituições com mais de 25 atendidos (cf. AASPTJ-SP/NCA-PUCSP/SAS/FUNDAÇÃO ORSA, 2003, p. 121). Em outras palavras, se se pretende conhecer a verdadeira situação do atendimento massificado em abrigos, o levantamento a ser feito deve seguir o padrão da pesquisa paulista, qual seja, medir a porcentagem de crianças e adolescentes abrigados em instituições com mais de 25 atendidos e não o índice de abrigos que trabalha com um número de acolhidos inferior a esse.

Os impasses nesse ponto tendem a se tornar difíceis de resolver, pois a questão do número de vagas envolve necessariamente a própria arquitetura do abrigo. Em alguns casos, os espaços característicos dos antigos orfanatos, com terrenos amplos e grandes edificações, são próprios, dificultando as tentativas de transformação.

Diante dessa situação, muitos abrigos estão optando por soluções que, apesar de minimizar os efeitos do atendimento massificado, ainda parecem muito distantes do que propõe o ECA, tais como: dividir os grandes edifícios em núcleos menores ou ainda a construção de pequenas casas dentro do espaço da instituição.

\footnotetext{
Essa questão leva ao seguinte questionamento: será que em vez de investir esforços artificiais para aproximar-se do modelo proposto pelo ECA em relação aos abrigos, não seria mais adequada a mudança do tipo de programa de atendimento? Algumas instituições que estão fora dos padrões de atendimento como abrigo, poderiam realizar um bom atendimento como creches e centros de juventude, o que, inclusive poderia representar trabalho preventivo ao abrigamento. (AASPTJ-SP/NCA-PUCSP/SAS/FUNDAÇÃO ORSA, 2003, p. 92)
}

Tal seria o destino possível para os antigos orfanatos ainda em atividade: aquelas mesmas instituições que outrora encarceravam crianças e adolescentes, hoje se dedicariam ao trabalho de prevenção à institucionalização. 
Retomando a questão da redução do número de atendidos por unidade, apesar do imenso avanço alcançado nos últimos anos, não se pode perder de vista o ideal: a semelhança com um ambiente residencial. Entretanto, vale ressaltar que o modelo de "ambiente residencial" não deve ser buscado exclusivamente na configuração da família nuclear. Serão discutidas as questões que envolvem as famílias que possuem filhos abrigados em outro momento do texto, no entanto, é preciso pontuar aqui que não se pode tomar a família nuclear como o ideal a ser seguido e passar a tentar reproduzir dentro do abrigo todas as suas características, tanto em termos de seu número médio de pessoas como de sua dinâmica afetiva. Nesse trecho da investigação, trata-se de pensar no número de pessoas que costumeiramente habitam, de modo saudável, o espaço de uma casa.

A questão da aparência residencial é complexa, passando inclusive por importantes considerações arquitetônicas, que também serão alvo de discussão em outro momento do trabalho. Aqui, está-se analisando a parcela desse princípio que passa pela sua relação com a dinâmica de uma família. Sendo assim, se o "ambiente residencial” deve se aproximar de uma aparência familiar, não se está autorizado a especificar apenas um modelo de família a ser perseguido. Mas, em qualquer dos muitos sistemas familiares existentes, alguns limites podem ser estabelecidos. Se um serviço de abrigo deve se assemelhar a um ambiente residencial, perguntamos: qual casa, em qualquer dos múltiplos modelos alternativos de família, possui 25 pessoas morando nela, além dos funcionários que ali trabalham diariamente? Portanto, devemos ter em mente que a redução do número de abrigados por equipamento é um princípio a ser perseguido continuadamente até uma quantidade que realmente propicie um ambiente acolhedor e um atendimento personalizado. Baseado em experiência pessoal, arrisco que tal número giraria em torno de 8 a 10 abrigados.

\subsubsection{A regionalização do atendimento}

Mesmo sendo a institucionalização muitas vezes a medida mais recomendada, existem critérios importantes para se diminuir o impacto desse processo. O PNCFC aponta que "se o afastamento do convívio familiar for necessário, as crianças e adolescentes devem, na medida do possível, permanecer no contexto social que lhes é familiar" (2006, p. 32). 
Caso o direito à convivência familiar deva ser rompido em prol de um bem maior, deve-se ter o cuidado de preservar o direito à convivência comunitária, sendo então o ideal que a criança/adolescente seja encaminhado para um abrigo próximo à sua residência de origem. A permanência na própria comunidade diminui a sensação de desenraizamento, vivenciada por toda criança e adolescente que entra para uma instituição de acolhimento. Nesse sentido, falar de convivência comunitária ou trabalho comunitário sem abrigos regionalizados torna-se praticamente impossível.

O processo de regionalização é um movimento pelo qual a área da Saúde já passou (com o questionamento do modelo hospitalocêntrico e proposta das UBSs, por exemplo) e que a própria Assistência Social incorporou em parte (com os Centros de Referência de Assistência Social - CRAS, por exemplo). No caso da saúde, ao invés de grandes hospitais localizados nos centros das cidades, desenvolveu-se a proposta de implementar pequenas unidades de saúde localizadas em território, ou seja, dentro das comunidades periféricas, com a função de realizar os serviços médicos de menor complexidade, mas que, devido ao seu número excessivo, atolavam os grandes centros hospitalares.

$\mathrm{Na}$ Assistência Social, após a formulação do Sistema Único da Assistência Social (SUAS, cf. a NOB-SUAS/2005), houve o início de um movimento similar. Os CRAS são a presença da Assistência Social em território, ou seja, em cada comunidade. São responsáveis pelo que a política nacional chama de proteção social básica e exemplos de um serviço que possui a regionalização como sua característica fundante, servindo, inclusive, como uma referência articuladora da rede de apoio local. O CRAS, em relação ao abrigamento, deve exercer uma importante tarefa de prevenção à violência.

No caso dos abrigos, defende-se que suas redes também sejam organizadas de acordo com a territorialização, principalmente nos grandes centros urbanos. No entanto, algumas ressalvas necessitam ser feitas, advindas da própria especificidade da demanda que os abrigos acolhem. Trata-se de uma territorialização com restrições, uma vez que alguns casos que os serviços de acolhimento institucional atendem necessitam justamente, pelo menos em um primeiro momento, de um afastamento entre vítima e agressor e, nesse caso, o distanciamento espacial é um recurso importante. É o caso, por exemplo, das violências sexuais, tanto o abuso como a exploração, nas quais a ruptura imediata do vínculo violento muitas vezes é a ação mais recomendada.

Para Fávero, Vitale \& Baptista (2008), o fato de 94\% das pessoas de referência das crianças e adolescentes abrigados residirem no mesmo município (São Paulo) dos abrigos que 
acolheram seus filhos, "confirma a busca da efetivação do ECA, no sentido de que o acolhimento institucional, quando necessário, deve ocorrer na mesma localidade de residência dos familiares" (p. 97).

O presente estudo discorda. Especialmente em relação aos grandes centros urbanos, mesmo que o abrigo e a família estejam no mesmo município, isso não garante que a instituição de acolhimento seja facilmente acessível a esses familiares. As grandes cidades são unidades espaciais imensamente maiores do que as regiões onde efetivamente a vida dessas famílias se desenrola. Seguindo a lógica territorial, os abrigos devem estar localizados não simplesmente na mesma cidade das famílias das crianças e adolescentes que acolhem, mas também onde suas vidas acontecem.

Para exemplificar a necessidade da regionalização do atendimento em abrigos, salvo os casos expostos anteriormente, pode-se citar alguns dados trazidos pela pesquisa da AASPTJ-SP/NCA-PUCSP/SAS/Fundação Orsa (2003): como, por exemplo, que 39\% das mães que moram na zona oeste têm seus filhos abrigados na zona leste. Para se ter a noção da inversão na lógica do território, essa porcentagem é mais do que o dobro da que representa o número de mães que possuem seus filhos abrigados na própria zona oeste (16\%). As porcentagens de mães moradoras da zona oeste com filhos abrigados nas zonas norte e sul são de $33 \%$ e $11 \%$, respectivamente (p. 205). Das mães que moram na região central, nenhuma possui seus filhos abrigados na própria região (p. 208).

Abrigos regionalizados facilitariam as visitas dos familiares nos abrigos, uma vez que estes não mais teriam que atravessar a cidade para ver seus filhos. Diante desses dados é possível contextualizar as verbalizações constantes de pais e mães que dizem não possuir dinheiro para as visitas no abrigo. O trabalho de visitas domiciliares, bem como o encaminhamento dos atendidos para passarem o fim de semana com seus familiares, também seriam imensamente facilitados pelo encurtamento das distâncias espaciais. Em outras palavras, regionalização significa incentivo à preservação dos vínculos familiares.

Mas a noção de território não remete apenas a esse tipo de vantagens objetivas, pois pressupõe também o modo como cada localidade é experienciada por aqueles que nela residem, ou seja, a maneira como o espaço é vivido. Desse modo, a regionalização é uma necessidade essencial se verdadeiramente desejarmos que os abrigos consigam efetivar o direito à convivência comunitária, por exemplo. 
A pesquisa apontou que se por um lado as regiões sul e leste são as que apresentam maior quantidade de mães com filhos abrigados, por outro, são essas regiões que possuem maior quantidade de abrigos da cidade de São Paulo, o que sugere a possibilidade de uma relação equilibrada entre a demanda e a oferta de serviços na perspectiva do atendimento regionalizado. (AASPTJ-SP/NCA-PUCSP/SAS/FUNDAÇÃO ORSA, 2003, p. 208)

A "possibilidade" realmente existe, mas não é concretizada. Se a infraestrutura já se encontra equilibrada na sua relação entre oferta e demanda, ou seja, existe mais oferta onde há maior demanda, a não-regionalização parece ser totalmente uma questão de cultura das instituições e da política pública. Para se efetivar a regionalização não são necessárias grandes cifras financeiras. Como não se pode determinar uma política de transferências em massa, a estratégia seria a regionalização dos novos encaminhamentos aos abrigos. Trata-se de uma mudança de paradigma, uma mudança no histórico descaso ou falta de profissionalismo com que se direciona uma criança ou adolescente para um abrigo.

Mas, no movimento contrário às vantagens e possibilidades agora enunciadas, os dados da regionalização no atendimento em abrigos, pelo menos no município de São Paulo, indicam que, por mais que se afirme o oposto, proteger ainda é simplesmente afastar da família.

Vale destacar ainda que a regionalização dos serviços de abrigamento deve ser pensada levando-se em consideração a relação destes com o Poder Judiciário, uma vez que

[...] nem sempre os processos das crianças e adolescentes estão concentrados nas VIJs [Vara da Infância e da Juventude] correspondentes à jurisdição dos abrigos. Este fato decorre, muitas vezes, da necessidade de abrigamento e da ausência de vagas nos abrigos de abrangência da VIJ responsável pelo caso. Com isso, a criança ou adolescente acaba sendo encaminhado para local distante da moradia dos familiares, contrapondo o que está determinado por lei. (AASPTJ-SP/NCA-PUCSP/SAS/FUNDAÇÃO ORSA, 2003, p. 142)

Dados levantados em São Paulo, como, por exemplo, o de que $71 \%$ das crianças e adolescentes acolhidos em abrigos sob a jurisdição da VIJ Ipiranga possuem processo em outras VIJs da capital (cf. AASPTJ-SP/NCA-PUCSP/SAS/FUNDAÇÃO ORSA, 2003, p. 143), indicam que também o Judiciário está distante da adequação ao princípio da regionalização.

Especificamente em relação à cidade de São Paulo (mas supõe-se que tal fenômeno também deve ocorrer em outros aglomerados urbanos) "verifica-se nos abrigos da capital certa concentração de crianças e adolescentes provenientes de outras comarcas, sendo 
constatado que a maior parte refere-se à Grande São Paulo" (AASPTJ-SP/NCAPUCSP/SAS/FUNDAÇÃO ORSA, 2003, p. 144).

Tal como indicado anteriormente, parece existir nos grandes centros urbanos um processo de atração da demanda das cidades menores ao seu redor, como se fosse o efeito de um imã, agravando ainda mais as condições de vida nas grandes metrópoles. Tal situação pode ocorrer por uma série de fatores como, por exemplo, a maior oferta de serviços assistenciais nos grandes conglomerados urbanos.

\subsubsection{A relação do abrigo com a comunidade}

Esse trecho do trabalho será dedicado ao exame da relação dos abrigos com as pessoas e instituições do seu entorno, uma relação quase sempre difícil e permeada de incompreensões e preconceitos.

\subsubsection{Sob a sombra das instituições totais}

Um dado bastante ambivalente apontado pelo Levantamento Nacional é o de que $60 \%$ dos abrigos oferecem outros tipos de atividades para crianças e adolescentes da comunidade, tais como complementação escolar, apoio psicológico/social para famílias carentes, cursos de profissionalização, escolas e creches (cf. IPEA, 2003, p. 3).

Tal situação, muitas vezes entendida como algo positivo, marca, na realidade, uma confusão em torno do direito à convivência comunitária. À primeira vista, este poderia ser entendido como uma continuação do direito à convivência familiar, caso se pense no desenvolvimento infantil. Isso porque

[...] a partir da sua entrada na educação infantil ou no ensino fundamental, a criança expande seu núcleo de relacionamentos para além da família. [...] A partir da relação com colegas, professores, vizinhos e outras famílias, bem como da utilização das ruas, quadras, praças, escolas, igrejas, postos de saúde e outros, crianças e adolescentes interagem e formam seus próprios grupos de relacionamento. [...] Os espaços e as instituições sociais são, 
portanto, mediadores das relações que as crianças e os adolescentes estabelecem, contribuindo para a construção de relações afetivas e de suas identidades individual e coletiva. (PNCFC, 2006, p. 32)

Percebe-se mais uma vez o movimento da política pública dirigida às crianças e adolescentes de se aproximar e tentar garantir não só as necessidades mais concretas e imediatas, como as necessidades de saúde, por exemplo, que estariam ligadas ao direito mais fundamental de todos, que é o direito à vida, mas também de necessidades psicossociais ligadas, por exemplo, ao direito à convivência comunitária.

Mas, na realidade, em relação aos abrigos, dos apontamentos feitos anteriormente, nada nos permite concluir que aquelas atividades devam se desenvolver dentro das instituições. O direito à convivência comunitária tem uma ligação muito mais profunda com o local onde as atividades acontecem do que com as atividades em si. Isso por que ele traz em seu bojo a tentativa de transformá-los em verdadeiros mecanismos de inclusão, pois

[...] durante muitos anos a colocação de crianças e adolescentes em instituições se configurava como instrumento de exclusão, visto que funcionavam como verdadeiras "prisões", onde todas as atividades e serviços eram desenvolvidos dentro dos muros das entidades - educação, atenção à saúde, lazer (quando existia). O Estatuto da Criança e do Adolescente indica como princípio a ser seguido no atendimento em abrigos a participação na vida comunitária, que deve ser concretizada, de um lado, pela garantia de acesso dos abrigados às políticas básicas e aos serviços oferecidos para a comunidade em geral. Em segundo lugar, por meio da participação das crianças e adolescentes em atividades externas de lazer, esporte, religião e cultura, em interação com a comunidade circundante. Isso proporciona contato com a realidade externa, evitando-se a alienação e a inadequação à vida em comunidade. (IPEA, 2003, p. 13)

Nesse ponto, o Levantamento Nacional mostra que 34,1\% dos abrigos pesquisados oferecem pelo menos um dos seguintes serviços exclusivamente dentro da instituição: creche, ensino regular, profissionalização para adolescentes, assistência médica e odontológica, atividades culturais, esportivas, de lazer e assistência jurídica (IPEA, 2003, p. 13). É um quadro preocupante, pois indica, mais uma vez, que a sombra das instituições totais ainda paira sobre os abrigos brasileiros.

Novamente, aqui, tem-se, por um lado, um quadro com instituições de alta capilaridade, ou seja, de grande inserção nas comunidades em que estão inseridas. Por outro, entidades que desenvolvem muitos serviços diferentes e complementares entre si, nos quais a criança ou o adolescente abrigado possa ter grande parte de suas necessidades atendidas 
dentro de uma mesma organização, aumenta a sensação de separação entre o interior da instituição e o mundo fora dela.

Um dos efeitos subjetivos desse distanciamento entre o mundo institucional e mundo "real" é o desenvolvimento de um verdadeiro abismo simbólico entre ambos, gerando uma relação de dependência da criança ou do adolescente em relação à instituição, já que, com o passar do tempo, os códigos e signos institucionais serão os únicos que esses "internos" serão capazes de ler. O mundo extramuros passa a ser difícil de ser decifrado, pois apresenta regras e costumes que não mais lhes são familiares. O que era conhecido passa a ser desconhecido e, portanto, temido.

Tais abrigos apresentam, ainda, um ranço do que Goffman (1974) chamou de "instituições totais" ao descrever os manicômios, conventos e prisões: instituições que absorvem dentro de si todas as esferas da vida de um sujeito. Se uma criança mora, estuda, pratica esportes e vai ao médico dentro de uma mesma instituição, isso significa que a maioria de seus referenciais vai se desenvolver a partir daquela realidade, que pode ser boa ou ruim. Esse não é o ponto da discussão. O foco é que a realidade institucional, boa ou ruim, é sempre artificial, uma vez que não apresenta a diversidade e a complexidade da realidade extramuros. O mundo é diverso e uma das maiores riquezas para uma criança é ser apresentada a essa pluralidade de modelos. Uma instituição, por mais aberta que seja, é sempre conservadora nesse sentido, pois ela precisa de certa estabilidade de princípios e normas para funcionar. É dessa estabilidade referencial que advém seu caráter artificial.

A partir dessas reflexões, não surpreende que a pesquisa da AASPTJ-SP/NCAPUCSP/SAS/Fundação Orsa (2003) tenha apontado, ainda que pequena, a existência de uma parcela de adultos vivendo nos abrigos (p. 168). São jovens que, ao completarem 18 anos, permaneceram no abrigo por não terem aonde ir ou, pode-se arriscar, por não "saberem" aonde ir, ou seja, por não conseguirem se adaptar ao mundo fora da instituição. Ou, ainda, como apontou a pesquisa de Cunha (1999), a qual revelou que muitos adolescentes, após o desabrigamento, foram viver nas ruas. De um jeito ou de outro, permanecendo no abrigo ou indo parar nas ruas, o que se salienta é o fato desses jovens não conseguirem viver sozinhos, de modo autônomo.

Essa situação reitera a necessidade de investimento, de esforços da rede de atendimento para que crianças e adolescentes vivam em meio familiar. Pois, ainda que o abrigo se empenhe no processo de fortalecimento da autonomia do adolescente, por meio da escolarização, profissionalização ou mesmo 
intermediação na busca de emprego, dificilmente aqueles que não contam com retaguarda familiar poderão viver longe da tutela institucional. (AASPTJ-SP/NCA-PUCSP/SAS/FUNDAÇÃO ORSA, 2003, p. 169)

Existe um limite do que é possível superar vivendo em uma instituição. Por mais esforços que se faça, por melhor que seja o atendimento oferecido, uma instituição será sempre uma instituição, ou seja, será sempre uma realidade artificial.

Além disso, existem limites também para o quão autônomo um adolescente pode ser, no sentido de que não se pode exigir que ele se transforme em adulto precocemente. Em outras palavras, não se pretende apontar qualquer tipo de incapacidade inerente a esses jovens. O limite está no modelo de atendimento (e com isso também não se quer dizer que esse modelo é necessariamente ruim), que não fornece tudo o que esses adolescentes necessitam para se desenvolverem integralmente.

Como um caso extremo dessa situação, pode-se relatar a história de um menino cujo desabrigamento foi acompanhado por este estudioso e que parece ser um exemplo eloquente do fato de que a institucionalização prolongada tende a gerar no sujeito uma dependência psíquica da instituição. W. foi desabrigado por maioridade, depois de um longo período em diversos abrigos. Tinha um histórico de uso de drogas, mas não de envolvimento com a criminalidade. Sua saída do abrigo foi carregada de angústia para ambos os lados, tanto para o adolescente como para os profissionais do abrigo. Isso porque, a princípio, o jovem não tinha para onde ir e estava muito difícil conseguir uma vaga em alguma república.

Por fim, depois de um exaustivo trabalho de sensibilização, uma tia distante aceitou acolher temporariamente o adolescente para que ele se organizasse, ou seja, arrumasse um emprego e conseguisse se sustentar sozinho. O abrigo se propôs a acompanhar e auxiliar W. nesse processo. No entanto, nem bem havia passado dois dias que W. fora encaminhado para a casa de sua tia, ele retornou à porta do abrigo carregado de drogas (maconha, alguns papelotes de cocaína e tíner), oferecendo-as explícita e gratuitamente, no meio da rua, a todos os abrigados que o cercaram para cumprimentá-lo. Logo se formou uma grande roda ao seu redor. Inclusive as crianças pequenas pediam aos educadores que permitissem sua saída para conversar com W., o que, obviamente, não foi permitido. No entanto, todos os adolescentes pularam o portão da casa-abrigo e se dirigiram entusiasmados para o jovem. Os pedidos quase desesperados dos educadores para que aquela "festa" terminasse foram todos em vão. A solução encontrada foi acionar a polícia que, prontamente, veio até o abrigo e prendeu o 
jovem, que quase não ofereceu resistência. Para espanto geral dos funcionários que assistiam a cena, ele nem tentou fugir!

W. foi julgado e condenado a alguns anos de prisão por tráfico de drogas. Para os educadores e técnicos do abrigo, restou apenas o absurdo da situação. W. vivera longos anos no abrigos e sabia que o procedimento nessas situações era acionar o suporte da polícia. Ainda mais naquelas condições tão explícitas e desafiadoras, era nítido que em pouco instantes a polícia estaria chegando. E ainda, quando os policiais chegaram, sua reação quase passiva forneceu o sinal que faltava para se arriscar a conclusão de que W. se deixou prender, que, na verdade, ele "queria" ser preso. Tudo parecia um jogo de cartas marcadas: ele fez o que fez, pois sabia qual seria a reação do abrigo e parecia desejá-la para si.

A hipótese deste estudo para compreender esse aparente absurdo é que, quando W. se viu sem o abrigo, procurou inconscientemente outra instituição que pudesse ordenar a sua vida. Para ele, o mundo sem uma lei externa rígida era uma desordem insuportável com a qual ele não sabia lidar. O longo tempo de institucionalização vai gerando uma dependência cada vez mais intensa da própria institucionalização. Frente ao caos que é a vida de muitos desses meninos, uma lei dura, que ofereça limites e ordem, pode ser extremamente integradora dessas vidas despedaçadas. Tal explicação também oferece compreensão para a questão do ato infracional, muitas vezes impulsionado pela busca de uma instituição que ofereça contenção.

Por fim, não se quer com essa história fazer uma apologia da rigidez das leis. Ao contrário, tal situação deve servir como denúncia da falta de sentido na existência de muitos desses meninos e meninas a ponto de identificarem com leis autoritárias para conseguirem sobreviver.

\subsubsection{A participação de pessoas da comunidade no processo educativo}

Outro princípio de atendimento estabelecido pelo ECA (art. 92, inc. IX), a participação de pessoas da comunidade no processo educativo das crianças e adolescentes, ajuda na garantia ao direito à convivência comunitária, "facilitando o estabelecimento de novos vínculos e relações, bem como a oxigenação das práticas e rotinas institucionais" (IPEA, 2003, p. 14). 
O Levantamento Nacional propôs como critério de participação comunitária no abrigo possuir trabalho voluntário tanto na equipe técnica (assistentes sociais, coordenadores técnicos, nutricionistas, pedagogos e psicólogos) como na equipe de serviços complementares (estagiários, professores de reforço escolar, recreadores e terapeutas ocupacionais) (cf. IPEA, 2003, p. 14). A pesquisa tomou o cuidado de somente considerar a participação de voluntários nesses dois grupos de funcionários, pois existem outros, como a equipe de cuidados diretos, por exemplo, em que a presença de voluntários não é recomendada devido à própria característica de seu trabalho, que é geralmente mais inconstante.

Novamente, apenas 18,5\% (IPEA, 2003, p. 14) dos abrigos conseguiram atender a ambos os critérios colocados, indicando que são instituições ainda muito isoladas da comunidade de seu entorno.

Na questão da participação de pessoas da comunidade no processo educativo, a pesquisa em São Paulo constatou que as saídas em fins de semana, férias ou datas comemorativas, embora sejam permitidas pela quase totalidade dos abrigos (94\%), apenas $30 \%$ das instituições elas ocorrem com familiares, enquanto que saídas com voluntários, funcionários da instituição ou padrinhos somam 46\%, "o que pode significar uma tendência de maior facilitação de convivência e contato das crianças com a comunidade do que com as próprias famílias" (cf. AASPTJ-SP/NCA-PUCSP/SAS/FUNDAÇÃO ORSA, 2003, p. 127128).

Tal situação denota a importância dos vínculos comunitários na vida de crianças e adolescentes abrigados, sendo esses, muitas vezes, a referência mais próxima que estes meninos e meninas têm para pensar o que é uma família.

\section{$\underline{5.1 .4 \mathrm{O} \text { financiamento }}$}

A maior parte dos recursos $(58,5 \%)$ dos abrigos é privado (IPEA, 2003, p. 3), o que revela mais uma face da ausência histórica do Estado na questão da assistência à infância e à adolescência em situação de risco social, mesmo tendo esse segmento a absoluta prioridade estabelecida no art. 227 da Constituição Federal e no art. $4^{\circ}$ do ECA, que define em seu parágrafo único que a garantia de prioridade compreende, entre outras coisas, "destinação 
privilegiada de recursos públicos nas áreas relacionadas com a proteção à infância e à juventude".

As doações, tanto de pessoas físicas como de empresas, representam um percentual que não é desprezível: $8,9 \%$ e 5,2\%, respectivamente. Depender de doações, em qualquer porcentagem que seja, dá mostras das dificuldades cotidianas que os abrigos têm que enfrentar, uma vez que esse recurso não é contínuo, gerando instabilidade e dificuldades de planejamento, e nem sempre o que é arrecadado corresponde às necessidades da instituição em determinado momento. "Ademais, doações traduzem formas e costumes tradicionais de assistência e de caridade e não asseguram direitos" (AASPTJ-SP/NCAPUCSP/SAS/FUNDAÇÃO ORSA, 2003, p. 159). Enquanto o Estado não assumir suas responsabilidades em relação a esse tipo de atendimento, os abrigos continuarão à mercê da boa vontade das pessoas.

Apesar da dependência das doações girar em torno dos 15\%, chama a atenção o fato dessa porcentagem não ser maior, dado o grande apelo emocional que uma criança agrega às suas causas. De fato, a grande maioria das pessoas se comove facilmente quando sabe de alguma violência ou injustiça cometida contra crianças e adolescentes, especialmente contra crianças. Mas também é fato que a comoção e a indignação estão muito distantes da ação. Essa distância entre a comoção e a ação indica que, talvez, a criança que comove é diferente da maioria das crianças reais que batem às portas dos mais diversos projetos sociais pelo Brasil e pelo mundo. A sociedade se compadece com uma criança imaginária, vendida e maquiada pelas mídias, e não pela criança concreta que cheira, grita, discute, cobra, enfim, é viva.

Dentro dos recursos privados, destacam-se as receitas do próprio abrigo (24,9\%), principalmente aquelas que são provenientes da prestação de serviços (13,8\%) (IPEA, 2003, p. 3).

Diante desse quadro, é preciso desnaturalizar o fato histórico da grande incidência do financiamento privado em abrigos. Tal situação pode estar indicando que o Estado ainda não incorporou efetivamente a política de serviços de acolhimento institucional como uma política pública. Isso não necessariamente significa que uma política largamente baseada em convênios perca seu caráter público, mas, por exemplo, não costumamos ver uma Unidade Básica de Saúde (UBS) fazendo bazares, bingos e chás para complementar seus recursos.

Os recursos públicos são responsáveis por $41,5 \%$ do financiamento dos abrigos, sendo destes 18,1\% municipais, 15,9\% estaduais e 7,5\% federais (cf. IPEA, 2003, p. 3). Tal 
distribuição financeira está de acordo com a Lei Orgânica de Assistência Social (LOAS), que determina a municipalização como estratégia de execução da política de assistência, ficando sob a responsabilidade do Executivo Federal a definição de diretrizes e de políticas nacionais.

No entanto, na cidade de São Paulo, a situação ainda não se configura dessa maneira, pois $23 \%$ dos abrigos são conveniados com a SAS e $26 \%$ com a SEADS (cf. AASPTJSP/NCA-PUCSP/SAS/FUNDAÇÃO ORSA, 2003, p. 56), indicando que a municipalização ainda tem um grande caminho a percorrer para sua efetivação na metrópole paulista. Na época da pesquisa (2003), São Paulo encontrava-se em processo de transferência da responsabilidade do atendimento em abrigos do governo estadual para o municipal. Ainda é digno de nota que $49 \%$ deles não mantêm qualquer tipo de convênio com o poder público.

[...], entretanto, ainda não foram definidos os percentuais de participação da União, dos Estados e Municípios no financiamento dos direitos assistenciais; tampouco foram definidos os critérios de partilha dos recursos de origem federal para a contribuição do financiamento da totalidade dos serviços de prestação continuada previstos na LOAS, ficando o financiamento dos serviços assistenciais dependente em grande parte da participação voluntária da sociedade. (SILVA, 2003, p. 173)

A dependência do financiamento voluntário faz com que essas instituições fiquem extremamente vulneráveis, sujeitas às crises e às variações da economia, bem como da caridade e boa vontade alheias.

A participação da sociedade nas causas da infância sempre foi marcada pela falta de recursos financeiros regulares e contínuos e pelos recorrentes pedidos ao poder público para que desse prioridade a esta causa em relação a outros gastos. (SILVA, 2003, p. 182)

Tal situação favorece o ambiente de informalidade que ainda é muito característico da área social no Brasil. Assim, pode-se apontar a dependência do financiamento privado como um dos problemas essenciais do financiamento dos abrigos no Brasil.

Outro fato é que a dependência da verba privada faz com que os abrigos necessitem depreender um esforço para conquistá-las, com investimento de tempo e recursos humanos que, se tivessem seu financiamento garantido pelo Estado, poderiam se dedicar de modo mais qualificado à sua atividade-fim.

Um exemplo do que se está tratando pode ser encontrado na comparação entre abrigos governamentais e não-governamentais, uma vez que $95,88 \%$ dos primeiros são sustentados 
por verbas públicas, enquanto que apenas 32,2\% dos segundos dispõem desses recursos (cf. SILVA, 2003, p. 185). Essa diferença se expressa no custo médio/mês por abrigado, que gira em torno de $\mathrm{R} \$ 508,14$ nos abrigos públicos e $\mathrm{R} \$ 365,51$ nos privados (cf. SILVA, 2003, p. 189). Como hipótese desse custo mais elevado entre os serviços de acolhimento institucional governamentais a autora levanta os seguintes fatores, presentes nos equipamentos públicos: menor número de abrigados por unidade de atendimento, melhor remuneração salarial dos funcionários e menor incidência de trabalho voluntário (cf. SILVA, 2003, p. 189). Em outras palavras, pode-se supor que os abrigos governamentais são mais caros porque oferecem um atendimento melhor. No entanto, para a confirmação dessa hipótese, um levantamento qualitativo de diferentes programas de abrigo seria necessário, o que foge do foco deste trabalho, neste momento.

No que refere ao repasse federal para os abrigos da rede SAC, o valor é da ordem de $\mathrm{R} \$ 35,00$ per capita, sendo que o custo médio mensal por criança/adolescente abrigado é da ordem de R\$392,18 (cf. SILVA, 2003, p. 175). No entanto, ainda não existem estudos nem critérios técnicos bem estabelecidos que definam parâmetros para esses valores, de modo que

[...] não é possível avaliar se a participação do governo federal, em torno de $9 \%$, no financiamento dos abrigos conveniados é ou não adequada no que se refere ao pacto federativo da co-responsabilidade e do co-financiamento. (SILVA, 2003, p. 175)

Em outras palavras, se não existe um pacto regulamentado a respeito das parcelas que cabem a cada esfera de governo, pode-se concluir que o financiamento ainda é feito às escuras, sem que se saiba se o que se paga é suficiente ou não.

Além disso, como parte da política de assistência social e em consonância com o princípio da universalidade nela inerente, a Rede SAC/Abrigos deveria cobrir a necessidade de todas as crianças e adolescentes com demanda de abrigamento. Contudo,

[...] embora não existam estatísticas nacionais sobre o número total de abrigos para crianças e adolescentes no Brasil, as informações relativas à quantidade de abrigos existentes em alguns municípios brasileiros evidenciam que a rede $\mathrm{SAC}$ atende apenas uma reduzida fração das instituições que mantêm programas de abrigos para crianças e adolescentes no país. No município de São Paulo, por exemplo, o universo dos abrigos contemplados pela rede SAC é de apenas 17,5\%; em Porto Alegre, é de 
apenas 22\%; e no do Rio de Janeiro, de somente 15,8\%. (SILVA, 2003, p. 175-176)

Assim, a baixa amplitude da cobertura do financiamento federal é outro problema que pode ser apontado quando se analisa o financiamento dos abrigos.

O texto de Silva (2003, p. 178) ainda aponta para um desconhecimento geral dos dirigentes a respeito do financiamento público federal de suas entidades. Muitos não sabiam quando se iniciou o repasse, a origem dos recursos e mesmo se os repasses continuavam acontecendo ou não. Por outro lado, "pouco se conhece a respeito dos critérios que orientaram a conformação atual da rede SAC/Abrigos" (SILVA, 2003, p. 178), ou seja, quais foram as justificativas que contemplaram as instituições que atualmente recebem o recurso federal. Outros problemas encontrados foram: a falta de regularidade e pontualidade no recebimento dos recursos. Tal situação indica que se está diante de um significativo problema de gestão tanto nos abrigos como nos órgãos fomentadores.

Ainda, existem outras críticas importantes a serem consideradas quando se fala em financiamento dos abrigos. Silva e Mello (2003) apontam que a área da assistência social federal, com a ausência de estudos técnicos específicos, "concedeu ao atendimento de crianças e adolescentes em abrigos o mesmo tratamento dado às creches e aos asilos de idosos" (p. 28).

No campo do financiamento, isso significou que o método utilizado foi o repasse de verbas per capita, ou seja, as instituições recebem o recurso de acordo com o número de atendidos.

Assim, conquanto o financiamento per capita represente um avanço uma vez que agiliza e descentraliza o repasse de recursos - e uma maior eficiência, por utilizar uma menor quantidade de recursos humanos do que a modalidade de financiamento por projetos pode, por outro lado, desestimular as instituições a implementar ações que promovam a volta da criança e/ou adolescente ao convívio familiar e comunitário. (SILVA \& MELLO, 2003, p. 29)

Desse modo, a própria especificidade do serviço prestado deve ser levada em conta quando se trata de escolher qual o modelo de financiamento mais pertinente. Como se viu anteriormente, no caso dos serviços de abrigo, o repasse per capita não é recomendado, pois pode incentivar as instituições a não investirem no trabalho de reintegração familiar porque necessitam do dinheiro atrelado ao menino ou menina. Por exemplo: quando uma criança é 
desabrigada, toda a infraestrutura necessária para seu cuidado permanece na instituição (funcionários, mobiliário etc.) e precisa ser paga mesmo quando a criança não estiver mais lá, afinal o abrigo deve estar sempre preparado para a recepção imediata de um novo abrigado. Entretanto, se o financiamento estiver vinculado à criança, ou seja, se o repasse de recursos ocorrer pela modalidade "per capita", no período de vacância entre um desabrigamento e um novo abrigamento, a infraestrutura ficará sem pagamento.

Nesse sentido, o financiamento por projeto, apesar de mais trabalhoso, é o mais indicado quando se trata de serviços de acolhimento institucional. Nessa modalidade, o abrigo recebe as verbas atreladas ao projeto (ou aos projetos) que submete ao órgão financiador e não mais vinculadas ao número de crianças e adolescentes que atende. Nesse sistema, a instituição recebe determinada quantidade de recursos suficiente para financiar o abrigo como todo por período de tempo específico. Após esse período, as contas são auditadas e um novo pagamento é feito.

Obviamente que o número de crianças e adolescentes atendidos é um dado do projeto que deverá ser levado em consideração, mas não funciona mais como critério definidor da quantidade de recursos a serem transferidos. A "capacidade instalada" (recursos humanos, espaço físico, recursos materiais etc.), por exemplo, é outro elemento essencial a ser levado em consideração.

Por possuir o número de atendidos como principal elemento de repasse de verbas, o financiamento per capita não permite uma avaliação da qualidade dos serviços que estão sendo oferecidos e nem da adequação dos mesmos à nova legislação vigente, pois os dados normalmente presentes nos projetos das entidades, tais como seus objetivos, modelos pedagógicos e princípios de funcionamento não são devidamente analisados, correndo-se o risco do poder público financiar ações que desrespeitam as leis de proteção à criança e ao adolescente.

Assim, é importante fortalecer e expandir as modalidades de financiamento que priorizem o repasse de verbas públicas para os trabalhos de apoio, proteção e autonomia da família e não apenas da criança e adolescente separadamente. E somente no financiamento "por projeto" é possível fazer isso. O objetivo é incentivar a reorientação da vocação de instituições de abrigo que ainda apresentam programas que atendem os abrigados isolados de seu contexto. Para dar sustentabilidade às leis e aos marcos regulatórios vigentes (como a LOAS e a Política Nacional de Assistência Social - PNAS), que estabelecem a família como unidade de atuação das políticas de assistência social, é preciso que as verbas que financiam 
tais projetos também sejam direcionadas dessa maneira. Um princípio legal ou uma orientação técnica dificilmente se sustenta se não for acompanhada de verbas específicas para o incentivo de tais programas.

De maneira geral, a questão do financiamento parece ser um dos pontos mais atrasados no que se refere ao reordenamento institucional dos abrigos.

\section{$\underline{5.1 .5 \text { Os trabalhadores }}$}

A seguir, focar-se-ão os trabalhadores dos abrigos: quem são e como pensam esses profissionais.

\subsubsection{O papel de educador: um "profissional do vínculo"}

É importante perceber que a composição da equipe de cuidadores varia bastante ao longo da história dos abrigos e segue o modelo cultural regente em cada época.

Até o final do século XIX, a assistência à infância e à adolescência foi caracterizada pelo atendimento de tipo asilar, sendo de iniciativa das ordens religiosas e sociedades beneficentes. A ausência do Estado determinou que, até esse período, o cuidado à criança ou ao adolescente em situação de risco social fosse exercido predominantemente por agentes voluntários, tanto religiosos como leigos, sendo a remuneração uma prática quase inexistente (cf. CBIA/SP \& IEE/PUC-SP, 1993).

Tem-se, na realidade, a constituição de um complexo sistema de instituições religiosas para as quais "a formação religiosa era a intenção central do atendimento nessas entidades, sem maiores preocupações pedagógicas ou educacionais" (MELLO \& SILVA, 2003, p. 101). Era a alma da criança que interessava à Igreja e não tanto a criança em si. O interesse em jogo era muito mais o da Igreja do que o da própria criança ou adolescente.

Foi somente no início do século XX que a situação da infância e da adolescência pobre passou a preocupar outros profissionais, principalmente médicos e juristas. Apreensivos com a disseminação dos "males" da pobreza, bem como com a proliferação de doenças, esses 
novos profissionais passaram, baseados nos princípios higienistas da medicina social, a gerenciar os abrigos, sob o título de especialistas.

Deu-se início a um movimento classificatório das crianças e dos adolescentes, supostamente baseado em critérios científicos. No plano dos recursos humanos, tal processo de divisão e organização gerou um aumento e uma diversificação dos profissionais envolvidos no cuidado com os atendidos. Além dos médicos e advogados, psicólogos e professores, bem como outros profissionais especializados foram contratados e hierarquizados. Foram eles os responsáveis pelo crescente isolamento imposto às crianças e aos adolescentes abrigados, no processo de constituição das "instituições totais", já que todos os serviços por eles desempenhados eram executados dentro dos muros das entidades.

Em relação à postura dos profissionais, todos os níveis hierárquicos eram regidos por uma preocupação fundamental: o controle e a vigilância. Foi somente com as mudanças estimuladas pelo ECA, no sentido de que o acolhimento em abrigos deveria ser promotor de indivíduos cidadãos e autônomos, que os trabalhadores dessas instituições passaram a ter, finalmente, o papel de educadores.

É interessante perceber que, no decorrer da história, ao contrário do que possa parecer, somente muito recentemente a questão da criança e do adolescente abandonado foi incorporada ao campo da educação e da assistência social. Em seu início e até o final do século XIX, essa problemática pertenceu ao campo da religião e, posteriormente, no início do século XX, ao campo da segurança pública e da saúde.

Mesmo atualmente, ainda estamos longe da concepção de que os cuidadores são, na verdade, educadores, e que também todos os demais profissionais que desempenham suas funções específicas nos abrigos (psicólogos, assistentes sociais, cozinheiros, faxineiros, médicos, pedagogos, motoristas etc.) são educadores também, uma vez que todas as atividades possuem (ou devem possuir) um aspecto educativo. Dentro do abrigo, educador é todo adulto em relação com as crianças e adolescentes. Essa função pedagógica não é algo dado naturalmente. Ao contrário, é fruto de conquistas históricas dos movimentos sociais de defesa e garantia dos direitos das crianças e dos adolescentes.

Sendo assim, torna-se importante que todo o quadro de pessoal esteja afinado com a proposta contida no projeto educativo do abrigo. Caso contrário, poderá haver um descompasso na forma de conduzir o processo socioeducativo. (AASPTJ-SP/NCA-PUCSP/SAS/FUNDAÇÃO OSRSA, 2003, p. 131) 
No entanto, tais apontamentos levam a indicar o desconhecimento acerca do trabalho educativo específico dos abrigos: a educação informal. Muitos professores e pedagogos (principalmente os professores) normalmente são formados para atuar em contextos formais de ensino, tais como a sala de aula. No entanto, a especificidade do trabalho educativo em abrigos leva-os a ter que atuar em contextos absolutamente informais: nas refeições, na hora do banho, na hora de dormir etc. O grande desafio da educação informal é justamente encontrar nas atividades mais cotidianas e corriqueiras espaços para a atuação pedagógica e mesmo psicológica. É encontrar na maneira de vestir de um determinado jovem assunto sobre sua necessidade de pertencimento a um grupo. Ou ainda alguma observação feita na hora do banho ser uma oportunidade para uma conversa posterior com a criança sobre a questão do cuidado com o próprio corpo. Atualmente, já existe um profissional específico para esse trabalho de educação informal: o educador social. A figura desse trabalhador, suas funções e competências são uma das elaborações mais atuais no campo dos recursos humanos para abrigos.

Para o trabalho do educador e, na realidade, para todo o trabalho educativo em abrigos, o crucial é conseguir superar a dicotomia entre atividades cotidianas e atividades pedagógicas ou atividades operacionais e atividades técnicas. A essência do trabalho educativo em abrigos está, justamente, em atuar na tensão dessa dicotomia, encontrando o pedagógico no cotidiano, o técnico no operacional.

Certa vez, enquanto trabalhava como educador, recebi uma criança de cerca de 6 anos de idade, vítima de violência física. Seu pai costumava agredi-lo com pedaços de pau, o que já havia deixado inúmeras cicatrizes em seu corpo. O menino chegou ao abrigo tarde da noite. Todos já estavam dormindo. Ele estava muito assustado, sujo e com fome, pois havia fugido de casa. Encaminhei então o menino ao banho. Depois que ele saiu, já um pouco mais calmo, fui até a rouparia do abrigo para vesti-lo com roupas novas, evitando que colocasse as antigas. Nesses momentos, é importante perceber que o banho, além da limpeza física que ele propicia, também opera uma sensação de alívio em relação às situações difíceis vividas anteriormente. Funciona como se, junto com a água do banho, fosse embora também um pouco do sofrimento associado com a sujeira do corpo.

Nesse sentido, a troca de roupas também carrega um importante peso simbólico. É importante fornecer roupas novas, uma vez que as antigas estão "impregnadas" dos acontecimentos que se deseja momentaneamente esquecer. No entanto, não se deve jogar fora 
as roupas antigas, afinal, elas carregam uma parte da história do sujeito que, boa ou ruim, é constitutiva daquela pessoa. Pensando nessas questões, falei para o menino que ele poderia escolher qualquer roupa que quisesse, mas que guardaríamos as antigas. Ele escolheu uma bermuda e, logo em seguida, uma camiseta que continha um desenho do homem-aranha estampado nela. Percebi que ele ficou muito feliz com a escolha e nos dirigimos à cozinha conversando sobre o super-herói, que acabei descobrindo ser o seu preferido. Servi um prato de comida à criança e, apesar de já ter jantado, coloquei um pequeno prato também para mim.

Nesses momentos de dor, a sensação de se compartilhar algo, por mais insignificante que possa parecer, é muito acolhedora. Começamos a conversar enquanto comíamos e o menino $\operatorname{logo}$ começou a falar, mesmo sem eu ter perguntado, a respeito das surras e espancamentos aos quais seu pai o submetia. Ouvi com atenção. O menino precisava falar, mas isso o estava deixando cada vez mais triste. Em um determinado trecho do relato, disse que as agressões que tinham acontecido naquela mesma noite foram especialmente violentas, pois seu pai havia bebido. Falou, cabisbaixo, que recebeu uma paulada tão forte que o pau chegou a quebrar em suas costas. Então respondi: "Para o pau ter quebrado nas suas costas, você deve ser tão forte quanto o homem-aranha". O rosto do garoto se iluminou. Ele olhou para sua camiseta e a tristeza momentaneamente passou. Voltou a falar das agressões, mas agora de um lugar totalmente diferente, comentando as violências sofridas sempre em comparação com alguma atitude ou característica do homem-aranha.

Pensei que, com minha intervenção, a partir de algo absolutamente cotidiano, como a escolha de uma roupa para vestir, consegui criar na criança uma identificação com seu herói preferido, o que a auxiliou a encontrar forças para superar aquele momento tão difícil de sua vida. No meio daquele mar de sofrimento, a inclusão do elemento lúdico parece-me que foi muito saudável para aquele menino. Além disso, os cuidados que tomei em relação às roupas novas e antigas, e o compartilhar da refeição também são ilustrações do que foi apontado anteriormente a respeito da necessidade do educador saber trabalhar na tensão entre atividades técnicas e atividades operacionais.

Esse exemplo baseou-se em posturas que se tomam no caso de um acolhimento realizado. No entanto, a tarefa do educador vai muito além desse momento inicial. Principalmente em relação às crianças e aos adolescentes que permanecem no abrigo por mais tempo, sua função é, basicamente, ser um "adulto com o qual [as crianças e adolescentes abrigados] possam estabelecer uma relação afetiva estável, até que a integração ao convívio familiar seja viabilizada novamente" (PNCFC, 2006, p. 31), visto ser a instabilidade e a 
inconstância dos vínculos com o mundo adulto o que normalmente caracteriza a história de vida desses meninos e meninas, conforme descreve-se melhor quando abordarmos, posteriormente, no texto, algumas características psicológicas das crianças e adolescentes abrigados.

O combate à desconfiança que as crianças e os adolescentes em situação de vulnerabilidade aprendem a desenvolver em relação àqueles que supostamente deveriam ter cuidado delas, deve ser feito oferecendo o oposto do que eles estão acostumados: alguma estabilidade nas relações afetivas, o que nem sempre é fácil por conta do processo de "teste de vínculo" que também será descrito no trecho mencionado acima. É esse trabalho de vincularse com aqueles que normalmente encontram-se avessos ao vínculo que faz desse trabalhador um especialista nesse assunto e que se pode denominar de "profissional de vínculo".

Ainda, gostaria de tratar do educador sob outro prisma. Especialmente para crianças e adolescentes que passam muito tempo em abrigos, uma função importante é a de guardião de histórias de vida. O educador deve ser aquela pessoa que se dirige ao abrigado e diz: "Você se lembra que quando você era pequeno, você...”. A criança ou adolescente abrigado deve sentir que sua história foi importante para alguém, que alguém continuará a se lembrar dele, mesmo depois que sair do abrigo.

\subsubsection{O perfil dos profissionais}

Em relação ao perfil atual dos profissionais que trabalham em abrigos, Mello \& Silva (2003, p. 105) apresentam uma pesquisa com os dirigentes dessas instituições, a qual mostra que $60,4 \%$ deles são mulheres. Na realidade, em todos os abrigos nos quais este pesquisador trabalhou ou com os quais manteve contato, não só a coordenação era majoritariamente exercida por mulheres, mas toda a equipe funcional era composta por uma maioria feminina.

É interessante perceber que tal situação acaba por reproduzir, dentro da instituição, aquela que é, talvez, a principal característica das famílias de crianças e adolescentes em situação de vulnerabilidade social: a ausência da figura masculina.

A maioria feminina entre os trabalhadores dos abrigos ainda aponta para um preconceito bastante arraigado em nossa sociedade: o de que o cuidado com crianças e adolescentes é um trabalho naturalmente feminino. 
Outro dado importante levantado pela pesquisa com os dirigentes de abrigos é que a maioria deles (60,8\%) possui ensino superior completo (cf. MELLO \& SILVA, 2003, p. 107). Tal panorama não deixa de surpreender quando se compara esse resultado com os baixos índices encontrados pelo Levantamento Nacional. Obviamente, sabe-se do processo de sucateamento que o ensino superior vem sofrendo no Brasil, de modo que a alta qualificação desses profissionais não garante por si só a qualidade dos serviços por eles oferecidos. Entretanto, essa reflexão pode seguir outro caminho e levantar a hipótese de que, se hoje a maioria dos abrigos ao menos possui dirigentes supostamente capacitados para desempenhar o serviço, o que lhes faltam são condições de trabalho. Em outras palavras, falta uma política pública que realmente crie as possibilidades de realizar seu trabalho (recursos, rede de apoio em saúde, programas de capacitação continuada etc.).

Tal hipótese ganha força quando se apresenta um dado retirado da fala dos próprios profissionais dos abrigos da cidade de São Paulo, apontando que

[...] a falta de profissionais foi a maior dificuldade sinalizada (98 abrigos), seguida do trabalho com as famílias (87 abrigos), da obtenção de convênios (84 abrigos), de lidar com a sexualidade das crianças e dos adolescentes (39 abrigos) e de obter registro junto ao CMDCA (32 abrigos). (AASPTJSP/NCA-PUCSP/SAS/FUNDAÇÃO ORSA, 2003, p. 153)

Das cinco maiores dificuldades apontadas pelos próprios abrigos, três delas se referem diretamente à política pública, uma em relação à metodologia de trabalho com as famílias e apenas uma se refere às dificuldades com os próprios abrigados, de modo que fica claro, para os próprios trabalhadores dessas instituições, que questões relativas às próprias crianças e aos adolescentes não se configuram como os maiores de seus problemas. Ao contrário, são questões de ordem estrutural, como falta de funcionários e falta de convênios, que parecem atrapalhar mais.

$\mathrm{Na}$ realidade, supõe-se que a persistência de dificuldades de ordem tão elementar como falta de funcionários, falta de recursos financeiros ou ainda, por exemplo, a superlotação inviabilizam de tal modo a qualidade do serviço prestado que as questões relativas à própria demanda (sexualidade, agressividade, medos, angústias etc.) são, sem que se perceba, colocadas em segundo plano. Em uma instituição sem as condições mínimas de trabalho, as próprias crianças e adolescentes são invisibilizados. Não se chega a realmente prestar atenção neles, pois os problemas de ordem infraestrutural são os que saltam aos olhos. 
No entanto, é preciso tomar cuidado com as insistentes falas sobre a falta de funcionários, pois elas podem esconder outras questões. Por exemplo, longe de ser um discurso reivindicativo legítimo pela melhoria das condições de trabalho, a "falta de profissionais" pode facilmente assumir a forma de um discurso queixoso e de desresponsabilização, ou seja, uma forma de atribuir ao outro uma responsabilidade que é sua. Nesse sentido, torna-se uma forma reativa de se lidar com as dificuldades do trabalho: "se eu não dou conta é porque se precisa de mais funcionários".

Felizmente, hoje, possuímos um instrumento para avaliar de modo mais objetivo essas questões, que é a NOB-RH/SUAS (2006). Estabelecendo o número de funcionários mínimo por abrigo, ${ }^{23}$ a NOB permite ponderar um pouco mais objetivamente se efetivamente faltam funcionários em um determinado abrigo ou se falta capacitação e supervisão para aqueles que lá estão.

A NOB-RH traz em sua aprovação uma grande mudança na maneira de gerir os recursos humanos na área da assistência social. Nessa questão da quantidade de funcionários, por exemplo, deixa-se para trás o tempo em que o único parâmetro era a cabeça do gestor, quem quer que ele seja. Atualmente, essa discussão passa a ser balizada por uma política pública. Se se considera que um determinado número de profissionais por abrigado é muito ou é pouco, essa é uma discussão de política pública e é nesse âmbito que deve reivindicada. ${ }^{24}$

Já o trabalho com as famílias e a sexualidade são, sob o ponto de vista deste estudo, simplesmente aquelas questões relativas à demanda que conseguiram furar a imensa nuvem de obstáculos mais básicos que insistem no primeiro plano. Isso, talvez, porque representem, de fato, os grandes vazios metodológicos do trabalho em abrigos: esses profissionais apresentam dificuldades para desenvolver um trabalho psicossocial de qualidade com essas famílias, e também apresentam dúvidas sobre o que fazer quando a sexualidade eclode dentro do abrigo.

Existe ainda outra informação que chama a atenção quando comparada com o grau de escolarização encontrado entre os dirigentes de abrigos e que pode ser considerada como exemplo da formação deficitária desses profissionais: apenas 48,8\% deles se consideram bem informados a respeito do ECA (cf. SILVA, 2003, p. 197), lembrando que esse é o principal marco legal que regula a atividade dessas instituições, bem como de toda a área de proteção à

\footnotetext{
${ }^{23}$ A adequação da proposta da NOB-RH será discutida no item dedicado à aparência residencial do abrigo.

${ }^{24}$ Fica nítido que os Conselhos de Assistência Social e de Direitos da Criança e do Adolescente têm a sua responsabilidade aumentada na medida em que esse processo de parametrização em políticas públicas vai avançando, uma vez que são essas as instâncias responsáveis por sua deliberação e acompanhamento.
} 
infância e à adolescência. Ainda que 89,8\% deles disseram ter conhecimento do artigo 92 (cf. SILVA, 2003, p. 197), que trata dos princípios que uma entidade de abrigo deve seguir, tal situação não é tranquilizadora, pois não se pode depreender que o conhecimento de um único artigo isolado, ainda que seja o mais importante para o trabalho nos abrigos, seja suficiente para que tais profissionais tenham verdadeiramente compreendido a radicalidade proposta nos princípios do ECA e, muito menos, sua prática concreta, o que seria o ideal. Mais uma vez encontramos diante da constatação de que a lei, no caso o ECA, ainda se encontra muito distante de seu cumprimento na realidade.

Entre os dirigentes, a profissão mais encontrada foi a de assistente social $(10,7 \%)$ seguida de perto por professores $(10,5 \%)$ e pedagogos $(10,2 \%)$. Depois deles aparecem os religiosos (7,5\%), os advogados (4,9\%) e somente depois os psicólogos (3,7\%) (cf. MELLO \& SILVA, 2003, p. 110).

Como psicólogo de formação, a primeira consideração que me salta aos olhos é a baixa presença dessa profissão entre os dirigentes de abrigos, indicando, talvez, um distanciamento ainda existente entre a psicologia e as entidades de abrigo, pelo menos no que se refere à sua gestão.

Em relação à remuneração, é bastante expressivo o número de 59,3\% dos dirigentes que afirmaram não receber qualquer tipo de salário, ou seja, a maior parte dos abrigos é coordenada por voluntários. Frente a essa situação, poder-se-ia pensar que essas pessoas se dedicam apenas parcialmente ao trabalho nos abrigos. No entanto, uma análise do tempo dedicado a esse serviço mostrou que $51,4 \%$ dos dirigentes trabalham 40 horas ou mais por semana no abrigo, o que significa dedicar o dia inteiro ao programa (cf. MELLO \& SILVA, 2003, p. 111).

Algumas hipóteses a respeito desses dados são importantes. Embora não se tenha comprovação empírica, o elevado índice de voluntariado convida a pensar no modo de vida dessas pessoas que se dedicam integralmente a uma atividade pela qual poderiam ser remuneradas, mas não o são. Tal situação sugere um modelo abnegado de vida, quase um ascetismo. Considera-se aqui a existência de um preconceito cultural, incorporado inconscientemente por esses indivíduos, de que trabalhar por uma "causa nobre" por si só já prescinde de qualquer remuneração. A possibilidade de realizar tal trabalho já é a própria remuneração. É, na verdade, uma reatualização do modelo religioso que regia o atendimento em abrigos até o final do século XIX. Se o domínio da Igreja Católica tem declinado desde o 
início do século XX, sua influência espiritual na vida dos trabalhadores dessas instituições ainda está muito longe de ser superada.

Uma das principais influências negativas dessa "herança espiritual" é o atraso do que se pode chamar de profissionalização do setor. Por esse movimento de profissionalização entende-se, por exemplo, o sugerido pelo PNCFC em relação ao estabelecimento de indicadores qualitativos e quantitativos de avaliação dos programas, o reconhecimento da ocupação de educador social nos programas de proteção, a qualificação continuada dos profissionais etc. Tal movimento é absolutamente atual e está acontecendo não só com os abrigos, mas com todo o campo do trabalho social. As históricas justificativas baseadas no ideário da caridade, fruto da enorme influência, visível até hoje, da Igreja Católica nas ações desenvolvidas com os excluídos, devem ser paulatinamente substituídas por um olhar político sobre a questão da desigualdade social. Não se luta mais por amor ao próximo, mas por justiça social.

Nesse sentido, a remuneração é uma característica essencial para que esses trabalhadores possam conceber sua ocupação como uma atividade profissional qualquer (com suas peculiaridades, obviamente) e não como uma obra de caridade. Um exemplo do que se quer dizer é um dado do Levantamento Nacional, o qual mostra que $18 \%$ dos dirigentes de abrigos declararam que assumiram este cargo em função de demandas de amigos (cf. BEGHIN \& PELIANO, 2003, p. 276).

Provavelmente esses sejam os dirigentes que moram no local de trabalho, o
que explicaria essa dedicação permanente. [A pesquisa revelou] que os
profissionais da religião ( $37 \%$ ) e os profissionais do ensino $(26,1 \%)$ somam
mais da metade desses dirigentes, sendo que os que se declararam
"religiosos" representam um terço dos que se dedicam integralmente ao
abrigo (32,\%). (MELLO \& SILVA, 2003, p. 112)

Um trabalho concebido como uma obra de caridade voluntária pode ser compreendido como parte do projeto religioso individual desses sujeitos, o que coloca certos conflitos com a nova concepção da assistência à infância e à juventude, baseada não mais na ideia de caridade, mas sim na de crianças e adolescentes como sujeitos de direitos.

Além disso, morar no local de trabalho levanta outros complicadores. Pode-se pensar que, para essas pessoas, não há vida fora do trabalho. A grande maioria de seus relacionamentos acontece dentro da instituição, assim como boa parte de seus afetos estão 
nela investidos. A consequência é que a instituição se torna "total" também para seus trabalhadores. $^{25}$

Entre aqueles que afirmaram receber alguma remuneração, a média salarial apontada foi de $\mathrm{R} \$ 1.103,96$, sendo que a faixa de maior concentração de dirigentes era a dos que recebiam entre R\$ 500,00 e R\$ 999,00 (cf. MELLO \& SILVA, 2003, p. 113), remuneração que pode ser considerada baixa para a responsabilidade que incide sobre esse profissional, lembrando que o ECA o equipara ao guardião legal das crianças e adolescentes abrigados, para todos os efeitos de direito (art. 92, parágrafo único).

\begin{abstract}
Ainda que algumas regiões apresentem remuneração média maior, de maneira geral pode-se dizer que não são os ganhos monetários que movem os dirigentes dessas entidades a exercer essa função, visto que a maioria não é remunerada e, entre os que são, os salários não são muito competitivos, considerando-se a escolaridade e a formação da maioria. (MELLO \& SILVA, 2003, p. 115)
\end{abstract}

As autoras ainda apontam que a maior motivação desses profissionais para trabalhar nos abrigos foi, em primeiro lugar, a humanitária (44,3\%), em segundo lugar, a religiosa $(29,0 \%)$ e somente depois, a profissional (23,1\%) (MELLO \& SILVA, 2003, p. 115). Nota-se que se está diante de uma ocupação realmente muito peculiar, para a qual a motivação profissional, que se espera encontrar em primeiro lugar para a maioria das demais profissões, fica apenas na terceira posição no caso dos dirigentes de abrigos. Percebe-se, mais uma vez, que a ética desses trabalhadores está muito associada a uma ideia de abnegação, como se a remuneração manchasse a "nobreza" do trabalho social.

A partir desse quadro é bastante coerente o dado de que $42,1 \%$ desses dirigentes já participaram ou participam de conselhos de direitos da criança e do adolescente, instituições que discutem, deliberam e controlam as políticas públicas voltadas para a área (cf. MELLO \& SILVA, 2003, p. 118). Em outras palavras, são pessoas politizadas. Mas, de acordo com o panorama que se construiu desses profissionais, não se pode deixar de apontar que a política também pode funcionar como uma forma de ascetismo. Além disso, não podemos nos furtar de marcar que

\footnotetext{
${ }^{25}$ Vale lembrar que o objetivo deste estudo não é estabelecer uma hierarquia dos trabalhadores laicos em relação àqueles que têm vinculação religiosa. Trata-se apenas de tentar entender suas motivações e os possíveis impactos que elas podem ter no atendimento às crianças e aos adolescentes.
} 
[...] a participação dessas pessoas nesses espaços é importante não só para a busca da maior adequação das políticas às reais necessidades de crianças e adolescentes em situação de abrigo, para inspirar e orientar as práticas das próprias instituições que executam a medida de proteção, dadas as mudanças tão profundas que decorrem das inovações legais e pelas mudanças conceituais que o Brasil viveu nos últimos 15 anos com relação à forma de ver e cuidar de suas crianças e seus adolescentes. (MELLO \& SILVA, 2003, p. 118)

No que se refere aos demais funcionários de um abrigo, eles são normalmente divididos de acordo com a proposta de Mello \& Silva (2003, p. 115): uma equipe técnica multidisciplinar formada por assistentes sociais, psicólogos, nutricionistas, pedagogos e outros profissionais relacionados, responsável pela concepção e condução do programa, bem como pelo projeto educativo do abrigo e atendimento individualizado às crianças e aos adolescentes abrigados e seus familiares; uma equipe de cuidados diretos; e uma equipe de apoio operacional, que desempenha as tarefas de limpeza, preparo das refeições etc.

Salienta-se que o quadro descrito pode ser considerado um modelo ideal, especialmente em relação à quantidade e à diversidade de profissionais com nível superior. Em uma cidade como São Paulo, profícua de centros universitários, a pesquisa da AASPTJSP/NCA-PUCSP/SAS/Fundação Orsa (2003) verificou que "em metade dos abrigos pesquisados não existem assistentes sociais, psicólogos ou pedagogos” (p. 129). Tal situação é extremamente grave, pois como são esses os profissionais que costumam ser responsáveis pela maior parte do trabalho de desabrigamento, pode-se inferir que a reintegração familiar, tarefa essencial dos abrigos, fique altamente fragilizada nessas instituições. Alguns desses abrigos justificaram que "não têm assistentes sociais nem psicólogos em seus quadros fixos, porque a prestação de seus serviços é voluntária" (AASPTJ-SP/NCAPUCSP/SAS/FUNDAÇÃO ORSA, 2003, p. 129), situação que ameniza este estado, mas não deixa de ser preocupante porque continua a comprometer a continuidade e a estabilidade do serviço de retorno à convivência familiar.

Diante da situação geral de escassez de profissionais de nível superior nos quadros de recursos humanos dos abrigos, atualmente, está colocada uma discussão importante, mas que pode parecer utópica: é a questão da necessidade ou não de técnicos para desempenhar o trabalho de cuidados diretos.

$\mathrm{Na}$ realidade, tal discussão se coloca na contramão de uma tendência de desvalorização do trabalho de cuidados diretos, já que "embora 58\% das respostas tivessem apontado para o ensino médio, o grau de escolaridade exigida para a função não é 
padronizado". Não se padroniza porque não se considera tal função merecedora de profissionais com um nível mais elevado de qualificação. Os efeitos desse processo de desvalorização, no entanto, aparecem até mesmo na fala dos próprios trabalhadores, quando "alguns entrevistados sinalizam como condição o saber ler e escrever" (AASPTJ-SP/NCAPUCSP/SAS/FUNDAÇÃO ORSA, 2003, p. 132). Obviamente, não se trata de defender que educar é um trabalho para especialistas. No entanto, deve-se reconhecer que também não é um trabalho para qualquer um, especialmente quando se trata da educação de crianças e adolescentes com histórias de vida tão sofridas e necessidades tão complexas.

Assim, essa equipe costuma ser composta por profissionais de qualificação mais baixa, responsáveis mais pela execução de um determinado projeto educativo do que pela sua elaboração, ainda que conjunta com os profissionais de nível superior. Vê-se, assim, reproduzida dentro dessas instituições, uma separação bastante característica do modo moderno e capitalista de organização do trabalho, que é a separação entre trabalho intelectual e trabalho braçal. Esta aparece como sintoma, no caso específico que se está analisando, de uma desqualificação da tarefa de cuidados diretos de crianças e adolescentes.

Obviamente, não se está defendendo que toda a equipe de cuidados diretos passe a ser composta por técnicos. No entanto, existem outros modelos de organização das funções que podem ajudar a problematizar a distribuição das tarefas no interior dos abrigos. Nos abrigos em que trabalhei, por exemplo, existe a figura de um técnico (que pode ter a formação tanto de psicólogo como de assistente social ou pedagogo) que é responsável por coordenar a equipe de cuidados diretos, no entanto, ele próprio também executa as tarefas que é encarregado de coordenar. Tal figura é justamente a do educador social que foi mencionada anteriormente. O convívio cotidiano com as crianças e com os adolescentes lhe proporciona as oportunidades para exercer seu trabalho de educação informal, bem como lhe confere legitimidade para supervisionar a equipe de cuidados diretos, já que também ele vivencia na pele as dificuldades e o desgaste dessa ocupação.

Outra vantagem que a figura do educador social tende a provocar dentro da dinâmica das funções de um abrigo é uma maior aproximação entre a equipe técnica e a equipe de cuidados diretos, visto que é extremamente frequente o distanciamento entre esses dois grupos de profissionais. Esse distanciamento se traduz concretamente em incompreensões mútuas, exigências descabidas e falta de legitimidade daqueles que deveriam coordenar as ações do abrigo. Nesses casos, o educador social pode funcionar como uma verdadeira ponte entre o 
técnico, já que ele também é um profissional de nível superior, e a equipe de cuidados diretos, já que ele também atua cotidianamente com as crianças e os adolescentes.

Tal proposta acarretaria um impacto financeiro que, muitas vezes, não é desprezível para instituições, especialmente para as de pequeno porte, já que incorporam mais profissionais qualificados em sua folha de pagamento. No entanto, muitos abrigos têm desenvolvido estratégias para melhor gerir os gastos com recursos humanos sem fugir da adequação às diretrizes do reordenamento institucional proposto pelo ECA. É o caso, por exemplo, de uma única equipe técnica responsável pelo atendimento a mais de uma unidade de abrigo, cada uma com um número reduzido de crianças e adolescentes (cf. MELLO \& SILVA, 2003, p. 121).

Outro ponto importante de ser destacado quando se reflete sobre os recursos humanos de um abrigo é um grupo adicional aos três já descritos, que diz respeito à administração da instituição. A quantidade e a diversidade dessa equipe é bastante variável, de acordo com o tamanho da instituição. Pode se constituir de secretárias, office boys, telefonistas, almoxarifes, captadores de recursos etc.

Certamente, essas são funções importantes à natureza institucional de uma entidade de abrigo. Vale observar, entretanto, sua participação no total de funcionários da instituição - que se espera não ser muito grande - bem como a necessidade de sua permanência no mesmo ambiente de moradia das crianças e dos adolescentes. É perfeitamente possível, por exemplo, a manutenção de um escritório institucional separado das unidades residenciais de moradia-abrigo, o que preservaria o ambiente residencial que se deseja para uma instituição de abrigo. (MELLO \& SILVA, 2003, p. 122)

O ambiente de trabalho, ou seja, o espaço físico no qual as atividades se desenvolvem é extremamente relevante para a manutenção de uma dinâmica residencial. Além do exemplo já exposto, o caso do grupo de serviços especializados (médicos, dentistas, fonoaudiólogos, instrutores de profissionalização, professores de ensino regular etc.) também merece destaque. É comum que os abrigos acabem construindo uma rede de profissionais voluntários para esses atendimentos, dada a sua escassez ou dificuldade de acesso na rede pública. No entanto, é preciso cuidado no sentido de se evitar que tais serviços sejam prestados no interior dos abrigos.

Nesse ponto, vale considerar que a herança cultural das instituições totais muitas vezes pauta a avaliação de que o trabalho de uma entidade é tanto 
melhor quanto maior o número de profissionais e serviços disponíveis para a atenção aos abrigados. Além disso, por vezes ainda perdura a idéia de que é mais "prático" e "econômico" atender as crianças e adolescentes em conjunto, dentro do próprio abrigo, do que se buscar os serviços externos em atendimento às especificidades e às necessidades individuais. (MELLO \& SILVA, 2003, p. 123)

No entanto, a divisão sugerida entre equipe técnica, administrativa, de cuidados diretos e de apoio operacional é meramente ideal. Por exemplo, "ressalta-se que observações indicaram ainda a existência de assistentes sociais que acumulam funções administrativas. Há também educadores que acumulam suas funções com as de ajudante de cozinha" (AASPTJSP/NCA-PUCSP/SAS/FUNDAÇÃO ORSA, 2003, p. 130). Assim, parece que a indefinição de papéis é uma constante em muitos abrigos.

Em relação a isso, por exemplo,

[...] as funções do educador, dos funcionários que assumem funções relacionadas à rotina diária dos abrigos e, até mesmo, a dos profissionais de nível superior, não estão ainda esclarecidas para alguns dos entrevistados. Há necessidade de definição quando às atribuições do corpo de funcionários, a fim de que a atuação seja mais profissionalizada. (AASPTJ-SP/NCAPUCSP/SAS/FUNDAÇÃO ORSA, 2003, p. 134)

Tem-se claro que o ambiente de trabalho desenvolve-se em uma tensão entre a formalidade (inerente a qualquer local de trabalho) e a informalidade (algo específico dos abrigos, afinal, trabalha-se dentro de uma casa). Por um lado, isso pode ser bastante positivo na medida em que se torna possível propiciar aos atendidos um ambiente que se aproxima de uma dinâmica residencial. Uma postura mais informal dos funcionários tende a ser benéfico na rotina das crianças e dos adolescentes abrigados.

No entanto, para o desenvolvimento e a gestão do trabalho, essa mesma postura pode incentivar uma atitude não profissional. É preciso que os funcionários dos serviços de acolhimento entendam que a informalidade é a maneira específica de se trabalhar de modo profissional em abrigos. Não se trata de impor a essas instituições uma lógica de funcionamento e eficiência empresarial. No entanto, sem um olhar estratégico a essa informalidade, ela pode ser tendencialmente geradora de conflitos entre o que deveria ser da ordem pessoal do trabalhador e o que se relaciona à ordem profissional. Pode incentivar que os profissionais se acomodem. Como essência desse "olhar estratégico" deve estar a 
consciência de que a informalidade não só é intencional, mas também uma postura pedagógica.

Outra característica importante para que se tenha uma visão geral dos recursos humanos em atividade nos abrigos é o alto índice de voluntários em seus quadros: $25,3 \%$ dos trabalhadores dessas instituições (MELLO \& SILVA, 2003, p. 124). Apesar de estarem presentes tanto nas equipes técnicas como nas de cuidados diretos, felizmente a maior parte deles se concentra nas tarefas que se pode chamar de adicionais, tais como os serviços especializados (médicos, dentistas, fonoaudiólogos, advogados etc.) ou ainda os serviços complementares (cabeleireiros, professores de dança, música, teatro, esportes, orientadores espirituais etc.). Isso porque o trabalho voluntário tem, predominantemente, a característica de ser muito instável. Como não existe vínculo empregatício, esse não é um profissional com o qual se pode contar. Sendo assim, seria absolutamente desaconselhável a presença de voluntários entre a equipe de cuidados diretos, por exemplo, sobre a qual recaem os vínculos mais fortes das crianças e dos adolescentes, de modo que é extremamente importante que essa equipe seja a mais estável possível.

Em abrigos, a entrada e a saída de profissionais é algo muito mais complexo e conflituoso do que em outros ambientes de trabalho, pois envolve a construção ou o rompimento de relações afetivas com os atendidos. A alta rotatividade dos profissionais está inversamente relacionada à capacidade dos atendidos de manterem vínculos estáveis com a equipe do serviço. A saída de um funcionário, se não for bem trabalhada, pode, por exemplo, ser vivida pelas crianças como uma nova experiência de abandono. Nesse sentido, a peculiar inconstância, característica do trabalho voluntário, pode gerar nas crianças e nos adolescentes a sensação do que se tem chamado de reatualização do abandono.

É preocupante que $84,6 \%$ dos serviços de advocacia, 52,4\% dos serviços especializados e 51,3\% da administração institucional dos abrigos sejam exercidos por voluntários (cf. BEGHIN \& PELIANO, 2003, p. 266). É, inclusive, nessa discussão que aparece outro dado preocupante, mas bastante elucidativo da relação da psicologia com o trabalho desenvolvido nessas instituições: $39,6 \%$ delas disseram que sua atividade de assistência psicológica depende exclusivamente de trabalho voluntário (cf. MELLO \& SILVA, 2003, p. 127). Isso indica que a aproximação dos psicólogos com esse campo de trabalho ainda é bastante informal.

Sendo assim, 
[...] o que se observa, de maneira geral, é que, diferentemente do que legisla o estatuto, o trabalho voluntário não é uma atividade apenas complementar ao programa de abrigo: ele cumpre funções essenciais, tais como a relação com o poder Judiciário e o Ministério Público, o cuidado com a saúde das crianças e dos adolescentes e uma parte não negligenciável do acompanhamento diuturno dos abrigados. (BEGHIN \& PELIANO, 2003, p. 268)

A questão do trabalho voluntário em serviços públicos abre um importante debate a respeito da relação público/privado. Por um lado, existe o argumento de que tal participação fortalece a política pública, na medida em que incentiva a intervenção conjunta entre Estado e sociedade civil. De outro, pode-se pensar que a participação na forma de voluntariado favorece um processo de "Estado mínimo", que se aproveita do trabalho da sociedade civil para esquivar-se de suas responsabilidades.

Beghin e Peliano (2003) descrevem essa contradição da seguinte maneira:

[...] de um lado, o entendimento de que o serviço voluntário se insere em um modelo de gestão da pobreza, associado a práticas clientelistas ou de assistencialismo paliativo, distintas da lógica dos direitos sociais; e, de forma contrária, a defesa de que o voluntariado pode ser protagonista de transformações sociais na medida em que contribui para a construção de uma nova cidadania baseada em valores como o da solidariedade. (BEGHIN \& PELIANO, 2003, p. 246)

É curioso notar que, aqui, também aparece a questão da motivação religiosa presente em muitos trabalhadores dos abrigos, uma vez que, para os críticos do voluntariado, este pode ser entendido como uma versão laica da caridade católica.

A perspectiva caritativa do voluntariado, segundo seus detratores, apóia-se no entendimento da menor capacidade dos mais pobres. A ajuda dada é uma prática pontual, localizada e feita de uma forma discricionária, geralmente fundada numa apreciação de bom comportamento e num julgamento moral dos pobres. O serviço voluntário é aleatório e entendido como favor. (BEGHIN \& PELIANO, 2003, p. 254)

Sob essa perspectiva, o voluntariado serviria aos interesses das classes dominantes, na medida em que alivia sua culpa em relação à desigualdade social sem, no entanto, alterá-la, já que é uma atuação que não visa transformar suas estruturas mais fundamentais. Em outras palavras, o voluntariado serviria apenas para "administrar" a pobreza. 
De outro lado, os defensores do voluntariado acreditam que é possível concebê-lo de uma forma diferente: baseado na ideia de participação, esse voluntariado não prescinde da ação estatal, mas parte do reconhecimento de que ela é insuficiente sozinha. A proposta é de união entre Estado e sociedade civil, inaugurando "um novo contrato social onde a cidadania tanto se constitui na obrigação política vertical entre os cidadãos e o Estado, como na obrigação horizontal entre os cidadãos” (BEGHIN \& PELIANO, 2003, p. 246).

Não é de interesse deste trabalho tomar posição a respeito do debate proposto, mesmo porque não haveria a oportunidade de se fundamentar os posicionamentos particulares de modo aprofundado. No entanto, é importante para os objetivos deste estudo observar alguns reflexos dessa discussão na composição dos trabalhadores voluntários dos abrigos.

Para iniciar essa caracterização, pode-se citar um dado do Levantamento Nacional, que aponta terem $64 \%$ dos abrigos declarado que possuem pelo menos um voluntário em quadro de funcionários (cf. BEGHIN \& PELIANO, 2003, p. 259).

No entanto, ressalte-se que a imensa maioria (88\%) dos abrigos que declararam possuir profissionais voluntários é não-governamental e que, destes, grande parte (78\%) são instituições confessionais (cf. BEGHIN \& PELIANO, 2003, p. 261). Sendo assim, é possível afirmar que, nos abrigos, a vinculação entre voluntariado e motivação religiosa se mantém.

Em relação à capacitação, a pesquisa da AASPTJ-SP/NCA-PUCSP/SAS/Fundação Orsa (2003) revelou que mais da metade (54\%) dos abrigos de São Paulo não possui um programa sistemático de capacitação de seus funcionários (p. 136). É interessante que os índices de supervisão sejam de $80 \%$, o que é de se estranhar, pois capacitação e supervisão costumam estar associados. A inquietação apontada se esclarece quando se percebe que

[...] as críticas referem que essa ação deveria atender menos as necessidades da Secretaria, em geral vinculadas ao controle da manutenção das despeças, tendo sido caracterizada como uma ação de caráter fiscalizatório e burocrático, devendo ser mais voltada para as necessidades dos abrigos. A demanda identificada nas respostas é por maior troca profissional, viabilização de capacitação e suporte psicológico para os funcionários. (AASPTJ-SP/NCA-PUCSP/SAS/FUNDAÇÃO ORSA, 2003, p. 139)

Tal situação é reveladora de que a política de conveniamento, pelo menos na cidade de São Paulo (apesar deste estudo considerar que tal situação é emblemática e certamente se reproduz em vários outros municípios) não tem se configurado como uma parceria, com 
divisão de tarefas e responsabilidades, tal como previa o Plano de Assistência Social da Cidade de São Paulo (PLASsp) (2002/2003):

\begin{abstract}
Ao contrário de uma relação de compra e venda, como é o caso dos serviçosmeio terceirizados, o convênio significa cooperação, parceria e mútua expectativa de contrapartida. O próprio termo convênio - "cum venire" significa vir com ou vir junto. A relação do conveniado com o conveniante não é de cliente ou de consumidor, mas de parceiro na realização de um programa ou projeto, cujos resultados e alcance social constituem expectativa de ambos. Trata-se de somar, combinar e articular diferentes recursos - na forma de contrapartidas - de modo a atingir propósitos comuns. (PLAsp apud AASPTJ-SP/NCA-PUCSP/SAS/FUNDAÇÃO ORSA, 2003, p. 84)
\end{abstract}

Isso porque o conveniamento prevê para o poder público não só o repasse financeiro e seu controle de despesas, mas também o acompanhamento, a orientação e a supervisão dos aspectos teóricos, éticos e metodológicos da execução dos serviços, o que não vem acontecendo plenamente, segundo a pesquisa supracitada. Na realidade, em síntese, "foi possível constatar a correlação entre a ação de fiscalização e a de supervisão, parecendo que ambas se confundem na relação interinstitucional" (AASPTJ-SP/NCAPUCSP/SAS/FUNDAÇÃO ORSA, 2003, p. 139), sinalizando que essas instituições costumam ser mais cobradas do que apoiadas, o mesmo acontecendo com as supervisões/fiscalizações da VIJ, Conselho Tutelar e Ministério Público.

Por outro lado, "alguns abrigos deixaram claro sua não disposição de manter convênio com o governo estadual e municipal, como modo de evitarem a interferência destes na organização do trabalho que realizam" (AASPTJ-SP/NCA-PUCSP/SAS/FUNDAÇÃO ORSA, 2003, p. 159). Esses abrigos são, normalmente, aqueles que possuem capacidade de se sustentar com seus próprios recursos.

Fica claro que, tanto para os abrigos que desejam o convênio com o Poder Público como os que não o desejam, os governos não são parceiros no atendimento que realizam. No primeiro caso, percebe-se que essas instituições buscam no convênio não apenas o recurso financeiro, mas também o apoio técnico. No segundo caso, o apoio técnico, ao contrário de ajudar, é visto como interferência no trabalho da entidade. Tal situação é grave, pois parece indicar que alguns abrigos consideram que, se não recebem apoio financeiro, estão autorizados a trabalharem de acordo com suas próprias regras, como se os princípios do 
Estatuto e todas as orientações dos demais marcos regulatórios valessem somente para aqueles que possuem financiamento público.

\section{$\underline{\text { 5.1.6 A preservação dos vínculos familiares }}$}

Para conhecer o empenho dos abrigos em garantir a manutenção dos laços familiares, foi verificado se as instituições pesquisadas desenvolviam dois tipos de ações: a) ações de incentivo à convivência das crianças e dos adolescentes com suas famílias de origem; e b) cumprimento do princípio de não-desmembramento de grupos de irmãos abrigados (cf. IPEA, 2003, p. 8). Tal princípio é extremamente importante, pois a separação dos irmãos no momento do abrigamento pode agravar a sensação de abandono.

Como indicadores do primeiro grupo de ações, o Levantamento Nacional (2003) avaliou se os abrigos pesquisados promovem visitas das crianças e dos adolescentes aos lares de suas famílias e se permitem visitas livres dos familiares ao abrigo (cf. IPEA, 2003, p. 9).

Em relação ao primeiro indicador proposto, 68,6\% dos abrigos responderam que promovem visitas das crianças e dos adolescentes aos lares de suas famílias (cf. IPEA, 2003, p. 9). No entanto, tal informação não nos parece muito significativa, na medida em que, pela forma da pergunta, não identifica quantos abrigados efetivamente visitam seus familiares. Nesse ponto, a pesquisa realizada na cidade de São Paulo é mais esclarecedora, indicando que $62 \%$ dos atendidos não passam finais de semana ou férias escolares na residência de seus familiares (cf. AASPTJ-SP/NCA-PUCSP/SAS/FUNDAÇÃO ORSA, 2003, p. 195).

Como forma de compreensão desse dado, o estudo sugere que

[...] o indicativo de que $32 \%$ passam fim de semana ou férias com familiares aponta para uma tendência de prática dos abrigos semelhante a dos internatos, o que por um lado sugere a preservação da convivência familiar, mas por outro leva ao questionamento: "se a família pode levar os filhos para fim de semana ou férias, porque não assumi-los integralmente? (AASPTJSP/NCA-PUCSP/SAS/FUNDAÇÃO ORSA, 2003, p. 195)

Este estudo não concorda com essa interpretação. Uma prática semelhante aos internatos aparece em diversos outros pontos do trabalho dos abrigos, mas não nesse. Considera-se que é muito diferente assumir integralmente um filho do que só levá-lo aos 
finais de semana. No entanto, entendemos o questionamento da referida pesquisa como uma exigência de que as saídas de final de semana estejam inseridas dentro de um projeto maior com objetivo de desabrigamento, ou seja, elas não podem ser tomadas como fins em si mesmos, mas como meios para a desinstitucionalização.

Assim, elas devem ser concebidas como mais um passo da família no sentido da reintegração daquele que se encontra segregado. Um passo mais avançado, há que se reconhecer, do que simplesmente as visitas da família no abrigo. A avaliação do processo de saída das crianças e dos adolescentes abrigados para a casa de seus parentes é um indicador mais importante do que a das visitas no abrigo, pois o primeiro é uma situação menos artificial, ou seja, mais semelhante à realidade da convivência familiar.

Dados levantados por Silva \& Mello (2003) acerca do regime de permanência das crianças e dos adolescentes nos abrigos apontam que 78,4\% dessas instituições trabalham com o regime de permanência continuado, no qual os atendidos ficam no abrigo o tempo todo. Uma minoria dos abrigos (5,8\%) funciona em regime no qual as crianças e os adolescentes passam a semana na instituição e os finais de semana com a família, e apenas 12,2\% trabalham com o regime misto (p. 93).

Tais porcentagens apontam para o descumprimento do princípio do desligamento gradativo (art. 92, inc. VIII do ECA), já que a possibilidade da criança ou do adolescente ir passar os finais de semana na casa de seus familiares é um importante instrumento de preparação para o desabrigamento. O fim de semana na família é, muitas vezes, a melhor "experiência" que o técnico do abrigo tem para avaliar se aquele grupo familiar está pronto para a convivência em tempo integral.

Além disso,

[...] o regime de permanência praticado pelas instituições que oferecem programas de abrigo é um aspecto importante a ser considerado na avaliação desses serviços, pois sua flexibilidade pode ser um valioso instrumento para incitar a convivência familiar das crianças e dos adolescentes abrigados. Um regime de permanência não-rígido pode facilitar a transição entre a fase da institucionalização e o retorno à família, que tem um tempo para se reorganizar sem perder o contato com a criança ou adolescente. (SILVA \& MELLO, 2003, p. 93)

Parece correto afirmar que, na realidade, $100 \%$ dos abrigos deveriam possuir o regime misto de permanência, uma vez que o fator decisivo da utilização de um ou de outro não deve pertencer ao âmbito da instituição, mas sim dos motivos que resultaram na necessidade da 
criança ou do adolescente ir para o abrigo. É a história de quem será atendido e não da instituição que deve determinar o regime de permanência. Além disso, ao longo do processo de acolhimento, os regimes de permanência podem (ou devem) mudar. Aquela criança ou adolescente que se encontrava impossibilitado, pelos mais variados motivos, de conviver com sua família, após as intervenções da equipe do abrigo, pode iniciar, nos finais de semana, a reconviver com seus familiares, com vistas ao convívio em tempo integral.

O segundo indicador proposto é bastante interessante, pois não é tão óbvio quanto o primeiro. Em muitos abrigos, o "dia de visita" é algo tão habitual que ninguém se questiona sobre esse modo de organizar a vinda dos familiares à instituição. Talvez seguindo um modelo prisional, normalmente se elege um dia por semana, geralmente o domingo, e um horário para o encontro da criança ou adolescente abrigado com sua família. Não se leva em consideração que o dia ou horário estabelecido pode não ser o mais viável para a família ir até o abrigo. Ou ainda que esse regime de dias fixos pode restringir o número de visitas de um familiar que pudesse ir ao abrigo mais vezes do que o especificado. A visita livre, ou seja, sem datas e horários pré-estabelecidos, é indicador da flexibilidade da instituição para se adequar ao melhor horário para sua demanda e não para si mesma. Ora, se um abrigo deve se esforçar ao máximo para preservar os vínculos familiares, deve então compreender as dificuldades de deslocamento das famílias pobres, que geralmente dispõem de péssimas alternativas de transporte coletivo. Minha sugestão é que o regime de visitas (frequência e horário) seja acordado com cada família em particular, criando um programa singular para cada caso, balanceando tanto as necessidades da instituição como as da família.

Nos abrigos da cidade de São Paulo, apenas 21,6\% deles indicaram certa flexibilidade nessa questão. Em 48,5\% a visita é semanal, em 17,5\% é quinzenal e em 8,2\% deles a frequência é mensal (cf. AASPTJ-SP/NCA-PUCSP/SAS/FUNDAÇÃO ORSA, 2003, p. 124). A mesma pesquisa ainda ressalta a inadequação das visitas quinzenais e mensais apontando que até

[...] o adolescente autor de ato infracional, que esteja cumprindo a medida sócio-educativa de internação, tem o direito de visita semanal (conforme parágrafo VII do art. 124 do ECA), o que leva a supor que, ressalvadas as particularidades de cada situação, esta também deveria ser uma garantia para os que estão sob medida de proteção nos abrigos. (AASPTJ-SP/NCAPUCSP/SAS/FUNDAÇÃO ORSA, 2003, p. 125) 
Mais grave ainda são os 4,1\% dos abrigos que não permitem visitas, alegando as justificativas mais preconceituosas ("por não considerar segura a vinda de familiares") ou ainda totalmente desinformadas a respeito do papel do abrigo ("pelo fato do abrigo não visar à reintegração familiar") (cf. AASPTJ-SP/NCA-PUCSP/SAS/FUNDAÇÃO ORSA, 2003, p. 126).

Ainda em relação às visitas

[...] é importante assinalar ainda que metade dos abrigos (50\%) afirmou ter como critério solicitar autorização judicial para a realização de visitas por parte dos familiares, questão essa que requer discussão com as instituições que fazem parte da rede de atendimento, visto que a preservação do vínculo familiar é um princípio estabelecido pelo ECA. Existem as crianças e adolescentes que não devem receber visitas familiares (casos de maus-tratos, destituição do poder familiar, etc.). Em tese, esses é que deveriam ter comunicação judicial (proibição de visitas) (AASPTJ-SP/NCAPUCSP/SAS/FUNDAÇÃO ORSA, 2003, p. 126)

A pesquisa propõe uma inversão na lógica da relação entre visitas no abrigo e autorização judicial: ao invés de se pedir autorização para realizá-las, deve-se somente recorrer ao juiz para impedi-las. Logicamente que, no primeiro caso, a presença de qualquer familiar visitando crianças e adolescentes no abrigo deve ser informada ao Judiciário, bem como a evolução dessa interação. No entanto, a plena instauração da proposta realizada por AASPTJ-SP/NCA-PUCSP/SAS/Fundação Orsa (2003) marcaria um avanço do processo de desjudicialização do atendimento à criança e ao adolescente abrigado, por meio do empoderamento das equipes técnicas dos próprios abrigos.

Das crianças e adolescentes que estão abrigados [na cidade de São Paulo] e que possuem família, 66\% recebem visitas, mas também é significativa a quantidade dos que não recebem, levando a questionar quais os fatores que influenciam para que mesmo existindo família, deixe de haver contato entre eles. (AASPTJ-SP/NCA-PUCSP/SAS/FUNDAÇÃO ORSA, 2003, p. 148)

Sob o ponto de vista deste trabalho, a visita estruturada de modo inflexível, espaçada e dependente da autorização judicial é um dos componentes que ajudam a compreender o questionamento apontado anteriormente.

A pesquisa de Fávero, Vitale e Baptista (2008), também realizada na cidade de São Paulo, ao estudar famílias de crianças e adolescentes em situação de abrigamento, encontrou 
um índice bem maior: aproximadamente $90 \%$ se faziam presentes à visita o que, segundo as pesquisadoras, "indica a existência de interesse, afeto e desejo de manter vínculos" (p. 41). Por que essa diferença tão acentuada entre ambos os estudos. A hipótese aqui apresentada vai no sentido de indicar que a pesquisa de Fávero, Vitale e Baptista (2008) tomou como sujeitos privilegiados de sua investigação justamente os familiares de crianças e adolescentes abrigados que realizam visitas aos abrigos, ou seja, aqueles familiares cujas instituições de acolhimento conseguiam manter algum tipo de relação. Desse modo, o dado aqui apresentado fica sem sentido, pois se escolhe aquelas famílias que visitam seus filhos no abrigo para depois descobrir que elas se esforçam para manter o vínculo? Ora, isso já era pressuposto da pesquisa, de onde ela partiu.

Nesse ponto, as pesquisadoras “descobrem” o que já estava dado desde o início, o que, da perspectiva do presente estudo somente indica a dificuldade que ainda se tem de encontrar meios para se aproximar dessa significativa parcela de famílias de crianças e adolescentes abrigados que não realizam visitas e se recusam a qualquer contado com seus filhos e mesmo com a instituição de acolhimento. As dificuldades encontradas na pesquisa de Fávero, Vitale e Baptista (2008) pode indicar que o caminho de acesso a essas famílias não seja por meio de suas visitas à instituição de acolhimento. Talvez a possibilidade se encontre em vias comunitárias, ou seja, é o abrigo que deve ir até essas famílias e não o contrário. ${ }^{26}$

Existem ainda as dificuldades dos próprios familiares, com destaque para " $72 \%$ que se referem à falta de dinheiro para transporte e/ou distância entre a moradia da família e o abrigo" (AASPTJ-SP/NCA-PUCSP/SAS/FUNDAÇÃO ORSA, 2003, p. 193). Tal fato coloca uma questão a respeito de se a política de acolhimento deveria prever uma verba específica para o transporte dos familiares ou se isso representaria uma forma de assistencialismo. Mas, na realidade, considera-se esta uma falsa questão, uma vez que ela só existe porque atualmente o atendimento em abrigos ainda é desregionalizado.

Assim, o foco da política não deve ser se se deve ou não pagar a passagem de ônibus para os familiares visitarem seus filhos, mas sim como regionalizar o atendimento o mais rapidamente possível, pois a regionalização vai extinguir, ou pelo menos diminuir muito, a necessidade de grandes deslocamentos para a concretização das visitas.

\footnotetext{
${ }^{26}$ Em relação à pesquisa acadêmica, supõe-se que o estudo dessas famílias agressoras não será viável a partir dos grandes estudos quantitativos, mas sim de pesquisas qualitativas baseadas na própria prática cotidiana dos abrigos com essa população de difícil acesso. Tem-se pensado, inclusive, em estudos de caso, metodologia comum na psicologia clínica, por exemplo, mas que ainda não é tão presente na psicologia social e comunitária.
} 
Em relação ao segundo conjunto de ações consideradas, o não-desmembramento de grupos de irmãos, foi avaliado se os abrigos priorizam a manutenção ou reconstituição de grupos de irmãos, se se organizam sob o modelo do agrupamento vertical (diferença superior a dez anos entre a idade máxima e mínima de atendimento) e se atuam em regime de coeducação (meninos e meninas juntos) (cf. IPEA, 2003, p. 9). De fato, se um abrigo só atende meninos ou meninas ou ainda uma determinada faixa etária, como acolhe irmãos de sexos diferentes ou de idades distintas?

A pesquisa da AASPTJ-SP/NCA-PUCSP/SAS/Fundação Orsa (2003) faz um inventário das razões para a separação dos irmãos:

[...] constatou-se que os motivos relacionam-se aos critérios de seleção (especialmente pela diversidade relativa ao sexo e idade), ausência de vagas, necessidade de atendimento especializado para algum membro do grupo de irmãos (portador de HIV ou de deficiência mental). Algumas respostas indicaram ainda, como motivo da separação entre eles, o abrigamento em épocas diferentes e, outras, a desvinculação entre eles. (p. 186)

É importante frisar que nenhuma das razões apontadas se sustenta à luz da legislação. Os argumentos relativos a critérios de seleção e necessidade de tratamentos especiais não mais se justificam frente às novas recomendações de atendimento universalizado. A ausência de vagas é algo que se pode aceitar, mas apenas temporariamente, ou seja, assim que algum atendido sai, a prioridade deve ser receber o irmão de quem permanece na instituição ao invés de um atendido novo. O "abrigamento em épocas diferentes" parece muito mais um sintoma da inflexibilidade da rede de abrigos e do seu despreparo para lidar com as situações complexas do cotidiano. O motivo de "desvinculação" parece o mais injustificado de todos, na medida em que expõe uma inaptidão para uma das tarefas essenciais dos abrigos, não apenas no que se refere aos irmãos, que é a criação ou reconstrução de vínculos. A inexistência presente de vínculos não deve ser motivo para não investirmos em uma possível existência de vínculos no futuro.

Retomando as conclusões do Levantamento Nacional, percebe-se, de modo um tanto assustador que, ainda que tenham sido encontrados índices elevados em alguns critérios isoladamente, apenas 6,6\% desenvolvem todas as atividades em conjunto (IPEA, 2003, p. 8). Esse resultado é um flagrante de que os abrigos estão muito longe de realizar a contento sua função na reintegração familiar, o que, mais uma vez, aponta para o descumprimento do princípio da provisoriedade estabelecido pelo ECA. 


\title{
$\underline{5.1 .7 \mathrm{O} \text { apoio à reestruturação familiar }}$
}

Outro aspecto importante na avaliação da garantia do direito à convivência familiar em instituições de abrigo é o apoio que estas promovem à reestruturação das famílias de seus atendidos.

\begin{abstract}
A reestruturação familiar envolve fatores complexos, como o desemprego, por exemplo, que dependem muito mais de políticas públicas do que das próprias instituições de abrigo. No entanto, essas entidades podem [...] estabelecer a conexão com outras políticas e com a rede de proteção social. (IPEA, 2003, p. 10)
\end{abstract}

Nesse sentido, os abrigos devem funcionar como centros catalisadores de encaminhamentos para os demais serviços da rede de apoio, talvez até dispondo de prioridade nesses encaminhamentos. Daí a crucial importância dos funcionários dessas instituições conhecerem profundamente os recursos de sua cidade, sejam públicos ou privados, que possam auxiliar a família dos abrigados a se reestruturar.

A questão da prioridade no atendimento é complexa e não há unanimidade entre os autores. No entanto, este estudo concorda com Aquino (2003), que aponta que quando não há prioridade no atendimento de crianças e adolescentes submetidos a programas de proteção especial tal fato, além de indicar uma violação de seus direitos,

[...] acaba por sobrecarregar os próprios programas de abrigo que, na ausência de complementariedade por parte dos serviços públicos, têm que assegurar também toda a alimentação, os medicamentos, as oportunidades de lazer, etc. (p. 346)

A pesquisa de Fávero, Vitale e Baptista (2008) discute essa mesma questão em relação ao acesso das famílias de crianças e adolescentes abrigados a programas sociais, concluindo que

[...] os programas sociais existentes (que deveriam ser universalizantes), embora sejam seletivos e focalistas, estranhamente não elegem como parte de seus públicos-alvos prioritários famílias que possuam crianças e adolescentes abrigados - fato que revela, uma vez mais, o baixo grau de articulação entre as políticas setoriais: por um lado existe o PNCFC e, por 
outro, programas sociais que em seu desenho e concepção ignoram o fato de milhares de crianças e adolescentes viverem a privação da convivência familiar. (FÁVERO, VITALE \& BAPTISTA, 2008, p. 109)

As autoras defendem a inclusão prioritária de famílias que possuem crianças e adolescentes abrigados em programas sociais, principalmente se lembrarmos que falta de recursos materiais ainda é a grande causa de abrigamento no Brasil. Sem a articulação da política de abrigamento com as políticas de transferência de renda, por exemplo, dificilmente a "cultura de institucionalização" poderá ser superada.

Em relação à prioridade de atendimento, a pesquisa da AASPTJ-SP/NCAPUCSP/SAS/Fundação Orsa (2003) revelou uma fala comum entre os profissionais dos abrigos: existe "a possibilidade de atendimento diferenciado de alguns serviços com relação ao abrigo, por "entenderem a situação"” (p. 161). Nesse caso, o atendimento prioritário não se constituiu em um direito, sendo conseguido com base na piedade, como um favor.

Mas, de fato, muitos abrigos acabam se sentindo sozinhos na tarefa de proteger e educar de maneira integral as crianças e os adolescentes que estão sob sua responsabilidade. Um exemplo dessa "solidão institucional" pode ser dado a partir da informação de que, segundo Fávero, Vitale e Baptista (2008), 91\% das famílias de crianças e adolescentes abrigados que recebiam algum beneficio de programas assistenciais não realizavam trabalho social algum em conjunto com o recebimento do recurso (p. 91).

Tal sensação é aprofundada pela própria especificidade do serviço de acolhimento institucional, no que se refere à sua característica de moradia, ainda alternativa e provisória. Enquanto nos demais serviços a criança ou o adolescente passa um período reduzido (passa no médico, passa no psicólogo, passa pela escolinha de futebol etc.) é no abrigo ela permanece por um tempo mais prolongado, sendo também no abrigo que expressará seus conflitos e insatisfações.

Baseado em experiência própria, posso afirmar que é muito comum a criança ou o adolescente se comportar de modo extremamente diferente dentro e fora do abrigo, ou melhor, comporta-se "bem" fora do abrigo e "mal" dentro dele. Além de todos os processos característicos da institucionalização, considera-se que o que foi descrito acima possa contribuir para se compreender tal fenômeno, o que ajudaria, em alguns casos, a rever certos preconceitos que os demais serviços da rede de proteção têm a respeito dos abrigos.

Retomando a linha argumentativa principal desse item, pode-se afirmar que a função do Executivo, principalmente o municipal, 
[...] é a de propiciar as condições necessárias para que sejam revertidos, com segurança, os motivos que levaram à aplicação de medida de abrigo para aquela criança e aquele adolescente, providenciando o acesso deles e de suas famílias (como fonte de proteção) à habitação, saúde, educação formal, geração de emprego e renda e atendimento psicossocial. (CARREIRÃO, 2003, p. 309)

$\mathrm{O}$ abrigo não pode ser visto como uma medida de enfrentamento à pobreza e nem como um serviço que deve dar conta das sobras das demais políticas sociais. Fica claro que o abrigamento é uma política que atua nas consequências de um problema. O abrigamento é uma política de enfrentamento da violência contra crianças e adolescentes, que pode ou não advir da pobreza.

E ainda, quando nos debruçamos sobre a origem da questão da violência contra a criança e o adolescente, o que leva para a questão da violência na sociedade em geral, e se depara com a desigualdade social, a opressão econômica e a negligência do Estado, compreende-se que os abrigos, por melhores que sejam, estarão sempre atuando nas consequências da violência e nunca em suas causas.

O abrigo, assim, acaba por substituir medidas preventivas - por ausência ou ineficiência - determinando a privação da convivência familiar por motivos que poderiam ser sanados com políticas e programas voltados à promoção da família, de forma a evitar o abrigamento. (SILVA \& MELLO, 2003, p. 37)

Em uma metáfora um tanto simplista, ela exerce a função do "bombeiro" dentro das políticas sociais dirigidas às famílias pobres: visa apagar incêndios, mas não cuida para que novos incêndios não ocorram. Outra metáfora que poderia ser construída nesse sentido é a de "UTI social”. Em um hospital, quando um paciente é encaminhado para a UTI, isso significa que seu caso é grave e que ele necessita de um tratamento intensivo. Essa ideia de algo "intenso" deveria ser compreendida como o ideal de um trabalho em abrigos. Nessas instituições, assim como nas UTIs, o objetivo não é cuidar de um grande número de casos, mas somente daqueles mais graves e que requerem atenção especial. Como um tratamento de grande intensidade, não se deve conceber o trabalho em abrigos como algo que deve se estender por um longo tempo. E, finalmente, assim como as UTIs, o serviço oferecido pelos abrigos é caro e não tem a especificidade de ser producente no que se refere à prevenção de 
novos casos de violência. Assim, o poder público não pode deixar de investir nas causas do problema e ter como estratégia de prevenção o apoio ao conjunto familiar como um todo.

Caso contrário, a política social se torna "hipócrita", pois

[...] desemprega os pais e cria abrigos e asilos para os filhos, arrocha o salário dos pais e dá pão e leite para os filhos, impede o acesso das famílias pobres aos alimentos básicos e anuncia planos de combate à mortalidade infantil. (SOUZA apud RIZZINI \& WIIK, 1990)

É ciclo vicioso: o Estado abandona as famílias que, por sua vez, abandona seus filhos. Para solucionar esse problema, ao invés de apoiar efetivamente as famílias, o Estado cria instituições que, sem as devidas condições para trabalharem, tornam-se elas próprias abandonadas e passam a apenas reproduzir o sintoma que as gerou.

O que espanta ainda mais é que nem em termos estritamente financeiros o abrigamento é uma medida vantajosa para a sociedade. É o que indica a pesquisa da AASPTJSP/NCA-PUCSP/SAS/Fundação Orsa (2003), que analisou a realidade econômica dos abrigos da cidade de São Paulo e constatou que,

[...] apesar da diversidade entre eles, os dados financeiros apresentados comprovam a antiga noção de que a manutenção da criança e do adolescente é mais dispendiosa no abrigo do que seria se houvesse maior efetividade dos programas de apoio à convivência familiar (p. 88),

desafiando os pesquisadores a encontrarem outros motivos para essa "opção social" pela institucionalização. Sendo assim, toda discussão sobre aumento do valor de convênios, aumento do repasse de recursos, enfim, aumento do gasto financeiro com abrigos deve ser feita com cautela, tendo em vista que é mais barato prevenir o abrigamento do que bancar o elevado custo de manutenção da criança ou do adolescente na instituição.

A lógica aqui é parecida com a relação entre investimentos em saneamento básico e investimentos em saúde. É sabido que os recursos gastos no primeiro retornam sob a forma de economia nos gastos com o segundo, pois boas condições de saneamento geram diminuição de demanda para a saúde, ou seja, as pessoas ficam menos doentes.

Ora, bons programas de apoio familiar, apesar de não extinguirem completamente a demanda de abrigamento, gerariam uma sensível diminuição dessa última, com a vantagem de serem bem mais baratos. No item dedicado ao financiamento, expôs-se que o custo médio/mês por atendido, em nível nacional, gira em torno de $\mathrm{R} \$ 508,14$ para os abrigos 
públicos e R $\$ 365,51$ para os privados. Na cidade de São Paulo esses valores são ainda maiores, chegando a $\mathrm{R} \$ 1.500,00$, como valor de referência para a Secretaria, do custo médio da criança ou adolescente em abrigo para o convênio municipal (AASPTJ-SP/NCAPUCSP/SAS/FUNDAÇÃO ORSA, 2003, p. 83). Será que com esse apoio financeiro, aliado a um bom trabalho de acompanhamento psicossocial, que parte desse recurso também poderia bancar, muitas dessas famílias não precisariam ter seus filhos abrigados?

Note-se que o se está propondo não é um acréscimo de gastos. O que se sugere é, a partir de uma mudança de cultura, uma mudança de proposta de atendimento à população com demanda de acolhimento institucional, mude-se a maneira como esses recursos são gastos.

Para o trabalho de apoio à reestruturação familiar, talvez se possa elencar como princípio norteador

[...] uma concepção ampla de proteção integral, a qual, de um lado, vai além das próprias crianças e adolescentes em situação de risco, incorporando também as suas famílias e, de outro, extrapola os serviços de urgência e proteção especial, incluindo também o acesso às políticas sociais básicas como ações de retaguarda essenciais. (AQUINO, 2003, p. 345)

Sobre as situações de violação de direitos, o ECA e o PNCFC trabalham com a ideia de corresponsabilidade do Estado, da família e da sociedade, prevendo que a violência no interior da família pode "refletir, ainda que não necessariamente, também uma situação de vulnerabilidade da família diante dos seus próprios direitos de cidadania, do acesso e da inclusão social"' (2006, p. 34).

É por isso que, em diversos pontos do PNCFC, também se ressalta a importância das medidas voltadas à inclusão das famílias em programas de auxílio e proteção. "Tais programas, se disponíveis e bem estruturados, podem lograr a superação das dificuldades vivenciadas pela família e a restauração de direitos ameaçados ou violados, sem a necessidade de afastar a criança ou adolescente do seu núcleo familiar" (PNCFC, 2006, p. 37).

No entanto, o Plano vai mais longe, indicando quais são as dimensões que esses programas devem, a partir da singularidade de cada família e de modo participativo, necessariamente incluir: superação das vulnerabilidades sociais decorrentes da pobreza incluindo condições de habitabilidade, segurança alimentar e trabalho; fortalecimento dos vínculos familiares e de pertencimento social fragilizados; orientação da família quanto ao adequado exercício das funções parentais; superação dos conflitos relacionais e/ou 
transgeracionais, rompendo o ciclo de violência; integração sociocomunitária a partir da mobilização das redes sociais e da identificação de bases comunitárias de apoio e orientação jurídica, quando necessário (cf. PNCFC, 2006, p. 39).

Aqui estão elencadas, ponto a ponto, as tarefas que uma metodologia de trabalho com as famílias em situação de vulnerabilidade terá que dar conta. É importante pensar no desenvolvimento de estratégias de intervenção para cada um dos itens propostos no Plano.

Tendo a interdisciplinaridade e a intersetorialidade como características fundamentais, os programas de apoio sociofamiliar devem articular as diferentes políticas sociais básicas e constituem um dos pilares do PNCFC: "falar da qualidade de vida de crianças e adolescentes é falar da qualidade de vida de suas famílias e nas suas famílias” (2006, p. 48).

No entanto, sob o ponto de vista do presente trabalho, esses programas são mais eficazes na tarefa de prevenir a violência do que na de interrompê-la depois que ela já se instaurou na dinâmica familiar. Para esses casos, considera-se necessário o desenvolvimento de um programa mais específico de apoio familiar, que pode seguir os mesmo princípios gerais apontados no PNCFC, mas que necessita de uma metodologia própria. Esse ponto será retomado no capítulo final desta pesquisa.

Apesar das diretrizes e das recomendações citadas, o que se percebe no cotidiano é a ausência ou insuficiência das políticas sociais básicas, particularmente desses programas de apoio sociofamiliar destacados como tão essenciais, o que está intrinsecamente associado às situações de violência que levam ao abrigamento, fazendo do Estado o principal violador de direitos de crianças e adolescentes. Outros exemplos podem ser levantados, como o que se depreende da leitura de Rizzini e Wiik (1990), na qual se salienta o importante caráter preventivo ao abrigamento de uma rede de creches bem constituída, possibilitando que os pais trabalhem sem ter que "abandonar" seus filhos durante esse período.

Esse é mais um dos paradoxos da pobreza: pais que abandonam seus filhos para conseguir sustentá-los. Nesses casos, a criança ou adolescentes não necessitaria ser institucionalizada. A respeito dos Centros de Atenção Diária (CADs), instituições semelhantes às creches, Silva \& Mello (2003) falam da

[...] importância dessas instituições para as famílias de baixa renda, uma vez que representam suporte para que mães, pais ou responsáveis possam trabalhar fora de casa e, consequentemente, aumentar a renda da família, diminuindo, assim, as causas de abandono de crianças e adolescentes em abrigos. (p. 94) 
Outro exemplo da falta de apoio das demais políticas sociais, dessa vez na área da saúde, pode ser apontado quando se verifica que a maior parte do atendimento odontológico e psicológico das crianças e dos adolescentes abrigados se concentra no âmbito privado (cf. AASPTJ-SP/NCA-PUCSP/SAS/FUNDAÇÃO ORSA, 2003, p. 146). Em outras palavras, para o abrigo propiciar esses serviços (e imagine-se a importância de acompanhamento psicológico para essa população) aos seus atendidos ou terá que pagar ou ficará na dependência da boa vontade de algum voluntário.

A falta de apoio da rede de políticas sociais tem gerado também um movimento de retrocesso no que se refere à participação das crianças e dos adolescentes abrigados na vida da comunidade local,

[...] o que fica evidenciado ao se verificar a demanda das entidades por profissionais da área médica. Provavelmente, os abrigos entendem que a contratação de profissionais dessa área possibilite a superação dos problemas decorrentes da pouca eficácia dos serviços prestados na área da saúde. (AASPTJ-SP/NCA-PUCSP/SAS/FUNDAÇÃO ORSA, 2003, p. 161)

Face às péssimas condições das políticas públicas de um modo geral, ao invés da luta pela efetiva implantação de uma rede de serviços de qualidade, alguns abrigos estão optando pelo retorno a modelos antigos de atendimento, nos quais cada instituição, congregando uma série de serviços dentro de si, funcionava como um "pequeno Estado".

Considera-se este dado como decorrente da falta de compreensão a respeito da incompletude institucional, pois o abrigo por si só, não pode dar conta de todas as expressões da questão social, nem qualquer instituição isoladamente. (AASPTJ-SP/NCA-PUCSP/SAS/FUNDAÇÃO ORSA, 2003, p. 161)

No que concerne de modo mais estrito às instituições de abrigo, os critérios utilizados pelo Levantamento Nacional na verificação do apoio à reestruturação familiar foram: se realizam visitas domiciliares; se oferecem acompanhamento social; se organizam grupo de discussão e apoio; e se encaminham a família para programas de auxílio (cf. IPEA, 2003, p. 10).

Cada uma dessas ações tem sua função específica: as visitas domiciliares têm o objetivo de conhecer a realidade da família in loco: as condições da moradia, os recursos da 
comunidade etc. O acompanhamento social visa oferecer as orientações gerais e os encaminhamentos que cada família necessita. Os grupos de discussão, que reúnem várias famílias de abrigados, têm a fundamental importância de incentivar a socialização dos saberes entre aqueles que se encontram em uma situação parecida. Visa, por meio das trocas de informações com os profissionais do abrigo e entre as próprias famílias, construir uma rede de apoio horizontalizada, na qual cada um possa aprender que muitos dos problemas que julga serem individuais também estão presentes na vida de outras pessoas e que as soluções para tais questões costumam ser mais facilmente encontradas no âmbito coletivo. Já os programas oficiais de auxílio podem ajudar a prover o necessário apoio financeiro que muitas dessas famílias precisam.

De acordo com o Levantamento Nacional, apenas 14,1\% dos abrigos pesquisados realizam as quatro ações conjuntamente (cf. IPEA, 2003, p. 10). A revelação deste baixo percentual é importante para percebermos que, se, de maneira mais geral, o Estado não tem cumprido com suas obrigações no que concerne ao apoio sociofamiliar por meio das políticas sociais básicas e o sistema de garantia de direitos não tem colaborado dada à sua desarticulação, os abrigos também não têm realizado a sua parte. Em outras palavras, o quadro geral de deterioração das questões de ordem macrossocial não justificam uma postura de desresponsabilização das instituições de acolhimento, que também possuem defasagens em pontos que seriam de sua atribuição intrínseca.

Além disso, esse quadro é preocupante, uma vez que o apoio à reestruturação familiar é uma condição sem a qual o desabrigamento torna-se inviável. Na realidade, uma política de abrigamento que não promova a reestruturação familiar transforma-se no oposto do que deveria ser: ao invés de colaborar para o fortalecimento dos vínculos fragilizados no interior da família, acaba por contribuir para sua ruptura, sepultando as possibilidades de desabrigamento e naturalizando a institucionalização.

Avaliam-se esses dados como decorrentes da ausência de uma política de desabrigamento, pois o desenvolvimento de trabalhos [com as famílias] isolados e fragmentados, não possibilita o enfrentamento efetivo dessa situação. Não basta orientar ou acompanhar sem possibilitar um mínimo de condições dignas de sobrevivência a essa família. Ademais, os motivos do abrigamento variam e o trabalho de reintegração deve abarcar todos os ângulos da situação que o motivou. (AASPTJ-SP/NCAPUCSP/SAS/FUNDAÇÃO ORSA, 2003, p. 149) 
A política de abrigamento deve ter muito bem definida sua política interna de desabrigamento, com todas as necessárias articulações com as demais políticas públicas, tendo como eixos fundamentais: formação profissional e inclusão dos jovens no mercado de trabalho, auxílio financeiro e programas de geração de renda às famílias, casas de apoio à maioridade, prioridade nas políticas de habitação ou mesmo fácil acesso a materiais de construção para as famílias e centros de apoio à adoção. Tudo isso para que se garanta efetivamente o mínimo tempo necessário de institucionalização.

É nesse sentido da indefinição de uma política de desabrigamento que se nota, por exemplo, a ausência bastante sintomática de dados a respeito da preparação do abrigado para o desligamento. O Levantamento Nacional criou indicadores e quantificou quase todos os nove princípios que regem as entidades de abrigo (art. 92 do ECA), mas silencia-se justamente a respeito da "preparação gradativa para o desligamento" (inc. VIII). Fica-se com a sensação de que os procedimentos dirigidos ao desabrigamento são majoritariamente pensados a partir das possibilidades e das necessidades do momento, caso a caso e de modo muito particularizado, sem a definição de uma estratégia mais ampla de desacolhimento que transcenda as situações individuais e assuma o estatuto de uma política pública.

Tal situação de precarização social das famílias que têm seus filhos abrigados ainda pode ser mobilizadora de um sintoma muito característico:

Dadas as dificuldades que as famílias dos abrigados enfrentam para acessar os serviços públicos de apoio à criação e educação de seus filhos, muitas delas acabam se acomodando ao seu abrigamento, na expectativa de que a institucionalização possa garantir proteção e acesso aos serviços básicos de educação e saúde. (AQUINO, 2003, p. 339)

O importante nesse ponto é compreender que essas famílias não são intrinsecamente acomodadas. Elas tornam-se "acomodadas" como consequência de um trabalho de apoio familiar inexistente ou malfeito. Não se trata de justificar esse costumeiro sintoma de famílias de crianças e adolescentes abrigados, mas sim compreender um dos múltiplos sentidos que pode estar subjacente a essa "acomodação", que passa a poder ser lida como esperança de melhorar a vida de seus filhos.

Certa vez, atendi uma mãe que dizia, quase em tom de ameaça, que se o filho fosse desabrigado ele não teria todas as "mordomias que tinha no abrigo". Ela estava se referindo aos passeios, à perua que levava e buscava e às cinco refeições por dia que os atendidos do 
abrigo em que trabalhava usufruíam. Foi difícil fazê-la entender que, se seu filho tivesse como opções excludentes as "mordomias do abrigo" (entre aspas porque são direitos e não mordomias) e o afeto, cuidado e carinho de sua mãe, ele, sem dúvida, escolheria a segunda opção.

De modo muito sintomático, é comum aparecer nos discursos dos familiares de crianças e adolescentes abrigados uma hipervalorização dos benefícios materiais que o abrigamento costuma proporcionar a seus filhos coligada a uma desvalorização dos prejuízos emocionais.

No entanto, essa visão não se encontra restrita somente à família, contaminando, muitas vezes, os próprios profissionais. Não foram poucas as vezes em que, em reuniões de equipe, levantou-se a questão de que os filhos dos funcionários não tinham tudo o que os abrigados dispunham no abrigo. A conclusão desse tipo de pensamento aparecia da seguinte forma: o abrigo não pode ser "bom demais" a ponto das crianças e dos adolescentes não quererem mais sair dele ou seus familiares desistirem do desabrigamento. Da perspectiva deste estudo, tal modo de concepção é uma inversão total dos pressupostos que deveriam balizar o atendimento em abrigos, pois estão alicerçadas na ideia assistencialista de favor. Favor concebido como uma ação benevolente, feita idealmente somente a quem merece, da qual se espera a retribuição em termos de gratidão.

Está-se diante de uma questão com a qual muitos abrigos terão que lidar em sua prática cotidiana: o que fazer quando a institucionalização fornece melhores condições materiais de vida do que a família? Deve-se cuidar da família para que esta cuide de seus filhos. Ao invés de se concentrar em manter as instituições de acolhimento com um nível ruim de atendimento, a solução deve girar em torno da necessidade de se fortalecer as famílias de origem dos abrigados.

Não se trata de desvalorizar a questão da privação material. O fato é que somente o suprimento desse fator não dá conta das necessidades envolvidas no desabrigamento de uma criança e de um adolescente. Se a política de apoio à reestruturação familiar se limitar a prover apenas o apoio financeiro, estará fadada a desenvolver uma relação assistencialista de dependência dos familiares para com a instituição. A sensibilização da importância da família como lugar de cuidado, amor e socialização é essencial para qualquer trabalho efetivo de desinstitucionalização. 
O estudo da AASPTJ-SP/NCA-PUCSP/SAS/Fundação Orsa (2003) apontou para a inexistência de perspectivas de desabrigamento para 57\% da população que se encontrava nos abrigos da cidade de São Paulo na época da pesquisa (p. 198).

\begin{abstract}
Cruzando esses dados com os gráficos da percentagem daqueles que recebem visitas observa-se que $65 \%$ da população pesquisada recebem visitas, mas $57 \%$ não têm perspectiva de desabrigamento, o que pode indicar que mesmo estando preservado o contato com a família, os fatores impeditivos à reintegração familiar não são superados. Esses fatores podem se reproduzir pela falta de alternativas socioeconômicas que permitam o acesso a condições de vida mais dignas e, possivelmente, sejam perpetuados frente aos índices apresentados de uso de drogas e problemas de saúde mental por parte do pai ou da mãe, sendo mais um indicativo da necessidade de programas específicos para a população, que protejam e efetivem o direito à convivência familiar. (AASPTJ-SP/NCAPUCSP/SAS/FUNDAÇÃO ORSA, 2003, p. 198)
\end{abstract}

Parece que, sem o apoio da rede de proteção e das demais políticas públicas, os abrigos não conseguirão cumprir seu papel de fazer retornar à família aquelas crianças e adolescentes que se encontram sob sua responsabilidade. Sozinhas, essas instituições poderão, na melhor das hipóteses, simplesmente proteger de maneira individualizada, ou seja, cuidarão das crianças e dos adolescentes, mas não do núcleo familiar. Que proteção é essa? Será que proteger de modo descontextualizador, separando pais e filhos sem a certeza de ser capaz de novamente reunir essa família em condições dignas de existência é mesmo proteger?

\title{
$\underline{5.1 .8 \mathrm{O} \text { incentivo à convivência com outras famílias }}$
}

Apesar de ser competência exclusiva da autoridade judiciária o encaminhamento de qualquer criança ou adolescente para uma família substituta nos casos em que foram esgotadas as tentativas de retorno à família de origem, o abrigo tem como função intervir no sentido da "aproximação gradativa e a preparação prévia da criança, do adolescente e dos pretendentes, bem como acompanhamento no período de adaptação" (PNCFC, 2006, p. 72).

No entanto, faz parte do reordenamento institucional desses serviços a execução desse trabalho sob a égide da recusa do "paradigma tradicional segundo o qual a adoção tem a 
finalidade precípua de dar filhos a quem não os têm, estando, portanto, centrada no interesse dos adultos" (PNCFC, 2006, p. 72).

Trata-se de desenvolver uma concepção de adoção centrada no interesse da criança ou do adolescente. Mas o que isso significa exatamente?

\begin{abstract}
Não se trata mais de procurar "crianças" para preencher o perfil desejado pelos pretendentes, mas sim de buscar famílias para as crianças e adolescentes que se encontram privados da convivência familiar. Isso pressupõe o investimento na conscientização e sensibilização da sociedade acerca desse direito das crianças e adolescentes e no desenvolvimento de metodologias adequadas para a busca ativa de famílias adotantes. Trata-se, portanto, de investir para que a adoção seja o encontro dos desejos e prioridades da criança e do adolescente com os desejos e prioridades dos adotantes [...] (PNCFC, 2006, p. 72)
\end{abstract}

A revolução neste processo está no ponto de onde se parte: a adoção não pode mais partir do perfil desejado pelos adotantes, que sabe-se ser, muitas vezes, fruto de preconceitos. Deve iniciar-se em cada criança ou adolescente e em sua necessidade de crescer em uma família. Na busca ativa, são as famílias que devem ser "procuradas". Devem-se procurar famílias para as crianças e não crianças para as famílias.

Essa é a estratégia proposta atualmente para que se alcance o direito à convivência familiar daqueles que aguardam colocação em adoção, mas, "por circunstâncias diversas, têm sido preteridos pelos adotantes - grupos de irmãos, crianças maiores e adolescentes, com deficiência, com necessidades específicas de saúde, afro-descendentes, pertencentes a minorias étnicas e outros" (PNCFC, 2006, p. 45).

A colocação em família substituta é uma forma de garantir a convivência familiar daquelas crianças e adolescentes que não possuem chances de retorno à família de origem. No entanto, o ECA estabelece em seu art. 92, inc. II que tal alternativa somente deve ser praticada quando se esgotarem os recursos de manutenção na família de origem.

Ainda assim,

[...] a colocação em família substituta envolve importantes questões adicionais. No âmbito das entidades, é preciso superar a cultura de que, na ausência da família, o melhor lugar para crianças e adolescentes é uma instituição, onde podem "ter melhores condições de vida" - gerando uma certa "apropriação" de meninos e meninas pelas instituições. (IPEA, 2003, p. 10) 
Na maioria das vezes, por mais carente de recursos financeiros que seja um abrigo, ele consegue propiciar melhores condições materiais aos seus atendidos do que se eles estivessem com suas famílias. Esse fato costuma ser apropriado como justificativa de um sintoma muito característico dessas instituições: o sentimento de posse em relação às crianças e aos adolescentes atendidos. O abrigo passa a funcionar como uma mãe ciumenta, que compete com as outras mães pela posse dos filhos. Ao invés de trabalhar no sentido da reestruturação da família de origem e, quando isso é inviável, na procura de uma família substituta, o abrigo passa a culpabilizá-las pelo abandono e a idealizar seu próprio atendimento. Tal concepção é geradora de institucionalização.

Em um dos abrigos em que trabalhei havia uma separação extremamente rígida entre o trabalho da equipe técnica e a equipe de educadores, no sentido de que somente os primeiros é que estavam autorizados a realizar intervenções com os familiares dos atendidos e, inclusive, somente estes é que tinham acesso aos prontuários das crianças e dos adolescentes abrigados, instituindo uma espécie de ditadura da informação no interior do serviço. Subjacente a essa cisão estava a identificação do técnico com um lugar de poder a partir de um lugar de saber, sem encontrar formas de comunicação que escapassem da armadilha de transformar o necessário sigilo profissional em segredo.

Entretanto, acontecia que a equipe técnica seguia uma escala de trabalho diarista (de segunda a sexta-feira), enquanto eram os educadores que se revezavam em esquema de plantão, ou seja, nas visitas dos familiares ao abrigo, que ocorriam sempre aos domingos, eram os educadores que os recepcionavam. Certa vez, uma educadora veio conversar com a equipe técnica trazendo a opinião de que a mãe de M. deveria ser proibida de vir visitar seu filho, uma vez que esta não dava a atenção que o menino necessitava, inclusive tratando-o muito mal na frente de todos. M. era um menino que sofreu muito quando morava junto com essa mãe e era uma criança muito querida no abrigo por causa de seu comportamento meigo e carinhoso. Logo foi perguntado a essa educadora quais foram as atitudes que ela havia tomado para tentar reaproximar mãe e filho. Ela prontamente respondeu: "Nenhuma". Após uma breve discussão, a educadora saiu da sala taxada de incompetente. No entanto, quem estava sendo incompetente era o abrigo como um todo, baseado em uma divisão de trabalho totalmente esquizofrênica e contraproducente. Se a educadora em questão não sabia nada a respeito da história de vida dessa mãe, como poder-se-ia esperar dela uma atitude compreensiva com os comportamentos agressivos que esta apresentava? 
Nessa situação, a educadora comportou-se de fato como uma "mãe ciumenta", protegendo M. de algo que ela verdadeiramente considerava que estava fazendo mal para o garoto. Como a educadora tinha pouquíssimos elementos (informações) para refletir sobre a situação, acabou atuando tendo como base o conhecimento de que dispunha, ou seja, para ela, era claro que sua função era proteger M., não ficava nítido que também deveria ser sua função educar não somente os filhos, mas também os pais. Atribuindo a poucos profissionais a incumbência de se trabalhar com a família, a instituição gerava um sintoma: se colocar no lugar da família ao invés de fortalecê-la para que pudesse voltar a cuidar de seus filhos.

Mesmo que a colocação em família substituta exija a participação efetiva de outros órgãos importantes, como o Judiciário, o abrigo tem a tarefa fundamental de promover a convivência entre crianças e adolescentes abrigados e outras famílias, desenvolvendo, por exemplo, programas de apadrinhamento.

O apadrinhamento, diferentemente do trabalho voluntário que em geral tem
uma atuação voltada para a população abrigada como um todo, implica na
atenção e/ou contato com uma criança ou adolescente específico. Constatou-
se que $52 \%$ dos abrigos [na cidade de São Paulo] contam com tal programa,
que pode contemplar a assistência financeira e material e/ou a viabilização
de convivência extra-instituição nos fins de semana e/ou feriados. Essa é
uma importante alternativa de vivência extra-institucional, principalmente
para aqueles que não têm mais possibilidade de convivência familiar.
(AASPTJ-SP/NCA-PUCSP/SAS/FUNDAÇÃO ORSA, 2003, p. 146)

Nesses casos de abrigados sem perspectiva de retorno ao convívio familiar, o apadrinhamento pode ser um processo indutor de uma possível adoção, ainda que este não deva ser o principal objetivo do programa, pois, senão, poder-se-ia correr o risco de estar "forçando" uma adoção. No entanto, não se pode deixar de apontar que o apadrinhamento algumas vezes pode ser um primeiro passo, mais descompromissado, de uma aproximação afetiva que pode evoluir até uma adoção. E mesmo quando isso não acontece, possuir um padrinho é algo extremamente importante, por exemplo, para um jovem de 18 anos que acaba de sair do abrigo. É alguém com quem ele pode contar, um apoio inicial para o começo de sua vida sem o abrigo. Nesses casos, o padrinho é uma das figuras que dão corpo ao direito de convivência comunitária.

Apenas 23,8\% cumprem as exigências estabelecidas pelo Levantamento Nacional (incentivar a integração em família substituta em termos de guarda, tutela ou adoção e manter 
programas de apadrinhamento) quanto à questão de incentivo à convivência com outras famílias (cf. IPEA, 2003, p. 11).

Em relação à adoção, a pesquisa na cidade de São Paulo revelou que somente $10 \%$ das crianças e adolescentes abrigados têm situação legal definida que permita que sejam adotados, ou seja, possuem uma sentença judicial de destituição do poder familiar (cf. AASPTJSP/NCA-PUCSP/SAS/FUNDAÇÃO ORSA, 2003, p. 196).

Desses, apenas $7 \%$ têm até um ano, $5 \%$ até dois e $2 \%$ até três, sendo que

[...] a grande maioria dos que legalmente podem ser adotados (84\%) têm entre oito e dezenove anos de idade, ou seja, são aqueles para os quais inexistem (ou quase) candidatos à adoção, o que leva a questionar sobre o significado dessa medida legal na vida deles, apontando-se novamente para a importância junto à família de origem. (AASPTJ-SP/NCAPUCSP/SAS/FUNDAÇÃO ORSA, 2003, p. 196)

A pesquisa paulista aponta o outro lado da questão, pois se se deve incentivar a integração em família substituta, deve-se também ser extremamente cauteloso com esse "incentivo" e a consequente solicitação de destituição do poder familiar, ainda mais quando se recorda que o ECA determina que a adoção é irrevogável (art. 48), ou seja, uma vez feita, não pode ser desfeita. A questão da reintegração familiar é complexa e possui uma ambivalência que pende entre a família de origem e a substituta. Por um lado, deve-se ficar atento para que o encaminhamento à adoção não seja precipitado. Por outro, a atenção também deve se voltar para não idealizar o retorno à família de origem, inviabilizando a recolocação em família substituta.

For fim este estudo gostaria de estabelecer uma crítica em relação ao procedimento muitas vezes utilizado quando a criança ou o adolescente a ser adotado encontra-se abrigado. Principalmente nos abrigos que recebem bebês em conjunto com crianças mais velhas, existe a prática do casal interessado ir ao abrigo visitar o bebê que está pensando em adotar. Essa é uma prática que deve ser evitada, pois as demais crianças, as que não serão adotadas, lidam muito mal com tal situação, que possui a potencialidade de reatualizar sua vivência do abandono. Vivi uma situação dessas em um dos abrigos em que trabalhei e a experiência foi bastante ambivalente. Por um lado, não se pode deixar de testemunhar a emoção de presenciar o momento mágico em que uma criança ganha uma mãe. Perceber a transformação nos olhos de uma mulher, que chega hesitante e dirige-se para uma criança até então desconhecida e enxerga nela aquele filho que a acompanhará para o resto de sua vida. Para todos os 
funcionários presentes, a sensação de realização pelo trabalho desenvolvido foi imensa, o que não é de se desconsiderar em um ofício em que raramente se consegue ver de modo tão nítido o fruto do esforço profissional.

Como a maioria dos trabalhos na área da educação e assistência social, muitas vezes, não se consegue visualizar de modo imediato o retorno de investimentos pessoais. Por outro lado, a reação das outras crianças abrigadas foi muito sofrida. Algumas chegaram até a reagir agressivamente, dizendo que não iam deixar o casal levar o bebê embora, como se o estivessem protegendo. Diziam que o bebê era agora como um irmão para eles e que, por isso, não poderiam permitir que partisse. Outras, ao contrário, dirigiram ao casal uma simpatia e afetuosidade nitidamente exacerbada, querendo chamar sua atenção a todo custo, como se estivessem dizendo: "leve-me também".

\section{$\underline{\text { 5.1.9 A organização do abrigo como uma residência }}$}

"A relação entre as pessoas e os espaços, especialmente o espaço de moradia, extrapola a estrita utilidade: o significado da habitação para o ser humano vai além da função de simples meio de proteção. Para o indivíduo, a casa simboliza o seu lugar no mundo e é por meio de seu endereço que ele estabelece sua referência no espaço e na própria sociedade." (Organização Panamericana de Saúde, 1999).

As recomendações para reordenamento dos abrigos estabelecem que o atendimento em acolhimento institucional deve ser o mais semelhante possível ao de uma residência comum. Isso significa, por exemplo, que os abrigos não devem possuir placas que os identifiquem (cf. Resolução 053/99 do CMDCA-SP) ${ }^{27}$ e que devem estar instalados em bairros residenciais, em uma edificação que não se distinga das demais casas do bairro, para que não seja estigmatizado. "Os grandes pavilhões, símbolo dos antigos orfanatos, devem ser totalmente abolidos" (IPEA, 2003, p. 11).

\footnotetext{
27 "Qualquer destaque, identificação especial ou emblema oficial são desaconselháveis a fim de preservar a natureza residencial do serviço, evitando-se discriminação em relação às crianças e jovens. Preferencialmente, mesmo os utensílios e veículos do serviço devem ter identificação discreta."
} 
[...] as instituições chamadas "totais", destinadas a crianças e adolescentes em situação de risco - como orfanatos, internatos, asilos e reformatórios materializavam-se em construções muito características: prédios enormes, longos corredores, quartos numerosos que reuniam várias camas, não identidade individualizada dos espaços. Além disso, previam a realização intramuros de quase todas as atividades atinentes à vida das crianças e adolescentes abrigados: consultórios médicos, gabinetes odontológicos, enfermarias, salas de aula, capelas, ginásios esportivos, etc. Em síntese, um ambiente tipicamente institucional voltado à ampla intervenção e "reforma" no modo de ser e viver dos abrigados, uma vez que as instituições tinham como objetivo transformá-los em indivíduos mais adequados às exigências da sociedade da época. (MELLO, 2003, p. 139)

A partir de uma descrição como essa, pode-se perceber que existia uma relação entre a estrutura física e o projeto pedagógico em operação naquelas instituições. O isolamento físico era condição essencial à tarefa correcional, já que a alienação do espaço favorece a alienação simbólica. O que estava em jogo nesses grandes complexos murados não era simplesmente o distanciamento da rua, antigo habitat costumeiro dos meninos e meninas de orfanatos. $\mathrm{Na}$ realidade, a segregação física servia como instrumento que carregava a mensagem simbólica de esquecimento do passado, já que a rua (e os "vícios" a ela associados) era o passado dessas crianças e jovens. O concreto e os tijolos deixavam de ser meros obstáculos, necessários para se evitar as fugas. Tinham também a função de barreira simbólica entre a criança ou o adolescente e sua história de vida pregressa à institucionalização.

Os muros e todo o monumental aparato dos grandes complexos davam as condições concretas para objetivo de "reformar"" aqueles que neles adentravam. A ideia era

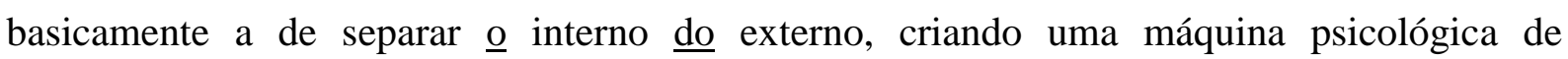
referencial único: a internação alienava a criança ou o adolescente de todas as outras possíveis experiências e influências alheias à instituição.

Assim, crianças e adolescentes afastados de suas famílias e da vida em comunidade eram também ceifados em suas referências ambientais. As grandes dimensões espaciais, a organização impecável, a extrema homogeneidade e a rotina rígida mostravam que ali não estavam em casa. (MELLO 2003, p. 140)

\footnotetext{
${ }^{28}$ Um exemplo desse objetivo "reformador" pode ser extraído do livro de Lima (1942) sobre o Patronato de Menores: "A finalidade do Patronato de Menores é receber o menor em abandono, ou em risco de perversão ou já viciado e, transcorrido o período educacional, restituir à sociedade um cidadão sadio de corpo e alma, apto para constituir uma célula do organismo social, capaz de prever à própria subsistência e de impulsionar a vida econômica nacional" (LIMA, 1942, p. 9).
} 
A presença de escolas, bem como de assistência médica no interior dos internatos, além de ser mais um elemento segregador, já que a criança ou o adolescente não precisava sair da instituição para quase nenhuma atividade, revela também a indiferenciação que existia em relação às atribuições dessas instituições, que misturavam serviços das áreas da saúde, educação e assistência social.

Com as inovações trazidas pelo ECA, o foco dos trabalhos das instituições de abrigo deixa de ser a correção de certos desvios individuais e passa a ser a proteção daqueles que são, em última análise, vítimas do social. O interesse a ser considerado não é mais o de uma sociedade assustada com o perigo que os "desajustados" representam, mas sim as necessidades desses que estão em risco pessoal e social. O objetivo deixa de ser "proteger a sociedade" e passa a ser proteger as crianças e os adolescentes.

E, obviamente, que, dentre essas necessidades, está a de viver em um ambiente que seja o menos agressivo possível. Quando esse ambiente não pode ser a própria residência, deve, ao menos, se assemelhar a ela.

É preciso que as crianças e adolescentes em situação de abrigo sintam-se em casa ou, pelo menos, em uma casa, como acontece com a maioria das crianças e dos adolescentes da comunidade que conhecem e que os circunda. (MELLO, 2003, p. 141)

Sendo assim, com um olhar imbuído desses novos referenciais, é possível diagnosticar uma parte das características institucionais de um abrigo a partir de sua estrutura arquitetônica. Como exemplo, podemos citar que, na cidade de São Paulo, dos abrigos

[...] com aparência de "prédio escolar", com três ou mais pavimentos, 77\% tiveram sua fundação no período anterior à promulgação do ECA. Possivelmente, a filosofia dessas instituições era fundamentada nos internatos preconizados pelos Códigos de Menores anteriores ao Estatuto, os quais atendiam elevado número de crianças e adolescentes no mesmo espaço. (AASPTJ-SP/NCA-PUCSP/SAS/FUNDAÇÃO ORSA, 2003, p. 79)

Assim, para analisar se as instalações físicas dos abrigos estão adequadas às exigências da nova legislação, as análises terão início, novamente, a partir da pesquisa do IPEA (2003), que verificou os seguintes aspectos: a) se possuem espaços individuais para que crianças e adolescentes possam guardar seus pertences pessoais ${ }^{29}$; b) se possuem, no máximo, seis dormitórios; c) se apresentam características externas residenciais; d) se não possuem

\footnotetext{
${ }^{29} \mathrm{O}$ art. 17 do ECA estabelece o direito ao respeito como direito fundamental de crianças e adolescentes, o que inclui, entre outras coisas, a preservação de seus espaços e objetos pessoais.
} 
áreas exclusivas para atendimentos especializados, tais como consultórios médicos ou odontológicos, salas de aula ou de oficinas profissionalizantes, já que o ideal é que esses recursos sejam buscados na rede de serviços da comunidade; e e) se mantêm, no máximo, quatro crianças e adolescentes por dormitório.

O resultado da pesquisa é que apenas $17,5 \%$ dos abrigos são adequados, segundo todos os critérios avaliados (IPEA, 2003, p. 12), mostrando o quanto o fantasma dos antigos orfanatos ainda expressa sua herança na arquitetura dos abrigos.

Além dessa avaliação pontual, os critérios construídos pela equipe de pesquisa do Levantamento Nacional são importantes, pois podem se tornar parâmetros para os gestores públicos e privados adequarem os abrigos pelos quais são responsáveis. Pode-se contribuir para esse quadro e acrescentar mais os seguintes indicativos: a) além de espaços onde possam guardar pertences pessoais, é importante que cada criança e adolescente abrigado possua roupas de uso exclusivo; b) evitar cozinhas e lavanderias industriais, pois estas são inacessíveis às crianças e aos adolescentes. O ideal é que eles possam participar de alguma maneira do preparo dos alimentos, bem como da lavagem das roupas, sempre respeitando as capacidades e os limites do desenvolvimento, pois essas são atividades importantes para a construção de sua autonomia; c) possuir espaços para recreação ao ar livre, tal como um quintal ou jardim. Quadras dentro dos abrigos devem ser evitadas para incentivar a participação dos abrigados nos espaços comunitários de esporte e lazer. Esse é um preconceito presente na mentalidade de muitos gestores públicos, principalmente das grandes cidades, que, baseados em seu desconhecimento da questão, acham que estão defendendo os interesses das crianças e dos adolescentes, transformando o abrigo em um clube! d) possuir espaços com brinquedos e livros, que devem ficar guardados em locais acessíveis aos usuários; e) possuir um espaço para estudo e realização das tarefas escolares. O ideal é que fique em um lugar silencioso da casa e, se possível, até mesmo um tanto isolado (mas não separado), para que se evitem distrações; f) possuir espelhos em altura adequada para que todos possam ver sua própria imagem. O reflexo no espelho é um fator facilitador na constituição e na elaboração da autoimagem corporal (especialmente em uma fase de mudanças físicas tão intensas como a infância e, principalmente, a adolescência) e, em consequência, da própria identidade; g) as áreas destinadas à equipe administrativa ou técnica não devem ocupar grandes espaços ou áreas centrais da casa. Quando possível, o ideal é que essas equipes possam ser alojadas em uma área diversa da de moradia das crianças e adolescentes, diminuindo o aspecto institucional dessas últimas. 
Além desses, a pesquisa realizada em São Paulo pela AASPTJ-SP/NCAPUCSP/SAS/Fundação Orsa (2003) reforça a importância dos abrigos destinarem seu espaço exclusivamente à atividade de abrigo (cf. p. 80), pois ainda é comum encontrarmos instituições que dividem o espaço no qual desenvolvem o serviço de abrigo com outras atividades tais como creches, clínicas, centros de juventude e, especialmente, atividades assistenciais, o que prejudica a necessária característica residencial dos serviços de acolhimento.

Outro ponto fundamental na avaliação da semelhança residencial é o atendimento em pequenos grupos, previsto pelo ECA (art. 92, inc. III).

Estudos sobre o atendimento massificado a crianças e adolescentes realizado nas grandes instituições de abrigo, que recebem grandes números de abrigados, têm revelado os custos que tal situação acarreta para essas crianças e adolescentes: carência afetiva, dificuldade para o estabelecimento de vínculos, baixa auto-estima, atrasos no desenvolvimento psicomotor e pouca familiaridade com rotinas familiares. (IPEA, 2003, p. 11)

$\mathrm{O}$ atendimento massificado transforma questões individuais em coletivas, ou seja, a instituição perde a particularidade de cada criança e adolescente, passando a atender um abrigado abstrato, forjado na ficção de uma espécie de "média" de todos os seus atendidos.

Apesar da falta de uma regulamentação oficial para a questão, já existem alguns apontamentos indicando que o número de 20 a 25 crianças e adolescentes por abrigo seria o recomendável. ${ }^{30} \mathrm{O}$ próprio Levantamento Nacional indica que, embora "o Estatuto não estabeleça um número exato para esse atendimento em pequenos grupos, as diretrizes de reordenamento indicam um máximo de 20 a 25 por unidade de atendimento" (IPEA, 2003, p. 12).

Nesse ponto, a maioria dos abrigos pesquisados $(57,6 \%)$ atende até 25 crianças e adolescentes (IPEA, 2003, p. 12). No entanto, este estudo ainda considera 25 abrigados por unidade de atendimento um número bastante elevado. Afinal, se o parâmetro é a residência comum, cabe uma pergunta simples: qual residência possui 25 pessoas morando nela? É claro que o avanço em relação aos grandes complexos é enorme. Contudo, não se pode furtar-se de estipular aquilo que se considera o ideal, sob pena de nunca conseguir atingi-lo. Pensa-se que o parâmetro de uma família grande, entre 8 e 10 pessoas, poderia funcionar como modelo para o número de abrigados por unidade.

\footnotetext{
${ }^{30}$ A Resolução 053/99 do CMDCA/SP estipula que os abrigos devem atender a, no máximo, 20 crianças e adolescentes. Já o CMDCA/RJ aceita abrigos atendendo grupos de até 25 crianças e adolescentes.
} 
Outro indicador do cuidado em pequenos grupos é o número de educadores/monitores por criança e adolescente atendido. Considerou-se como adequado um grupo de 12 abrigados por profissional responsável. O resultado aqui foi que $74,2 \%$ dos abrigos correspondem a esse critério (cf. IPEA, 2003, p. 12)

Nesse ponto, também é preciso ponderar se 12 abrigados por profissional não é número um tanto elevado. Em uma instituição com 24 crianças e adolescentes seriam necessários dois educadores. Se um deles tiver que sair para levar uma criança ao médico, por exemplo (o que não é raro), apenas uma pessoa terá que cuidar de 23 crianças e adolescentes. Como é possível garantir atenção individualizada sendo responsável por 23 crianças e adolescentes?

Com um critério de avaliação tão elevado, o Levantamento Nacional acaba por não indicar algo que aparece com frequência nas falas dos próprios profissionais dos abrigos, como apontado no item especialmente dedicado a esses: a falta de profissionais. Tomando-se por base simplesmente a pesquisa do IPEA (2003) tem-se a sensação de que a quantidade de profissionais trabalhando nos abrigos atualmente é adequada na grande maioria deles, fato que a experiência deste trabalho não tem confirmado.

Quanto a essa questão, a NOB-RH/SUAS (2006) é um pouco mais exigente, colocando um mínimo de 1 profissional para cada 10 abrigados, com ressalva de que, caso haja atendidos com necessidades de atenção específicas (deficientes, com necessidades específicas de saúde, soropositivas, com idade inferior a um ano etc.), esse número deverá ser ainda menor.

É um pequeno avanço, mas o presente estudo ainda considera que a argumentação desenvolvida anteriormente para criticar o número de 12 atendidos por profissional vale também para a proposta de 10 .

Outro ponto a favor da argumentação deste trabalho é a discrepância da porcentagem na avaliação do atendimento em pequenos grupos: juntando os dois indicadores pesquisados, tem-se um total de 48,2\% dos abrigos em situação adequada (cf. IPEA, 2003, p. 12). É uma taxa que salta aos olhos quando se acompanha os demais índices levantados. Será que essa elevada e destoante porcentagem indicaria um aspecto do atendimento dos abrigos que estaria mais de acordo com as normas propostas ou uma escolha equivocada dos critérios de avaliação da pesquisa?

Outro fator relevante que também se deve destacar para a análise da qualidade dos serviços prestados é a própria localização dos abrigos, principalmente no que se refere à inserção da edificação no contexto da comunidade. Mello (2003, p. 151) propõe três quesitos 
para a avaliação dessa questão: a existência de outras residências nas proximidades do abrigo; o aspecto externo da edificação (casa, apartamento, pavilhões/prédios ou outros); e a disponibilidade de serviços da vizinhança.

Em relação ao primeiro quesito, a quase totalidade dos abrigos está adequada $(95,1 \%)$ (MELLO, 2003, p. 151). No entanto, em relação ao segundo, o índice baixa para 66,9\%, sendo que foram considerados adequados aqueles abrigos que responderam possuir pelo menos uma edificação do tipo casa (MELLO, 2003, p. 153). Em relação ao terceiro quesito, a pesquisa mostrou que

[...] 84,6\% dos abrigos pesquisados possuem escolas próximas e 82,7\% têm acesso facilitado a pontos de ônibus. Comércio e igrejas/templos estão presentes na vizinhança de $73,3 \%$ das instituições, enquanto há postos de saúde em $66,2 \%$ dos casos. Cerca de um terço dos abrigos mantém proximidade com equipamentos de hospital $(34,5 \%)$, escritórios $(28 \%)$ e delegacias $(27,3 \%)$. São minoria as entidades que têm como vizinhas outras instituições de abrigo (21,1\%) e indústrias (16,8\%). (MELLO, 2003, p. 154)

O quadro apresentado mostra que, de maneira geral, as instituições pesquisadas pelo Levantamento Nacional têm um bom acesso aos serviços e equipamentos mais importantes, apesar de 66,2\% dos abrigos próximos a UBSs ser ainda um índice um tanto reduzido. O índice de 34,5\% de abrigos próximos a hospitais não é tão preocupante, já que esses equipamentos são, de fato, serviços centralizados, ou seja, podem ser distantes da maioria das pessoas porque atendem queixas mais complexas e menos frequentes. Como apontado, preocupa o fato de $33,8 \%$ dos abrigos serem distantes daquelas instituições que são a porta de entrada do sistema de saúde, ou seja, são pensadas justamente para estarem distribuídas no território, próximas das pessoas e dos responsáveis pelos atendimentos de menor complexidade e dos de caráter preventivo. De maneira geral, tais dados revelam uma deficiência no sistema de saúde, especialmente em seu sistema de proteção básica.

Os três quesitos propostos, quando analisados em conjunto, somam um total de 58,4\% de abrigos adequados (MELLO, 2003, p. 157 ). Esse índice nos indica que, no que se refere ao aspecto residencial dos abrigos, os maiores desafios que ainda estão por serem superados se encontram menos nos parâmetros externos dessas instituições do que na ambientação interna de suas edificações. O principal problema se encontra da porta para dentro, onde ninguém vê. 


\subsection{A demanda das instituições de acolhimento}

Uma vez concluída a análise dirigida às instituições que executam a política pública de abrigamento, passar-se-á em seguida, ao estudo das pessoas às quais ela visa beneficiar.

\section{$\underline{\text { 5.2.1 As crianças e adolescentes abrigadas }}{ }^{31}$}

Iniciar-se-á a análise pelas próprias crianças e adolescentes.

5.2.1.1 O perfil de quem vive nos abrigos: o rosto das vítimas da violência contra crianças e adolescentes

Os abrigos pesquisados pelo Levantamento Nacional acolhiam, na época da pesquisa, cerca de 20 mil crianças e adolescentes ${ }^{32}$. A maioria deles são meninos (58,5\%), negros $(63,6 \%)$ e têm entre 7 e 15 anos (61,3\%) (IPEA, 2003, p. 4).

Em São Paulo, a pesquisa da AASPTJ-SP/NCA-PUCSP/SAS/Fundação Orsa (2003) constatou 4.847 abrigados nas instituições paulistanas. Os dados confirmam as indicações da pesquisa nacional: $57 \%$ são meninos (p. 165), 52\% são negros (p. 167), com uma faixa de concentração etária de 6 a 16 anos (p. 171). ${ }^{33}$

"Os bebês e as crianças com pouca idade são minoria nos abrigos" (AASPTJSP/NCA-PUCSP/SAS/FUNDAÇÃO ORSA, 2003, p. 213), pelo menos nas instituições paulistanas. Tal fato está intimamente relacionado com os preconceitos etários dos

\footnotetext{
${ }^{31}$ Vale destacar a preferência deste estudo pelas expressões "crianças e adolescentes abrigados" ou "crianças e adolescentes em medida de abrigamento" do que pelo termo "abrigados". As primeiras nos remetem à ideia de que se trata de crianças e adolescentes comuns que estão momentaneamente passando por uma medida de proteção específica, que é o abrigo. Simplesmente o termo "abrigados" dá a impressão de que todos os aspectos da vida dessas crianças e adolescentes poderiam ser resumidos ao abrigo, assumindo, portanto, um tom reducionista. Por isso, sempre que possível, optamos pela utilização das primeiras expressões, deixando o segundo somente para quando a reiterada utilização das primeiras comprometeria a estilística do texto.

${ }^{32}$ Vale lembrar que esse não é o número total de abrigados no país, uma vez que o Levantamento Nacional não pesquisou todos os abrigos do Brasil.

${ }^{33}$ Como as faixas etárias utilizadas nas referidas pesquisas foram ligeiramente diferentes, empreendeu-se as análises tomando como base o dado do Levantamento Nacional.
} 
pretendentes à adoção, ou seja, como os bebês e as crianças com pouca idade são os preferidos pelos adotantes, sua presença nos abrigos é bastante reduzida em termos numéricos, já que passam pouco tempo nas entidades de acolhimento até serem encaminhados para uma família substituta.

Com base nessas informações pode-se visualizar algo muito importante para a elaboração de políticas públicas: um perfil de vulnerabilidade. Tal perfil permite dirigir a atenção e as ações da política para aqueles que mais necessitam dela, elencando prioridades, inclusive na distribuição dos recursos.

Caberia perguntar o porquê desse perfil. A questão do negro parece ser um pouco mais óbvia, embora não menos complexa, já que se sabe do preconceito e da discriminação raciais a que essa parcela da população está submetida. Nesse sentido, "uma das razões que levam crianças negras a permanecerem mais tempo no abrigo relaciona-se à dificuldade de serem encaminhadas à família adotiva, mesmo quando se trata do seu próprio grupo racial" (AASPTJ-SP/NCA-PUCSP/SAS/FUNDAÇÃO ORSA, 2003, p. 167), conforme apontam pesquisas como a de Silveira (2002). Por ser a questão racial demasiadamente ampla para os objetivos desta pesquisa, este estudo optará por não tratar desse tema, remetendo o leitor à literatura especializada, como a citada anteriormente.

Contudo, mesmo dentro das limitações deste trabalho, pode-se iniciar um debate em torno das demais características do perfil: por que meninos? E por que entre 7 e 15 anos? Se existem mais meninos nos abrigos, poder-se-ia dizer que as meninas sofrem menos violência? Este estudo considera que não. No entanto, considera ser possível afirmar que sofrem violências diferentes. A partir dos dados apresentados no PNCFC (2006, p. 59) é possível perceber que os tipos de violência não se distribuem igualmente entre os sexos, de modo que, enquanto os meninos são mais vítimas de violência física (agressões, espancamentos etc.) do que as meninas; ocorre o inverso em relação à violência sexual, por exemplo. E sabe-se do pacto de silêncio que costuma ser erigido em torno das violências sexuais, considerada por muitos como uma patologia, enquanto que as violências físicas, ao contrário, não encontram uma repressão social tão forte. $\mathrm{Na}$ verdade, são muitas vezes amplamente divulgadas pelos próprios agressores, que julgam estar oferecendo aos pequeninos uma "boa" educação. Talvez o emudecimento que paira sobre a violência sexual e o alarde em torno da física, faz com que essa última seja mais denunciada e, consequentemente, suas maiores vítimas, os meninos, sejam mais frequentemente encaminhados aos abrigos.

Além disso, a experiência profissional do autor tem revelado que a menina costuma ser mais bem aceita na casa de sua família extensa (tios, avós etc.). Isso muitas vezes 
consegue evitar o abrigamento ou, quando isso é inviável, pode, no entanto, facilitar o desabrigamento. A hipótese deste pesquisador é que as meninas são mais acolhidas entre os membros de sua própria família porque logo se vislumbra sua captura para os serviços domésticos. No ideário popular, a menina "vem para ajudar", enquanto o menino, quando ainda não está em idade de trabalhar, é apenas "mais uma boca para alimentar".

A questão etária também é intrigante. Novamente aqui, também não se acredita que uma determinada faixa de idade seja mais ou menos vítima de violência. Considera-se que, conforme a criança cresce, ela se torna cada vez mais capaz de denunciar as violências que sofre e, assim, acionar os órgãos de proteção, direta ou indiretamente. Contudo, se assim fosse, o número de abrigados deveria aumentar em correspondência ao crescimento da idade, ou seja, o número de abrigados não deveria diminuir a partir dos 16 anos. Nesse caso, o trabalho com essa demanda leva a crer que, a partir de determinada idade - que gira em torno dos 15 anos, mas que, obviamente, pode apresentar variações individuais -, a adesão desse público ao abrigo cai porque aumenta o seu interesse pela rua. Por volta dessa faixa etária, a fase áurea da adolescência, esses meninos e meninas já acumulam certa dose de autonomia e também um imenso questionamento da autoridade que o abrigo inevitavelmente representa, de tal modo que os próprios serviços de proteção desenvolvem grandes dificuldades para lidar com as questões dos adolescentes e acabam por "empurrá-los" para a rua.

$\mathrm{Na}$ vida caótica que muitos desses meninos e meninas possuem, é crucial reconhecer que as instituições de abrigamento provavelmente desempenham na dinâmica psíquica de muitos deles a função de figura paterna: de um lado, provendo proteção e, de outro, como representante social das regras e dos limites. Para esses jovens que circulam entre as ruas, suas famílias e os serviços de internação, quando o pai está concretamente ausente de suas histórias de vida, a autoridade a ser questionada em seu processo de constituição de identidade poderá ser uma instituição que o represente.

Seguindo a lógica iniciada no parágrafo anterior, na falta de figuras familiares que encarnem as funções paternas e maternas, muito provavelmente pela ausência ou mesmo instabilidade e itinerância dessas figuras, se o abrigo é um grande candidato a assumir o papel de pai, pode-se pensar na própria rua como representação da figura materna, na medida em que esta se configura como um ambiente acolhedor daqueles que o restante da sociedade rejeita. Apesar das dificuldades que existem nela, a rua nunca diz "não" a ninguém.

Tais apontamentos parecem ser corroborados pelo dado de que, na cidade de São Paulo, por exemplo, “constatou-se um predomínio de crianças (61\%) sobre adolescentes (38\%) (AASPTJ-SP/NCA-PUCSP/SAS/FUNDAÇÃO ORSA, 2003, p. 168). A pesquisa de 
Fávero, Vitale e Baptista (2008) aponta a mesma tendência, mas com uma porcentagem ainda maior de crianças $(71 \%)$ em relação aos adolescentes (24\%) (p. 28). As reflexões anteriormente propostas a respeito dos questionamentos do adolescente em relação à proteção oferecida pelo abrigo remetem a perguntar se essas instituições estão de fato preparadas para acolhê-los, pois tem-se que reconhecer que as metodologias de trabalho com crianças e adolescentes são bem diferentes.

Além disso, será que as entidades de acolhimento estão preparadas para superar o fato de que a própria sociedade não vê o adolescente como uma pessoa que necessite de proteção, ou seja, de que o conceito socialmente aceito de proteção exclui os adolescentes?

Outro dado curioso da pesquisa nacional acerca da relação entre o número de meninos e meninas abrigadas é que a diferença entre eles cresce conforme a faixa etária aumenta (IPEA, 2003, p. 5), ou seja, quanto mais velhos, mais meninos são abrigados em relação às meninas. Isso nos indica que, conforme vão ficando mais velhos, os meninos se tornam ainda mais vulneráveis em termos sociais. O mesmo fenômeno ocorre em relação aos negros que, conforme crescem, se tornam ainda mais sujeitos às situações de risco do que os brancos. Por que isso ocorre?

A pesquisa na cidade de São Paulo revelou mais um importante dado a respeito da população abrigada: a maioria (73\%) nasceu na própria metrópole paulistana (cf. AASPTJSP/NCA-PUCSP/SAS/FUNDAÇÃO ORSA, 2003, p. 164), indicando que o perfil de migrante não é uma característica da maior parte dos abrigados. No entanto, essa situação se inverte quando trata dos pais dessas crianças e adolescentes, uma vez que a maioria deles é proveniente de outros estados (cf. AASPTJ-SP/NCA-PUCSP/SAS/FUNDAÇÃO ORSA, 2003, p. 174), ou seja, em sua maioria são os filhos dos migrantes que estão nos abrigos da cidade de São Paulo.

A migração de pessoas das classes populares normalmente traz consigo fenômenos como o desenraizamento social, ou seja, a sensação de não pertencimento devido à segregação pela qual o migrante passa. $\mathrm{O}$ desenraizamento contribui para o processo de isolamento social, característico das famílias de crianças e adolescentes abrigados (tema que será aprofundado posteriormente), minando as bases de uma convivência comunitária e familiar mais saudável.

No que se refere ao vínculo com o sistema de ensino, nota-se que a imensa maioria deles $(97,1 \%)$ vai à escola. No entanto, entre os adolescentes de 15 a 18 anos, o índice de analfabetos é alto: 19,2\% (cf. IPEA, 2003, p. 4). Tais dados indicam que o acesso à rede escolar não é um problema que aflige esses meninos e meninas. O problema é a qualidade do ensino que lhes está sendo oferecido. 
A pesquisa na cidade de São Paulo constatou que $75 \%$ dos abrigados cursam o ensino fundamental e apenas $5 \%$ estão no ensino médio (cf. AASPTJ-SP/NCAPUCSP/SAS/FUNDAÇÃO ORSA, 2003, p. 172), incorporando ao perfil de vulnerabilidade dessa população outra importante característica: a defasagem série/idade. A partir desse diagnóstico, fica claro que o abrigo deve articular-se com a rede de ensino para viabilizar a oferta de programas intensivos de reforço escolar. De fato, muitas crianças e adolescentes, quando entram no abrigo, já se encontram atrasadas na escola. Daí o esforço da instituição de acolhimento para reverter esse processo, sempre em parceria com a escola. A relação entre abrigo e escola não costuma ser sempre harmoniosa, no entanto, se essas duas instituições não trabalharem em conjunto, com o objetivo comum de assegurar os direitos das crianças e adolescentes das quais ambas são responsáveis, se estará condenando esses meninos e meninas excluídos a novas formas de exclusão.

O cruzamento de dados entre a escolaridade e a faixa etária revelou uma defasagem ainda maior entre os adolescentes. Dentre aqueles com idade entre 15 e 18 anos apenas 20\% cursam o ensino médio (cf. AASPTJ-SP/NCA-PUCSP/SAS/FUNDAÇÃO ORSA, 2003, p. 173), "o que pode significar ainda maior dificuldade no processo de desligamento e autosustente para aqueles que não têm retaguarda familiar" (cf. AASPTJ-SP/NCAPUCSP/SAS/FUNDAÇÃO ORSA, 2003, p. 172).

Além disso, essas informações colocam uma especificidade para se pensar em programas de primeiro emprego para essa população. Esses projetos devem incluir trabalhos que possam ser ocupados por pessoas com baixa qualificação profissional. Essa afirmação advém do fato de que se sabe da importância que o trabalho pode ter na vida desses jovens, inclusive como fator motivador para a continuidade dos estudos e para o aumento do grau de escolaridade. Sabe-se, também, que muitos dos programas de primeiro emprego costumam ser excludentes dessa população com baixa qualificação.

Para muitos desses adolescentes, a escola só passa a ser valorizada a partir da experiência do trabalho, ou seja, são as necessidades inerentes a um determinado ofício que permitem a ressignificação do valor da escolarização. É preciso lembrar que a maioria desses jovens é oriunda das classes mais empobrecidas da sociedade, para as quais a questão da sobrevivência mais imediata se impõe quase sempre como a principal prioridade a ser perseguida. Tal mecanismo perverso acaba por deixar os investimentos familiares na escolarização e mesmo o próprio sentido e valor dos estudos em segundo plano.

A relação com o sistema de ensino precisa ser planejada, inclusive quando a instituição de acolhimento realiza um desabrigamento. Como a maioria das redes de abrigos 
ainda não se encontra regionalizada, quando uma criança ou adolescente é abrigado, ele normalmente tem que trocar de escola, o que por si só já caracteriza uma revitimização. $\mathrm{O}$ mesmo acontece quando do seu desabrigamento, de modo que, quando for possível, este deve preferencialmente ocorrer em confluência com os períodos letivos, para se evitar que a criança ou o adolescente tenha que, além de sua adaptação à família, também se adaptar a uma nova escola, no meio de um ciclo de ensino.

Revelou-se também que $86,7 \%$ dos abrigados possuem família e que 58,2\% destes mantêm vínculos familiares, sendo que apenas 5,8\% estão impedidos judicialmente de terem contatos com os familiares (cf. IPEA, 2003, p. 4). Na cidade de São Paulo, esse índice é de $67 \%$ (cf. AASPTJ-SP/NCA-PUCSP/SAS/FUNDAÇÃO ORSA, 2003, p. 131), o que nos aponta um estado um pouco mais avançado da política de acolhimento institucional em São Paulo quando comparado com o dado nacional. Isso porque quanto melhor for o trabalho de reintegração familiar da rede de abrigos de uma determinada localidade, menor será a taxa de abrigados com família.

"Essas crianças e adolescentes vivem, portanto, a paradoxal situação de estar juridicamente vinculados a uma família que, na prática, já há algum tempo, não exerce a responsabilidade de cuidar deles" (PNCFC, 2006, p. 62).

No entanto, este estudo considera que, se há família e há vínculo, nada justifica a institucionalização por um período prolongado, pois, havendo vínculo, existe possibilidade de trabalho para reintegração familiar. Esses dados apontam para o despreparo das entidades de abrigamento na realização de uma tarefa que lhes é essencial e prioritária: a reintegração familiar e a consequente defesa do direito à convivência familiar, garantido na Constituição e reiterado pelo ECA. Tal levantamento mostra, na realidade, talvez um dos maiores problemas do sistema de abrigamento no Brasil. As crianças e os adolescentes entram com muito mais facilidade do que saem, constituindo um modelo em forma de funil, quando o ideal deveria ser justamente o oposto.

Além disso, o fato de a grande maioria dos abrigados possuir família fornece base para desconstruir um importante mito presente no senso comum e que paira sobre os abrigados: o de que todos eles são órfãos. O abrigo, talvez ainda carregando a simbologia dos antigos orfanatos, ainda é costumeiramente visto como um "lugar de órfãos". Tal situação é importante de ser salientada e trabalhada com a equipe do abrigo, que deve estar preparada para lidar com isso no cotidiano de sua prática, pois não foram poucas as vezes em que o autor deste trabalho atendeu crianças que disseram: "Tio, lá na escola ficam dizendo que eu não tenho mãe!’. 
Se, para o senso comum adulto, o órfão é motivo de pena, para as crianças, "órfão" parece se transformar em um xingamento. Nessa concepção pejorativa, ser órfão é não ser amado por ninguém, não pertencer, não possuir quem o proteja e o defenda. Mesmo não sendo órfãos em sua imensa maioria, são com esses preconceitos que as crianças e os adolescentes abrigados terão que lidar em praticamente todos os seus espaços de interação social. Serão vistos como párias, como seres diferentes, seres aos quais falta algo de muito fundamental. Seres, portanto, inferiores, menores, cidadãos de segunda categoria. Serão excluídos. Serão tratados como se fossem responsáveis pelo seu próprio abandono, sendo culpabilizados com perguntas como: o que ele fez para ter sido largado? Ou o que será que ele tem para ninguém gostar dele? De abandonado, será tratado como abandonável. O abrigado, tal como todo excluído, será incômodo porque ele carrega a insígnia do nosso fracasso enquanto sociedade. Serão vistos como os frutos malditos de nosso ventre, mas são, na verdade, simplesmente os filhos que não se quer cuidar.

De modo mais específico, a criança ou o adolescente abandonado carrega consigo uma estranha prova de que o amor parental não é algo dado naturalmente, fato que costuma nos dar ojeriza.

\subsubsection{Os motivos de abrigamento: a excepcionalidade em questão}

A investigação acerca dos motivos que levam ao abrigamento revela outro flagrante de desrespeito ao ECA, já que o Levantamento Nacional aponta que a pobreza é o motivo mais citado $(24,2 \%)$ (cf. IPEA, 2003, p. 4).

Para além do fato das categorias de violência serem bastante confusas e carentes de uma conceitualização mais consistente, o fato da pobreza ser destacada como principal motivo de abrigamento contraria o Estatuto ${ }^{34}$, já que este "estabelece a obrigatoriedade de inclusão da família em programas oficiais de auxílio quando pais ou responsáveis não conseguem cumprir com suas obrigações de proteção aos filhos por motivos de carência material” (IPEA, 2003, p. $4)$.

\footnotetext{
${ }^{34}$ Art. 23. A falta ou carência de recursos materiais não constitui motivo suficiente para a perda ou suspensão do pátrio poder. Parágrafo único: Não existindo outro motivo que por si só autorize a decretação da medida, a criança ou adolescente será mantido em sua família de origem, a qual deverá obrigatoriamente ser incluída em programas oficiais de auxílio (ECA, 1990).
} 
A proibição do abrigamento por pobreza é o principal avanço jurídico do ECA no que se refere ao combate à institucionalização de crianças e adolescentes no Brasil. Contrariando uma tendência histórica, o Estatuto obriga a sociedade a não mais esconder a infância e juventude pobres atrás de muros. Nenhuma família pode ser desfeita pelo simples fato de ser pobre ou porque a sociedade rica não quer enxergar que existe pobreza.

Para haver abrigamento, é preciso que haja violência. É claro que a pobreza em si mesma pode ser considerada uma violência: uma violência da sociedade em geral contra o pobre. Mas é uma violência que não justifica outra violência: a do próprio abrigamento. $\mathrm{Na}$ realidade, abrigar, na medida em que é separar uma família, é sempre um ato violento. Mas é uma violência necessária em alguns casos. É por isso que, mesmo quando ela é necessária, deve ser excepcional e provisória. O abrigamento é, na verdade, um "cálculo de violências".

Em entrevistas junto aos dirigentes das entidades pesquisadas, 35,5\% deles se referem à pobreza como principal dificuldade para o retorno de crianças e adolescentes abrigados para suas famílias (cf. IPEA, 2003, p. 4). Em outras palavras, os motivos que levam ao abrigamento se perpetuam como dificuldades para a reintegração familiar.

Isso indica que as políticas de atenção às crianças e adolescentes não estão devidamente articuladas com ações de atenção às suas famílias, o que poderia não apenas evitar a institucionalização, como também abreviá-la, quando se mostrar excepcionalmente necessária. (IPEA, 2003, p. 4)

A proteção social básica ainda não está conseguindo exercer plenamente seu papel de prevenção, ou seja, de impedir que os casos cheguem até a proteção social especial.

Ainda, abrigar por pobreza indica que o princípio da excepcionalidade (art. 101, parágrafo único do ECA) não está sendo concretizado. Não desabrigar por pobreza revela que é o princípio da provisoriedade que não está sendo seguido. Em situações de pobreza, a legislação atual obriga a inclusão do núcleo familiar em programas de apoio que atuem no sentido da superação das dificuldades encontradas e, inclusive, na prevenção de situações de vulnerabilidade mais graves, como é o caso da violência intrafamiliar.

O ECA estabelece uma lógica nas medidas de proteção que precisa ser seguida. A internação em instituição já não é mais a única opção criada pelo Poder Público para intervir em situações de vulnerabilidade social. A lógica implícita no artigo 101 do Estatuto quer garantir que cada caso será atendido em sua particularidade, ou seja, impõe que o Poder Público disponha de uma ampla e variada gama de opções de ajuda e apoio. A proteção 
disponibilizada pelo Estado deve superar o paradigma da resposta única e padronizada para os problemas sociais que se apresentam de forma diversa.

Quando falamos em excepcionalidade da medida de abrigamento, estamos querendo dizer que o abrigo deve sempre ser a última opção a ser cogitada na solução de caso. Desse modo, abrigar tendo a pobreza como motivação é meramente punir o pobre com a desintegração de sua família pelo simples fato de ser pobre.

Assim, além das políticas básicas de apoio à família não estarem funcionando a contento, quando se fala do não cumprimento do caráter excepcional da medida de abrigo, fala-se das questões que envolvem os motivos de abrigamento e, consequentemente, coloca-se em cheque o trabalho dos principais órgãos abrigadores: o Conselho Tutelar e a Vara da Infância e Juventude que, segundo o PNCFC (2006), têm utilizado "uma aplicação indiscriminada da medida de abrigo" (p. 63).

Levantamento realizado pela Corregedoria-Geral da Justiça nas Varas da Infância e Juventude de São Paulo mostrou que em $26 \%$ das situações em que foi determinado o abrigamento, deveria ter sido aplicada a medida protetiva de apoio sociofamiliar (cf. SÃO PAULO, 2003).

Na cidade de São Paulo, por exemplo, "a maioria das crianças e adolescentes teve seu abrigamento intermediado pela instituição judiciária (55\%). Em 11\%, a medida se deu por meio do Conselho Tutelar" (AASPTJ-SP/NCA-PUCSP/SAS/FUNDAÇÃO ORSA, 2003, p. 182). A partir desses números, se os motivos de abrigamento estão equivocados, deve-se responsabilizar mais o Judiciário do que o Conselho Tutelar. Fica patente a necessidade de aperfeiçoamento e capacitação não só das equipes técnicas do Judiciário, mas também dos próprios juízes das Varas da Infância e Juventude. ${ }^{35}$

Depois do abrigamento por pobreza, o Levantamento Nacional aponta os seguintes motivos de encaminhamento ao abrigo: abandono (18,9\%), violência doméstica $(11,7 \%)$, dependência química dos pais, incluindo alcoolismo (11,4\%), vivência de rua $(7,0 \%)$ e orfandade (5,2\%) (cf. IPEA, 2003, p. 4).

A pesquisa na cidade de São Paulo tendeu a corroborar a hierarquia dos motivos de abrigamento, mas o fez com maiores detalhes, de modo que centrar-se-á os comentários deste estudo nos dados apresentados por esta última.

\footnotetext{
${ }^{35}$ Na realidade, pesquisas como a de Sadek e Arantes (1994) apontam a necessidade primeira de se conhecer o Judiciário, pois, de acordo com levantamentos bibliográficos feitos nas ciências humanas, demonstra-se a existência de poucos estudos teóricos sobre os problemas dessa instituição que, dentre os três poderes da República, talvez seja o menos estudado.
} 
No caso de São Paulo, o abandono e a negligência ${ }^{36}$ são os motivos que se destacam no quadro de encaminhamentos para os abrigos $(22,3 \%)$, seguidos de problemas relacionados à saúde e às condições sociais $(18,8 \%)$. Vale a pena destacar que, apesar da pobreza não mais figurar como principal motivo de abrigamento, o que pode caracterizar um avanço da política de acolhimento institucional na cidade, ela aparece em segundo lugar. São "problemas relacionados à falta de políticas sociais que dêem conta da demanda dos problemas populacionais relativos à saúde, à falta de condições financeiras, de trabalho, moradia e, ainda, à miserabilidade" (AASPTJ-SP/NCA-PUCSP/SAS/FUNDAÇÃO ORSA, 2003, p. 184).

Problemas relacionados à "falta de políticas sociais" não podem mais serem aceitos. Nesse ponto, o Ministério Público tem um papel fundamental para entrar com ações contra o Executivo e dele cobrar respostas.

Apesar do pequeno avanço percebido, a própria pesquisa levanta a hipótese "de que muitas das citações concernentes ao abandono e/ou negligência sejam também consequência de um contexto social em que a luta pela sobrevivência resulta no abandono dos próprios filhos, por falta de condições de educá-los" (AASPTJ-SP/NCA-PUCSP/SAS/FUNDAÇÃO ORSA, 2003, p. 153).

A pobreza ainda é o pano de fundo da maioria dos abrigamentos. No entanto, deve-se tomar muito cuidado com as possíveis interpretações de afirmações como essa, para não cair no reducionismo de patologizar a pobreza, articulando-a necessariamente à violência.

Em seguida, aparecem a violência física intrafamiliar (10,3\%) e o uso de drogas e álcool por parte dos familiares $(9,8 \%)$. O fato dessas motivações aparecerem de modo tão próximo em termos percentuais pode indicar que esses motivos estão relacionados, ou seja, "sugere a possibilidade de que muitos dos casos de violência e maus-tratos sejam resultado do uso abusivo do álcool ou outras drogas" (AASPTJ-SP/NCA-PUCSP/SAS/FUNDAÇÃO ORSA, 2003, p. 184).

\footnotetext{
${ }^{36}$ Neste estudo, serão adotadas as definições de negligência e abandono que estão propostas no PNCFC (2006). Este relaciona três tipos de violência: negligência, abandono e violência doméstica. Na definição de negligência cita o trabalho de Azevedo e Guerra (2003) para os quais esta "se configura quando os pais (ou responsáveis) falham em termos de atendimento às necessidades dos seus filhos (alimentação, vestir, etc.) e quando tal falha não é o resultado das condições de vida além do seu controle". Um exemplo talvez ajude a compreender a definição: é negligente uma mãe que deixa de vacinar seus filhos mesmo sabendo que é sua obrigação fazê-lo. Caso essa mãe não soubesse dessa obrigação, por desconhecimento ou qualquer outro motivo justificável, ela não poderia ser considerada negligente. A negligência implica em um ato consciente de descaso por parte de quem a pratica. Por abandono, o PNCFC considera que essa forma de violência pode ser pensada como a forma mais grave de negligência quando o adulto responsável deixa a criança/adolescente solta à sua própria sorte.

A violência doméstica pode ser desmembrada em outras três: a violência física, psicológica e sexual. Todas elas envolvem o uso da força ou da intimidação para agir sobre alguém ou fazê-lo agir contra sua vontade.
} 
É importante frisar que o abuso de drogas, assim como os problemas mentais do pai ou da mãe $(5,2 \%$ ) (cf. AASPTJ-SP/NCA-PUCSP/SAS/FUNDAÇÃO ORSA, 2003, p. 184) não podem ser considerados motivos de abrigamento por si só. É preciso perceber se essas condições estão colocando a criança ou o adolescente em risco ou não, o que nem sempre é fácil de se fazer. Apesar da maioria dessas situações se constituírem em violações contra a criança ou adolescente, esses são momentos nos quais não se pode simplesmente ter por base as estatísticas, pois é possível que um usuário de drogas ou alguém com problemas mentais seja extremamente carinhoso e atencioso com seus filhos, cuidando deles da melhor maneira que consegue. Nesse caso, é preciso que essa pessoa seja ajudada a cuidar de seus filhos e não ser separada deles.

A pesquisa de Fávero, Vitale e Baptista (2008) aponta uma porcentagem ainda maior de familiares com doenças no campo da saúde mental:

[...] 16\% com diagnóstico psiquiátrico, $11 \%$ com dependência de álcool, $8 \%$ com diagnóstico psicológico e 3\% com dependência de outros entorpecentes [...] a precariedade da condição socioeconômica a que essa população está submetida e a luta árdua e cotidiana pela sobrevivência podem desencadear ou agravar os problemas de saúde, especialmente aqueles relacionados à esfera mental. A dependência de álcool e de outras drogas, muitas vezes, é uma estratégia, ainda que defensiva, para enfrentar a problemática vivenciada. (p. 54)

De fato, a elevada quantidade de familiares com algum tipo de doença crônica ou frequente (51\%) (FÁVERO, VITALE \& BAPTISTA, 2008, p. 53), não só as doenças de cunho mental, chama atenção. As relações entre pobreza e saúde já foram muito discutidas e escapam do escopo deste trabalho, especialmente em relação às doenças mentais. Pretende-se simplesmente questionar a presença do abrigamento nesse processo, perguntando se ele se coloca como auxilio à cura ou como mais um sintoma que essas famílias terão que tratar? De qualquer modo, vale destacar que com uma política mais efetiva de tratamento ao usuário de drogas e pessoas com problemas relacionados à saúde mental, muitas crianças deixariam de ser abrigadas.

Em seguida, tem-se o dado de que

[...] em $7,1 \%$ o abrigamento foi feito por terceiros que não puderam arcar com a responsabilidade de cuidar das crianças, configurando-se possivelmente um quadro de "circulação de crianças" antes do abrigamento. Muitas crianças são criadas por terceiros sem que haja qualquer legalização da situação, mas para outras tantas, isso deixa de ser possível, ao enfrentar-se dificuldades socioeconômicas ou mesmo relativas a problemas de 
comportamento que venham a apresentar. (AASPTJ-SP/NCAPUCSP/SAS/FUNDAÇÃO ORSA, 2003, p. 185)

Da maneira como a citação acima está formulada, tem-se uma impressão um tanto negativa da chamada "circulação de crianças", talvez pela valorização excessiva da regularização legal dessas situações. No entanto, não se percebe esse movimento como necessariamente ruim, mas sim como algo que, muitas vezes, pode ser uma estratégia alternativa de cuidados com os filhos, característica das classes populares. É essa estratégia mais comunitária de educação de crianças que está presente nesse "cuidado por terceiros", e que se expressa também na valorização das relações de vizinhança, no suporte mútuo etc., algo mais desconhecido das classes médias e altas. Ao observar

[...] a prática de circulação de crianças como uma estrutura básica da organização de parentesco em grupos brasileiros de baixa renda, nossas atenções se deslocam de um "problema social" para um processo social, e nosso enfoque analítico muda de "o colapso dos valores tradicionais" para formas alternativas de organização vinculadas a uma cultura popular urbana. (FONSECA, 2002, p. 15 apud FÁVERO, VITALE \& BAPTISTA, 2008, p. 72)

Considera-se até que o estudo dessa especificidade das classes populares poderia ser muito útil para os próprios abrigos repensarem suas práticas educativas, já que essas instituições também não deixam de ser propostas de educação comunitária.

Além disso, parece a esta pesquisa que o alargamento e a flexibilização da noção de família, trazido pela Constituição de 1988, pelo ECA e demais normativas jurídicas, que reconhece os laços afetivos como tão importantes quanto os laços de sangue, representa uma importante legitimação dessas formas alternativas de cuidado. Nesse sentido, família é aquele grupo de pessoas com quem se estabelece um sistema de ajuda, sendo muito comum, nesses casos, as famílias (de origem e cuidadora) manterem contato, e a criança ou adolescente chamar de "mãe" as duas mulheres que tem como sua referência.

A "circulação de crianças" pode, inclusive, constituir-se como fator preventivo ao abrigamento ou mesmo como um facilitador do desabrigamento de crianças e adolescentes.

Por outro lado, não se pode deixar de ponderar que esse fenômeno característico das famílias pobres é carregado de ambiguidades.

Em que pese a possibilidade dessa estratégia ser utilizada como hábito cultural, representa mais uma vez a impossibilidade da família de origem de reunir condições socioeconômicas para cuidar e educar seus filhos, e a 
ausência do Estado no que se refere a políticas de proteção social. (FÁVERO, VITALE \& BAPTISTA, 2008, p. 72)

De fato, o que se percebe é que as famílias que possuem crianças e adolescentes abrigados são justamente aquelas que não conseguem se constituir como um "sistema de ajuda". Basta comparar os dados da renda individual com a renda familiar para evidenciar essa situação:

Tabela 1 - Renda Individual Mensal

\begin{tabular}{l|c} 
Renda & $\%$ \\
\hline Menos de 1 SM & $25 \%$ \\
\hline 1 a 2 SM & $33 \%$ \\
\hline 2 a 3 SM & $6 \%$ \\
\hline 3 a 4 SM & $10 \%$ \\
\hline Acima de 4 SM & $6 \%$ \\
\hline Sem renda & $16 \%$ \\
\hline Sem informação & $2 \%$ \\
\hline Resposta prejudicada & $2 \%$ \\
\hline Total & $100 \%$ \\
\hline
\end{tabular}

Tabela 2 - Renda Familiar Mensal

\begin{tabular}{l|c} 
Renda & $\%$ \\
\hline Menos de 1 SM & $14 \%$ \\
\hline 1 a 2 SM & $42 \%$ \\
\hline 2 a 3 SM & $12 \%$ \\
\hline 3 a 4 SM & $10 \%$ \\
\hline Acima de 4 SM & $10 \%$ \\
\hline Sem renda & $10 \%$ \\
\hline Não soube informar & $2 \%$ \\
\hline Total & $100 \%$ \\
\hline
\end{tabular}

Apesar de algumas variações, as rendas individual e familiar apresentam valores relativamente próximos e ainda são "incapazes de indicar alterações nas condições gerais de pobreza, vulnerabilidade e risco social dos grupos familiares envolvidos" (FÁVERO, VITALE \& BAPTISTA, 2008, p. 87). Uma pequena variação entre as rendas de um único indivíduo e a de sua família como um todo mostra que, pelo menos na função de provisão, essas famílias não se constituem como sistemas de ajuda mútua, estando, na realidade, essa tarefa concentrada em torno de um único indivíduo. 
É nesse quadro de enfraquecimento familiar que o abrigo desponta como uma salvação, na visão dessas famílias. De modo equivocado, a instituição de abrigamento penetra na dinâmica simbólica desses grupos fazendo as vezes de um sistema de ajuda, uma vez que os pais não mais precisam se preocupar com o sustento dos filhos enquanto estes estiverem institucionalizados. Quando o abrigamento ocorre para dar conta de situações estritas de pobreza, ao invés de proteção à criança ou ao adolescente abrigado, ele transforma-se, para essas famílias, em simplesmente "menos uma boca para alimentar".

O abrigamento por motivo de falecimento do pai e/ou da mãe foi apontado em 7,1\% das respostas (cf. AASPTJ-SP/NCA-PUCSP/SAS/FUNDAÇÃO ORSA, 2003, p. 184). Mais uma vez, esse motivo, assim como o cumprimento de pena por parte do pai ou da mãe $(3,8 \%)$ (cf. AASPTJ-SP/NCA-PUCSP/SAS/FUNDAÇÃO ORSA, 2003, p. 184), não pode determinar "automaticamente" o abrigamento, visto que sempre se deve procurar outros familiares que possam ficar com as crianças e adolescentes em questão. Esse número reduzido de abrigamento por orfandade é mais um elemento que ajuda a se desfazer o mito recorrente, como apontado anteriormente, que paira sobre os meninos e meninas de abrigo: o de que seriam todos órfãos. Viu-se, também, que a maioria dessas crianças e adolescentes tem família, sendo, na realidade, melhor definidos como "órfãos de pais vivos" (cf. VICENTE, 1999).

Em seguida, a pesquisa realizada na cidade de São Paulo aponta os "problemas de comportamento da criança ou adolescente" como motivo de abrigamento para $3,8 \%$ dos casos (cf. AASPTJ-SP/NCA-PUCSP/SAS/FUNDAÇÃO ORSA, 2003, p. 184). Apesar de pouco representativo dentro da amostra geral, essa modalidade de encaminhamento é bastante reveladora de certa visão, ainda muito presente no imaginário social, do abrigo como reformatório, ou seja, uma instituição de caráter moral para crianças e adolescentes com mau comportamento e com o objetivo de "reformar" aqueles que se desviam das normas. Ressaltese que essa situação não se configura como motivo de abrigamento, tendo o acolhimento institucional o único efeito de retirar da família a autoridade necessária para educar seus filhos. Um encaminhamento como esse, ao invés de fortalecer o grupo familiar em conflito, acaba simplesmente por separar as partes queixosas, resolvendo apenas ilusoriamente o conflito intrafamiliar instalado.

Essa concepção dos abrigos como instituições de correção é oriunda dos antigos projetos educacionais dos orfanatos, educandários e internatos, que objetivavam acolher esses "desviados" para devolvê-los cidadãos sadios à sociedade quando completassem a maioridade. Na realidade, tudo o que conseguiam fazer era culpabilizar o indivíduo que, na 
realidade, era vítima de uma questão social muito maior do que ele. Fica claro que o conceito de proteção subjacente a essas práticas é individualizar as responsabilidades sobre uma situação de vulnerabilidade social e visa muito mais proteger a sociedade do que a própria criança ou adolescente, ou seja, volta-se para proteger o agressor ao invés da vítima. A utilização dos mecanismos de proteção dessa época (e presentes até hoje, ainda que de forma residual) visavam a desresponsabilização da sociedade face às violações de direitos que ela mesma produzia.

A situação de rua aparece como motivação para a institucionalização em 6,1\% dos casos (cf. AASPTJ-SP/NCA-PUCSP/SAS/FUNDAÇÃO ORSA, 2003, p. 184). Deseja-se ressaltar que o presente estudo se posiciona contra o abrigamento por situação de rua, o que não quer dizer que as crianças ou adolescentes que se encontram nas ruas não possuam o direito de serem protegidos, inclusive em abrigos, caso seja necessário. No entanto, abrigar pelo motivo estrito de se estar na rua representa um desconhecimento a respeito dessa situação. Isso porque a situação de rua é sempre consequência de uma violência, e não sua causa. Ninguém vai para a rua simplesmente porque quer. Ir para a rua normalmente significa um movimento empreendido pela criança ou adolescente para fugir de alguma situação que lhe é incômoda ou mesmo insuportável, ou seja, pode ser entendido como um ato extremamente saudável. Sendo assim, antes de se abrigar um menino ou menina que está na rua, é preciso investigar as causas de ele estar na rua e ponderar se essas causas são ou não motivos que justificam um abrigamento.

Para se abrigar um menino que está na rua é preciso enxergar além da situação de rua, avaliando se os motivos que o levaram para a rua são efetivamente motivos que justificam o abrigamento.

Destaca-se ainda o fato de a pesquisa da AASPTJ-SP/NCA-PUCSP/SAS/Fundação Orsa (2003) ter apontado a proteção à vida em $0,8 \%$ dos casos de encaminhamento ao abrigo (p. 184). Esse motivo refere-se "ao risco de vida em razão da periculosidade do local de moradia (com ameaça de morte por traficantes). Apesar de praticamente irrelevante no universo geral paulistano, esse destaque se justifica, pois suspeita-se que essa porcentagem é muito maior em outras cidades, uma vez que São Paulo é um município que conta com Programa de Proteção a Crianças e Adolescentes Ameaçados de Morte (PPCAAM). Assim, esse programa atende a demanda de ameaçados de morte que, em muitos outros municípios, acaba sendo absorvida pelos abrigos.

É preciso novamente deixar claro que este estudo se declara contra o abrigamento por ameaça de morte pelos seguintes motivos: normalmente não é só a criança ou o adolescente 
que está em situação de risco quando é ameaçado, mas sim toda a sua família. Desse modo, é o núcleo familiar inteiro que necessita de proteção. Outro razão é a de que, por mais que não se divulgue maciçamente a localização dos abrigos, não é tão difícil assim encontrá-los, uma vez que são equipamentos públicos com intensa relação com a comunidade ao seu redor. Assim, a presença de alguém ameaçado de morte no interior de um abrigo coloca todos os demais abrigados, bem como os próprios funcionários, em risco também. Abrigar um ameaçado de morte não é protegê-lo do risco, é simplesmente pulverizar a ameaça para todos aqueles que passam a se relacionar com ele.

Desse modo, o ameaçado de morte precisa de uma proteção específica, que não pode ser oferecida pelos abrigos, mas sim por um programa especializado nessa demanda, como o PPCAAM.

Vale destacar que, embora as pesquisas analisadas não tenham apontado, a questão das crianças e dos adolescentes desaparecidos pode vir a se tornar uma situação de abrigamento, dependendo do caso. O PNCFC aponta um número bastante expressivo desses incidentes: aproximadamente 40.000 registros anuais de desaparecimento nas delegacias de todo o país, sendo que "em $73 \%$ dos casos estudados, o desaparecimento tratava-se de fuga de casa, motivada, principalmente, por situações de maus-tratos, alcoolismo dos pais, violência doméstica e abuso de drogas" (PNCFC, 2006, p. 56). O "desaparecimento" é, nesses casos, um saudável movimento de defesa daqueles que estão em situação de violência.

Isso significa que é muito provável que os abrigos acabem recebendo essas crianças e adolescentes e precisem intervir no sentido protegê-las, trabalhar com suas famílias e mediar o seu retorno a elas, quando houver possibilidade para tal.

Uma dica importante é a consulta ao Cadastro Nacional de Crianças e Adolescentes Desaparecidos, disponível ao público na internet por meio do endereço eletrônico www.desaparecidos.mj.gov.br. Vale destacar que esse cadastro registra, em sua maioria, os desaparecimentos persistentes, ou seja, aqueles que ultrapassam os 30 dias de duração.

Ainda, deseja-se fazer um apontamento sobre a ausência de uma motivação de abrigamento em especial: a violência sexual. Sendo um motivo bastante característico da demanda de abrigamento, dado a gravidade da violência em questão, intriga o fato dela não constar nem na pesquisa na cidade de São Paulo nem no Levantamento Nacional. Pode-se levantar como hipótese explicativa dessa ausência o "pacto de silêncio" que normalmente é construído em torno desse tipo de violência, tão forte que não é quebrado nem quando o caso é encaminhado ao abrigo. 
De maneira geral, em relação a todos os motivos de abrigamento acima apresentados, serão feitos dois comentários.

Primeiramente, é preciso deixar bem claro que os motivos de abrigamento não passam de abstrações, frutos do ímpeto costumeiro de segmentar para compreender. Obviamente que dividi-los de modo tão detalhado tem suas vantagens, na medida em que possibilita organizar melhor as reflexões e os apontamentos. No entanto, não se pode esquecer que a realidade é sempre mais complexa do que as tentativas de enquadrá-la em categorias. Assim, quando se trabalha nos abrigos, percebe-se que esses motivos apresentam-se misturados, sendo que os casos normalmente comportam mais de um motivo de encaminhamento para a instituição. Nesse sentido, o trabalho com essas crianças e adolescentes abrigados e suas famílias não pode ser compartimentalizado tal como costuma ser o conhecimento sobre sua realidade. É preciso se ter claro que, no limite, todo abrigamento é motivado por um contexto de fatores e é sobre essa complexidade que se deve atuar.

Em segundo lugar,

[...] os motivos citados parecem estar relacionados à precariedade de políticas públicas que atendam à demanda dessa população. Políticas direcionadas à habitação, à saúde, à educação e ao trabalho certamente concorreriam para que grande parte dessas crianças e adolescentes permanecesse com seus familiares. (AASPTJ-SP/NCAPUCSP/SAS/FUNDAÇÃO ORSA, 2003, p. 186)

Diante desse quadro de precarização da vida, não só as próprias famílias, como também as redes de proteção social "vêem o abrigo como solução para o contexto de exclusão" (AASPTJ-SP/NCA-PUCSP/SAS/FUNDAÇÃO ORSA, 2003, p. 186).

No entanto, viu-se que o abrigo não pode ser concebido como medida de combate à exclusão social. Ele é uma forma de proteção a uma das expressões da exclusão social, que é a violência intrafamiliar contra crianças e adolescentes. Embora absolutamente necessário, o abrigamento deve ser tomado como uma medida específica, ou seja, necessária para certos casos em particular, como tentou-se esclarecer nas reflexões sobre os motivos de encaminhamento às instituições de acolhimento. Caso contrário, se o abrigo não for tomado em sua especificidade, ele transforma-se em seu oposto: de uma medida de proteção passa a ser mais uma forma disfarçada de exclusão social dos filhos pobres da sociedade.

Ainda em relação aos motivos de abrigamento, a pesquisa de Fávero, Vitale e Baptista (2008) revela o outro lado da questão: o modo como as próprias famílias enxergam os motivos de abrigamento de seus filhos. 
Como motivação mais frequente foi apontada a questão do desemprego, responsável por $13 \%$ das respostas (p. 33). Curiosamente, não aparece a "pobreza" propriamente dita na fala dos familiares, talvez indicando vergonha de se assumirem como pobres em uma sociedade que ainda vê o pobre com maus olhos, como se apenas este fosse responsável por sua condição de miserabilidade. $\mathrm{O}$ desemprego funciona na fala dessas famílias quase como um equivalente da pobreza, valendo mesmo como um eufemismo: é algo que faz sentido na realidade dos pais e não na das crianças e adolescentes. Em verdade, tal como na pobreza, nada na situação de desemprego justifica qualquer tipo de agressão contra crianças e adolescentes, apesar de se reconhecer nessas situações fatores indutores de violência. Até porque, existem pobres e/ou desempregados que não cometem violência contra seus filhos nem têm seus filhos institucionalizados, o que indica que a privação de recursos materiais ajuda a compreender, mas não esgota o fenômeno de uma família agressiva. A pobreza nunca é o motivo da violência. Ela atravessa todas as classes sociais e está condicionada a outros fatores que podem ser potencializados pela pobreza, mas que, em essência, podem estar a ela relacionados ou não. Para aqueles que trabalham cotidianamente com essas famílias, deve-se tomar cuidado para que a pobreza não saia do lugar de contexto do abrigamento e passe a ser sua justificação, ou seja, a pobreza não pode se tornar uma "desculpa" para a família, por mais pobre que ela seja.

Vale a pena destacar também que diversas formas de violência aparecem de modo explícito na fala dos familiares: negligência familiar (11\%), violência por parte de outra pessoa do convívio (7\%), abandono materno (6\%), abandono paterno (2\%) e violência por parte do entrevistado (1\%) (FÁVERO, VITALE \& BAPTISTA, 2008, p. 33). Nota-se, contudo, uma grande dificuldade de assumir a violência quando se é o autor dela. As situações de violência parecem ser tendenciosas a desenvolver um mecanismo de projeção e deslocamento, de modo que a violência ou mesmo a responsabilidade por ela se encontra sempre distante, no outro, e nunca em si mesmo. Tudo se passa como se autor da violência respondesse automaticamente a um determinante externo, eximindo-o de qualquer responsabilidade.

Ainda, é importante ressaltar na fala das famílias a grande e diversificada quantidade de motivos de abrigamento que, de fato, não são motivações que justificariam o encaminhamento ao abrigo: para não ficar na rua (10\%), evitar envolvimento com más companhias (3\%), não tinha onde deixá-lo no horário de trabalho (2\%), dava muito trabalho/não obedecia (2\%). Ainda foi identificada uma grande quantidade de "outras respostas" $(23 \%)$ dentre as quais destacam-se as mais significativas ou mesmo curiosas: falta 
de alimentos, ferimento com "rojão", falta à escola etc. (FÁVERO, VITALE \& BAPTISTA, 2008, p. 33).

Já se discutiu algumas das justificativas apontadas, tais como não ter onde deixar o filho enquanto se trabalha, situação que uma creche resolveria, e a questão da desobediência, situação essa em que se propõe uma reflexão acerca da diferença de proposta pedagógica entre os atuais abrigos e os antigos reformatórios.

As questões que falam do abrigo como solução para que crianças e adolescentes não fiquem na rua ou não se envolvam com más companhias, fazem com que se pense na urgência da ampliação dos programas de educação integral ou de projetos socioeducativos no contraturno escolar. Assim como as creches, tais programas, ao preencherem o cronograma das crianças e adolescentes com atividades saudáveis durante todo o dia, além de se adequarem muito melhor às demandas familiares acima referidas, ainda representam um forte impulso na direção da prevenção à institucionalização.

Vale lembrar que os motivos acima apontados não correspondem aos motivos "reais" de encaminhamento aos serviços de acolhimento institucional, mas sim ao modo como eles foram percebidos pelas famílias que tiveram seus filhos abrigados. Dessa maneira, percebe-se um desconhecimento generalizado a respeito da separação pela qual eles próprios estão passando e mesmo a respeito do que é o próprio abrigo e o significado da proteção que ele oferece.

Em termos genéricos, se as famílias parecem desenvolver uma retórica de coletivização das culpas e desresponsabilização, a visão dos próprios abrigados a respeito de seu encaminhamento aos serviços de acolhimento remete, ao contrário, a discursos autoculpabilizadores, com as crianças e adolescentes identificando a si próprios como os responsáveis pela institucionalização.

Entrevistador: O que aconteceu, por que você veio [para o abrigo]?

Criança: Porque minha mãe não me agüentava.

[...]

Entrevistador: E agora porque você não vai para casa?

Criança: Eu tenho vergonha de falar. É porque eu vendia rosas, porque precisava de dinheiro para pôr dentro de casa. [...] Tem que se comportar para voltar, não pode bagunçar...”. (OLIVEIRA, 2007, p. 34)

Segundo a autora, esse é o relato de um menino de 10 anos que passou metade de sua vida abrigado. Mesmo depois de tantos anos, ele ainda acredita que foi o responsável por sua institucionalização e que, para sair, é necessário que ele se comporte. 
A partir dessas falas, fica claro que pais e filhos estão passando pelo processo de abrigamento às escuras, sem os conhecimentos e esclarecimentos necessários para elaborarem e ressignificarem essa experiência de modo menos traumático. Tem-se, de um lado, pais que não sabem o porquê dessa história de sofrimento ter começado e, de outro, filhos que desconhecem como e quando ela vai acabar.

Em resumo, Fávero, Vitale e Baptista (2008) interpretam as falas das famílias e os dados que se consolidaram a partir delas como reflexos da condição social de pobreza e miserabilidade à qual elas estão expostas:

\begin{abstract}
De maneira acentuada, expressões da questão social, como desemprego, ausência ou condições precárias de moradia, ausência de equipamentos sociais públicos para acolher a criança/adolescente em horário de trabalho da família, revelam que a acentuada e histórica desigualdade social presente na realidade brasileira se coloca no centro da institucionalização de crianças e adolescentes. (p. 35)
\end{abstract}

Concorda-se com a interpretação acima. No entanto, este estudo quer acrescentar a ideia de que toda essa situação descrita na citação anterior engendra em determinadas famílias um movimento de desresponsabilização no cuidado com seus filhos, processo que pode desembocar no abrigamento dessas crianças e adolescentes.

Ao contrário de se retomar o velho discurso culpabilizador das famílias que possuem seus filhos abrigados, essa nova ideia visa implicar a própria família agressora na reprodução das situações de violência às quais ela mesma está exposta e, consequentemente, de colocá-la, não como culpada, mas como corresponsável, juntamente com o Estado e toda a sociedade, no processo de produção de um abrigamento. Como em jogo de empurra, as famílias tentarão se passar por vítimas, enquanto o restante da sociedade as verá como culpadas. Inclusive no campo da produção de conhecimento, a tendência em relação às famílias que possuem crianças ou adolescentes abrigadas é tomá-las ora pelo viés da vitimização, ora da culpabilização, "obscurecendo a dimensão do lugar que ocupam como atores sociais, detentores de direitos e deveres no exercício da cidadania" (OLIVEIRA, 2003, p. 374). O esforço deverá ser o de escapar dessa dicotomia, ponderando as responsabilidades de cada um. Particularmente, para pensar essas ambiguidades, o presente trabalho se apóia na ideia de “cúmplice”: não desresponsabiliza, mas também não culpabiliza. A família não é somente vítima, pois também é agressora. Mas também não somente agressora, pois também é vítima. No fundo, é cúmplice da violência que vem do social, mas que ela reproduz no âmbito 
privado. O agressor é simplesmente aquele que não conseguiu romper o ciclo de reprodução da violência que ele mesmo sofreu.

Sem esse necessário movimento de implicação da família violenta na própria violência que ela não simplesmente reflete, mas também "re-produz" corre-se o risco de que uma interpretação crítica da realidade social dessas famílias passe a ser uma justificativa dos atos violentos por elas cometidos. Sem se pensar nos mecanismos pelos quais a desigualdade social adentra as portas das famílias pobres e transforma-se, em seu interior, em violência contra crianças e adolescentes, continuar-se-á a reeditar o antigo discurso da incapacidade das famílias pobres para o cuidado digno de seus filhos que, ao culpabilizá-las, também as invisibilizava.

Toda violência tem a sua história. Uma parte dela é coletiva e corresponde, em suas linhas gerais, ao apresentado pela pesquisa de Fávero, Vitale e Baptista (2008). No entanto, existe outra parte que é íntima, singular de cada indivíduo ou família violenta. Sem a apreensão dessa segunda parte, dessa parte escondida, mantêm-se essas famílias tão invisíveis quanto estavam antes, apesar de atualmente serem invisibilizadas por um discurso politicamente correto. Elas continuam escravizadas, apenas sob o jugo de um senhor diferente.

A compreensão das famílias como reprodutoras e também como coprodutoras da violência que vem do social é importante para que as críticas tecidas às condições atuais dos abrigos e da rede de proteção à infância e à adolescência como um todo não conduzam a uma das grandes armadilhas do trabalho em instituições de acolhimento: a idealização da "volta ao lar", que pode ser localizada inclusive nos documentos oficiais de normatização dos abrigos.

Essa discussão passa necessariamente por uma valorização exacerbada do ambiente familiar sempre considerado o melhor possível para uma criança ou adolescente viver, esquecendo-se das agruras e violências a que foram submetidas no interior do mesmo. Essa pesquisa quer apontar como um dos maiores desafios das práticas de acolhimento institucional, a desconstrução da dicotomia estanque entre permanência no abrigo como algo necessariamente ruim e retorno à família como algo necessariamente bom. Existem certas situações nas quais o ato mais saudável que uma criança ou adolescente pode ter é fugir de sua família. Nesses casos, o retorno ao lar torna-se extremamente delicado. (Existe aqui um paralelo possível com uma discussão mais estabelecida em educação e psicologia escolar, no que se refere à reinterpretação da indisciplina não como um ato agressivo gratuito, mas como uma tentativa de se dizer algo, como um meio de se falar algo que não se enuncia de outra 
maneira. Nesse sentido, o que uma criança ou um adolescente estaria nos dizendo quando foge de casa?)

Este trabalho não se coloca contra a diretriz de "retorno à família" estabelecida nas leis e nos documentos oficiais de orientação às práticas de abrigamento. Considera-se tal foco essencial e, inclusive, ele é portador de uma função política importante. Ele é, na realidade, uma escolha historicamente informada, que tenta resgatar aquilo que o passado autoritário renegou, mesmo correndo o risco de, às vezes, exagerar para o lado contrário.

Desse modo, apesar de crucial enquanto diretriz geral, ela torna-se insuficiente quando se debruça sobre o cotidiano das instituições, quando se depara com famílias extremamente violentas e resistentes às intervenções das equipes dos abrigos.

Obviamente, pôde-se, em vários momentos desta pesquisa, apontar as inúmeras deficiências existentes atualmente nos abrigos do Brasil o que, em muitos casos, inviabiliza que essas instituições possam realmente assumir a tarefa que lhes cabe, a de apoiar as famílias, tarefa essa que é uma parte essencial de suas atribuições.

Este trabalho coloca-se absolutamente a favor do reordenamento dos abrigos e, por isso mesmo, acumula legitimidade para apontar os desafios e as limitações das organizações que estão ao redor dos abrigos, inclusive a família. O desafio é pensar que um acolhimento institucional pode ser algo extremamente positivo na história de vida de uma criança ou adolescente vitimizado por sua família, mesmo que ele permaneça no abrigo até a maioridade. Obviamente, não se trata de demonizar ou culpabilizar as famílias, mas sim de reconhecer suas mazelas e o fato de que, em muitos casos ou por determinado período de tempo, algumas delas não se constituirão no melhor lugar para o desenvolvimento de seus filhos.

A análise dos motivos que essas famílias denotam ao abrigamento de seus filhos revela, na realidade, suas concepções a respeito da produção da violência em seu interior. Por outro lado, o estudo das interpretações feitas a partir dessas falas indicou que elas padecem de uma identificação muito intensa com o objeto de suas investigações, transformando-se em um discurso extremamente colado às falas que analisa. Não se percebe contradições e ambiguidades, mas apenas continuidade.

A ideia de um processo de desresponsabilização pode possuir o mérito de pensar na implicação das famílias de crianças e adolescentes abrigados na coprodução do abrigamento sem, no entanto, culpabilizá-las como a antiga noção de incapacidade fazia. Sem essa implicação, ou seja, concebendo-as simplesmente como reflexos da condição social à qual estão expostas, relega-se a elas um papel de meras expectadoras na dinâmica de violência que se instaurou em seu interior. Nesse sentido, pode-se identificar a atribuição de um lugar de 
passividade dessas famílias. Somente pensando nessas famílias como corresponsáveis pela produção da violência geradora do abrigamento é que poder-se-á trabalhar com elas como protagonistas no processo de desabrigamento.

Tal questão está presente também nos próprios documentos orientadores da política pública de abrigos, cuja contradição passa por, com a intenção de combater séculos de preconceito contra a família pobre, concebê-las como reflexos da condição social e, ao mesmo tempo, desejar que sejam protagonistas da transformação dessa mesma condição.

\subsubsection{O tempo de abrigamento: a provisoriedade em questão}

Tem-se, ainda, como tarefa de caracterização das crianças e dos adolescentes que estão em medida de abrigo a apresentação de alguns dados a respeito do seu tempo de permanência nessas instituições. O tempo de abrigamento expressa a efetivação ou não do princípio de provisoriedade consagrado no Estatuto. Assim, ao se estudar quanto tempo uma criança ou adolescente permanece abrigada se está, na realidade, indagando a respeito do próprio sentido da medida de acolhimento institucional, já que ela só se justifica se for provisória.

O Levantamento Nacional revela que a maior parte $(32,9 \%)$ das crianças e adolescentes fica abrigada por um período que varia entre dois a cinco anos (cf. IPEA, 2003, p. 4).

Na cidade de São Paulo, apesar da faixa de maior concentração corresponder ao período de um a dois anos $(16,1 \%)$, quando se soma as porcentagens das crianças e adolescentes abrigadas a mais de dois anos chega-se ao número de 52,9\% (AASPTJ-SP/NCAPUCSP/SAS/FUNDAÇÃO ORSA, 2003, p. 187).

Curiosamente, a pesquisa de Fávero, Vitale e Baptista (2008) revela dados bastante discrepantes: o maior percentual encontrado foi o de $32 \%$ das crianças e adolescentes que se encontravam abrigados por um período inferior a seis meses. O índice correspondente ao período de mais de dois anos é de $37 \%$ (cf. 31).

Algumas explicações poderiam ser levantadas para compreender essa diferença: o tempo de cinco anos entre a realização das pesquisas, o que indicaria uma melhora tão acelerada na política pública de abrigamento em São Paulo que torna essa hipótese pouco crível. Além disso, existe a óbvia diferença de confiabilidade dos dados, já que a segunda não se configurou em um levantamento exaustivo como a primeira. No entanto, apesar de 
investigar uma amostragem sensivelmente menor, ela é estatisticamente relevante e, em outros dados, os índices de ambas as pesquisas se apresentam com números semelhantes. As próprias autoras tentam levantar explicações, sugerindo que tal índice poderia estar trazendo “indicativos de que crianças e adolescentes têm permanecido acolhidos por curto período de tempo, ou de que, nos meses anteriores à aplicação da pesquisa, ocorreu um aumento do número de abrigamentos" (FÁVERO, VITALE \& BAPTISTA, 2008, p. 31).

Do ponto de vista do presente estudo, a discrepância entre os índices pode ser melhor compreendida a partir de uma restrição metodológica: o tempo de abrigamento é menor, pois o estudo em questão investigou crianças e adolescentes que recebiam visitas no abrigo, característica que não está presente em todo o universo de crianças e adolescentes abrigados. Nesse sentido, o que em outros momentos significou uma restrição da confiabilidade dos dados quando generalizados para o universo de abrigados em geral, aqui, serve para reafirmar a importância da presença da família nas visitas ao abrigo, pois tais meninos e meninas permanecem institucionalizados por um tempo significativamente menor.

De maneira geral, a avaliação dos dados agora apresentados é difícil, uma vez que não há definição legal do tempo que pode ser considerado "provisório". Apesar disso, tanto o Levantamento Nacional como a pesquisa da AASPTJ-SP/NCA-PUCSP/SAS/Fundação Orsa (2003) tomaram o período de dois anos como o marco referencial na definição da provisoriedade. Assim, a partir dessas categorizações, fica muito nítido que o princípio da provisoriedade, consagrado pelo ECA, não está sendo respeitado.

No entanto, uma definição objetiva de provisoriedade é, no limite, impossível. É, na verdade, uma contradição à própria noção de provisório, que poderia ser conceitualizado como mínimo tempo possível de abrigamento para cada caso.

Desse modo, a definição objetiva da provisoriedade seria muito mais uma questão estratégica do que conceitual, ou seja, é importante como mecanismo de pressão para que, por exemplo, se redobre os esforços de desabrigamento após esse período estipulado. Estrategicamente, ou seja, em termos gerais, dois anos poderiam servir como meta para que a grande maioria dos desabrigamentos ocorra antes desse tempo. Mas, conceitualmente, não se pode esquecer que o que vale como princípio metodológico para o trabalho de desabrigamento é, sempre, o tempo mínimo possível. Dois anos não pode servir como o tempo aceitável de permanência no abrigo. O tempo aceitável é, idealmente, o mínimo possível.

Provisório também significa que não se deve conceber o abrigo como opção de moradia definitiva para qualquer criança ou adolescente. Provisório não quer indicar que o 
acolhimento institucional é necessariamente ruim. Ao contrário, desde que bem aplicada, a medida de abrigamento se constitui em algo extremamente benéfico para a criança ou adolescente. No entanto, é um "bem" que não pode ser eternizado: algo que é bom no presente não necessariamente continuará a ser bom no futuro. $\mathrm{O}$ abrigo é exemplo de um "bem" que, se perdurado por muito tempo, transforma-se em um "mal". Nesse sentido, a provisoriedade vem reiterar que a reintegração familiar deverá ser sempre o objetivo do trabalho dessas instituições. ${ }^{37}$

Para além dessas questões, o tempo médio de abrigamento é, normalmente, um bom indicativo de resultado do trabalho de cada instituição. "O tempo de abrigamento representa um índice da necessidade de trabalhos específicos junto a determinados abrigos, sugerindo-se o investimento de ações em parceria com a rede de atendimento com tal objetivo" (AASPTJSP/NCA-PUCSP/SAS/FUNDAÇÃO ORSA, 2003, p. 189). Em outras palavras, essa informação se configura como um importante instrumento de gestão da política pública, podendo ser a medida, por exemplo, para a prioridade de investimentos em capacitação e supervisão. $^{38}$

\subsubsection{Algumas características psicológicas da criança ou adolescente abrigado: esboço de uma psicodinâmica do abandono}

Quem começa a trabalhar em abrigos costuma estranhar uma insistente pergunta feita por esses meninos e meninas toda vez que o horário de trabalho termina e o funcionário se dirige em direção ao portão de saída do abrigo: “Tio, você vem amanhã?”.

\footnotetext{
${ }^{37}$ No entanto, existirão situações em que esse objetivo simplesmente não será possível de ser concretizado, seja pela ausência total de família associada à improbabilidade de adoção (um adolescente, por exemplo), seja por causa de uma família extremamente violenta e resistente às propostas de trabalho. Discutimos melhor casos como esse quando falamos, no item sobre os tipos de abrigos, das instituições de longa permanência. Esses serviços são, na realidade, o reconhecimento da rede de proteção de que existem casos realmente difíceis e que, para os quais, deve existir um abrigo preparado para sua moradia definitiva até a maioridade.

${ }^{38}$ Com algumas exceções: "Apesar do tempo de abrigamento poder ser associado à realização de um trabalho competente e articulado por parte do abrigo, para alguma conclusão a respeito, é necessário considerar a particularidade tanto da instituição como dos que nela vivem, pois certamente se nesses abrigos houver concentração maior daqueles que não têm família não será possível estabelecer a correlação inversa" (AASPTJSP/NCA-PUCSP/SAS/FUNDAÇÃO ORSA, 2003, p. 221).
} 
Para o profissional, a resposta a essa pergunta é óbvia: uma vez que se trabalha naquele local, nada mais natural do que retornar no dia seguinte. No início, pode-se pensar que o despropósito da pergunta pode estar relacionado ao fato, aliás, pouco provável, da criança não conhecer os regimes de trabalho. Ela se confunde e por isso pergunta se o funcionário retornará no dia seguinte. Contudo, conforme os dias passam e a pergunta insiste, surge a dúvida de que talvez ela seja motivada por outras questões. Semanas depois de se ter entrado e saído no mesmo horário, é impossível que a criança desconheça se amanhã é ou não o dia de trabalho daquele funcionário. E, no entanto, mais uma vez: "Tio, você volta amanhã?”. Começa-se a dar conta de que a insegurança sentida toda vez que alguém vai embora é real, ainda que seja para retornar no dia seguinte. Se a criança, apesar da força do hábito, não tem a segurança de que esse retorno irá realmente se concretizar no dia seguinte, é porque esse medo deve possuir raízes profundas.

Nossa hipótese é que crianças e adolescentes que passaram pela experiência do abandono desenvolvem uma insegurança fundamental em relação a todos os novos vínculos que ela constitui. Isso acontece porque os vínculos estruturantes de sua personalidade e que supostamente deveriam ser os mais estáveis ou pelo menos os mais duradouros de sua vida, não se constituíram a ponto de fornecer ao sujeito a segurança afetiva advinda do sentimento de pertença, cuidado e proteção que os vínculos parentais deveriam idealmente prover.

Aquele que passou pelo trauma do abandono desenvolve-se como uma construção que não possui as fundações muito sólidas, afinal, sua base não se constituiu plenamente.

Desse modo, conforme esse sujeito cresce, todo novo vínculo desperta nele o medo de que o destino dessa nova relação seja o mesmo que a de sua relação fundamental. É que chamamos de medo de re-atualização do abandono e se constitui em uma das mais importantes características da psicologia dos meninos e meninas que vivem em abrigos e é, muitas vezes, um dos melhores fatores explicativos para muitos de seus comportamentos que nos parecem incompreensíveis à primeira vista.

D. é um menino de dez anos que a quatro vive em abrigos. Ele foi abandonado pela mãe aos três anos, morou com uma tia até os seis, quando foi novamente abandonado e encaminhado ao abrigo. Ele possui muitas marcas pelo corpo que não o deixam esquecer a época em que apanhava constantemente daqueles com quem ele morava.

Apesar das tentativas de contato feitas pelo abrigo, todos os seus familiares mudaramse de estado, regressando ao Nordeste, região de origem da família, deixando para trás o pequeno D. Quando se esgotaram todas as tentativas no sentido de encontrar o paradeiro de seus parentes, foi pedida a destituição de poder familiar. Por volta dos 8 anos, D. tinha 
situação legal definida que o colocava disponível para adoção. No entanto, além de pertencente ao sexo masculino e um pouco velho para os padrões normalmente procurados pela maioria dos adotantes, D. era negro. Reunia, assim, todas as condições para permanecer no abrigo até os 18 anos, situação da qual ele estava ciente e que muito o entristecia.

Entretanto, certa vez, veio até o abrigo uma senhora que desejava trabalhar como voluntária na instituição, ministrando aulas de reforço escolar. D. já tinha 11 anos e passou a frequentar suas aulas, pois ia um pouco mal na escola. A senhora logo começou a demonstrar um carinho especial pelo garoto. A relação dos dois foi se desenvolvendo. Foi quando, pela primeira vez em muitos anos, D. passou as festas de final de ano no seio de uma família. $\mathrm{O}$ marido da senhora conheceu o menino e também se apaixonou. O casal foi amadurecendo a ideia de adoção e nos meses seguintes, D. começou a passar os finais de semana na casa daquela que, ao que parecia, seria sua nova família.

Foi feito o pedido oficial de adoção e D. foi chamado para uma entrevista com a psicóloga da Vara da Infância e Juventude. Tudo corria bem. Foi perguntado se D. gostava do casal em questão e ele respondeu afirmativamente. Foi perguntado ainda como eram os finais de semana em companhia do casal e se ele gostava dos períodos que passava com eles. Tudo certo. Foi então o momento em que D. foi indagado a respeito de se gostaria de morar em definitivo na casa do casal. D. hesitou. Não soube o que responder. Disse que sentiria falta dos educadores e dos colegas do abrigo. A psicóloga da Vara considerou muito estranha a resposta do menino. Ele parecia alguém que caminha sedento pelo deserto e que, ao ver um copo de água não o toma. Ela então decidiu postergar o encaminhamento do pedido final de adoção ao Juiz e pediu mais uma conversa com os pais e o garoto.

De fato, nenhuma justificativa no âmbito racional poderia explicar a resposta do menino. Ele gostava do casal e sabia que o sentimento era recíproco. Além disso, sabia que essa era provavelmente sua única chance de constituir novamente uma família. Por que então ele hesitou?

Segundo a interpretação desta análise, D. realmente não estava envolvido com questões da ordem da razão. Ele já havia sido abandonado duas vezes. Quem lhe garantia que daquela vez as coisas seriam diferentes? Como poderia saber se não seria abandonado novamente? E será que aguentaria ser esquecido pela terceira vez? Em outras palavras, com a proximidade da definição do processo de adoção, o medo da re-atualização do abandono veio à tona com toda a força e se expressava na postura hesitante do menino. 
Obviamente, na data marcada para a nova entrevista na Vara da Infância, D. afirmou que não desejava ser adotado naquele momento e preferia deixar as coisas como estavam: morando no abrigo e frequentando a casa do casal aos finais de semana.

Novamente a psicóloga considerou muito estranha a resposta do garoto e ponderou que, mesmo sem saber exatamente o que seria, deveria haver algo que estava atravancando o processo de adoção. Conversou com o casal e os informou que elaboraria um relatório informando ao Juiz as intervenções que foram feitas, as respostas do garoto e que sua opinião seria contrária à continuidade do processo de adoção. No mesmo momento, o casal, totalmente frustrado e decepcionado, e também acreditando cegamente na profissional, desistiu da adoção.

Por não compreender o mecanismo de reatualização do abandono pelo qual D. estava passando, pode-se considerar que a psicóloga se precipitou em elaborar um parecer contra a adoção. Na verdade, D. só estava pedindo mais um tempo. Naquele momento, o menino estava optando pela única instituição que, durante toda a sua vida, havia lhe proporcionado cuidado e proteção: o abrigo. Como esperar que em poucos meses D. escolhesse trocar o lugar que durante anos havia sido o seu porto seguro? A psicóloga e o casal não souberam esperar o tempo do garoto. Devido a uma enorme insegurança em relação a novos vínculos herdada de seu passado, D. hesitava como um mecanismo de defesa contra novas desilusões. Ao invés de desistir, de submeter D. a um novo abandono, a prova que o menino precisava para se entregar plenamente ao novo vínculo era que o casal e as instituições com poder de decisão sobre sua vida entregassem-se primeiro ao vínculo incondicional com ele, como deve ser o vínculo de toda mãe e de todo pai. O remédio contra a hesitação de D. era a insistência no vínculo e não o seu rompimento precoce. Era preciso apostar na permanência da relação, um investimento "no escuro" que, aparentemente, nem o casal nem a Vara da Infância e Juventude estavam dispostos a fazer.

O relato desse caso fornece um bom exemplo do medo de re-atualização do abandono em operação. Também ele levará este estudo ao próximo conceito que se pretende introduzir na tentativa de compreensão do universo mental de crianças e adolescentes abrigados: o "teste de vínculos". Como eles viveram um processo de rompimento de vínculos muito fundamentais e estruturantes como os vínculos parentais, passam a colocar à prova todos os demais vínculos que se tenta construir com eles. É o medo de que o abandono aconteça novamente que alimenta o teste de vínculos.

Os modos como esse teste pode ser realizado variam enormemente. Um dos exemplos que será citado é a postura reticente de D. O garoto, com sua hesitação, estava testando o 
vínculo com o casal que pretendia adotá-lo. Era a maneira que ele, inconscientemente, encontrou para certificar-se se o sentimento que o casal dizia nutrir por ele era mesmo forte e sólido.

Mas, talvez, a maneira mais comum utilizada por crianças e adolescentes para o teste de vínculos seja a agressividade. Para vincular-se com eles é preciso suportar suas reações agressivas iniciais, que visam testar se o candidato ao vínculo está investindo fortemente na relação ou não. O teste de vínculo é, na realidade, uma tentativa de prever a durabilidade e a permanência do vínculo por meio de sua força inicial. O trabalho de construção de vínculos com essa população é, eminentemente, um trabalho de insistência e persistência. É a constante disponibilidade para o vínculo (característica fundamental para todo educador de abrigos) que deve passar para a criança ou o adolescente abrigado a mensagem simbólica de aceitação de quem ele é e, principalmente, de segurança afetiva.

Toda vez que se convidei alguém a visitar os abrigos em que trabalhei, costumava alertar: "Não se assuste; eles podem te tratar muito mal no início!". É o teste de vínculos. Suas histórias de vida foram indelevelmente marcadas por uma rotatividade imensa de pessoas. Suas figuras de referência entravam e saíam de suas vidas com uma rotatividade angustiante. Nessa linha, considera-se ser totalmente esperado que essas crianças e adolescentes desenvolvam uma desconfiança em relação às novas pessoas que pretendem entrar em suas vidas, pois é preciso saber se essa nova relação que desponta é daquelas que vem e vão ou se é daquelas que permanecem.

Vale ressaltar que tal interpretação de certos aspectos da dinâmica psíquica de crianças e adolescentes abrigados é oposta àquela que se poderia denominar de "discurso do amor", extremamente difundida entre os trabalhadores da área social. Tal concepção propaga que basta muito carinho e afeto para conquistar o vínculo com essas crianças e adolescentes. Partindo do pressuposto de que eles seriam todos carentes, esse discurso baseia-se na concepção de que é preciso dar em excesso um amor que antes lhes faltava, em uma espécie de compensação do afeto negado no passado. A característica psicológica fundamental dessa população não seria o medo de re-atualização do abandono, como se vem tentando argumentar, mas sim uma grande carência afetiva. O abrigado seria então uma espécie de "poço sem fundo" em sua necessidade de receber afeto.

O que não se percebe é que essa demanda não está à procura de uma grande quantidade de afeto, procuram sua solidez e, principalmente, sua constância no tempo. Esses meninos e meninas não estão interessados na quantidade, mas sim na qualidade do amor que lhes é dado. Uma grande, mas curta carga de afeto (como quando voluntários organizam 
enormes festas de natal, cheias de presentes para as crianças e depois não aparecem mais até o ano seguinte) pode simplesmente lembrar as crianças e adolescentes abrigados daquilo que lhes falta. É como uma vitrine com objetos que se deseja muito, mas que não se pode comprar devido ao seu elevado preço. Em suas vidas marcadas pela instabilidade, essa população não procura um amor grande. Procura um amor estável. A constância do amor investido é a principal característica para aquele que pretende desenvolver uma relação afetiva com essas crianças e adolescentes.

Entende-se que essas informações são preciosas para os educadores e monitores dos abrigos, pois o principal objetivo de seu trabalho é justamente o de se vincular com esses meninos e meninas para que estes então permitam serem cuidados e ajudados. A relação de cuidado e ajuda é sempre uma via de mão dupla: não basta a intenção de cuidar ou ajudar. Essa é uma visão ingênua do processo. É preciso que haja permissão para que esse cuidado ou ajuda ocorra. E a construção do vínculo é simplesmente a condição de possibilidade para essa permissão. É nesse sentido que o educador de abrigo poderia ser descrito, em essência, como um "profissional do vínculo". Tem a difícil atribuição de construir uma relação afetiva com a criança e o adolescente abrigado, diferente de todas as outras que eles já experimentaram. Tem a tarefa de mostrar que vínculos estáveis e duradouros são possíveis, tentando desconstruir esse mecanismo quase automático de colocar à prova toda nova tentativa de aproximação. Espera-se que o vínculo com o educador seja aquele que irá propiciar não a reatualização do abandono, mas a re-elaboração dos vínculos traumáticos instalados profundamente no passado desses meninos e meninas.

\subsubsection{As famílias das crianças e adolescentes abrigados}

É no PNCFC (2006) que se pode encontrar os maiores desenvolvimentos, em termos de documentação oficial, a respeito das diretrizes conceituais e dos princípios metodológicos básicos a respeito do modo como se deve tratar a temática da família no contexto das políticas públicas de atendimento à infância e à adolescência. O modo como as leis e os marcos regulatórios compreendem a noção de família e, mais especificamente, as famílias que possuem seus filhos em situação de abrigamento, é ponto essencial a ser apresentado no presente estudo. Caso contrário, correr-se-ia o risco de incidir nas críticas apresentadas nesse 
mesmo trabalho a respeito da necessidade de não compreender a criança ou o adolescente abrigado de modo isolado, ou seja, apartado de seu contexto, que é a família.

Além disso, não se poderia deixar de apontar que o PNCFC tem o mérito de se constituir em uma política de Estado, ao invés de uma política de governo, pois prevê ações para o período de 2007 a 2015. Esse é um grande avanço em termos de formulação de políticas públicas, uma vez que tenta escapar das disputas político-partidárias.

Segundo o PNCFC, “a legislação brasileira reconhece e preconiza a família, enquanto estrutura vital, lugar essencial à humanização e à socialização da criança e adolescente, espaço ideal e privilegiado para o desenvolvimento integral dos indivíduos" (2006, p. 15). Iniciando a temática que irá se desenvolver por todo o documento, o PNCFC aponta a família como espaço privilegiado para a socialização dos sujeitos o que, por si só, já representa uma tomada de posição contra a institucionalização.

Contudo, o PNCFC coloca que esse não foi o direcionamento das políticas estatais ao longo de nossa história. "O reconhecimento dado à relevância da convivência familiar no estatuto legal contrasta, entretanto, com o grande número de crianças e adolescentes abrigados" (FÁVERO, VITALE \& BAPTISTA, 2008, p. 19).

O Estado traduzia as dificuldades encontradas pelos pais para criarem seus filhos em uma pretensa "incapacidade" inerente às famílias, especialmente às famílias pobres, abdicando ideologicamente da análise do contexto socioeconômico no qual elas estavam inseridas, escondendo, assim, as suas próprias responsabilidades.

Ao longo de muitas décadas, esse foi o argumento ideológico que possibilitou ao Poder Público o desenvolvimento de políticas paternalistas voltadas para o controle e a contenção social, principalmente para a população mais pobre, com total descaso pela preservação de seus vínculos familiares. (PNCFC, 2006, p. 15)

Com uma política voltada para o controle e a contenção social, ao invés da proteção, “essa desqualificação das famílias em situação de pobreza, tratadas como incapazes, deu sustentação ideológica à prática recorrente da suspensão provisória do poder familiar ou da destituição dos pais e seus deveres em relação aos filhos" (2006, p. 15).

Pelo simples fato de ser pobre, uma criança ou adolescente estava sujeito a ser confinado em grandes instituições totais, sob o argumento de "prender para proteger". A criança e o adolescente pobre, assim como o louco ou o leproso, estava constantemente sob a mira de políticas higienistas cujo objetivo era "limpá-los" das ruas, escondê-los para que não se visse aquilo que a sociedade queria esquecer. Tal como os manicômios e leprosários, os 
orfanatos foram durante muito tempo a resposta que o poder instituído tinha para as questões que envolviam família, infância e adolescência em situação de pobreza.

Apenas recentemente uma mudança nessa visão começou a ser construída. O coroamento dessas transformações aconteceu com a promulgação, além da Constituição Federal de 1988, também do ECA, em 1990, da LOAS, e, em 1993, com a ratificação da Convenção sobre os Direitos da Criança, em 1990. Como um resumo das indicações que constam nessas leis, poder-se-ia levantar os seguintes pontos, fundamentais nessa mudança de paradigmas: concepção das crianças e dos adolescentes como sujeitos de direitos, concepção da família de modo indissociável de seu contexto socioeconômico, concepção da família como lugar essencial da socialização e, mais concretamente, a proibição da institucionalização tendo a pobreza como motivo.

Quanto a esse último, o PNCFC é explícito:

É importante destacar que a situação de pobreza não constitui motivo suficiente para o afastamento familiar e institucionalização da criança e do adolescente - Art. 23 do ECA - nem a presença de uma deficiência, transtorno mental ou outros agravos. Nas situações de pobreza, conforme previsto na legislação, a família deverá obrigatoriamente ser inserida em programas sociais de auxílio. (2006, p. 71)

A Constituição Federal estabeleceu que a família é a base da sociedade (art. 226) e que, portanto, compete a ela, juntamente com o Estado e a sociedade em geral, assegurar à criança e ao adolescente o exercício de seus direitos fundamentais (art. 227), dentre os quais se encontra o direito à convivência familiar e comunitária. De "incapaz", a família transforma-se, além de capaz, no principal meio de promoção e garantia dos direitos de seus filhos. E é por isso que, se historicamente a noção de incapacidade das famílias pobres forjou a justificativa ideológica para a desresponsabilização do Estado na garantia de seus diretos, a Carta Constitucional, em seu art. $226 \S 8$, invertendo essa lógica, estabelece ao Estado o dever de assegurar assistência à família na pessoa de cada um dos que a integram, criando mecanismos para coibir violências no âmbito de suas relações.

Pode-se dizer que a ideia é primar para que "o direito da criança e do adolescente à convivência familiar e comunitária se efetive em consonância com a garantia de direitos sociais à sua família de origem - para que de fato esta possa proteger seus filhos" (FÁVERO, 2007).

A Constituição Brasileira de 1988 define no art. 226, parágrafo 4: "entende-se como entidade familiar a comunidade formada por qualquer um dos pais e seus descendentes". O 
ECA também segue na mesma linha e define família, em seu art. 25, “a comunidade formada pelos pais ou qualquer deles e seus descendentes".

Segundo o PNCFC,

[...] essas definições colocam a ênfase na existência de vínculos de filiação legal, de origem natural ou adotiva, independentemente do tipo de arranjo familiar onde esta relação de parentalidade e filiação estiver inserida. Em outras palavras, não importa se a família é do tipo "nuclear", "monoparental”, reconstituída ou outras. (2006, p. 23)

A abrangência da atual definição legal de família imprimiu grande flexibilidade na compreensão do que é a instituição familiar. Para o PNCFC "torna-se necessário desmistificar a idealização de uma dada estrutura familiar como sendo a 'natural', abrindo-se caminho para o reconhecimento da diversidade das organizações familiares no contexto histórico, social e cultural” (2006, p. 23). A ênfase não deve recair mais sobre a estrutura familiar, mas sim sobre a capacidade da família, em qualquer uma de suas formas, de exercer a sua função de proteção e socialização, ou seja, a estrutura familiar não determina a capacidade de cada família de cuidar de seus filhos. Essa capacidade passa a ser concebida como um atributo capaz de se desenvolver em uma diversidade de arranjos e não mais em uma única estrutura fixa e ideal.

Quanto a essa questão, o PNCFC levanta alguns dados concretos, retirados da Pesquisa Nacional por Amostra de Domicílios de 2004, que ajudam a visualizar essa realidade: $9,9 \%$ das famílias são unipessoais, ou seja, compostas por uma única pessoa; 14,4\% eram casais sem filhos; $51,5 \%$ formavam casais com filhos e 18,1\% eram mulheres com filhos, mas sem cônjuges.

Recalculando os percentuais apenas para aquelas famílias que têm crianças e adolescentes - ou seja, retirando as unidades domiciliares com uma pessoa, casais sem filhos e outros tipos - pode-se ver que $25 \%$ das famílias são monoparentais e, se em $75 \%$ há um casal com filhos, isso não indica se o cônjuge da mãe é o pai das crianças. Ou seja, há um grande percentual de crianças e adolescentes vivendo em famílias cuja forma de organização não responde à idealização feita de uma família de pai, mãe e seus filhos em comum. (PNCFC, 2006, p. 52)

Dentre as famílias que possuem crianças e adolescentes abrigados apenas $31 \%$ são de casais casados ou em união estável (FÁVERO, VITALE \& BAPTISTA, 2008, p. 48). Desse modo, comprova-se o óbvio: que a maioria dessas famílias não possui o modelo nuclear como padrão. 
No entanto, pode-se constatar que em $88 \%$ dos casos o número de pessoas morando no mesmo domicílio não ultrapassa quatro pessoas (FÁVERO, VITALE \& BAPTISTA, 2008, p. 61). Isso significa que o mito de que as famílias de crianças e adolescentes abrigados ou simplesmente famílias pobres são sempre muito numerosas é algo que necessita ser questionado e incorporado às metodologias de trabalho com essa população. Esse é um exemplo das costumeiras generalizações que se costuma fazer a respeito das famílias que possuem crianças e adolescentes abrigados e que têm como efeito a estigmatização dessa população.

Parece ser possível afirmar também que dentre essas que se aproximam do modelo idealizado, a maioria (52\%) é de formação relativamente recente - menos de 5 anos (FÁVERO, VITALE \& BAPTISTA, 2008, p. 57). Em termos estatísticos parece ser possível afirmar que filhos de casais jovens têm mais chance de serem abrigados do que filhos de casais que compartilham uma união de mais longa data.

Dentre essas mudanças, um dos destaques foi o aumento do número de famílias cuja pessoa de referência é a mulher que, de 1993 a 2003, aumentou de 22,3\% para 28,8\%.

$\mathrm{Na}$ população geral, apesar do aumento percebido no número de mulheres como chefes de família, os homens continuam como referência para aproximadamente $70 \%$ delas. Nas famílias que possuem crianças e adolescentes abrigados, essa configuração se inverte. De acordo com Fávero, Vitale e Baptista (2008) a mãe é a pessoa de referência para $62 \%$ das crianças e adolescentes abrigados, sendo o pai a referência para apenas $16 \%$ deles (p. 30). Essa inversão está longe de revelar mulheres emancipadas e com capacidade de sustentar e prover sua família autonomamente. Ao contrário, revela mulheres abandonadas.

De fato, é a mãe que costuma expressar o desejo de manter os vínculos com o filho abrigado, inclusive sendo ela a figura mais frequente nas visitas aos abrigos e, consequentemente, com quem as equipes dos abrigos têm mais contato e possibilidades de trabalho.

"Também se deve atentar para o fato de que nenhuma das crianças/adolescentes acolhidas aparece como tendo ambos os pais como seus responsáveis perante a unidade de abrigamento" (FÁVERO, VITALE \& BAPTISTA, 2008, p. 30). Isso significa ser possível afirmar que, estatisticamente, a ausência de um dos genitores aumenta a chance de uma criança ou adolescente ser abrigado em algum momento de sua vida, ou seja, a falta de um dos pais é fator de risco para seus filhos e se constitui em uma característica bastante frequente entre as famílias que possuem crianças ou adolescentes em abrigos. 
Mas, talvez, a principal característica dessas famílias seja a ausência da figura paterna. Ressalta-se que, em relação ao histórico familiar, "o maior destaque é a informação sobre o paradeiro desconhecido do pai” (AASPTJ-SP/NCA-PUCSP/SAS/FUNDAÇÃO ORSA, 2003, p. 179). Poder-se-ia citar, ainda, com o intuito de corroborar as afirmações acima, que $44 \%$ dos abrigados só possuem o nome da mãe em seu registro de nascimento (cf. AASPTJSP/NCA-PUCSP/SAS/FUNDAÇÃO ORSA, 2003, p. 171).

Segundo o estudo AASPTJ-SP/NCA-PUCSP/SAS/Fundação Orsa (2003), existe um destaque para as respostas que indicam mães solteiras (p. 178) na configuração familiar de crianças e adolescentes abrigados. Ou seja, mães cuidando sozinhas de seus filhos. Em relação aos pais, há destaque para os que convivem com a mãe dos abrigados (p. 178). O que se conclui é que, para os homens, não se coloca tanto essa questão de criar os filhos sozinhos, sendo este um fardo que a sociedade parece ter reservado às mulheres.

O homem, de forma geral, parece ser pouco cobrado a respeito de seus deveres e obrigações relacionados à geração e à proteção dos filhos. A questão de gênero revela-se nessa realidade, evidenciada pela continuidade da responsabilidade da mulher pelos cuidados das crianças, muitas vezes acompanhada da responsabilidade de provimento material da família. (FÁVERO, VITALE \& BAPTISTA, 2008, p. 30)

Percebe-se nesses dados um latente preconceito de gênero, também perceptível na presença maciça de mulheres como educadoras dos abrigos, como se o encargo da educação dos pequenos fosse tarefa naturalmente feminina, reproduzindo dentro dessas instituições tal lógica machista. Fávero, Vitale e Baptista (2008) apontam que 78\% de seus entrevistados eram do sexo feminino. Tanto o abrigo como a família dos abrigados são ambientes eminentemente femininos.

Autores como Sarti (1996), por exemplo, têm relacionado essa situação à histórica função do homem como provedor, ou seja, abandonar sua família teria uma vinculação íntima com sua incapacidade de sustentá-la. Caso ele perca esse lugar, ele foge como se tivesse perdido o lugar na própria família já que, no interior dessa lógica, um homem vale tanto quanto consegue prover sua família. Essa concepção costuma ser tão arraigada em alguns casos que muitos pais chegam a demonstrarem-se ofendidos quando perguntados se a família recebe algum tipo de auxílio financeiro de programas de assistência social, como se estes questionassem o seu papel de provedor.

Apesar de este trabalho concordar com essa explicação, a análise dos dados trazidos pelo estudo de Fávero, Vitale e Baptista (2008) podem indicar outro caminho, como 
explicação complementar. Curiosamente, a sensação de desresponsabilização masculina no cuidado com os filhos se expande inclusive para todo o ramo paterno, inclusive suas mulheres. É o que revela a pesquisa supracitada quando expõe a porcentagem de que apenas 4\% das pessoas de referência das crianças e adolescentes abrigados são da família extensa por parte do ramo paterno, enquanto que, em relação ao materno, o índice é de 14\% (cf. p. 30). "Verifica-se que a mãe permanece como referência central na manutenção dos vínculos com os filhos, e que sua família de origem parece assumir também esse papel enquanto alternativa à ausência do pai e de outros familiares" (FÁVERO, VITALE \& BAPTISTA, 2008, p. 30).

Além de situar o homem como provedor, não se espera dele afeto e cuidados para com seus filhos. O sustento seria sua única responsabilidade, ficando as funções de acompanhamento do crescimento das crianças a cargo exclusivo da mulher. Isso revela que a educação dos filhos é concebida socialmente como uma função "natural" da mulher, a ponto de quando o pai falta, seu ramo familiar não se sente na obrigação de se implicar e colaborar com a criação dessas crianças.

Como complemento às considerações que relacionam o abandono paterno com sua situação empregatícia e, consequentemente, à sua capacidade de prover, está o cuidado com os pequenos concebido como papel "naturalmente" feminino. São ambos os lados do abandono paterno: por ter sido socializado em uma cultura machista que não vê com bons olhos o homem que se engaja em cuidados com seus filhos é que este homem, quando perde seu lugar de provedor, foge da família como se fosse um membro impossibilitado de assumir quaisquer outras tarefas, mesmo que por um período de tempo reduzido.

Tais considerações são de extrema relevância como orientação para o trabalho de reintegração familiar nos abrigos, pois, apesar de maior acessibilidade às mães, não se pode abdicar da tentativa de se trabalhar com os pais no sentido do resgate de seus vínculos e obrigações para com seus filhos. O PNCFC faz uma importante consideração a esse respeito, apontando para a necessidade de

[...] se estimular o envolvimento da figura paterna na vida de crianças e adolescentes, uma vez que na grande maioria das famílias monoparentais é o pai que não mora no domicílio - o que não significa, necessariamente, que tenha perdido o vínculo com os filhos e muito menos que escape à responsabilização de suas funções paternas. (2006, p. 24)

Mesmo afastado do lar, mesmo impossibilitado de colaborar com o provimento material de seus filhos, tais obstáculos não significam que se deve desistir de investir na recuperação de suas funções como pai. E, mesmo quando esse trabalho se mostrar impossível, 
não se pode esquecer que a responsabilização judicial daquele que abandona é, na maioria dos casos, vivida com uma sensação de justiça por parte dos que foram abandonados. Apesar da constante tentativa de superar a dicotomia paralisante entre agressor e vítima nos casos que envolvem violência, são as crianças e os adolescentes que possuem prioridade absoluta garantida em lei. Não se deve nunca deixar de ter claro quem é o adulto da relação, ou seja, quem, além de possuir direitos, possui também muito mais responsabilidades que seus filhos e que deve responder por elas de modo mais assertivo.

Outro apontamento levantado pela pesquisa da AASPTJ-SP/NCAPUCSP/SAS/Fundação Orsa (2003) foi a constatação de uma quantidade relevante, embora não se tenha a porcentagem, de crianças e adolescentes abrigados cujos irmãos mantiveram a convivência em meio familiar, tanto junto com outros familiares quanto com a própria família de origem (p. 191).

A pesquisa de Fávero, Vitale e Baptista (2008) é mais específica, apontando que $48 \%$ das famílias que entrevistaram possuíam filhos vivendo com eles enquanto outros permaneciam abrigados (p. 64).

A partir desse quadro, impõem-se a pergunta sobre as razões que conduzem alguns dos filhos de uma família a viverem separados dela, enquanto outros permanecem em seu convívio. Será que alguns sofrem mais violência a ponto de necessitarem de abrigamento, enquanto outros não?

Uma das pesquisas que levantaram o questionamento infere "a existência de motivos relacionados à própria família, mas também os de ordem institucional que podem estar reproduzindo tal situação" (AASPTJ-SP/NCA-PUCSP/SAS/FUNDAÇÃO ORSA, 2003, p. 191). Quanto aos motivos de ordem institucional, considerou-se as situações em que a rede de proteção efetivamente tenha falhado ou, ainda, errado na sua avaliação da dinâmica familiar, e que o correto seria que ambos os irmãos estivessem abrigados, imaginando-se que aquele que permaneceu na família continua sofrendo violência.

Nesse âmbito, é importante indagar

[...] que critérios utiliza o Estado, por meio do Poder Judiciário ou de outra instância do sistema de garantia de direitos, para definir como uma mesma família tem condições de cuidar de alguns de seus filhos e de outros não. (FÁVERO, VITALE \& BAPTISTA, 2008, p. 108)

No entanto, existem configurações familiares em que somente um dos filhos é vítima de violência. Por que isso ocorre? Tal pergunta exigiria um estudo mais aprofundado da 
psicodinâmica das famílias agressivas, o que foge do escopo deste trabalho. Apesar disso, pode-se apontar, ainda que sucintamente, algo que possa auxiliar na compreensão desse fenômeno e que se tem percebido, em experiência pessoal de trabalho com essa população, como um mecanismo bastante característico das famílias agressoras. Trata-se de algo que se poderia chamar de "individualização das culpas" ou simplesmente, como é mais costumeiramente conhecido, de "bode expiatório". Poder-se-ia tentar esclarecer esse movimento que ocorre no interior dessas famílias (mas não somente delas) como um mecanismo de que seus membros lançam mão na tentativa de mitigar suas angústias e sofrimentos, por meio da concentração ilusória desses aspectos negativos em torno de uma única pessoa, que passa a ser responsabilizada por eles e, muitas vezes, agredida como forma de expiação de sua suposta culpa. Trata-se de achar um culpado pela "desgraça" familiar, por meio de movimento de desresponsabilização.

Nesses casos, o abrigamento do "bode expiatório" é carregado de ambiguidades. Por um lado, tende a gerar a sensação de que quem foi separado da família era realmente o culpado por todo o sofrimento da mesma. O abrigamento "confirma" ilusoriamente o movimento de "individualização da culpa" produzido pelo núcleo familiar para se defender do fato angustiante de que as razões de seu sofrimento não podem ser concentradas em um único indivíduo. Ao contrário, eles costumam ser de responsabilidade coletiva.

Mas, por outro lado, o abrigamento pode, a partir de um bom trabalho psicossocial com essa família, ser o motor de uma reelaboração de suas relações afetivas, uma vez que o suposto responsável por todos os males não se encontra mais no convívio da família e, podese supor, esses males, de um modo ou de outro, continuarão a existir, mas agora sem alguém para culpar e eximir-se da responsabilidade. $\mathrm{O}$ abrigamento muda a psicodinâmica familiar e pode ser uma situação motivadora para se repensar antigas práticas familiares.

O estudo de Fávero, Vitale \& Baptista (2008) ainda aponta para outro mecanismo psíquico capaz de explicar o fato de existirem famílias com alguns filhos abrigados e outros não.

É possível que questões relativas a múltiplos casamentos também estejam presentes nessa definição. Aventa-se a possibilidade de que filhos do atual casamento estejam com os pais e outros de uniões anteriores e que já estavam abrigados permaneçam nessa condição após outra união da mãe. (p. 65)

Está-se diante de uma situação em que a mãe dá preferência ao atual companheiro em relação aos filhos que não teve com ele. É um mecanismo que coloca o laço conjugal acima 
dos laços de filiação. Parece que tal mecanismo pode ser vinculado a uma estratégia inconsciente ligada, por exemplo, à questão da sobrevivência: uma mulher encontra no novo companheiro uma possibilidade de apoio e suporte e passa a, inconscientemente, renegar, mantendo no abrigo, aqueles filhos que poderiam trazer conflitos para o novo relacionamento.

Em resumo, a existência de crianças e adolescentes abrigados que possuem irmãos que permanecem com seus familiares sugere "a ocorrência de uma prática eletiva no abrigamento, que pode ocorrer tanto no âmbito familiar quanto por parte das instituições responsáveis pelo cumprimento da medida" (AASPTJ-SP/NCA-PUCSP/SAS/FUNDAÇÃO ORSA, 2003, p. 213).

O estudo das famílias de crianças e adolescentes abrigados revelou que suas histórias de institucionalização possuem ramos que se estendem para além deles próprios.

De acordo com os dados coletados, o acolhimento institucional já ocorreu com alguns sujeitos da pesquisa e com parentes da geração anterior, assim como a transferência da responsabilidade dos cuidados e da proteção dos filhos para outras famílias. (FÁVERO, VITALE \& BAPTISTA, 2008, p. 42)

Desse modo, parece que, em algumas ocasiões, o abrigamento deve ser entendido como um fenômeno transgeracional, ou seja, como um sintoma que se repete. Supõe-se que, nessas famílias com histórico de institucionalização em vários de seus membros, o processo de desresponsabilização dos pais por seus filhos se acentue ou mesmo se naturalize. O abandono passa a ser algo esperado. "É comum o indivíduo reproduzir o que lhe é mais familiar: se uma das estratégias para sua sobrevivência foi a institucionalização, é possível que ele recorra a ela para o cuidado de seus filhos, e assim sucessivamente" (FÁVERO, VITALE \& BAPTISTA, 2008, p. 108).

O abrigo se transforma em parte da herança familiar no sentido de uma prática e de um valor (o da desresponsabilização) que se passa de pai para filho. Assim, quando se evita o abrigamento de uma criança ou adolescente, se está fazendo muito mais do que garantir o direito à convivência familiar e comunitária daqueles que estão envolvidos imediatamente na situação. Na realidade, ao evitar um abrigamento, posiciona-se contra uma história de institucionalização que pode remontar a muitas gerações, interrompendo um ciclo perverso de abandono que se reproduzia de pai para filho. Em outras palavras, o abrigamento pode ser concebido como uma herança, mas não como uma maldição familiar.

A relação entre o tempo médio de internação de pais e filhos revela, no entanto, alguns avanços na política de abrigamento. Afirmou-se anteriormente que a porcentagem de crianças 
e adolescentes abrigados por um período superior a dois anos era de 52,9\% (cf. AASPTJSP/NCA-PUCSP/SAS/Fundação Orsa, 2003, p. 187). Segundo Fávero, Vitale e Baptista (2008), esse número na geração de pais dos abrigados chega a 67\%, sendo que a faixa de maior concentração é a que varia de 9 a 12 anos, com 34\% do total (p. 68). Segundo o Levantamento Nacional, a faixa de maior concentração de crianças e adolescentes no Brasil segundo o tempo de abrigamento é a de dois a cinco anos (32,9\%) (cf. IPEA, 2003, p. 4).

Ainda que esses percentuais em relação às crianças e adolescentes estejam elevados, quando comparados com os dados existentes a respeito de uma geração anterior de abrigados, percebe-se que o tempo médio de abrigamento diminuiu, indicando algum avanço no combate à "cultura de institucionalização" historicamente presente no Brasil e ainda tão influente até hoje.

Ainda como característica das famílias que possuem filhos abrigados, a pesquisa de Fávero, Vitale e Baptista (2008) aponta para sua

[...] imensa capacidade de resiliência e, ao falarem de suas crianças e adolescentes, várias destacam que a institucionalização é algo "bom", na medida em que possibilita melhores condições de desenvolvimento do que suas crianças e adolescentes teriam no ambiente familiar. Todavia, como parte desse movimento, deixam claro, em sua quase totalidade, que têm como desejo o retorno deles para casa, o qual, via de regra, fica condicionado ao acesso aos direitos sociais básicos, entre eles o trabalho, a moradia e a escola. (p. 27)

Frente às situações de gritante pobreza, parece bastante claro que essas famílias encontrarão nos abrigos uma possibilidade de propiciar a seus filhos algo que elas próprias não teriam condições de fazê-lo. No entanto, este autor não tem certeza se concorda com as autoras quando estas interpretam esse fato como "resiliência", ou seja, como a capacidade de superar os obstáculos, de transformar problemas em soluções.

Sem querer negar que tais famílias são capazes de superação, de nosso ponto de vista, as famílias de crianças e adolescentes abrigados consideram a institucionalização de seus filhos como algo "bom" por dois motivos complementares e não excludentes: em primeiro lugar, essa "positividade" é um modo de negação da violência intrafamiliar. Como uma espécie de formação reativa, somente os aspectos positivos do abrigamento são destacados na tentativa de obliterar a sua motivação: a violência dos pais para com seus filhos, cuja culpa, provavelmente, estes estão tentando mitigar. Em segundo lugar, essas famílias parecem vítimas de um processo segundo o qual a pobreza "força-as" a relegarem a dimensão afetiva da convivência entre pais e filhos a um segundo plano, já que necessitam manter como foco 
de sua atenção e disposição de energias a questão da sobrevivência. Nesse ponto, é digna de nota a informação de que $24 \%$ das famílias consideram o abrigamento algo bom, pois seus filhos "têm onde morar e se alimentar" (FÁVERO, VITALE \& BAPTISTA, 2008, p. 37).

Note-se, ainda, que estas famílias se comportam como se elas próprias não fizessem falta na vida dos filhos quando estes têm sua subsistência garantida por outros meios. É o que se pode depreender de falas colhidas por Fávero, Vitale e Baptista (2008), que consideram a institucionalização algo positivo porque "os filhos estão bem cuidados" ou porque no abrigo "os filhos são bem educados" (p. 119). Nessas respostas fica claro que a própria família incorpora a ideologia que a concebe como incapaz de cuidar e educar seus próprios filhos, estabelecendo uma confusão entre a falta de recursos materiais e a falta de capacidade para educar os filhos.

A privação material instaura um mecanismo perverso que transforma a sobrevivência em um fim a ser alcançado, não importando quais os meios que se façam necessários. No caso concreto que se está analisando, essas famílias parecem viver o abrigamento de um de seus membros como o preço a se pagar para garantir as mínimas condições de vida a seus filhos, ainda que esse preço implique em abdicar de sua condição de pais naquilo em que isso implica em algo além do provimento material, ou seja, nas funções de cuidado, afeto, proteção e socialização.

De modo geral,

[...] a desnaturalização do conceito de família, a desmistificação de uma estrutura que se colocaria como ideal e, ainda, o deslocamento da ênfase da importância da estrutura familiar para a importância das funções familiares de cuidado e socialização, questionam a antiga concepção de "desestruturação familiar" quando abordamos famílias em seus diferentes arranjos cotidianos. (PNCFC, 2006, p. 29)

O discurso da "família desestruturada" é a re-atualização mais recente de séculos de preconceito calcados na noção de incapacidade das famílias pobres que, novamente, individualiza os conflitos sociais por meio da idealização da família nuclear como a única capaz de propiciar um desenvolvimento saudável.

Nesse sentido, ainda são muito comuns referências, especialmente em relação à figura materna, tais como: desestimulada, apática, acomodada, omissa etc. Essa situação não só acaba culpabilizando as famílias como também centraliza a culpa na figura feminina, reproduzindo preconceitos de gênero nessa questão. Essas palavras, presentes inclusive no 
discurso dos trabalhadores dos abrigos, devem ser consideradas muito menos características intrínsecas dessas famílias do que indicadores da incompreensão social em relação a elas.

Ao invés disso, a tônica proposta nos atuais marcos regulatórios das políticas públicas é a ênfase nas capacidades e potencialidades dessas famílias. É justamente por conceber a família como uma entidade em constante transformação que se torna possível

[...] compreender o investimento no fortalecimento e no resgate dos vínculos familiares em situação de vulnerabilidade, pois cada família, dentro de sua singularidade, é potencialmente capaz de se reorganizar diante de suas dificuldades e desafios, de maximizar as suas capacidades de transformar suas crenças e práticas para consolidar novas formas de relações. (PNCFC, 2006, p. 29)

Tal é a justificativa ética subjacente aos trabalhos psicossociais dirigidos às famílias das crianças e adolescentes institucionalizados pelas equipes dos abrigos. Na contramão do senso comum, que desvaloriza a capacidade de transformação dessas famílias, deve ser pressuposto da metodologia de intervenção familiar dos profissionais dos abrigos a certeza de que elas são capazes de mudança. Ao invés de se destacar as incapacidades, deve-se olhar para as potencialidades de cada família em particular.

A partir da constatação do direito de toda criança e adolescente a ter uma família como um direito fundamental, o direcionamento dado pelo PNCFC para as

[...] situações de risco e enfraquecimento dos vínculos familiares é que as estratégias de atendimento deverão esgotar as possibilidades de preservação dos mesmos, aliando o apoio sócio-econômico à elaboração de novas formas de interação e referências afetivas no grupo familiar. (2006, p. 15)

Em outras palavras, antes de se retirar a criança ou o adolescente do convívio familiar, deve-se esgotar todas as possibilidades possíveis de apoio para que esta família se reorganize sem perder o contato com os filhos. Ratificando a diretriz do ECA, separar pais e filhos deve ser sempre a última medida a ser tomada, somente quando todas as intervenções anteriores fracassaram.

No entanto, não é isso que tem revelado as pesquisas sobre abrigamento. Pode-se citar como exemplo um dado colhido por Fávero, Vitale e Baptista (2008), o qual indica que 78\% das famílias que possuíam filhos abrigados na cidade de São Paulo não tinham acesso a outros programas de assistência social. Ora, se essas famílias estão com seus filhos abrigados e não possuem acesso a demais programas de assistência social é porque o abrigamento foi, 
provavelmente, a primeira medida tomada para o enfretamento de suas situações de vulnerabilidade. Invertendo a lógica estabelecida pelo ECA, o sistema de proteção à criança e ao adolescente em situação de risco social funciona de ponta-cabeça: utiliza o último recurso como o primeiro. Nesse sentido, muitas das situações de calamidade que se encontram atualmente nos abrigos devem ser compreendidas a partir de uma visão amplificada para toda a rede de proteção, pois, em muitos casos, os abrigos estão absorvendo a demanda proveniente de falhas na proteção básica. Somente quando toda a rede de proteção funcionar é que os abrigos conseguirão realizar sua função com propriedade. Toda política de abrigamento tenderá ao mais absoluto fracasso se for utilizada como regra ao invés de exceção.

Os dados disponíveis a respeito da situação de trabalho desses familiares corroboram os apontamentos acima. Em um universo no qual 35\% desses familiares estão desempregados e apenas 12\% trabalham com vinculação formal ("com carteira assinada") (cf. FÁVERO, VITALE \& BAPTISTA, 2008, p. 80) evidenciando uma situação de total precarização do trabalho e exclusão do mercado formal de emprego, o familiar que "mantém o vínculo com a criança abrigada é aquele que geralmente exerce alguma atividade de trabalho (53\%), vindo, em seguida, a pessoa com quem convive - pai e/ou mãe da criança (23\%) (cf. FÁVERO, VITALE \& BAPTISTA, 2008, p. 85). Esse quadro permite-nos afirmar que uma situação de maior estabilidade no trabalho fortalece os vínculos afetivos no interior da família, prevenindo o abrigamento ou então ampliando as possibilidades de retorno à família. A segurança social proveniente da satisfação das necessidades mais elementares da vida é um fator essencial para que a vida familiar se desenvolva.

No caso das famílias pobres, essa diretriz se torna ainda mais importante dado que esta costuma registrar em sua história eventos bastante traumáticos,

[...] determinados pelas condições socioeconômicas e pela luta pela sobrevivência: migrações em busca de novas oportunidades; institucionalização de crianças, adolescentes, adultos e idosos; afastamento dos responsáveis por longos períodos em função da ocupação exercida. (PNCFC, 2006, p. 53)

É preciso entender a história de vida de cada família, frequentemente recheada de

[...] inúmeras rupturas (corte nas trajetórias educacionais, empregos instáveis, trabalhos precários, alterações de moradias, rompimentos relacionais e outros) capazes de gerar a saída (temporária ou definitiva) de 
seus membros mais jovens, como no dos abrigamentos de crianças e adolescentes. (FÁVERO, VITALE \& BAPTISTA, 2008, p. 17)

A vida dessas famílias traz as marcas da instabilidade. Nada permanece durante muito tempo: empregos, moradias, escolas e, no limite, os próprios vínculos familiares. O que se poderia chamar de "pulverização" dos membros da família também é uma característica que se pode perceber em muitas delas, ou seja, com cada membro morando em um lugar diferente, com uma pessoa diferente.

Além desses fatores ligados à pobreza, uma diversidade de outros motivos incorre para explicar a incidência da violência intrafamiliar contra crianças e adolescentes. O PNCFC destaca os seguintes:

[...] história familiar passada ou presente de violência doméstica; ocorrência de perturbações psicológicas entre os membros da família; o despreparo para a maternidade/paternidade de pais jovens, inexperientes ou sujeitos a uma gravidez indesejada; adoção de práticas educativas muito rígidas e autoritárias; o isolamento social das famílias que evitam desenvolver intimidade com pessoas de fora do pequeno círculo familiar. (2006, p. 54)

De modo sintético, o PNCFC recoloca o debate a respeito do porquê, afinal, essas famílias serem violentas. O importante aqui não é perceber o imperioso reducionismo do texto em relação às razões profundas do nascimento da violência em determinadas famílias. $\mathrm{O}$ essencial é lembrar que se trata de um marco regulatório, ou seja, um texto de política pública que, como tal, não tem a pretensão de esgotar os temas tratados, mas sim de estabelecer as diretrizes a partir das quais eles devem ser trabalhados. A relevância está exatamente nessa direcionalidade que emana do texto (e que este estudo pretende captar) e que possui a importância não de restringir a pluralidade de interpretações que podem ser feitas a partir de seus marcos, mas de coibir as conceitualizações e práticas preconceituosas, individualizantes e culpabilizadoras que tem se estabelecido como a produção social dominante a esse respeito.

A lista elaborada pelo PNCFC nos fornece um breve quadro descritivo dos fatores potencializadores da violência dentro da família. Não esquecendo que tal quadro não visa culpabilizá-la pela violência que ocorre em seu interior, já que esta se encontra associada a condições estruturais e históricas da sociedade brasileira, ou seja, a atual tônica das referências para a política pública de convivência familiar permite falar na produção social das violações de direitos das crianças e adolescentes, inclusive da violência intrafamiliar. 
Pode-se perceber ainda que nem todos os fatores listados estão associados à pobreza, remetendo-nos ao fato de que a violência é um fenômeno que acontece em todas as classes sociais.

Ao longo de nossa experiência trabalhando em abrigos, pudemos acompanhar o caso de F., um adolescente abrigado há quatro anos. Quando ele era bebê, seus pais o abandonaram por motivos que permanecessem desconhecidos até hoje. F. foi encaminhado a um abrigo é lá permaneceu alguns anos até ser adotado por um casal que trabalhava como voluntários na instituição. Esse casal possuía uma situação financeira muito boa e F. logo foi inserido na vida normal de um garoto de classe média alta, tendo se adaptado muito bem. No entanto, quando o jovem começou a entrar na adolescência as coisas começaram a mudar. Seu pai passou a tratá-lo mal, chegando muitas vezes a agredi-lo. Obrigava F. a frequentar um psicólogo, apesar do adolescente nunca ter entendido o porquê fora encaminhado a esse profissional. Sua mãe, submissa à autoridade do marido, não se colocava contra as novas atitudes de seu companheiro. A situação chegou a tal ponto que o pai de F. chegou a mantê-lo em cárcere privado, sem poder sair de seu quarto, inclusive para realizar suas refeições e necessidades fisiológicas. Foi quando, pela janela de seu quarto, F. denunciou suas condições de vida a uma vizinha, que reportou os acontecimentos ao Conselho Tutelar.

$\mathrm{O}$ abrigamento de $\mathrm{F}$. foi um escândalo na família e rompeu os fracos vínculos afetivos que ainda ligavam pai e filho. Desde então, a família é totalmente aversiva a qualquer tentativa de reaproximação, tendo o pai sido condenado a pagar uma pensão ao filho por conta de suas atitudes. Como a família sempre teve ótimas condições financeiras, o pai aceitou essa condenação, literalmente, como o preço a pagar para garantir o distanciamento de seu filho. Hoje F. encontra-se conformado de que o abrigo será o seu destino até completar os 18 anos. No entanto, ele não se conformou com o fato de não saber por que fora abrigado. Por que seu pai repentinamente mudou de atitude em relação a ele? Foi necessário um longo período de acompanhamento do adolescente para que a resposta a essa questão começasse a se descortinar. F., conforme ia crescendo, foi demonstrando cada vez mais interesse por pessoas do mesmo sexo. No início, esse desejo não era algo claro nem mesmo para o próprio adolescente. Mas, conforme suas experiências no campo sexual foram amadurecendo, sua homossexualidade foi se afirmando cada vez mais. E F. foi se tornando um rapaz cada vez mais feliz e seguro nesse campo, pois a incerteza parecia que o estava consumindo. Nesse momento, quando sua vida sexual já estava um pouco mais definida, a questão da motivação das violências de seu pai pode ser retomada e compreendida: homofobia. Em conjunto com o jovem, nossa visão a respeito de seu abrigamento foi se construindo em torno do fato de que, 
quando ele entrou na puberdade, provavelmente seu pai percebeu o início de seu interesse por pessoas do mesmo sexo e não pôde suportar isso. Foi a época do encaminhamento ao psicólogo e do começo das agressões. Agora, com um nível de conhecimento a respeito de si mesmo e de sua história, F. encontra-se em paz com o abrigo e capaz de investir em seu futuro.

O caso que acaba de ser descrito ilustra que a violência contra crianças e adolescentes encontra-se alastrada em todas as classes sociais e vincula-se intimamente com nossos preconceitos sociais. O PNCFC se empenha em desmistificar o hábito de se pensar na violação dos direitos de crianças e adolescentes como um fenômeno somente condicionado à classe pobre. Esclarece que, nas décadas de 1960 e 1970, quando começou a se fortalecer no Brasil uma consciência maior sobre a violência doméstica, "os primeiros casos analisados pareciam apontar para fatos isolados cometidos por famílias de baixa renda, por "mães desequilibradas" e "pais alcoólatras" (PNCFC, 2006, p. 57).

As crianças e adolescentes pobres sempre enfrentaram os riscos e as práticas de exclusão e de exploração social. Uma breve visita à história revela crianças e adolescentes na condição de escravos, explorados nas minas auríferas, pequenos marinheiros do século XIX, crianças e adolescentes que trabalhavam jornadas de mais de doze horas diárias nos primórdios da indústria nacional ou que estavam secularmente envolvidos no trabalho rural. Atribuir a pobreza das crianças e adolescentes ou a violação de seus direitos às mudanças ocorridas na estrutura familiar é incorrer em uma séria distorção da história da infância e da adolescência no país. (PNCFC, 2006, p. 53)

Além disso, estudos têm demonstrado que, atualmente, três em cada dez crianças de 0 a 12 anos sofrem algum tipo de violência dentro da própria casa (cf. PNCFC, 2006, p. 57), indicando que o fenômeno é muito mais abrangente do que se pensava e que sua compreensão não pode se contentar com análises individualizantes e culpabilizadoras.

Com isso, pode-se perceber que

[...] a família, lugar de proteção e cuidado, é também lugar de conflito e pode até mesmo ser o espaço da violação de direitos da criança e do adolescente. Nessas situações, medidas de apoio à família devem ser tomadas, bem como outras que se mostrarem necessárias. (PNCFC, 2006, p. 31)

A primeira medida junto a situações de violação de direitos é, sempre, uma intervenção que passa pelo empoderamento da família em questão, ou seja, um apoio (tanto 
social e psicológico como material) no sentido de sua reorganização, sem o afastamento de algum de seus entes.

Contudo, nos casos em que o risco de violência é iminente, ou seja, se a criança ou adolescente permanecer junto com seus responsáveis, poderá sofrer ou continuará a sofrer violência, então outras medidas devem ser tomadas para se evitar a perpetuação da situação.

Dentre essas medidas pode-se destacar o abrigamento. $\mathrm{O}$ abrigo é uma medida de proteção que somente se justifica em face de uma situação de violência iminente e/ou continuada. Assim, do mesmo modo que existe a corresponsabilidade entre a família, o Estado e a sociedade na promoção dos direitos das crianças e adolescentes, também existe uma corresponsabilidade dessas instâncias na violação desses mesmos direitos.

É por isso que, no caso de rupturas dos vínculos familiares, o Estado é que deve se responsabilizar pela proteção das crianças e adolescentes, mesmo porque, na grande maioria dos casos, é possível inferir a existência de uma falha do Estado no adequado suporte a essa família. No entanto, a intervenção estatal não será feita com o intuito de substituir a família no cuidado com seus filhos. Ao contrário, o objetivo deverá ser sempre o desenvolvimento de projetos e estratégias que priorizem o resgate dos vínculos originais ou, em caso de sua impossibilidade, a formação de novos vínculos que garantam o direito à convivência familiar e comunitária. A institucionalização, mesmo nos momentos em que é necessária, não pode perder o foco da reintegração familiar, ou seja, na desinstitucionalização.

Apesar desses avanços, a definição legal não supre a necessidade de compreensão que a variedade dos vínculos familiares exige. Para o PNCFC, "torna-se necessária uma definição mais ampla de "família", com base sócio-antropológica. A família pode ser pensada como um grupo de pessoas que são unidas por laços de consangüinidade, de aliança e de afinidade" (2006, p. 24), ou seja, por obrigações mútuas dadas por vínculos de sangue, vínculos contraídos a partir de contratos (como a união conjugal, por exemplo) e vínculos adquiridos com base no afeto.

A partir dessa realidade, pode-se constatar que muitas pessoas podem ser chamadas de "família". Além da relação de parentesco/filiação, diversas outras relações compõem o que se convencionou chamar de "família extensa", ou seja, uma família que se estende para além da unidade pais/filhos, estando ou não dentro da mesma residência.

“A primeira característica a ressaltar sobre as famílias pobres é sua configuração em rede, contrariando a idéia corrente de que esta se constitui em um núcleo" (SARTI, 2003 apud FÁVERO, VITALE \& BAPTISTA, 2008, p. 17). 
A família não pode ser mais pensada como as pessoas que moram sob o mesmo teto, ou seja, com base no domicílio, mas sim como uma "rede de vínculos". Nesse sentido, os acordos espontâneos (relações de apadrinhamento, amizade e vizinhança), relações que não implicam em obrigações legais, mas que têm um fundo simbólico e afetivo importante, mostram-se muitas vezes mais fortes e relevantes para a sobrevivência e cuidado das crianças e adolescentes do que os laços de sangue ou constituídos juridicamente. Esses vínculos também podem (e devem) ser incorporados no trabalho dos abrigos, não no sentido de obrigação legal para com as crianças e adolescentes abrigadas, mas no de apoio às famílias em situação de vulnerabilidade e cuidados alternativos às crianças e adolescentes afastados do convívio com a família de origem. Para diferenciá-la da "família" e da "família extensa", o PNCFC denomina esse conjunto de relações de "rede social de apoio"39 (2006, p. 24).

O mapeamento e o fortalecimento dessa rede social de apoio é um trabalho essencial a ser levado em consideração pelas equipes técnicas dos abrigos, principalmente a partir da constatação de que as famílias de crianças e adolescentes abrigados tendem a não possuir uma extensa rede familiar (Pereira \& Costa, 2004), o mesmo acontecendo com as chamadas "bases de apoio comunitárias" (cf. PNCFC, 2006. p. 33), tais como professoras das escolas e creches da região, profissionais da rede de saúde ou assistência social, membros de associações de bairro e ONGs que atuam na região etc.

A partir dessa caracterização, pode-se afirmar que a violência intrafamiliar deriva, entre outros fatores, da segregação e do isolamento social dessas famílias. Como um fruto podre dessa "solidão social", é imperativo o desenvolvimento de metodologias que façam um levantamento das redes sociais e bases comunitárias de apoio de cada família e fomente sua inclusão nas modalidades alternativas de ajuda.

É importante destacar, todavia, que, além de potencial para o desenvolvimento da criança, do adolescente e da família, é na utilização dos espaços e instituições sociais e nas relações socialmente estabelecidas que direitos são também violados. Pela própria organização de alguns contextos, as famílias podem estar particularmente expostas a tensões externas que fragilizam seus vínculos, tornando-as mais vulneráveis. (PNCFC, 2006, p. 33)

Do mesmo modo que os vínculos familiares, os vínculos comunitários comportam uma ambivalência para a qual os trabalhadores dos abrigos devem ficar extremamente atentos

\footnotetext{
${ }^{39}$ Neste trabalho adotou-se a seguinte definição conceitual: a "família de origem" é composta tanto pela "família nuclear ou natural" (pai, mãe e irmãos) quanto pela "família extensa" (tios, avós, primos etc.). E a "família substituta" é aquela definida pela guarda, tutela ou adoção.
} 
e cautelosos. Pois, do mesmo modo que tais vínculos podem ser motores de cuidado e proteção, podem ser mobilizadores de situações de violência. E sendo uma das tarefas essenciais dos abrigos a capacidade de resgatar vínculos rompidos, uma das partes mais difíceis do trabalho é, justamente, avaliar quais vínculos devem ser incentivados e quais não.

Ainda, a citação acima nos coloca a questão da relação entre violência intrafamiliar e violência urbana, indicando que, em muitos casos, a segunda pode ser indutora da primeira, o que nos ajuda a compreender mais um dos fatores mobilizadores do fenômeno do nascimento da violência lá onde o senso comum menos esperaria encontrá-la: no interior da família.

\begin{abstract}
A violência, a discriminação, o consumismo veiculado na mídia, a intolerância e a falta de acesso às políticas sociais básicas - aspectos relacionados à própria estruturação da sociedade brasileira - acabam repercutindo sobre a possibilidade de uma convivência familiar e comunitária saudável. (PNCFC, 2006, p. 33)
\end{abstract}

Poder-se-ia acrescentar ainda o tráfico e o consumo de drogas para elencar apenas alguns fatores sociais que possuem um grande poder de refletir sobre as relações intrafamiliares, imprimindo a essas um inalienável caráter político, na medida em que seu fortalecimento depende, entre outros fatores, do investimento do Estado em políticas públicas que venham em seu apoio. $\mathrm{O}$ ambiente familiar afeta e é afetado pelo ambiente social mais amplo.

Para finalizar esse item especialmente dedicado às famílias das crianças e adolescentes abrigados, deseja-se apontar um dado que revela o quanto as questões discutidas nessa parte ainda estão presentes atualmente e o quanto certos preconceitos ainda hoje conseguem manter famílias separadas. Quando perguntadas sobre o que seria necessário para conseguir desabrigar seus filhos, 29\% das famílias entrevistadas por FÁVERO, VITALE \& BAPTISTA (2008) responderam que faltava que o Judiciário acreditasse que a família tinha condições de cuidar de seus filhos (p. 39).

Que fatores estariam presentes nessa dificuldade? A idealização de um modelo de família por parte de quem deve proceder a avaliação e a conseqüente dificuldade de entender diferentes arranjos familiares? A visão de que as famílias pobres são incompetentes para criar sua prole? A idealização de condições materiais para receber as crianças? Ausência de trabalho articulado com a rede de atendimento? Diferentes critérios para abrigar e desabrigar? (FÁVERO, VITALE \& BAPTISTA, 2008, p. 107) 
As famílias percebem que estão submetidas não só ao Judiciário, mas também às próprias instituições de acolhimento, "na medida em que parece haver mais cobrança de um 'esforço individual' por parte das famílias do que um trabalho articulado em rede para apoiálas, em especial no que se refere ao acesso e garantia de seus direitos sociais" (FÁVERO, VITALE \& BAPTISTA, 2008, p. 136). Valorizando o que lhes falta, estabelece-se com elas uma relação de poder na qual as famílias se veem tendo que provar algo que não condiz com a realidade em que vivem. Afinal, não foram os pobres que criaram os critérios do que é ajustado e adaptado. Mas até quando eles terão que provar que se adéquam aos preconceitos sociais para poderem simplesmente existir com dignidade? 


\section{CONSIDERAÇÕES FINAIS}

Parece correto afirmar que, em relação aos abrigos, hoje se vive um momento de transição. Os abrigos não são mais como eram, mas ainda não são como deveriam ser.

No entanto, cabe, neste momento, fazer um balanço do percurso que se traçou. A problemática dos abrigos tem ganhado destaque cada vez maior nos meios de comunicação e também na produção acadêmica, apesar dos estudos ainda serem bastante escassos.

Este trabalho pode concluir que as duas maiores pesquisas quantitativas existentes na área, cuja larga abrangência tornou-se possível pelo vínculo governamental que ambas possuíam, padecem justamente dessa estreita proximidade e dependência do poder público, muitas vezes poupando-o ou sendo com ele condescendente.

Apesar do interesse recente e renovado,

[...] hoje vivemos uma espécie de retórica que guarda relação com o passado, quando se repetia que as crianças só deveriam ser institucionalizadas como último recurso. Não se fala mais de internação de menores abandonados e delinqüentes, mas sim do abrigamento de crianças e adolescentes em situação de risco, também em último caso, respeitando seu direito à convivência familiar e comunitária. (RIZZINI \& RIZZINI, 2004, p. 14)

Pode-se perguntar se houve uma verdadeira mudança ou simplesmente uma troca de palavras? Será que atualmente é muito diferente abrigar do que antes era internar? O avanço chegou a acontecer no plano da realidade propriamente dita ou ainda permanece encarcerado no âmbito do direito? Essas foram as perguntas que se tentou responder ao longo deste trabalho.

As inegáveis conquistas na área jurídica fizeram com que, "na última década, as instituições do tipo internato saíssem de moda e o tema deixou de ser discutido, como se o problema tivesse sido resolvido" (RIZZINI \& RIZZINI, 2004, p. 15). No entanto, este estudo, especialmente os dados apresentados em "Análise da atual política pública de abrigamento no Brasil", aponta para a direção contrária, ou seja, os indicadores são contundentes na apresentação de um quadro de instituições que, apesar dos esforços empreendidos no sentido da transformação de sua modalidade de atendimento, ainda mantêm uma forte relação com o passado dos internatos.

De acordo com o ponto de vista defendido nesta pesquisa, a continuidade do abrigamento por pobreza, principal prática contra a qual o ECA se insurgiu no campo do 
acolhimento institucional, é o maior fator que legitima a afirmação de que o "avanço" idealizado na lei ainda não ocorreu. Obviamente "o fenômeno não se apresenta como nos séculos anteriores, mas suas raízes são facilmente identificáveis no passado, sobretudo no que se refere à mentalidade e à renitência de certas práticas institucionais" (RIZZINI \& RIZZINI, 2004, p. 14), dentre as quais se destaca a utilização das instituições de acolhimento como política de combate à pobreza.

Os altos números de abrigamento por falta de recursos materiais apontam para o fato de que os atuais abrigos continuam sendo utilizados como estratégias de enfrentamento da pobreza, característica que eles herdaram dos antigos internatos como sua maior maldição e, atualmente, sua superação constitui-se um dos seus maiores desafios.

Como se argumentou ao longo do texto, o abrigo utilizado para este fim transforma-se no seu oposto: de uma instituição produtora de igualdade social passa a ser mais uma forma de exclusão dos mais pobres.

Além disso, os números apresentados em nosso estudo, principalmente os 6,6\% de preservação dos vínculos familiares, os $14,1 \%$ de apoio à reestruturação familiar, os 23,8\% de incentivo à convivência com outras famílias e os $57 \%$ de crianças e adolescentes institucionalizados sem perspectiva de desabrigamento (em São Paulo), bem como as fragilidades da rede de proteção social, mostram a persistente imagem dos abrigos como "depósitos de crianças", lugares em que se entra com facilidade, mas de onde se demora muito para sair. Um depósito daquelas crianças e adolescentes que ninguém quer.

No entanto, o que preocupa ainda mais ao analisar os dados apresentados é que os abrigos analisados pelo Levantamento Nacional podem ser considerados acima da média nacional, pois

[...] a escolha das instituições beneficiadas pela Rede SAC confere determinada característica aos resultados da pesquisa: os abrigos encontrados contidos nesse universo tendem a ter uma situação relativamente melhor do que a média dos abrigos no Brasil. Isso porque a inclusão na Rede SAC traz implícita, ao menos teoricamente, a necessidade de as entidades estarem registradas, no mínimo, nos Conselhos Municipais de Direitos da Criança e do Adolescente, que têm a prerrogativa de fiscalizar as entidades que prestam serviços a crianças e adolescentes nos municípios onde estão instaladas. (SILVA \& MELLO, 2003, p. 35)

Pode-se depreender do exposto que a situação real dos abrigos no Brasil é ainda pior do que a encontrada na pesquisa do IPEA. 
Diante desse quadro, poder-se-ia arriscar a perguntar se, enquanto peças da rede de proteção, os abrigos seriam realmente necessários. Faz sentido existirem abrigos? Com base neste estudo, pensa-se que a resposta a essa pergunta poderia ser afirmativa, desde que se leve em conta alguns condicionantes.

Viu-se que os abrigos são instituições essenciais dentro do sistema de proteção, pois atendem determinados tipos de casos que nenhuma outra instituição atende. No entanto, é fato que o acolhimento institucional é atualmente utilizado em uma escala muito maior do que a necessária, não sendo a melhor alternativa para muitas famílias atendidas por seus serviços e que, com o incentivo correto, poderiam superar suas dificuldades sem a necessidade de separação de seus membros. Em outras palavras, os abrigamentos indevidos ou inadequados constituem um dos grandes problemas da rede de acolhimento institucional o que, como se expôs anteriormente, revela ainda uma profunda incompreensão da função social do abrigo.

Seguindo a linha de pensamento dos abrigamentos que poderiam ser evitados, tentouse também destacar neste trabalho as iniciativas necessárias à prevenção da institucionalização. No entanto, percebeu-se que, na maioria das vezes, essas iniciativas extrapolam o alcance daqueles que se debruçam sobre a questão específica do acolhimento institucional, pois são da ordem de uma transformação muito mais ampla da sociedade, envolvendo o desenvolvimento mais efetivo das políticas de educação, saúde, trabalho e renda, habitação etc. Quando uma criança ou adolescente é abrigado, isso é sintoma de que todas as políticas sociais básicas falharam. Os abrigos são os reflexos do fracasso da sociedade como um todo. Eles são a consequência necessária de uma sociedade desigual e produtora de violência.

Para a pergunta sobre se os abrigos são de fato necessários no interior do sistema de proteção, a resposta poderia caminhar no seguinte sentido: eles são necessários desde que funcionem bem. E, para funcionarem bem, necessitam, além do desenvolvimento do atual estágio de suas políticas específicas, do apoio das políticas sociais básicas. Se os abrigos funcionarem mal ou forem mal utilizados, transformam-se em meros agentes de exclusão social.

Desse modo, caso funcionasse efetivamente um programa forte de apoio familiar, com vistas à prevenção da institucionalização, esperar-se-ia que as instituições de acolhimento continuassem a ser necessárias, mas em número bem menor dão que o atual e somente para os casos mais extremos.

Nesse sentido, esta pesquisa pode apontar que ainda existe um pensamento naturalizado na sociedade e especialmente na política de proteção às crianças e aos 
adolescentes vítimas de violência que iguala "necessidade de proteção" a “institucionalização". No entanto, proteger deve ser diferente de "separar pais e filhos".

Essa conclusão fica clara quando nos lembramos das discussões feitas a respeito, por exemplo, da regionalização do atendimento. Crianças e adolescentes são abrigados em locais distantes de seus familiares, mesmo existindo instituições que poderiam acolhê-los próximos aos seus contextos de origem. O resultado desse processo de desenraizamento no qual se transforma o abrigamento é que "proteger" atualmente ainda é simplesmente afastar da família. E isso pode ser concluído não apenas baseado nos dados da regionalização, mas também nos baixos índices de reintegração familiar. Em relação aos internatos, o campo no qual os abrigos mais avançaram foi o dos cuidados que são oferecidos à criança e ao adolescente no interior dessas instituições. Mas, a perspectiva de institucionalização ainda não foi vencida, pois pouco se progrediu no trabalho que se consegue realizar com as famílias para que elas possam novamente acolher seus filhos.

A partir desta pesquisa é possível extrair-se ainda outros elementos para compor o conceito socialmente construído de proteção a crianças e a adolescentes.

Inicialmente, os dados históricos levantados em "Breve histórico dos abrigos no Brasil" apontam para a questão da criminalização do abandono, consubstanciado em torno da noção de "menor". Como o abandonado é visto como potencialmente perigoso, um possível delinquente no futuro, os modos de protegê-lo se confundiram com os designados à punição daqueles que a sociedade temia que ele se transformasse. Desse modo, o modelo prisional se tornou o parâmetro das instituições destinadas à "proteção" de crianças e adolescentes carentes, abandonados e órfãos.

Além disso, as discussões feitas a respeito do isolamento do abrigo e da falta de apoio das demais políticas sociais básicas conduzem à conclusão de que, na melhor das hipóteses, tais instituições somente serão capazes de proteger a criança ou o adolescente de maneira individualizada, ou seja, garantindo os direitos daqueles que estão diretamente sob sua responsabilidade e relegando suas famílias à própria sorte. A insuficiência e a desarticulação da rede de proteção como um todo gera um sistema que protege descontextualizadamente, com foco apenas nas crianças e adolescentes e não em seu núcleo familiar. Será que isso é mesmo proteger?

Ainda, os números que indicam uma presença muito maior de crianças abrigadas do que de adolescentes também são importantes no desenho atual do conceito de proteção. Esse fato pode ser um indício de que o imaginário social concebe os adolescentes como menos "merecedores" de proteção. Na realidade, no que concerne à ambiguidade que estamos 
trabalhando entre proteção-punição, em relação a essa faixa etária, a sociedade parece construir mecanismos coercitivos menos sofisticados do que em relação às crianças, jogando com essas polaridades conforme lhe interessa: para punir, o adolescente é muitas vezes tratado como adulto. Vale lembrar aqui a defesa que amplos setores da sociedade fazem da redução da maioridade penal. No entanto, em outros âmbitos da vida, como o da sexualidade, por exemplo, muitos querem tratá-lo como uma criança.

Retomando a essência do conceito, quando separamos pais e filhos, o mais grave é que isso é feito sem a certeza de que se conseguirá reunir novamente essa família. Já se ressaltou que o Levantamento Nacional chegou ao índice de apenas 14,1\% para os abrigos que estão adequados na questão do apoio à reestruturação familiar. Gostar-se-ia de ir mais longe e apontar que, do ponto de vista deste estudo, o trabalho psicossocial com as famílias de crianças e adolescentes abrigados é o grande buraco metodológico nos abrigos hoje no Brasil, sendo, inclusive, nesta lacuna que o trabalho do psicólogo poderia ser melhor pensado e aproveitado como parte do plano de atendimento institucional dos abrigos.

As pesquisas e os documentos oficiais que foram analisados centram-se nos motivos que levaram tais famílias a tornarem-se violentas, apontando as privações de ordem material como os principais fatores na constituição de tal fenômeno e, no entanto, calam-se quando o assunto é a reprodução da violência no interior da dinâmica familiar e nos seus modos possíveis de enfrentamento. Percebeu-se, a partir do estudo das três pesquisas analisadas em detalhes neste trabalho, que todas elas evitam tratar com mais profundidade o tema das famílias de crianças e adolescentes abrigados com famílias violentas, restringindo-se a focalizar a falta de condições materiais e de apoio estatal a que estão submetidas, como se a questão da violência intrafamiliar pudesse ser satisfatoriamente resumida e compreendida a partir desse marco conceitual.

A análise da política pública de acolhimento institucional revelou a necessidade de conhecer o íntimo dessas famílias e estudar o processo de transformação da desigualdade social em violência contra suas crianças e adolescentes. Esse conhecimento será absolutamente necessário para a transformação dessa mesma política pública que apregoa conhecer a realidade dessas famílias, mas, de fato, conhece-a muito pouco, às vezes até resvalando, não para o seu conhecimento, mas sim para sua idealização. Como uma das conclusões que emanam desta pesquisa, é preciso superar a concepção de que falar de famílias violentas leva necessariamente a um discurso culpabilizador sobre as mesmas. Na realidade, com medo de culpabilizá-las, individualizando questões de ordem social, o necessário combate ao ponto de vista que vê as famílias pobres como incapazes, muitas vezes 
transforma-se em seu oposto, ou seja, em sua idealização. Contudo, quando isso acontece, essas famílias continuam invisíveis.

Por fim, talvez estejamos prontos para responder, afinal, o que é um abrigamento? Quando ele é necessário?

Dissemos em nosso trabalho que

[...] para haver abrigamento, é preciso que haja violência. É claro que a pobreza em si mesma pode ser considerada uma violência: uma violência da sociedade em geral contra o pobre. Mas é uma violência que não justifica outra violência: a do próprio abrigamento. Na realidade, abrigar, na medida em que é separar uma família, é sempre um ato violento. Mas é uma violência necessária em alguns casos. É por isso que, mesmo quando ela é necessária, deve ser excepcional e provisória. O abrigamento é, na verdade, um cálculo de violências.

É justamente no cálculo que se faz em torno da necessidade de se cometer uma violência para barrar outra que o abrigamento pode encontrar sua justificativa e sua legitimidade.

As ideias de "violência necessária" e "cálculo de violências" são as que estão na base da justificação ética da própria existência de instituições, como os abrigos. Mas como é possível uma violência ser necessária? A violência não é algo intrinsecamente ruim? Não é sempre um mal a ser combatido? E como é possível "calcular" em cima da violência, ou seja, o que dá legitimidade a essa espécie de "medida" ou avaliação que se faz em torno do que é mais ou menos violento para o outro?

A violência do abrigamento somente pode se tornar "necessária" quando é utilizada para interromper a repetição de outras violências consideradas mais graves e prejudiciais à vítima. Justamente por isso, o abrigamento possui um caráter revitimizador inerente a ele. Assim, se o abrigo não for capaz de realizar um trabalho intensivo que se coloque para além da simples separação física, a "violência necessária" transforma-se em mera punição.

Nas discussões sobre educação infantil, há anos se combate a ideia da creche como "mal necessário", uma vez que a mãe tem que sair para trabalhar. Esse combate se dá no sentido de que a creche pode ser muito boa para a criança, sendo interpretada como um direito seu. No caso do abrigamento fica a pergunta: será o abrigo um "mal necessário"?

Este estudo considera que não, pelos mesmos motivos acima expostos em relação às creches: o abrigamento pode ser algo extremamente benéfico na vida de uma criança ou adolescente violentado e, nesse sentido, constitui-se como seu direito. No entanto, isso não retira a ambiguidade inerente a esse serviço, qual seja, o de que o abrigamento, por mais 
necessário e benéfico que possa ser para uma criança ou adolescente em determinado momento, será sempre uma revitimização.

Obviamente, a ideia do abrigamento como um "cálculo de violências" não é incompatível com o fato de que, em muitos casos, o abrigo é um lugar extremamente positivo para a criança (poderia contar o caso do M. que, apesar de ter melhorado muito no abrigo, ainda tem a mãe como uma referência importante). Quero, no entanto, salientar que, mesmo nos casos em que o abrigamento se faz absolutamente necessário, ainda assim, permanece uma violência latente, pois mesmo uma família agressora continua sendo a principal referência emocional da criança abrigada. Por mais que se proceda a uma ruptura de vínculos violentos que, muitas vezes, são vivenciados imediatamente com alívio e felicidade por parte do abrigado, não se deixa de romper relações que constituíam referências essenciais na vida dessas crianças. Abrigar é sempre um ato carregado de ambivalências e contradições.

\subsection{Indicativos para a política pública de proteção à criança e adolescente vítima de violência: apontamentos para próximas pesquisas}

As conclusões a que chegamos indicaram a necessidade de se estudar e de se estabelecer uma metodologia de trabalho psicossocial com famílias agressoras, tema que mereceria um estudo posterior. Além desse projeto, gostar-se-ia de dedicar as próximas páginas ao esboço de outro projeto a ele intimamente relacionado e, talvez, até mesmo, complementar.

Ao longo desta pesquisa, colecionou-se uma série de argumentos que depõem contra a institucionalização de crianças e adolescentes vítimas de violência. Ao final desta análise da política pública de abrigamento, percebe-se que, apesar dos muitos avanços, esse modelo ainda não conseguiu realizar os objetivos a que se propôs. Mas, então, como proteger esses meninos e meninas?

Pretende-se dedicar esse último trecho deste trabalho ao objetivo de avaliar, uma vez diagnosticado que os abrigos ainda estão muito distantes do que se poderia conceber como atendimento ideal, se, pelo menos, a política caminha no rumo certo.

Ao longo de todo o trabalho, o conceito de proteção forneceu uma unidade conceitual que costurou a diversidade de temas abordados. Pôde-se perceber que, em muitos pontos, a 
proteção integral encontrou limites e barreiras. Contudo, acredita-se que a maioria das deficiências apontadas não são intrínsecas aos abrigos, ou seja, elas podem ser superadas.

No entanto, quando se identifica que os abrigos trabalham com a ideia de separar para proteger, essa ideia possui um peso diferenciado em relação às demais, pois ela faz parte da essência desse sistema de atendimento. Superá-la acarretaria a superação do próprio modo de atendimento em abrigos.

Obviamente é possível se pensar em situações nas quais separar seja, de fato, um ato de proteção. No entanto, considera-se que, atualmente, o "separar para proteger" é usado indiscriminadamente em casos para os quais essa não seria uma boa alternativa.

Os avanços históricos mostram que, pelo menos em parte, o rumo adotado até o momento tem tido alguns efeitos positivos. No entanto, consideramos que esse modelo, tal como está constituído atualmente, tem um limite, pois está irremediavelmente ligado ao "separar para proteger". E, sob o ponto de vista deste trabalho, essa vinculação coloca o limite do modelo em um grau muito aquém do necessário, ou seja, em um nível inferior ao que é requisitado por sua demanda.

Contudo, estamos diante de outro obstáculo, que é a falta de alternativas ao abrigamento para os casos que, atualmente, são considerados como os que demandam acolhimento institucional.

Nesse sentido, pensamos que o desafio que se coloca atualmente é elaborar estratégias no campo da prevenção ao abrigamento, mesmo depois que a violência já se instaurou na dinâmica familiar. O que é possível fazer para proteger as crianças e os adolescentes vítimas de violência grave, ${ }^{40}$ sem revitimizá-las com a institucionalização?

Já foi visto que o pressuposto do trabalho dos abrigos está na separação da família como forma elementar de proteção. Tal separação pode realmente ser necessária nos casos mais graves, em que a permanência da criança ou adolescente no núcleo familiar representaria a possibilidade de uma violência iminente. No entanto, será que ela era necessária para todos os casos que estão nos abrigos atualmente? Será que a separação é a única forma de proteção a ser empregada nesses casos? Desse modo, o desafio apontado logo acima, de se pensar em mecanismos de prevenção ao abrigamento, mesmo depois que a violência já ocorreu, pode ser

\footnotetext{
${ }^{40}$ O adjetivo "grave" serve para a diferenciação desses casos daqueles que costumam ser encaminhados aos CREAS (Centros de Referência Especializados de Assistência Social), que também atuam no atendimento a crianças e adolescentes vítimas de violência, quando o caso não demanda separação da vítima do ambiente familiar. A crítica que se coloca é que, atualmente, considera-se como casos que demandam separação familiar situações que não necessitariam dessa separação se pudesse se dispor de um outro modelo de atendimento a esses casos.
} 
redefinido como o desafio de pensar em mecanismos protetivos que não lancem mão da separação familiar como forma de proteção.

Partindo desse princípio, pensamos que investir na família de origem é que deve ser a primeira modalidade de proteção, mesmo nos casos de violência. Esse é o início do caminho para uma nova política de proteção às crianças e aos adolescentes vítimas de violência grave, que teria a seguinte lógica: uma vez detectado um caso de criança ou adolescente vítima de violência grave, ${ }^{41}$ a primeira intervenção seria o encaminhamento a um programa intensivo de apoio à família de origem. Somente quando esse programa falhasse ou o caso fosse grave demais para se arriscar a permanência da criança ou adolescente no núcleo familiar é que seria feito o encaminhamento às famílias acolhedoras ou abrigos. Esta é uma aposta que, para a grande maioria dos casos que atualmente consideramos como demandas de abrigamento, é $o$ incentivo à união e não à separação dessa família, que vai melhor combater a violência que se instaurou em seu interior.

A sociedade brasileira não pode mais continuar reproduzindo e financiando ações que reforçam o abandono e a segmentação entre crianças, adolescentes e suas famílias nessa forma de atendimento. $\mathrm{O}$ alto custo despendido pelo Poder Público com abrigamento de crianças e adolescentes não toca a raiz da questão e a ineficiência desse programa para a grande maioria dos seus usuários pode ser medida pelo longo tempo de abrigamento, pela baixa escolaridade daqueles que estão prestes a atingir a maioridade e pela falta de perspectiva de desabrigamento, conforme os índices apontados na pesquisa. (AASPTJ-SP/NCA-PUCSP/SAS/FUNDAÇÃO ORSA, 2003, p. 225)

Em nossa opinião, falta a essa política uma metodologia de intervenção com as famílias que verdadeiramente dê conta de suas necessidades, não somente no campo material, mas também e principalmente no campo de sua psicodinâmica.

O ponto central a ser questionado é o fato do trabalho psicossocial proposto pelos abrigos ainda ser muito tributário da noção de "atendimento", entendido como o encontro de um técnico (normalmente psicólogo ou assistente social) em um espaço fechado e artificial, para uma conversa de curta duração.

Esse modelo se afasta do cotidiano dessas famílias e tem se constituído em um lugar de poder dos técnicos, engendrado como um mecanismo de defesa frente a esse mesmo cotidiano que se quer transformar. O cotidiano dessas famílias é assustador e o espaço simbólico do "atendimento" é o lugar de segurança do técnico.

\footnotetext{
${ }^{41}$ Com exceção dos casos em que a criança ou adolescente corre realmente risco de vida ou ainda casos de violência sexual, por exemplo, nos quais a convivência com o agressor pode ser altamente prejudicial para a vítima.
} 
As famílias pobres funcionam em um registro comunitário, muitas vezes, totalmente opaco para os técnicos oriundos das classes médias, atendendo em seus ambientes protegidos. Fala-se que o ambiente fechado possibilita o sigilo e promove um meio facilitador da expressão de conteúdos difíceis de serem falados em outros espaços. No entanto, cabe perguntar: o ambiente fechado protege a quem? $\mathrm{O}$ atendido ou o técnico? $\mathrm{E}$ ainda: esse modelo centrado na ideia de "atendimento" não é oriundo de práticas que seguem o modelo clínico, construído para atingir objetivos diferentes daqueles do trabalho social? Não perguntamos se esse modelo faz sentido quando a proposta é trabalhar com as classes mais pauperizadas?

Por isso, acredita-se que uma reformulação na metodologia de trabalho com essas famílias deve ter o educador social como seu elemento central. Trabalhando com contextos informais, a intervenção desse profissional rompe com a lógica do “atendimento". É uma intervenção que não se afasta do cotidiano. Ao contrário, nutre-se dele.

Assim, a proposta que se coloca é a de transformar o cotidiano dessas famílias a partir de seu interior, ou seja, a partir da experiência advinda das vivências conjuntas desse profissional com seus atendidos. Seu objetivo é, por meio de sua presença no cotidiano de uma família violenta, proteger a criança ou adolescente ao mesmo tempo em que trabalha para tornar possível a convivência não-violenta que antes de sua intervenção era impossível. Tratase de sustentar, no cotidiano e por meio de sua presença, uma proteção que não separe a família.

Somente o trabalho no cotidiano dessas famílias tem a intensidade necessária para efetivamente romper com o ciclo de violência instaurado em seu interior. As propostas baseadas em atendimentos, mesmo que frequentes, não conseguem ser tão intensivas, nem tão comunitárias quanto os casos que atualmente consideramos como casos de abrigamento demandam.

Uma metáfora que se poderia criar para exemplificar a proposta que está sendo feita vem da figura do acompanhante terapêutico (AT). Na área da saúde mental, percebeu-se que o acesso e o desenvolvimento dos trabalhos com certos pacientes fluíam melhor se o terapeuta abrisse mão da formalidade de seu consultório e fizesse suas intervenções enquanto acompanhava seu paciente em alguma atividade cotidiana. Sugere-se para o trabalho do educador social é que ele seja entendido como um acompanhante terapêutico da área social ou um "AT social".

Ao longo desta pesquisa, pôde-se perceber a existência de três demandas muito diferentes dentro dos abrigos, cada uma delas exigindo um foco diferenciado de trabalho: 1) 
as crianças e adolescentes que possuem família; 2) as que não possuem família, mas têm chances de serem adotadas e; 3 ) as que não possuem família e também não têm chances de serem adotadas.

Para a primeira dessas demandas, todos os esforços recaem sobre o trabalho intensivo de reintegração familiar. Para a segunda, o foco do trabalho passa a ser os investimentos em famílias substitutas. E no terceiro caso, o objetivo primordial é a preparação para a autonomia

Não se deve deixar iludir que os incentivos para programas de guarda familiar ou adoção, embora necessários, vão resolver o problema das crianças e adolescentes institucionalizados, pois, como esclarecido, "tais ações voltam-se a segmentos específicos, não atingindo a maior parte dessa população" (AASPTJ-SP/NCA-PUCSP/SAS/FUNDAÇÃO ORSA, 2003, p. 225). É somente para a segunda demanda identificada que se aplicam os esforços no sentido de adoção, pois investir em famílias substitutas para quem possui família de origem é, muitas vezes, desvalorizar a capacidade da família de origem de cuidar de seus filhos.

De acordo com as pesquisas, a maioria das crianças e adolescentes que se encontram atualmente nos abrigos pertencem à primeira demanda identificada e seria preferencialmente para eles que o novo modelo de atendimento que sugerimos acima se aplicaria.

Nesse sentido, as instituições de acolhimento seriam em larga medida espaços mais direcionados para a terceira demanda apontada, pois "para aqueles que não têm família e tampouco a possibilidade de serem adotados, o abrigo torna-se um espaço de referência e pertencimento ainda mais significativo" (AASPTJ-SP/NCA-PUCSP/SAS/Fundação Orsa, 2003, p. 225).

Em resumo, tais sugestões partem do pressuposto de que a rede de proteção deveria estimular e possuir uma oferta diferenciada de modalidades de atendimento, pois as necessidades das crianças e adolescentes também são heterogêneas. São as políticas públicas que devem se adequar às necessidades da população e não o inverso. 


\section{REFERÊNCIAS BIBLIOGRÁFICAS}

AASPTJ-SP/NCA-PUCSP/SAS/FUNDAÇÃO ORSA. Por uma política de abrigos em defesa de direitos das crianças e dos adolescentes na cidade de São Paulo: motivos de demanda e qualidade de oferta de serviços de atenção à criança e adolescente sob medida de proteção “abrigo". São Paulo: 2003.

AQUINO, L. M. C. A rede de proteção a crianças e adolescentes, a medida protetora de abrigo e o direito à convivência familiar e comunitária: a experiência em nove municípios brasileiros. In: IPEA. Levantamento Nacional de Abrigos para Crianças e Adolescentes da Rede SAC. Brasília: 2003, p. 325.

AZEVEDO, M. A. \& GUERRA, V. N. A. Infância e violência intrafamiliar. Apud TERRA DOS HOMENS. Série em defesa da convivência familiar e comunitária. Violência Intrafamiliar. Rio de Janeiro: ABTH, v. 4, 2003.

BEGHIN, N. \& PELIANO, A. M. T. M. O voluntariado nos abrigos: uma profissão de fé. In: IPEA. Levantamento Nacional de Abrigos para Crianças e Adolescentes da Rede SAC. Brasília: 2003, p. 243.

BRASIL, Lei 8.069/90. Dispõe sobre o Estatuto da Criança e do Adolescente. Disponível em: <http://www.planalto.gov.br/ccivil_03/Leis/L8069.htm>. Acesso em: 11 jun. 2009.

BRASIL, Plano Nacional de Promoção, Proteção e Defesa do Direito de Crianças e Adolescentes à Convivência Familiar e Comunitária (PNCFC). Brasília: 2006.

CARREIRÃO, U. L. Modalidades de abrigo e a busca pelo direito à convivência familiar e comunitária. In: IPEA. Levantamento Nacional de Abrigos para Crianças e Adolescentes da Rede SAC. Brasília: 2003, p. 303.

CBIA/SP \& IEE/PUC-SP. Trabalhando abrigos. Cadernos de Ação no 3, São Paulo: 1993.

CONSELHO MUNICIPAL DOS DIREITOS DA CRIANÇA E DO ADOLESCENTE (RJ). Política de abrigo para crianças e adolescentes do município do Rio de Janeiro. Rio de Janeiro, setembro de 2001.

CONSELHO MUNICIPAL DOS DIREITOS DA CRIANÇA E DO ADOLESCENTE (SP). Resolução 053/99. 
CONSELHO NACIONAL DOS DIREITOS DA CRIANÇA E DO ADOLESCENTE \& CONSELHO NACIONAL DE ASSISTÊNCIA SOCIAL. Orientações Técnicas para os Serviços de Acolhimento para Crianças e Adolescentes. Brasília: fev. 2008.

CUNHA, A. C. O dia seguinte: a vida além dos muros de adolescentes egressos do programa Casas de Convivência - FEBEM/DT2. Dissertação de Mestrado em Serviço Social, PUC/SP, 1999.

FÁVERO, E. T. O que é o Plano Nacional de Promoção, Proteção e Defesa do Direito de Crianças e Adolescentes à Convivência Familiar e Comunitária (PNCFC), Revista Serviços Social e Sociedade, São Paulo: Cortez, nº 91, ano XXVIII, setembro de 2007.

FÁVERO, E. T., VITALE, M. A. F. \& BAPTISTA, M. V. Famílias de crianças e adolescentes abrigados: quem são, como vivem, o que pensam, o que desejam. São Paulo: Paulus, 2008.

GARCIA MENDEZ, E. \& COSTA, A. C. G. Das necessidades aos direitos. São Paulo: Malheiros, 1994.

GOFFMAN, I. Manicômios, prisões e conventos. São Paulo: Perspectiva, 1974.

IPEA. Levantamento nacional de abrigos para crianças e adolescentes da Rede SAC. Brasília: 2003.

LIMA, A. S. Patronato de menores. Rio de Janeiro: Henrique Velho, 1942.

MARICONDI, M. A. Falando de abrigo. Cinco anos de experiência em projeto Casas de Convivência. São Paulo: Febem, 1997.

MELLO, S. G. O ambiente físico no qual vivem crianças e adolescentes em situação de abrigo. In: IPEA. Levantamento Nacional de Abrigos para Crianças e Adolescentes da Rede SAC. Brasília: 2003, p. 135.

MELLO, S. G. \& SILVA, E. R. A. Quem cuida? O quadro de recursos humanos nos abrigos. In: IPEA. Levantamento Nacional de Abrigos para Crianças e Adolescentes da Rede SAC. Brasília: 2003, p. 99. ordenamento e financiamento dos serviços de abrigo. Brasília: 2000. 
MESGRAVES, L. A Assistência à infância desamparada e a Santa Casa de São Paulo: a Roda dos Expostos do século XIX. Revista de História, v. III, nº 103, p. 401-23, jul./set., 1976.

NOB-RH/SUAS. MINISTÉRIO DO DESENVOLVIMENTO SOCIAL E COMBATE À FOME. Norma Operacional Básica de Recursos Humanos do SUAS (NOB-RH/SUAS). Brasília: 2006.

ORGANIZAÇÃO PANAMERICANA DE SAÚDE. Documento de posición de la OPS sobre políticas de salud em la vivienda. OMS/OPS/Divisão de Saúde e Meio Ambiente.

Washington, D. C.; Havana, Cuba, 1999.

OLIVEIRA, R. C. S. (Coord.) Quero voltar para casa: o trabalho em rede e a garantia do direito à convivência familiar e comunitária para crianças e adolescentes que vivem em abrigos. São Paulo: AASPTJ-SP, 2007.

OLIVEIRA, S. D. O Judiciário e a medida de abrigo no âmbito da proteção integral: a experiência do Rio de Janeiro. In: IPEA. Levantamento Nacional de Abrigos para Crianças e Adolescentes da Rede SAC. Brasília: 2003, p. 367.

PASSETTI, E. Crianças carentes e políticas públicas. In: DEL PRIORE, M. (Org.) História das crianças no Brasil. São Paulo: Contexto, 2008, p. 347-375.

PEREIRA, J. M. F. \& COSTA, L. F. O ciclo recursivo do abandono, 2004. Disponível em: <http://www.psicologia.com.pt/artigos/ver_artigos.php?codigo=A0207\&area=d4\&subarea >. Acesso em: 22 out. de 2009.

PNCFC - PLANO NACIONAL DE PROMOÇÃO, PROTEÇÃO E DEFESA DO DIREITO DE CRIANÇAS E ADOLESCENTES À CONVIVÊNCIA FAMILIAR E COMUNITÁRIA. Disponível em: <http://www.mds.gov.br/cnas/conteudo-tematico/relatorios/pncfc-28-122006.doc/view>. Acesso em: 23 set. 2009.

RIZZINI, I. Assistência à infância no Brasil: uma análise de sua construção. Rio de Janeiro: Universitária Santa Úrsula, 1993.

RIZZINI, I. \& PILOTTI, F. (Org.). A arte de governar crianças: história das políticas sociais, da legislação e da assistência à infância no Brasil. Rio de Janeiro: INN/EDUSU/Amais, 1995. 
RIZZINI, I. \& RIZZINI, I. A institucionalização de crianças no Brasil: percurso histórico e desafios do presente. São Paulo: Loyola, 2004.

RIZZINI, I. \& WIIK, F. B. O que o Rio tem feito por suas crianças? Um estudo sobre a ação dirigida à infância pobre no Município do Rio de Janeiro. Rio de Janeiro: A4mãos, 1990.

SADEK, M. T. \& ARANTES, R. B. A crise do Judiciário e a visão dos juízes. In: Dossiê Judiciário/Revista USP, no 21. São Paulo: CCS/USP, 1994.

SÃO PAULO. Levantamento da medida de proteção abrigo nas VIJs da Capital. São Paulo: Corregedoria Geral da Justiça, 2003.

SARTI, C. A família como espelho: um estudo sobre a moral dos pobres. Campinas: Associados, 1996.

SILVA, E. R. A. O financiamento dos abrigos para crianças e adolescentes no Brasil. In: IPEA. Levantamento Nacional de Abrigos para Crianças e Adolescentes da Rede SAC. Brasília: 2003, p. 169.

O Estatuto da Criança e do Adolescente e a percepção das instituições de abrigo. In: IPEA. Levantamento Nacional de Abrigos para Crianças e Adolescentes da Rede SAC. Brasília: 2003, p. 195.

A construção do direito à convivência familiar e comunitária no Brasil. In: IPEA. Levantamento Nacional de Abrigos para Crianças e Adolescentes da Rede SAC. Brasília: 2003, p. 287.

Os filhos do governo: a formação da identidade criminosa em crianças órfãs e abandonadas. São Paulo: Ática, 1997.

SILVA, E. R. A. \& MELLO, S. G. Contextualizando o Levantamento Nacional dos Abrigos para Crianças e Adolescentes da Rede de Serviços de Ação Continuada. In: PEA.

Levantamento Nacional de Abrigos para Crianças e Adolescentes da Rede SAC. Brasília: 2003, p. 21.

Um retrato dos abrigos para crianças e adolescentes da Rede SAC: características institucionais, forma de organização e serviços ofertados. In: IPEA. Levantamento Nacional de Abrigos para Crianças e Adolescentes da Rede SAC. Brasília: 2003, p. 71. 
SILVEIRA, A. M. Particularidades da adoção: a questão da etnia. Dissertação de Mestrado. São Paulo: Pontifícia Universidade Católica de São Paulo, 2002.

VICENTE, C. M. Abrigos: desafios e perspectivas. Boletim "Uma família para uma criança”, ABTH n 12/13. 